\title{
EभKEMECEUपHBUИ НАУЧНО-ТЕХНИЧЕСКИЙ
} И ПРОИЗВОДСТВЕННО-ЭКОНОМИЧЕСКИЙ ҮКУРНАА
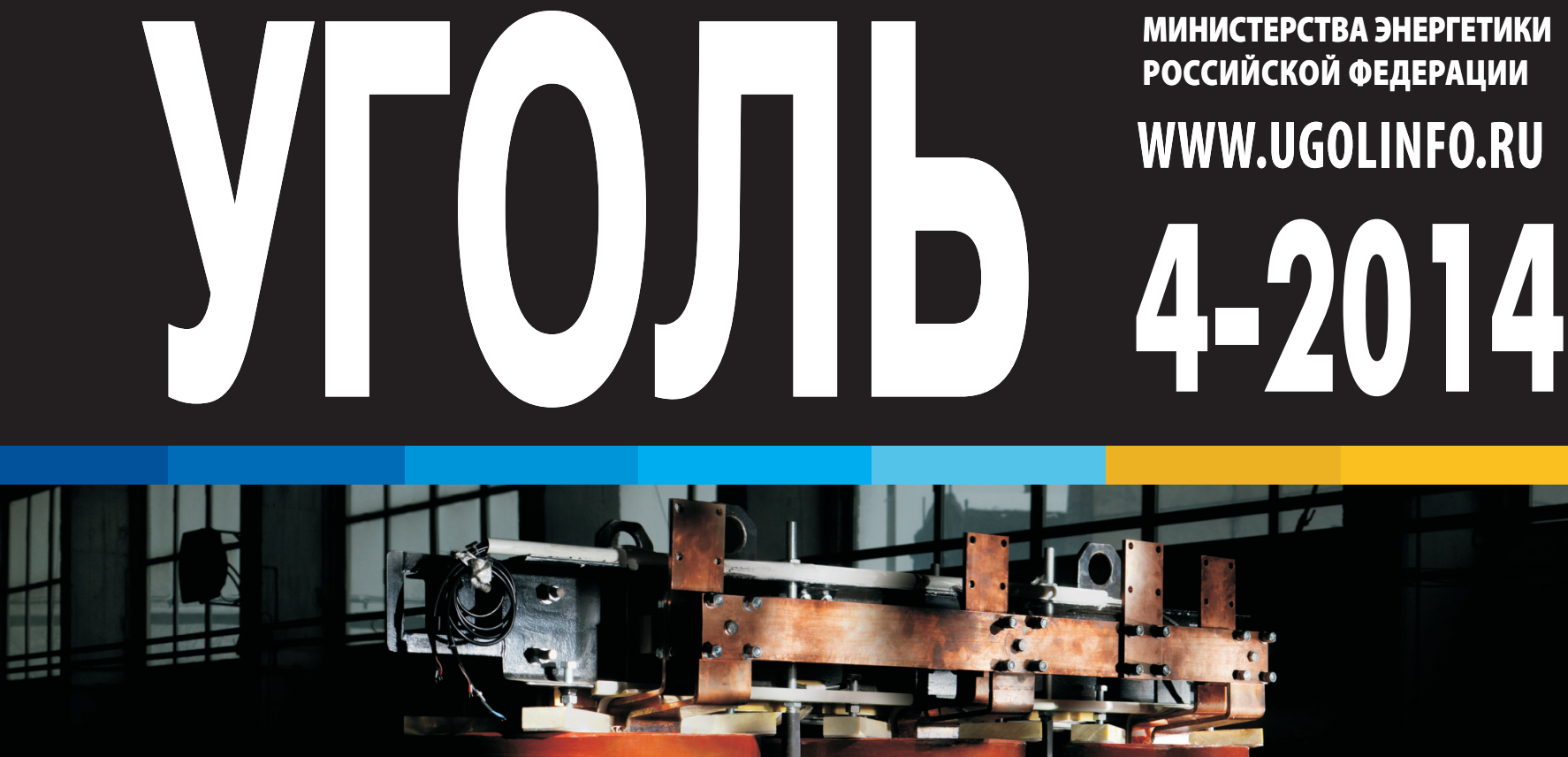

\section{ENERGY \\ COMPONE}

СУХИЕ TРАНСФОРМАТОРЫ TC-RESIN GLASS FIBER

\section{ИННОВАЦИОННЫЕ ТЕХНОЛОГИИ В ЭНЕРГЕТИКЕ}

ПРОИЗВОДСТВО СИЛОВОГО ЭЛЕКТРООБОРУДОВАНИЯ

МОДЕЛИРОВАНИЕ И ВНЕДРЕНИЕ КОМПЛЕКСНЫХ СИСТЕМ ЭНЕРГОСНАБЖЕНИЯ

ПРОЕКТИРОВАНИЕ И СТРОИТЕЛЬСТВО ПРОМЫШЛЕННЫХ И ГРАЖДАНСКИХ ОБЪЕКТОВ 


\section{СОВРЕМЕННЫЕ ТЕХНОЛОГИИ УПРАВЛЕНИЯ ПРОЦЕССАМИ ДОБЫЧИ УГЛЯ}

Приглашаем Вас посетить наш стенд FG42 на выставке

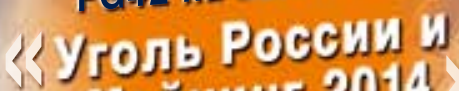

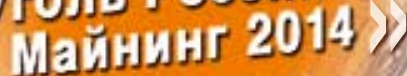
c 3 по 6 июня 2014 r.
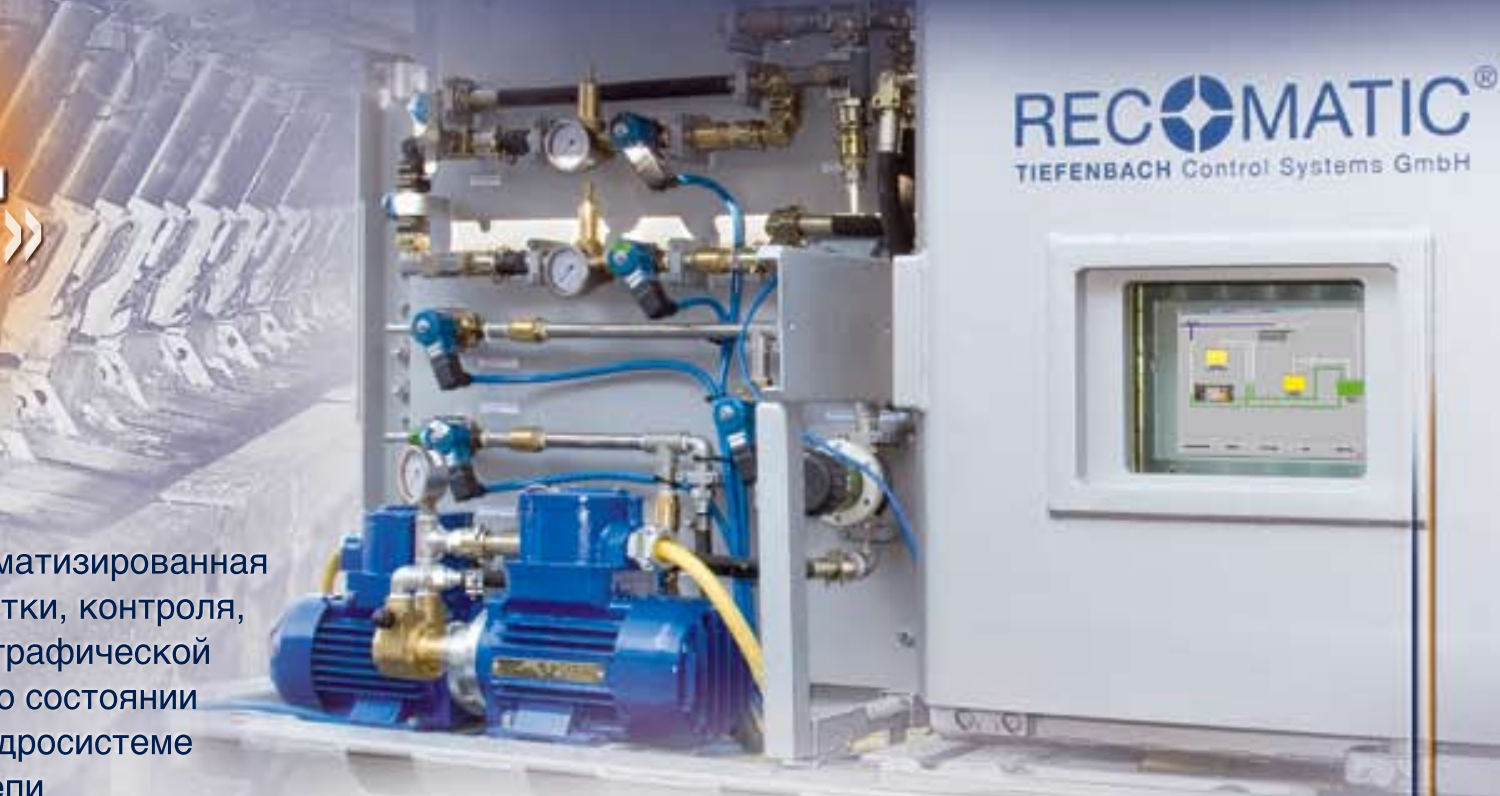

RECOMATIC ${ }^{\circ}$ - автоматизированная система сбора, обработки, контроля, анализа, архивации и графрической визуализации данных о состоянии рабочей эмульсии в гидросистеме механизированной крепи

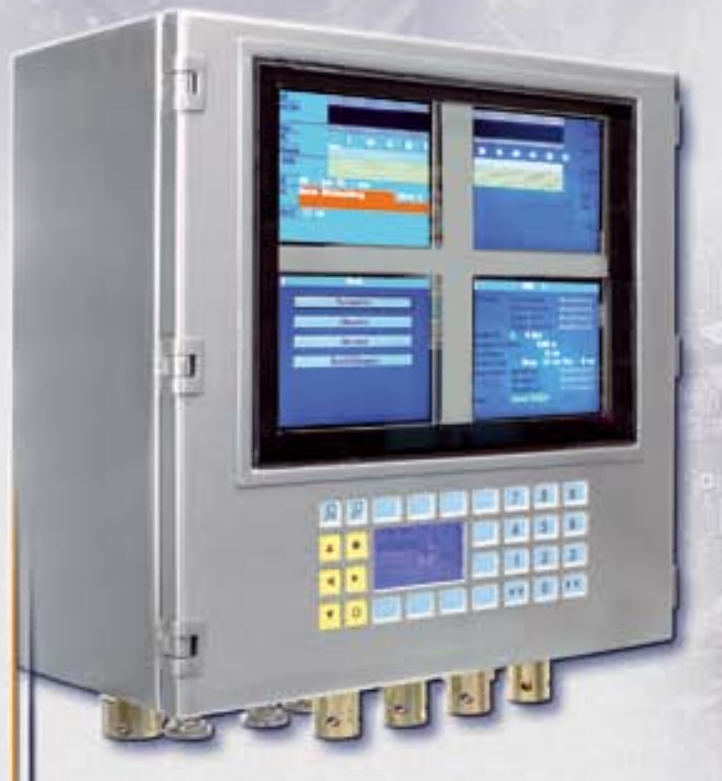

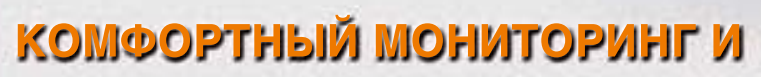
УГЈРАВЛЕНИЕ ГЈРОЦЈССАМИЈ

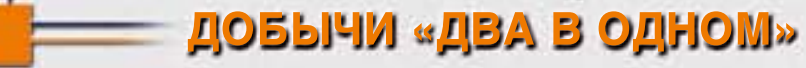

НOВВЙ ГОДУХOЛ В БОРВЕЕ С КОРРОЗИЕЙ - МЈИРНИМЈИЗАЦИУF ВАШИХ ЗАТРАТ
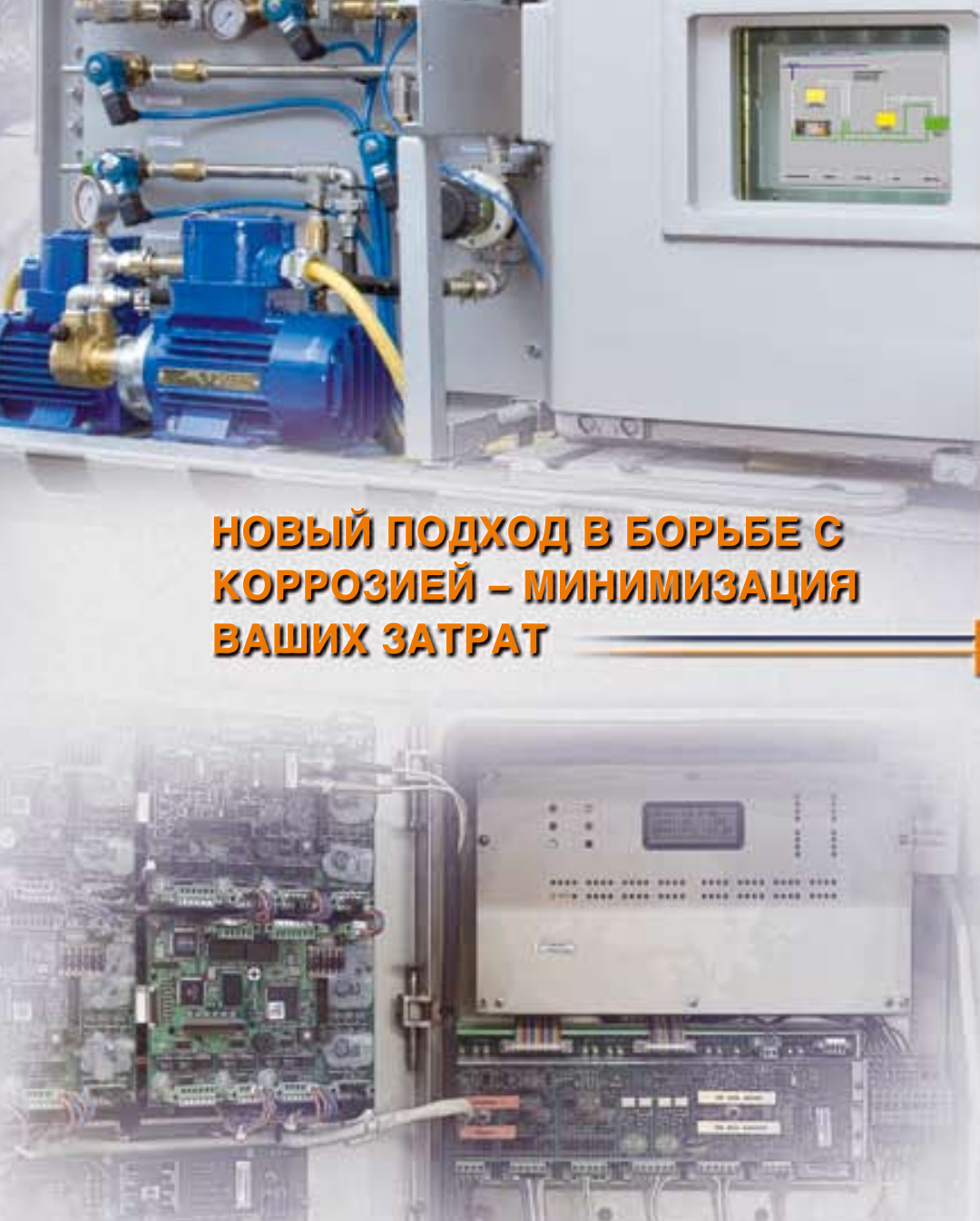

iLCC - искробезопасная центральная станция управления механизированной крепью с четырьмя графическими дисплеями и встроенной клавиатурой для просмотра параметров её работы и внесения изменений в настройки и конфигурацию

Mы даём импульсы $\gg>$

\section{WIR GEBEN IMPULSE $\gg>$ TIEFENBACH}

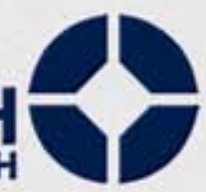

Rombacher Hütte 18a - 44795 Bochum Phone +49 (0) 234 - 777 66-0 Fax +49 (0) 234 - 777 66-999 info@tibacon.com

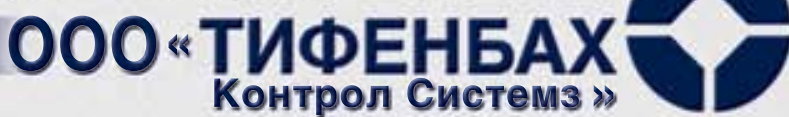

650021 Кемерово

ул. Новгородская 1

Тел./факс. +7 3842571245

tiefenbach-rus@mail.ru 


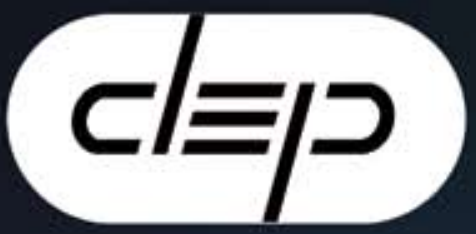

\section{КОМПАНИЯ}

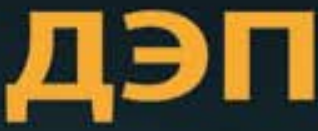

\section{Взрывозащищенный комплекс ДЕКОНТ-Ех нового поколения в горнодобывающей промышленности это:}

Разработка новых технических решений во взрывозащищенном исполнении.

Высокоскоростные оптоволоконные сети передачи данных и кроссовое оборудование.

Громкоговорящая цифровая связь и сигнализация-системы СТС-ДЭП.

Система шахтного видеонаблюдения.

Источники 6есперебойного искро6езопасного питания - ExUPS

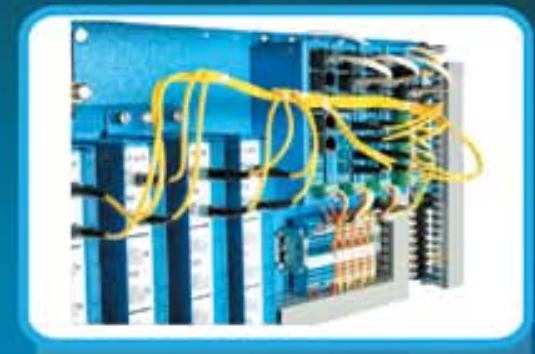

\section{Внедрение современных систем управления}

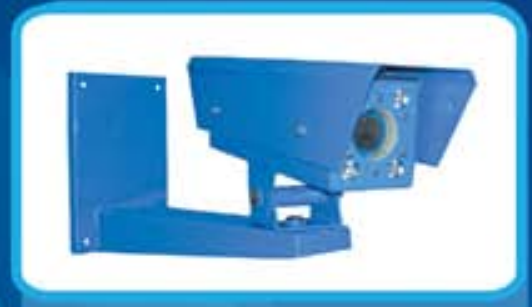

АСОДу «Энерго» - Система управления энергоснабжением. Предназначена для оперативного диспетчерского управления сетью электроснабжения шахт и рудников, построенной на базе комплектных распределительных устройств типа КРУВ-6, в том числе с микропроцессорными блоками управления. Взрывозащищенный счетчик электрической энергии собственного производства.

\section{Модификации морально устаревших систем автоматики}

«АСУК-ДЭП» - современная автоматизированная система управления конвейерным транспортом. Позволяет централизованно управлять сотнями конвейеров различной сложности, длины и модификации. Для адаптации системы управления к конкретному механизму конвейера используются различного рода настроечные параметры: конфигурации состава оборудования, временных интервалов, различного рода уставки
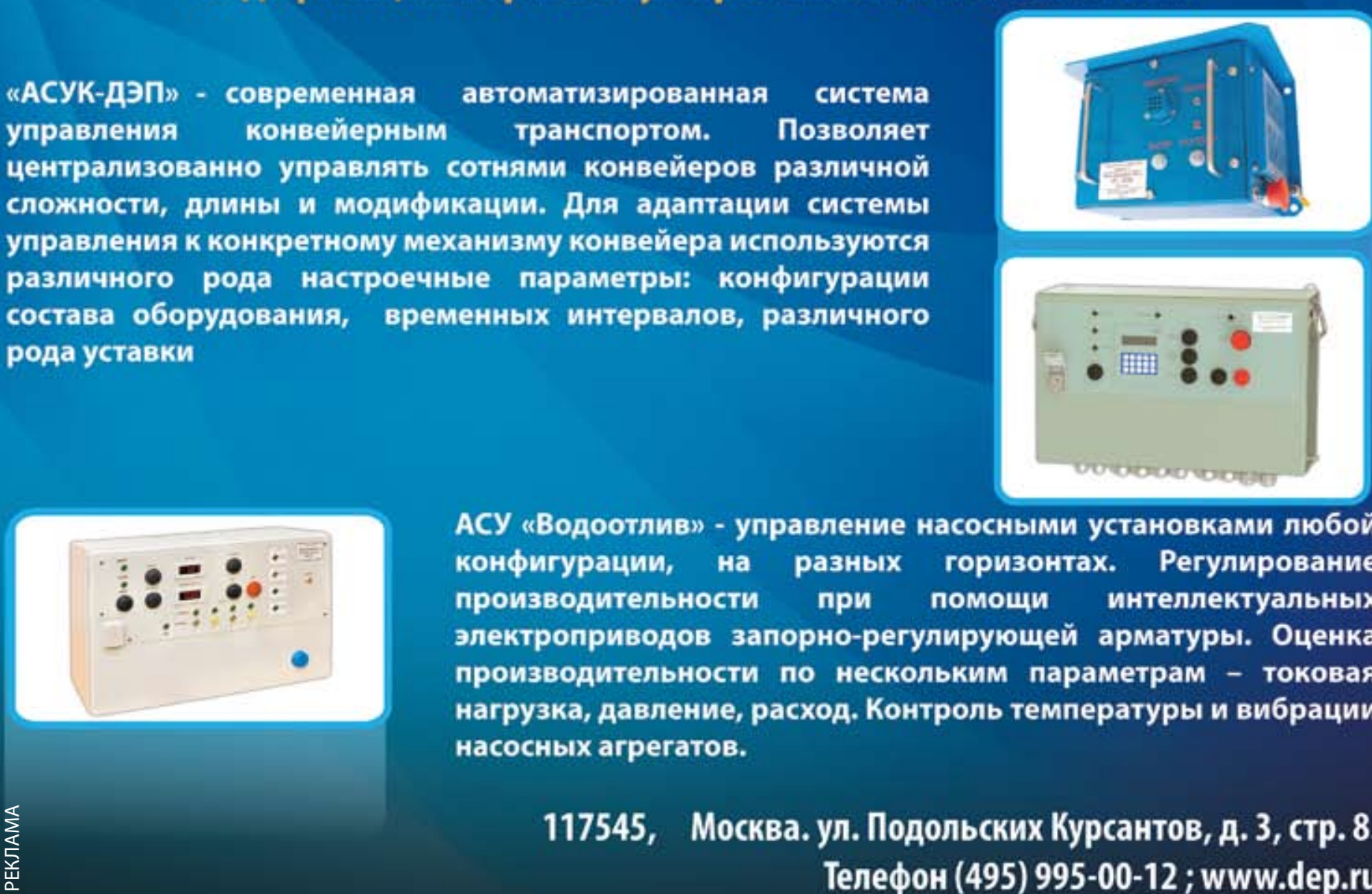

АСУ «Водоотлив» - управление насосными установками любой конфигурации, на разных горизонтах. Регулирование производительности при помощи интеллектуальных электроприводов запорно-регулирующей арматуры. Оценка производительности по нескольким параметрам - токовая нагрузка, давление, расход. Контроль температуры и вибрации насосных агрегатов.

117545, Москва. ул. Подольских Курсантов, д. 3, стр. 8. Телефон (495) 995-00-12 ; www.dep.ru 


\section{ООО НАУЧНО-ПРОИЗВОДСТВЕННОЕ ПРЕДПРИЯТИЕ "ЗАВОД МОДУЛЬНЫХ ДЕГАЗАЦИОННЫХ УСТАНОВОК"}

По инициативе ведущих угольных предприятий Кузбасса в 2009 г. было основано ООО «НПП «Завод МДУ» как завод-изготовитель модульных дегазационных (газоотсасывающих) установок, входящий в состав ООО «ТД КузбассЭлектромаш-Сервис».

Основное направление ООО «НПП «Завод МДУ» - предварительная дегазация разрабатываемых угольных пластов, дегазация смежных угольных пластов и откачивание концентрированных метановоздушных смесей из выработанных пространств. Установки типа МДУ с автоматизированной системой управления, отвечают всем требованиям «Инструкции по дегазации угольных шахт», «Инструкции по применению схем проветривания выемочных участков шахт с изолированным отводом метана из выработанного пространства с помощью газоотсасывающих установок».

На установках, производимых ООО «НПП «Завод МДУ» на базе ротационных и водокольцевых насосов производства итальянской фабрики ROBUSCHI, используются инновационные технологии с применением комплектующих самого высокого качества.

- Завод находится на территории Кемеровской области. Общая площадь предприятия насчитывает более 15000 кв. м, численность высококвалифицированных специалистов - более 180 человек.

- Завод производит модульные дегазационные (газоотсасывающие) установки двух типов:

о на базе ротационных насосов;

- на базе водокольцевых насосов.

- Производим монтаж и ввод оборудования в эксплуатацию.

- Проводим полный инструктаж и обучение персонала компаний-заказчиков (выезд специалистов на завод компании ROBUSCHI, г. Парма, Италия).

- Производим когенерационные установки (выработка электроэнергии и тепла из извлекаемого шахтного метана) совместно с компанией TEDOM a.S., (Чехия).

- Проводим полный инструктаж и обучение персонала компаний-заказчиков (выезд специалистов на завод компании TEDOM а.S., Чехия).

- Производим высокотемпературные факельные установки закрытого типа с возможностью последующего использования тепла.

- Изготавливаем тонкостенные дегазационные трубы диаметром от 300 до 1500 мм.

- Производим полный комплекс работ по бурению дегазационных скважин, включающий в себя:

о бурение дегазационных скважин;

о герметизацию дегазационных скважин;

o монтаж дегазационного трубопровода и подключение его к модульным дегазационным установкам.

- Структурной единицей ООО «ТД КузбассЭлектромаш-Сервис», производящей бурение скважин и монтаж дегазационного трубопровода, является ООО «ТМК».

- Обеспечиваем непрерывный мониторинг параметров газовой среды (концентрация метана, разрежение в трубопроводе, расход метановоздушной смеси, t, CO, O2) на всем пути ее прохождения от скважины (подземная дегазационная сеть) до вакуум-насосной станции.

- Предоставляем сервисное обслуживание, гарантийный и послегарантийный ремонт поставляемого оборудования.

- Изготавливаем металлоконструкции и контейнеры под технологическое оборудование.

- Производим строительные работы на поверхности под установку МДУ (Свидетельство СРО №0263.02-2011-4217079395-C-223).

654031, Кемеровская обл., г. Новокузнецк, Северное шоссе, 8 тел.: (3843) 991-991 e-mail: info@tdkes.ru www.zavodmdu.ru 
Главный редактор

АЛЕКСЕЕВ Константин Юрьевич

Директор Департамента угольной

и торфяной промышленности

Минэнерго России

Заместитель главного редактора ТАРАЗАНОВ Игорь Геннадьевич

Генеральный директор

ООО «Редакция журнала «Уголь»

Горный инженер, член-корр. РАЭ

Редакционная коллегия

АРТЕМЬЕВ Владимир Борисович

Заместитель генерального директора, директор по производственным операциям

ОАО «СУЭК», доктор техн. наук

БАСКАКОВ Владимир Петрович

Генеральный директор

ОАО «НЦ ВостНИИ», канд. техн. наук

ВЕСЕЛОВ Александр Петрович

Генеральный директор

ФГУП «Трест «Арктикуголь», канд. техн. наук

ГАЛКИН Владимир Алексеевич

Председатель правления ООО «НИИОГР»,

доктор техн. наук, профессор

ЕВТУШЕНКО Александр Евдокимович

Доктор техн. наук, профессор

ЗАЙДЕНВАРГ Валерий Евгеньевич

Председатель Совета директоров ИНКРУ,

доктор техн. наук, профессор

КОВАЛЕВ Владимир Анатольевич

Ректор КузГТУ, доктор техн. наук, профессор кОзОВОЙ Геннадий Иванович

Генеральный директор

ЗАО «Распадская угольная компания»,

доктор техн. наук, профессор

КОРЧАК Андрей Владимирович

Доктор техн. наук, профессор (МГГУ)

ЛИТВИНЕНКО Владимир Стефанович

Ректор НМСУ «Горный»,

доктор техн. наук, профессор

МАЛЫШЕВ Юрий Николаевич

Президент Академии горных наук,

директор Государственного геологического

музея им. В.И. Вернадского РАН,

доктор техн. наук, академик РАН

МОСКАЛЕНКО Игорь ВикторОвИч

Директор ОАО «УК «Кузбассразрезуголь»

МОХНАЧУК Иван Иванович

Председатель Росуглепрофа, канд. экон. наук

попов Владимир Николаевич

Доктор экон. наук, профессор

ПОТАПОВ Вадим Петрович

Зам. директора ИВТ СО РАН - директор

Кемеровского филиала, доктор техн. наук

nрофессор

ПучкОВ Лев Александрович

Доктор техн. наук, чЛ.-корр. РАН

РОЖКОВ Анатолий Алексеевич

Директор по науке и региональному

развитию ИНКРУ, доктор экон. наук, профессор

РЫБАК Лев Владимирович

Виче-президент ЗАО ХК «СДС»,

доктор экон. наук, профессор

суслов Виктор Иванович

Зам. Әиректора ИЭОПП СО РАН, чЛ.-Корр. РАН

ТАТАРКИН Александр Иванович

Директор Института экономики УрО РАН,

академик РАН

ХАФИЗОВ Игорь Валерьевич

Управляющий директор ОАО ХК «Якутуголь» ЩАДОВ Владимир Михайлович

Виче-президент ЗАО ХК «СДС»,

доктор техн. наук, профессор

() «УгоЛЬ», 2014
ЕЖКММЕСЯЧНЫЙ НАУЧНО-ТЕХНИЧЕСКИЙ И ПРОИЗВОДСТВЕННО-ЭКОНОМИЧЕСКИЙ ЖУРНАЛ

Основан в октябре 1925 года

УЧРЕДИТЕЛИ

МИНИСТЕРСТВО ЭНЕРГЕТИКИ

РОССИЙСКОЙ ФЕДЕРАЦИИ

РЕДАКЦИЯ ЖУРНАЛА «УГОЛЬ»

АПРЕЛЬ

$4-2014 / 1057 /$

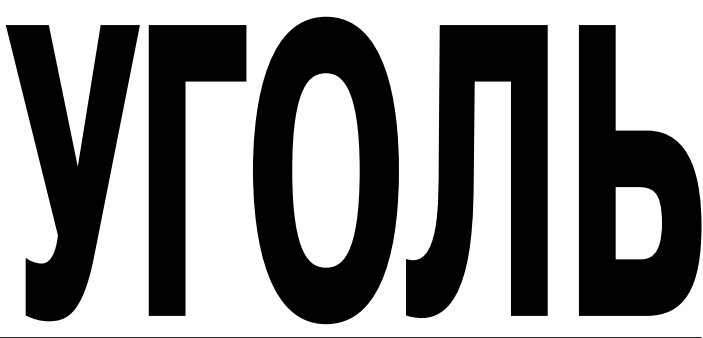

ВЫПУСК ПРИУРОЧЕН

к XXI Международной выставке

УГОЛЬ РОССИИ И МАЙНИНГ- 2014

(03 - 06.06.2014 г., Новокузнецк)

УГОЛЬ РОССИИ И МАЙНИНГ

UGOL ROSSII \& MINING

До встречи в Новокузнецке!

See you in Novokuznetsk! XXI International Specialized Exhibition «Ugol Rossii and Mining 2014»

Юров К. М.

Решение для соединения стационарного бронированного кабеля

с ПВХ-изоляцией в шахте

Solution for Connection of Stationary Armoured Cable with PVC Insulation in Mine

Пресс-служба ОАО ХК «СДС-Уголь»

Очистная бригада Игоря Иванова шахты «Листвяжная» первой в Кузбассе рапортовала

о добыче миллиона тонн угля с начала года

Igor Ivanov's Face Team in Mine "Listvyazhnaya» is the First in Kuzbass to Report On Million Ton

of Coal Produced Since the Start of the Year

Медведев А. Н., Морозов Е. А., Морозов Е. А.

Подъемно-поворотное приспособление для починки грузовых

и тракторных двигателей в полевых условиях

Lifting-Rotating Appliance for Afield Repair of Truck and Tractor Engines

Компания 000 «ФУКС ОЙЛ» рада сообщить о завершении строительства нового

высокотехнологичного завода по производству смазочных

и сопутствующих материалов FUCHS

LLC «FUCHS OIL» is Glad to Announce Completion of Construction of a New Hi-Tech Plant

for Production of FUCHS Lubricants and Collateral Materials

ПОДЗЕМНЫЕ РАБОТЫ

Леконцев Ю. М., Сажин П. В., Салихов А. Ф., Исамбетов В.Ф.

Расширение области применения метода направленного гидроразрыва (НГР)

Expanding Scope of Use of Directional Hydraulic Fracturing (DHF) Method

Перхова Наталья

Банк Rietumu: мы финансируем движение товара от закупки до реализации

Rietumu Bank: We Finance Goods Purchase to Sale Movement

ОРГАНИЗАЦИЯ ПРОИЗВОДСТВА

PRODUCTION SETUP

Буйницкий А. И., Килин Ю. А., Попов Д. В., Макаров А. М.

0 функционале исполнительного директора угольного разреза

On Composed Function of a Coal Strip Mine CEO

Попов Д. В., Тихонова Е. В., Алексенко В. С., Морозов А. В., Захаров С. И.

Совершенствование системы организационно-экономических отношений

в 000 «Восточно-Бейский разрез»

Improving System of Organizational and Economic Relations in LLC «Vostochno-Beysky Razrez»

PECYPCb

RESOURCES

Данилов А.П.

Некоторые аспекты взрыва относительно Теории поглощения энергии

On Some Aspects of Explosion with Regard to the Theory of Energy Absorption

Антонов Э. И., Грядущий К. В.

Двухступенчатая гидроэлеваторная установка для откачки и очистки глубоких зумпфов -

Two-stage Jet Gun Plant for Pumping and Cleaning of Deep Sump Holes 
ООО «РЕДАКЦИЯ ЖУРНАЛА «УГОЛЬ»

119049, г. Москва,

Ленинский проспект, д. 6, стр. 3, офис Г-136

Тел./факс: (499) 230-25-50

E-mail: ugol1925@mail.ru

E-mail:ugol@land.ru

\section{Генеральный директор}

Игорь ТАРАЗАНОВ

Ведущий редактор

Ольга ГлИНИНА

Научный редактор

Ирина КОЛОБОВА

Менеджер

Ирина ТАРАЗАНОВА

Ведущий специалист

Валентина ВОЛКОВА

ЖУРНАЛ ЗАРЕГИСТРИРОВАН

Федеральной службой по надзору

в сфере связи и массовых коммуникаций.

Свидетельство о регистрации

средства массовой информации

ПИ № ФС77-34734 от 25.12.2008 г

ЖУРНАЛ ВКЛЮЧЕН

в Перечень ведущих рецензируемых научных журналов и изданий, в которых должны быть опубликованы основные научные результаты диссертаций на соискание ученых степеней доктора и кандидата наук, утвержденный решением ВАК Минобразования и науки РФ

\section{ЖУРНАЛ ПРЕДСТАВЛЕН}

в Интернете на вэб-сайте

\section{www.ugolinfo.ru}

и на отраслевом портале "РОССИЙСКИЙ УГОЛЬ"

\section{www.rosugol.ru}

информационный партнер журнала - УгОЛЬНЫЙ ПОРТАЛ

\section{www.coal.dp.ua}

НАД НОМЕРОМ РАБОТАЛИ:

Ведущий редактор О.И. ГЛИНИНА

Научный редактор И.М. КОЛОБОВА

Корректор А.М. ЛЕЙБОВИЧ

Компьютерная верстка Н.И. БРАНДЕЛИС

Подписано в печать 02.04.2014.

Формат 60х90 1/8.

Бумага мелованная.

Печать офсетная.

Усл. печ. л. 10,0+ обложка.

Тираж 4500 экз.

Тираж эл. версии 1600 экз.

Общий тираж 6100 экз.

Отпечатано:

РПК ООО «Центр

Инновачионных Технологий»

117218, г. Москва, ул. Кржижановского, 31

Тел.: (495) 661-46-22; (499) 277-16-02

Заказ № 11318

๑ ЖУРНАЛ «УГОЛЬ», 2014

Соловьев В.Г., Марьин В. В.

Основные направления внедрения базальтовых композитных материалов

в горную промышленность

Basic Ways for Implementation of Basalt Composites in Mining Industry

Абдрахимов В.3., Абдрахимова Е.С.

Экологические и практические аспекты использования шлака от сжигания угля

в производстве керамических материалов на основе межсланцевой глины

Ecological and Practical Aspects of Coal Slag Use in Production of Intershale Clay-based Ceramics

ХРОНИКА

CHRONICLE

Хроника. События. Факты

The Chronicle. Events. The Facts

20-летие Академии горных наук

The $20^{\text {th }}$ Anniversary of the Academy of Mining Science

Неделя горняка - 2014

Miner's Week - 2014

ВОПРОСЫ КАДРОВ

Второй Всероссийский Чемпионат по решению кейсов в области горного дела

успешно стартовал в НMСУ «Горный»

The Second All-Russian Mining Cases Resolution Championship Started Successfully

in NMSU «Gorny»

\section{ПЕРЕРАБОТКА УГЛЯ}

Гришин И.А.

Модульный тип конструкции - современный подход к проектированию

обогатительных фабрик

Modular Design is Up-to-Date Approach in Designing of Beneficiation Plants

Кузнецов В. Г., Кузнецов И.П.

Технологические бункеры нового поколения для обогатительных фабрик

Technological Hoppers of New generation for Beneficiating Plants

\section{КАЧЕСТВО УГЛЯ}

Евстифеев Е. Н., Кужаров А. С., Попов Е. М.

Разработка нового связующего для производства бездымных брикетов

из антрацитовых штыбов

Development of a New Binding Agent for Production of Smoke-free Antracite Culm Briquettes

НЕДРА

Исабек Т. К., Алиев С. Б., Камаров Р. К., Имашев А. Ж., Бахтыбаева А. С.

Моделирование напряженно-деформированного состояния массива пород

вблизи очистных блоков с учетом временного фактора

Simulation of Stressed-Deformed State of Rock Massive Near the Stopes Given the Time Factor

эКология

Зеньков И. В. , Нефедов Б. Н. , Барадулин И. М. , Кирюшина Е. В. , Вокин В. Н.

Результаты дистанционного зондирования растительных экосистем и рельефа

горнопромышленных ландшафтов разреза «Назаровский»

Results of Geometrical Sounding of Vegetal Ecosystems and Mining Landscape Reliefs at Strip Mine «Nazarovsky»

\section{СТРАНИЦЫ ИСТОРИИ}

Иевлев А. А.

Печорскому угольному бассейну - 90 лет

To the Pechorsky Coal Basin - 90 year

\section{ЗА РУБЕЖОМ}

Зарубежная панорама World Mining Panorama

Подписные индексы:

— Каталог «Газеты. Журналы» Роспечати

$71000,71736,73422$
— Объединенный каталог «Пресса России»

$\mathbf{8 7 7 1 7 , ~ 8 7 7 7 6 , ~} \mathbf{3 8 7 7 1 7}$

— Каталог «Почта России» - 11538 
Ufi Всемирная ассоциация выставочной индустрии

6. Российский союз выставок и ярмарок

ॠ Торгово-промышленная палата РФ

21-я Международная специализированная выставка технологий горных разработок

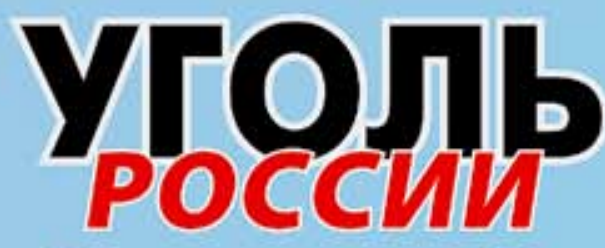

2

0

5-я специализированная выставка:

OXPAHA, БE3OПACHOGTBLPEAA 口ЖसИЗ

Июнь 3-6, 2014

НовоКУзнецК / РОсСИя

Главный

информационный спонсор:

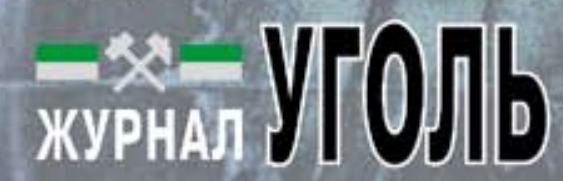

Выставка проводится под Патронажем Торгово-промышленной палаты РФ. при поддержнк:

г. Новокузнецк, Кемеровская обл.

т./Ф: (3843) 32-22-22, 32-11-13, e-mail: transport@kuzbass-fair.ru www.kuzbass-fair.ru

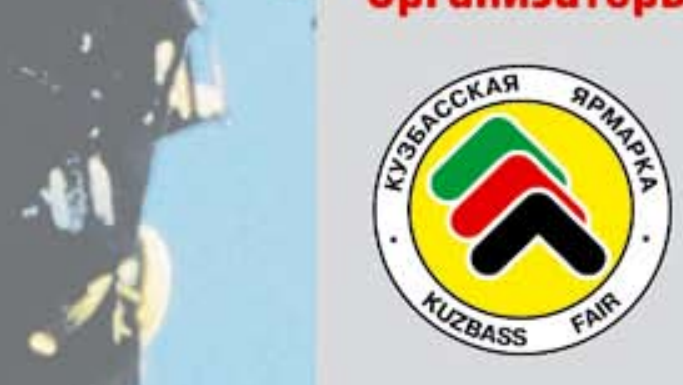

МЕСТО ПРОВЕДЕНИЯ: ул. Автотранспортная, 51, Заводской район, Г. Новокузнецк. 


\section{До встречи в Новокузнецке!}

С 3 по 6 июня 2014 г. в г. Новокузнецке пройдет XXI Международная специализированная выставка «Уголь России и Майнинг» и V Специализированная выставка «Охрана, безопасность труда и жизнедеятельности». Официальную поддержку мероприятию оказывают Минэнерго России, Союз немецких машиностроителей, отраслевое объединение «Горное машиностроение» (Германия), Ассоциация британских производителей горного и шахтного оборудования, Министерство промышленности и торговли Чешской Республики, администрации Кемеровской области и города Новокузнецка, Сибирский государственный индустриальный университет.

Кузбасс вновь встречает на своей земле сотни иностранных гостей и правительственных делегаций из Германии, Великобритании, Польши, Китая и еще более чем двух десятков стран. На площади более 40 тыс. кв. м будут представлены новейшие технологии и оборудование для угольных и горнодобывающих предприятий, а также широкий спектр товаров и услуг в области производственной безопасности. Форум такого масштаба имеет принципиальное значение для развития экономики региона и топливно-энергетического комплекса России в целом, способствуя привлечению в отрасль новейших технологий и инвестиций.

Как всегда в рамках выставок пройдут научно-практические конференции, совещания, семинары, круглые столы, презентации новых разработок. В центре деловой программы - вопросы реструктуризации шахт, повышения эффективности угольного производства и безопасности труда шахтеров. В этом году мероприятия научно-деловой программы по традиции пройдут в формате тематических дней: «День генерального директора», «День технического директора», «День главного механика», где специалисты традиционно повышают свой профессиональный уровень, обсуждают наиболее актуальные вопросы в рамках деловых мероприятий.

Организаторы форума - выставочная компания «Кузбасская ярмарка», г. Новокузнецк (член Всемирной ассоциации выставочной индустрии, Российского Союза выставок и ярмарок, Кузбасской Торгово-промышленной палаты) и «Мессе Дюссельдорф ГмбХ» (Германия), организующая выставки на территории России с начала 1960-х гг.
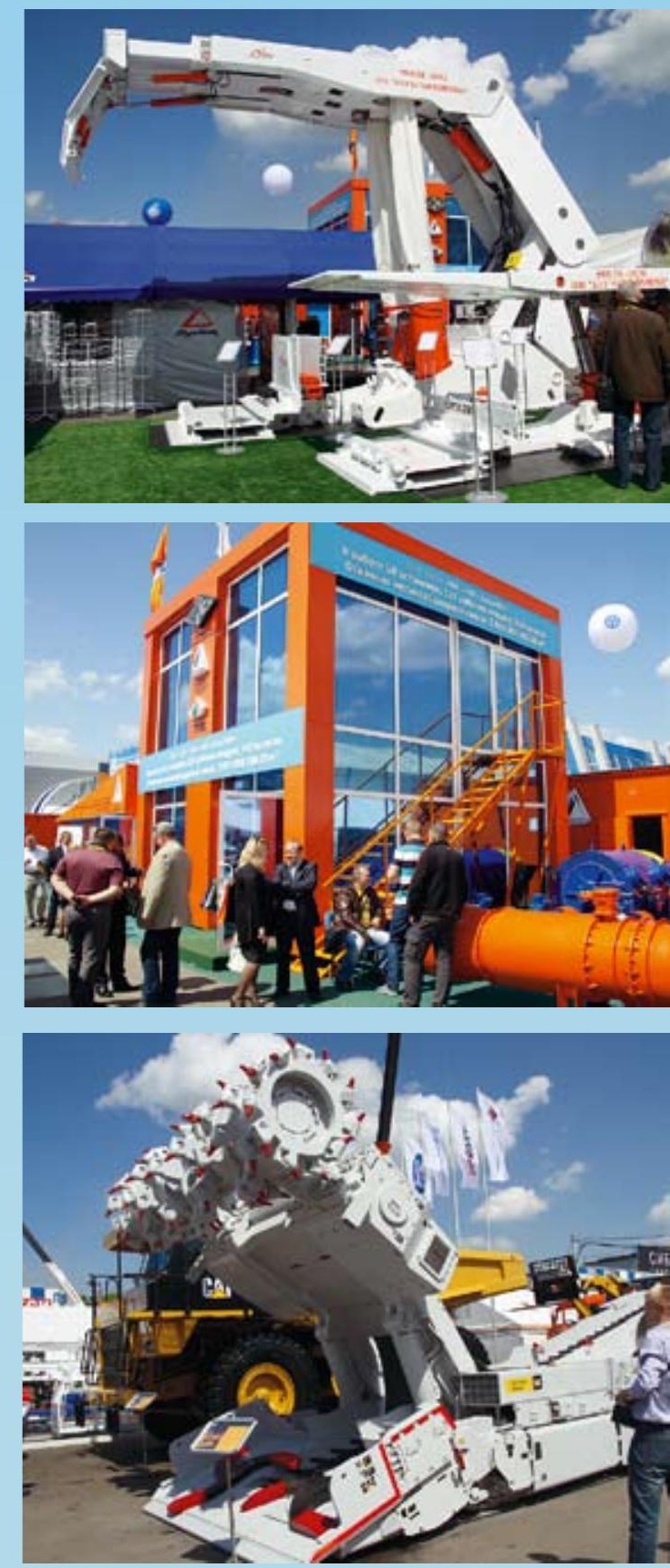

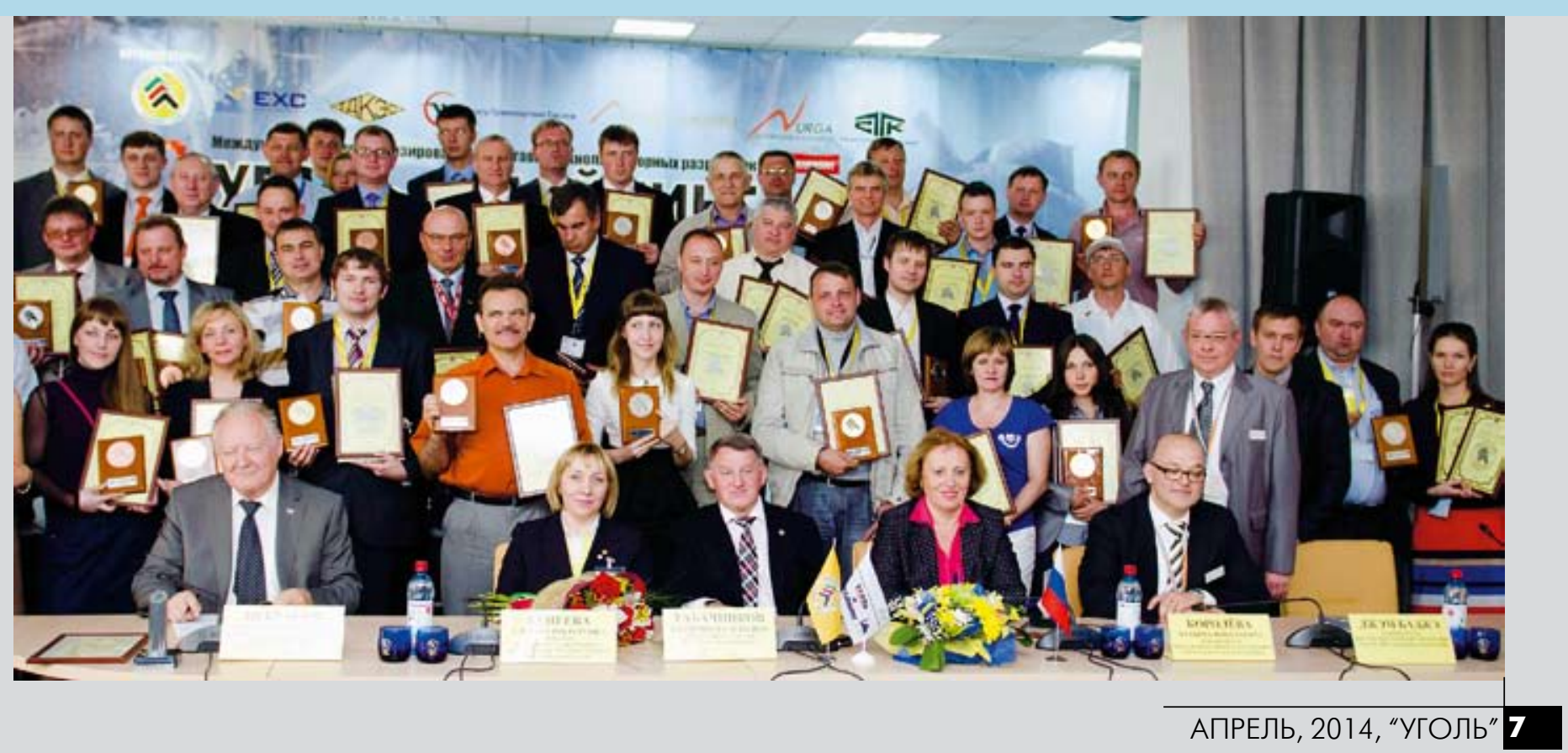




\section{Решение для соединения стационарного бронированного кабеля с ПВХ-изоляцией в шахте}

\section{ЮРОВ Константин Михайлович \\ Старший инженер $3 A O$ «ЗМ Россия»}

В настоящей статье рассмотрен вопрос соединения бронированного кабеля напряжением 3,6/6 (7,2) кВ с ПВХизоляцией, применяемого в угольных шахтах.

Ключевые слова: кабельная муфта, кабель, ПВХ-изолячия, КШВЭБбШв, муфта ЗМ 92-А 615.

Бронированный кабель с ПВХ-изоляцией среднего напряжения 3,6/6 $(7,2)$ кВ в последние годы является основным кабелем для прокладки в стационарных сетях угольных шахт. От предыдущего кабеля с бумажной пропитанной изоляцией его отличает большая простота монтажа, удобство прокладки, а также высокие характеристики по нераспространению горения его оболочкой. Сегодня самым популярным типом бронированного кабеля для применения в угольных шахтах является кабель типа КШВЭБбШв (рuс. 1).

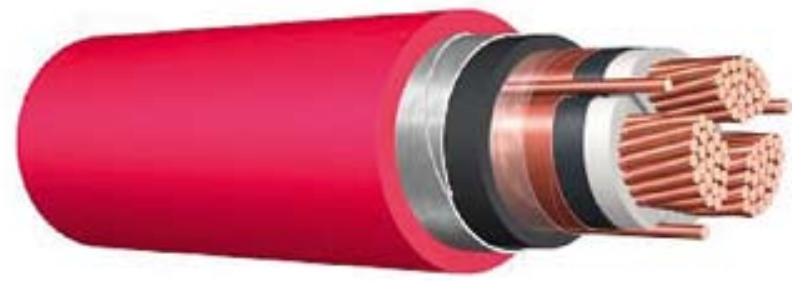

Рис. 1. Кабель с ПВХ-изолячией типа КШВЭБбШв

От предыдущего поколения кабеля с БПИ-изоляцией его отличает не только тип применяемой изоляции (сухая сплошная изоляция вместо бумажной пропитанной), но и система экранирования. Для кабеля типа КШВЭБбШв предусмотрен индивидуальный экран по жилам, выполненный из медных лент. Это обстоятельство делает кабель более безопасным в эксплуатации и в то же время накладывает дополнительные требования к его монтажу и ремонту. Так, при соединении кабеля индивидуальный экран по жилам должен быть восстановлен. В противном случае возникает как опасность выноса электрического потенциала на поверхность кабеля, так и опасность неотключения токов утечки изоляции.

Дополнительным ограничением являются размеры и принципы монтажа самих соединительных муфт.

И по сей день на некоторых шахтах встречаются заливные битумные муфты. Технология, при которой разогретый на поверхности до текучего состояния битум спускается под землю и заливается в многокилограммовые чугунные формы, является сколь неудобной, столь же и опасной.

И даже муфты 3М предыдущей серии 92-ОТ 421-3, предназначенные для монтажа на кабеле с БПИ-изоляцией, имеют существенное ограничение: для их монтажа требуется специальный шприц-пистолет, с помощью которого масса компаунда заливается внутрь сростка.

В связи с этим энергетики шахт Кузбасса и Воркуты поставили перед нами задачу разработать комплект муфты для кабеля типа КШВЭБбШв, которая должна иметь малые массу и габариты и монтироваться без применения специального шприца-пистолета. При этом конструкция муфты должна предусматривать восстановление всех основных элементов кабеля, включая экран по жилам и целостность брони. По-возможности, муфта должна стоить на рынке дешевле своих основных современных аналогов.

И такая задача была успешно решена!

Уважаемые коллеги, представляем Вашему вниманию комплект соединительной муфты ЗМ серии 92-А 615 для монтажа на кабеле с ПВХ-изоляцией типа КШВЭБбШв (puc. 2).

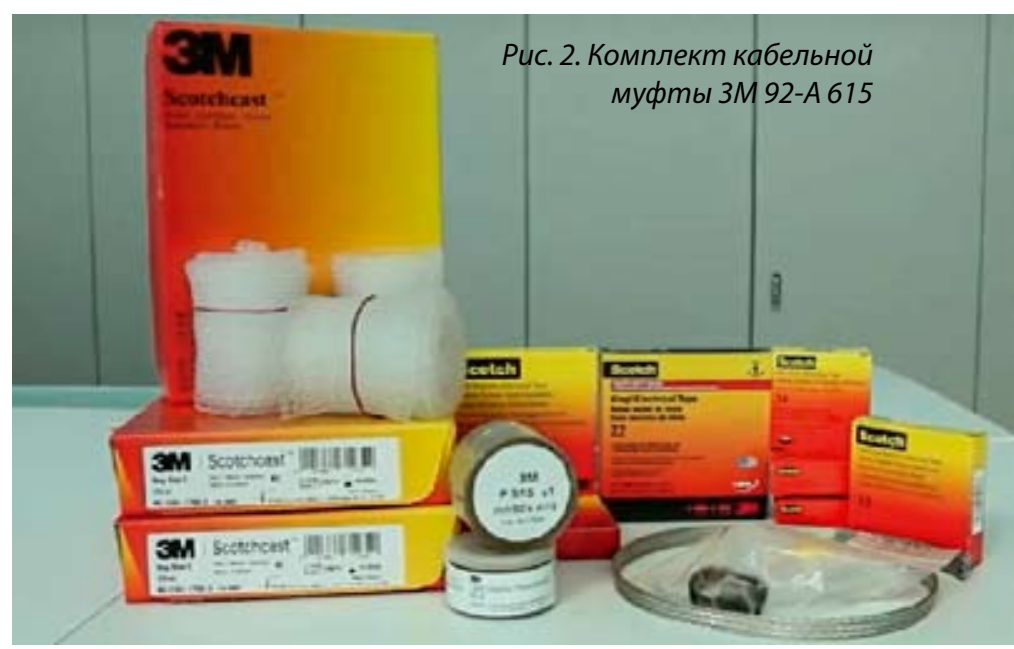

Комплект 92-А 615 включает в себя все необходимые изоляционные и экранирующие материалы для монтажа, весит около трех килограммов.

Данная муфта проста в монтаже, и справиться с ним может даже не имеющий большого опыта работник. Особое внимание следует уделить тому обстоятельству, что благодаря встроенному в пакет с компаундом заливному клапану теперь достаточно лишь состыковать его с отверстием приемного клапана муфты и осуществить заливку вручную, без использования специального инструмента (puc. 3). 


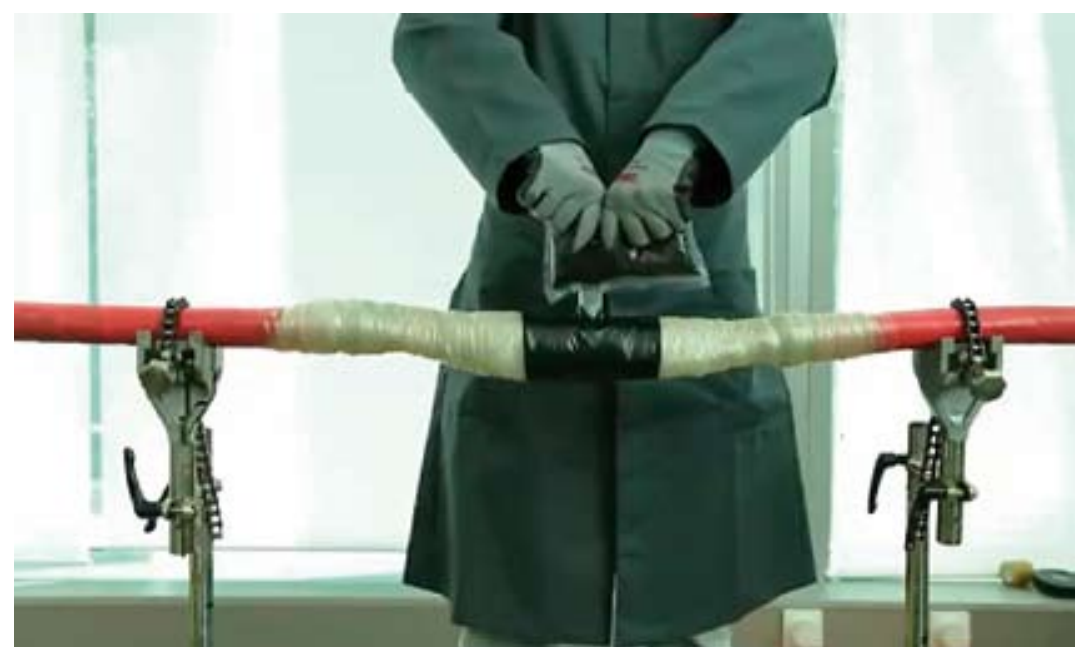

Puс. 3. Монтаж муфты 3М 92-A 615

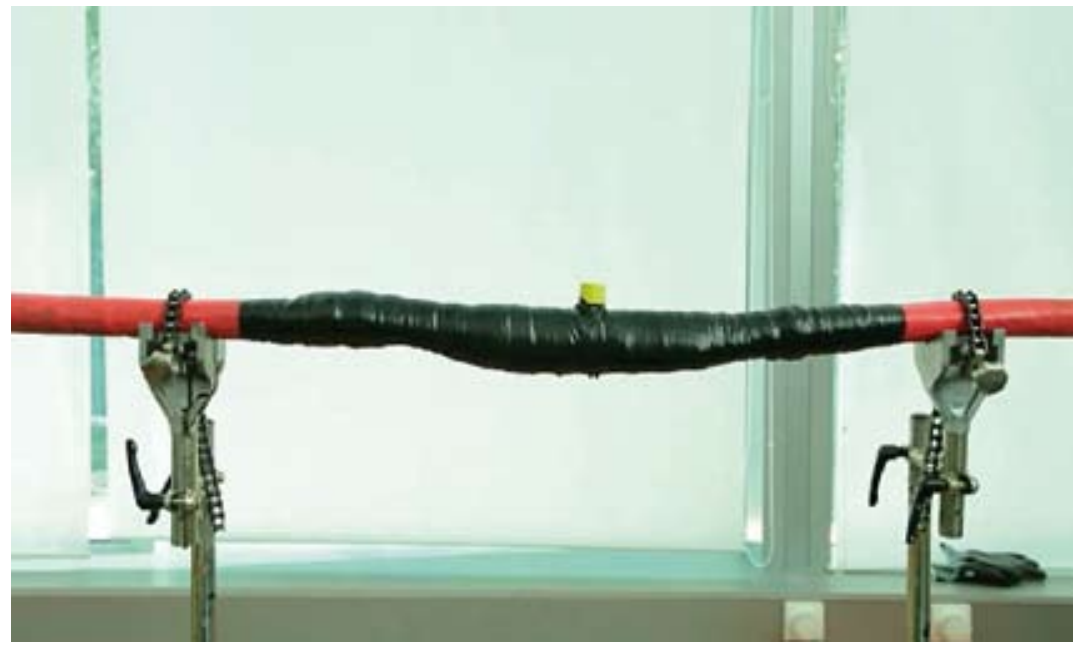

Puс. 4. Муфта 3М 92-А 615 в смонтированном состоянии
В смонтированном виде (рис. 4) муфта обладает схожими с целым участком кабеля габаритами, но при этом обеспечивает изоляционные, экранирующие и бронирующие свойства кабеля. Муфта обладает отличной стойкостью, как к удару, так и к тяжению.

Помимо прочих достоинств, на сегодняшний день муфта 92-А 615 дешевле своих современных аналогов.

За долгие годы эксплуатации кабельные муфты 3М показали свою высокую работоспособность и стали отличным подспорьем для шахтеров, позволив облегчить и обезопасить труд человека, снизить простои техники и увеличить добычу угля. Новая муфта серии 92-А 615 призвана продолжить славные традиции решений Компании 3М для предприятий горной добычи!

Если по какой-то причине вы или ваше предприятие пока еще не используете этой муфты при монтаже кабельных линий, но желаете попробовать ее в работе, свяжитесь с нашими представителями или партнерами в вашем или соседнем регионе и получите от них высококачественную поддержку в вопросах применения электроизоляционных материалов 3М.

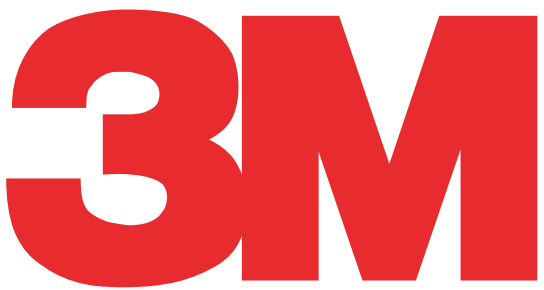

\section{3М Россия}

121614, Москва,

ул. Крылатская, д. 17, стр. 3,

Бизнес-парк «Крылатские холмы» Тел.: +7 (495) 7847474 www. 3mrussia.ru/Mining www. 3MElectro.ru

\author{
Клиентский центр \\ в Санкт-Петербурге \\ 192029, Санкт-Петербург, \\ пр. Обуховской обороны, \\ д. 70, корп. 3/А, 5-й эт. \\ Бизнес-Центр «Фидель» \\ Тел.: +7 (812) 3366222
}

\section{Клиентский центр в Екатеринбурге \\ 620014, г. Екатеринбург, ул. Бориса Ельцина, д. 1А, БЦ «Президент», 11-й этаж Тел.: +7 (343) 228-22-88; +7 (343) 228-22-99}

Региональные представители - специалисты по предприятиям горнодобывающей индустрии и металлургии:

\section{Евгений Дремин}

г. Кемерово Регион: Кузбасс, Кемеровская обл. Моб. тел.: +7 (913) 407-46-35

\section{Константин Юрасов}

г. Екатеринбург

Регион:Урал

Моб. тел.: +7 (912) 675-42-78

\section{Роман Саляхов}

г. Новокузнецк

Регион: Кемеровская обл., Томская обл. Моб. тел.: +7 (913) 333-99-99

Алексей Красноперов

г. Екатеринбург Регион: Северный Урал Моб. тел.: +7 (912) 610-20-15

\section{Михаил Попков}

Санкт-Петербург

Регион: Архангельская обл.,

Республика Коми, Санкт-Петербург

Моб. тел.: +7 (921) 849-97-11

\section{Андрей Зоммер}

г. Красноярск

Регион: Сибирь и Дальний Восток Моб. тел.: +7 (983) 077-53-61

Сергей Пшеничный

г. Челябинск

Регион: Башкирия, Южный Урал Моб. тел.: +7 (912) 893-23-71 

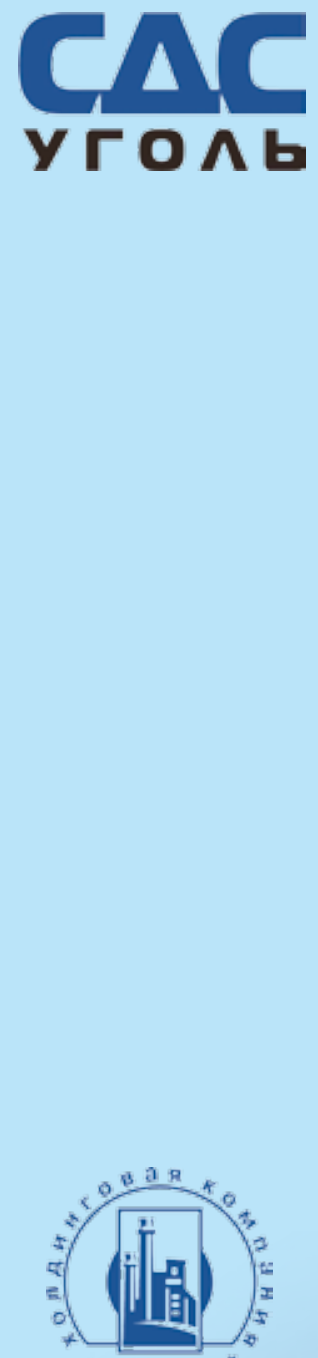

СИБИРСКИЙ ДЕЛОВОЙ СОЮ3

\section{Пресс-служба ОАО ХК «СДС-Уголь» информирует}

\section{Очистная бригада Игоря Иванова}

шахты «Листвяжная» первой в Кузбассе рапортовала

\section{о добыче миллиона тонн угля с начала года}

17 марта 2014 г. горняки ООО «Шахта Листвяжная» выдали на-гора миллион тонн угля с начала года. Это лучший результат среди предприятий ОАО ХК «СДС-Уголь» и первый в Кузбассе!

Производственное достижение трудовой коллектив очистного участка №1 установил в лаве №1109 (пласт «Сычевский IV»). Добыча в лаве №1109 ведется с использованием механизированного комплекса DBT (Bucyrus, Германия) с комбайном SL-500 (Eickhoff, Германия). Отработку ведет бригада Игоря Иванова (начальник участка №1 Мельников Сергей Николаевич).

До конца года холдинг «Сибирский Деловой Союз» в рамках реализуемой инвестиционной программы развития направит на ООО «Шахта Листвяжная» около 300 млн руб.

Для повышения уровня промышленной безопасности при отработке угольных пластов на предприятии ведется строительство нового, более мощного, вентилятора главного проветривания, запуск которого планируется в четвертом квартале т. г. Холдинговая компания «Сибирский Деловой Союз» инвестировала в строительство нового объекта 63 млн руб.

По итогам 2013 г. объем добычи на шахте «Листвяжная» составил 4,3 млн т угля. В 2014 г. горняки предприятия планируют выдать на-гора 5,9 млн т угля.

Наша справка

ОАО ХК «СДС-Уголь» входит в тройкулидеров отрасли в России. По итогам 2013 г. предприятия ОАО ХК «СДС-Уголь» добыли 24,5 млн т угля. 86,2\% добываемого угля поставляется на экспорт. ОАО ХК «СДС-Уголь» является отраслевым холдингом ЗАО ХК «Сибирский Деловой Союз». В зону ответственности компании входят 25 предприятий, расположенных на территории Кемеровской области.

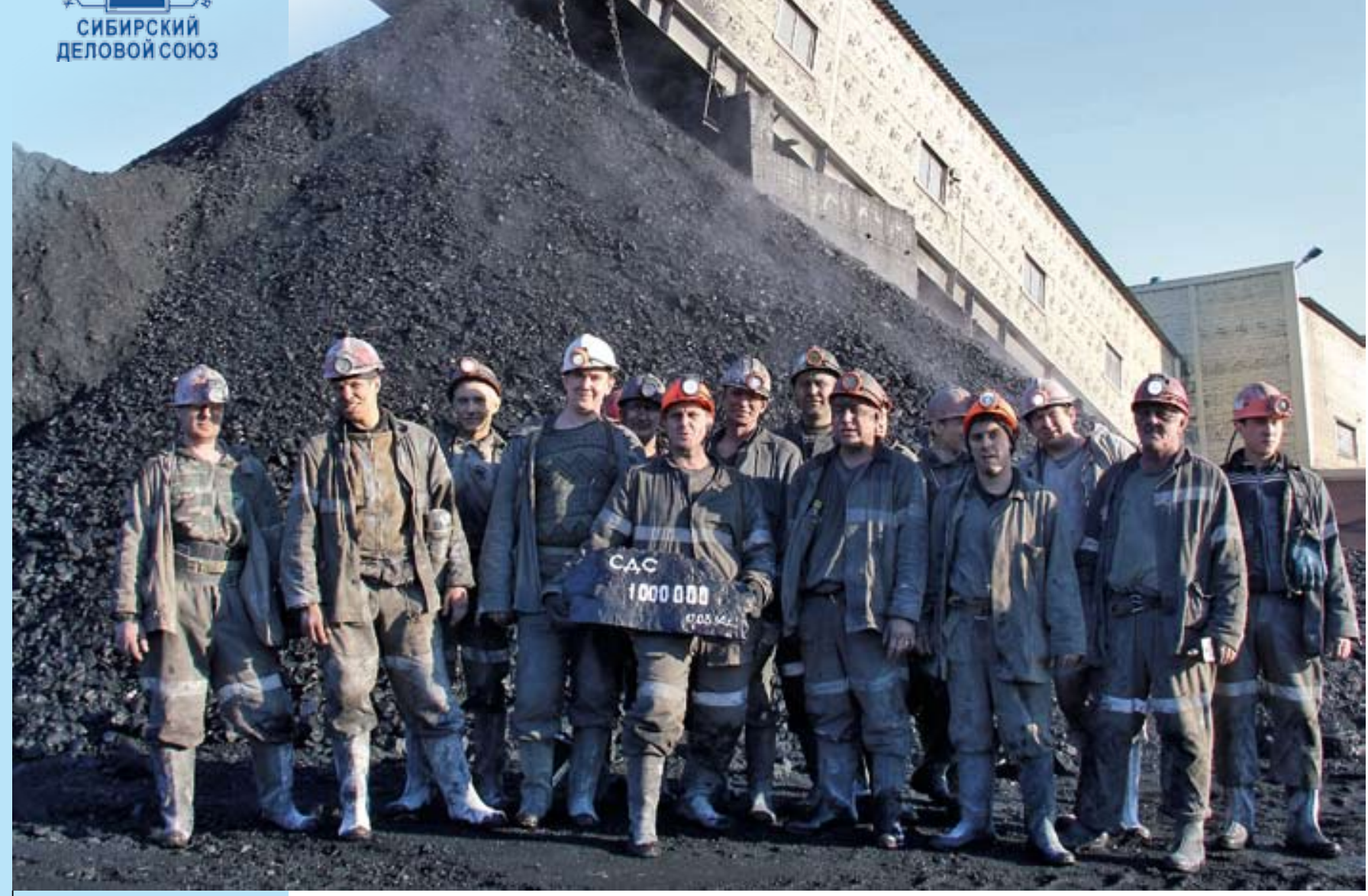




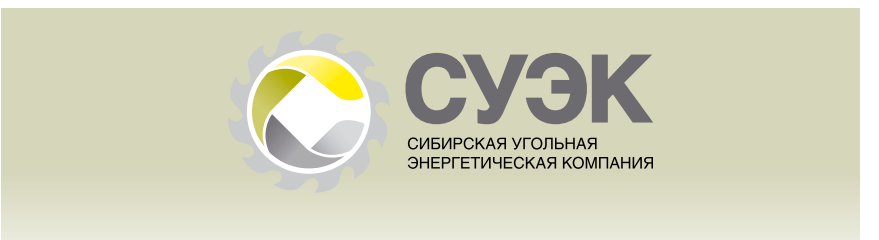

\section{В Красноярском крае стартовала акция «Десятилетию} трудовых отрядов СУЭК -

\section{десять добрых дел»}

В этом году исполняется 10 лет одному из самыхуспешных социальных проектов Сибирской угольной энергетической компании - «Трудовым отрядам СУЭК».

В Красноярском крае юбилейный сезон стартовал на несколько месяцев раньше обычного - в честь такого события школьники решили подарить каждой шахтерской территории региона - городам Бородино, Назарово и Шарыпово, а также Рыбинскому, Назаровскому и Шарыповскому районам - десять добрых дел в рамках одноименной акции.

Реализация проекта началась уже в феврале. Школьники приняли участие в молодежном форуме г. Бородино, провели посвященные 25-летию вывода войск из Афганистана соревнования по волейболу с участниками боевых действий в мирное время, организовали праздничные акции ко Дню защитника Отечества. В планах у ребят из трудовых отрядов СУЭК еще много мероприятий: благоустройство территорий, содействие муниципальным учреждениям - больницам, школам и детским садам, помощь инвалидам и сиротам, пенсионерам и ветеранам, различные благотворительные и социальные акции, спортивные состязания.

Итоги проекта «Десятилетию отрядов СУЭК - десять добрых дел» будут подведены в конце мая. Лучших участников акций отметят на открытии десятого трудового сезона отрядов СУЭК.

Год за годом трудовые отряды СУЭК повышают престиж и набирают популярность у молодежи угледобывающих территорий России. Они становятся для большинства ребят первой ступенькой к постижению своих профессиональных способностей, школой трудового воспитания, гражданского и общественного становления.

«Для некоторых ребят трудовые отряды СУЭК стали первым опытом знакомства с историей, славными традициями горняков и первым шагом к профессии шахтера, - считает координатор работы отрядовцев в западных территориях Красноярского края Ирина Леднева. - Угольщики СУЭК делают большое делопомогают ребятам обрести себя, найти свой путь в жизни, выбрать свою будущую профессию. Уверена, все они вырастут настоящими людьми, тружениками и патриотами нашей Родины!».

\section{Вы не знаете что делать с коксовой пылью?}

\author{
Решение: \\ Гранулирование.
}

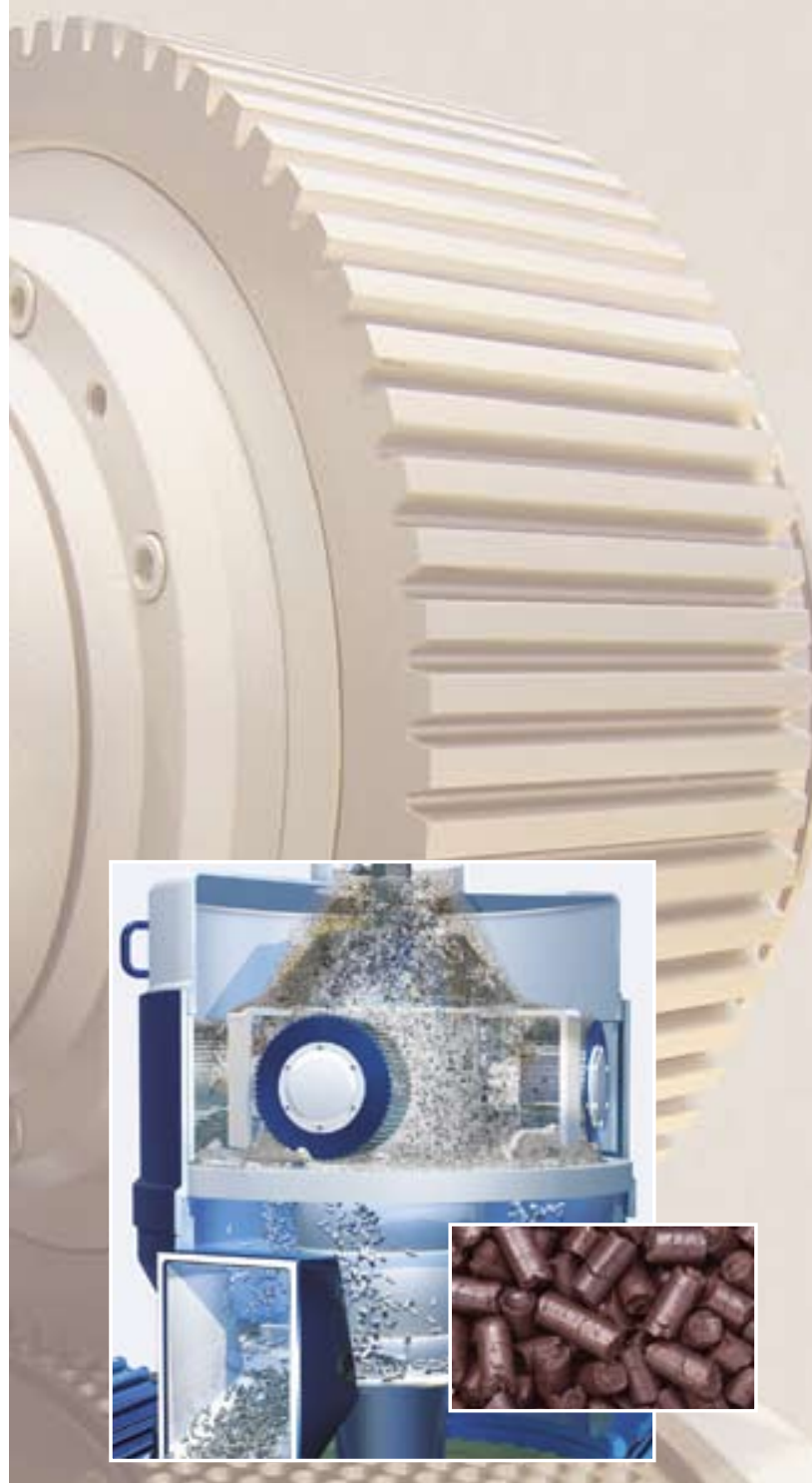

Благодаря пеллетированию кокосовой пыли «отходы» превращаются в полноценный кокс для дальнейшего использования в доменных печах.

\section{IOIKAHL}

Представительство

"Амандус Каль ГмбХ и Ко.КГ"

121357 г. Москва, ул.Верейская, 17,

Бизнес-Центр "Верейская Плаза-2", офис 318, тел. + 74956443248

info@kahl.ru www.akahl.ru 


\section{Подъемно-поворотное приспособление для починки грузовых и тракторных двигателей в полевых условиях}

\author{
МЕДВЕДЕВ Алексей Николаевич \\ Заместитель начальника отдела \\ инженерных изысканий \\ Филиал ОАО «Воентелеком» - 17 ЦПИС \\ МОРОЗОВ Евгений Александрович \\ Буровой мастер ООО «Бериллит» \\ МОРОзОВ Егор Александрович \\ Инженер 000 «Простор»
}

При проведении буровых работ в тяжелых геологических условиях полезно иметь передвижную мастерскую для починки грузовых и тракторных двигателей весом до двух тонн. Известные приспособления для починки слишком громоздки для такой мастерской. Поэтому предпринята попытка создания набора общепринятых приспособлений в условиях полевой передвижной мастерской, в частности подъемно-поворотного приспособления для починки тяжелого двигателя. Пользуемся им три года, и, видимо, на всем белом свете такого больше нет.

Ключевые слова: кантователь, стенд, стапель для ремонта двигателей.

Контактная информация: www. voentelecom. ru; www. дело9м. pq; www. npo-prostor. ru

Восемнадцать лет занимаемся бурением скважин на воду на севере Подмосковья, в грунтах, насыщенных камнями, оставленных Московским оледенением 125 тысяч лет тому назад. Особенности работы: мы либо бурим, либо ре-

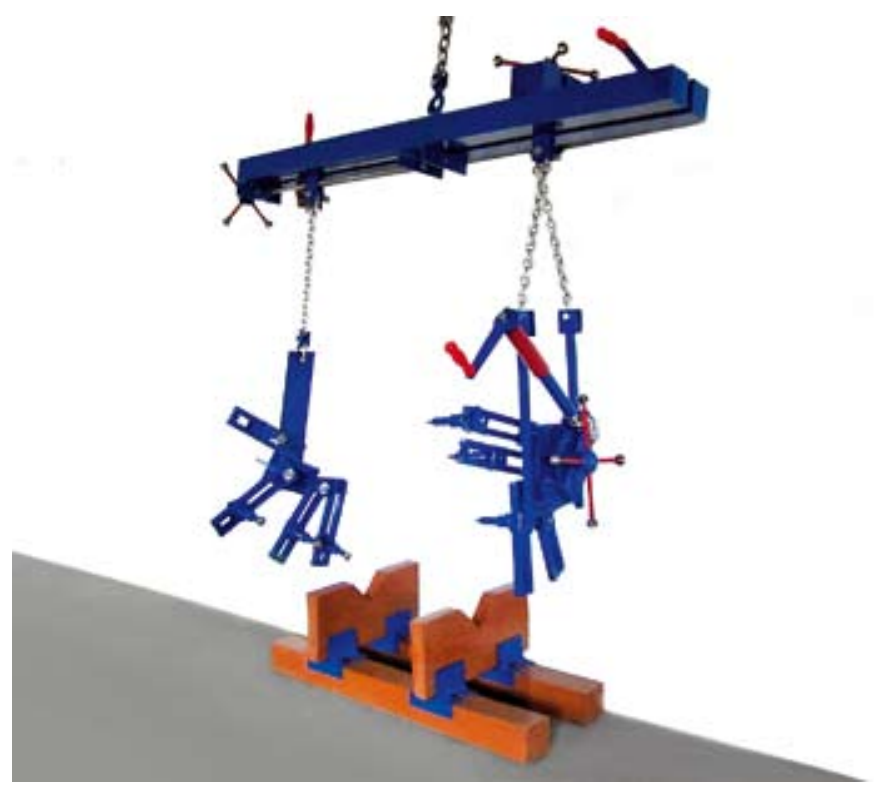

Рис. 1. Общий вид приспособления

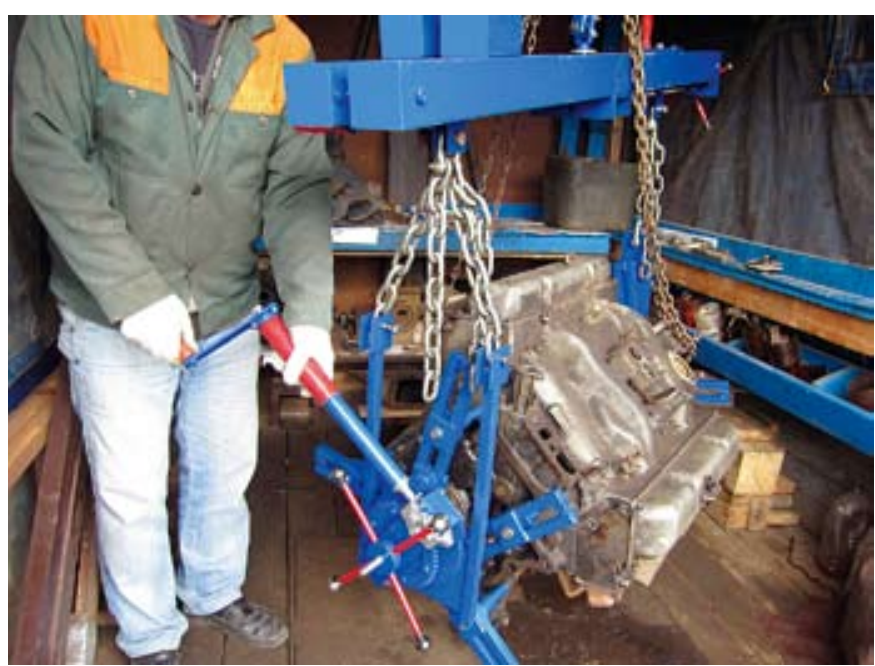

Рис. 2. Пример использования приспособления

монтируемся. Поэтому придумали, сделали и применяем необычное подъемно-поворотное приспособление для починки грузовых и тракторных двигателей (рис. 1, 2).

Особенности приспособления:

- пригодно для поворота любого двигателя с парой параллельных фланцев блока цилиндров,

- пригодно для двигателей весом до двух тонн,

- весит менее ста килограммов. Длина - 1600 мм. Перевозится в легковом авто.

Двигатель чинится на деревянной подставке.

Двигатель поворачивают над подставкой:

- редуктором,

- или редуктором и ручным тормозом,

- или монтажкой и ручным тормозом,

— или ручным тормозом и подбором положения оси вращения двигателя относительно центра тяжести двигателя.

\section{РАБОТА С ПРИСПОСОБЛЕНИЕМ}

Работа с приспособлением осуществляется следующим образом:

- в резьбовые отверстия фланцев ввинчиваются шпильки. В гладкие отверстия вставляются болты;

- на шпильки (болты) последовательно надеваются детали приспособления;

- редуктор нанизывается на ось и крепится одной гайкой. Цепляются цепи;

- сообразно размерамдвигателя потраверсеперемещают подвесы: левый - с шагом 100 мм, правый — плавно. Гайкой настраивают длину правого подвеса в пределах 150 мм;

- двигатель приподнимают над подставкой. Возможно, силовым винтом подвес траверсы перемещают для выравнивания положения двигателя;

- двигатель поворачивают. Возможно, силовым винтом подвес траверсы перемещают, и двигатель опускают на подставку. 


\section{ОСОБЕННОСТИ ИСПОЛЬЗОВАНИЯ}

- Приспособление можно целиком собрать и хранить на цепях траверсы и в таком виде крепить кдвигателю, что удобно при починке одинаковых двигателей.

- По своему желанию моторист может поворачивать двигатель не только редуктором, но монтажкой или ручным тормозом управлять самопроизвольным вращением двигателя.

- Можно отказаться от использования и редуктора, и монтажки, если моторист, сняв или установив тяжелый узел (коленчатый вал, головку блока цилиндров), сумеет определить новое положение центра тяжести двигателя и, ослабив четыре гайки приспособления, изменит положение оси вращения двигателя. Затем приподнятый над подставкой двигатель будет поворачиваться самопроизвольно, управляясь ручным тормозом.

- Подставка подбита резиной так, что ее сила трения о пол больше силы трения о пол башмаков моториста. Возможно, при больших усилиях закручивания или откручивания крепежа, в нижнюю часть двигателя нужно вкрутить четыре шпильки, которые упрутся в подставку и не позволят двигателю шевелиться.

- Отдельно взятая траверса с перемещаемым подвесом может быть полезна при установке двигателя в моторный отсек, например вместе с коробкой переключения передач: перемещая место подвески траверсы, подвешенный на ней двигатель можно наклонять.

Приспособление применяется в передвижной мастерской для починки грузовых и тракторных двигателей в полевых условиях. Опыт бурения показывает: стоимость доставки неисправного автобурового станка или его неисправного двигателя в обычную мастерскую может превышать стоимость починки, а качество работ в многолюдной мастерской с исторически сложившимся низким уровнем производственных отношений несравнимо с качеством работы мастера и его ученика.

\section{ПРЕИМУЩЕСТВА ПРИСПОСОБЛЕНИЯ}

Приспособление имеет следующие преимущества:

- приспособление висит, а не стоит, и его растягиваемые части меньше и легче, чем сжимаемые в кантователях ${ }^{1}$, ${ }^{2}$, и его легче и быстрее перемещать по мастерской;

- прижатое к стене мастерской оно не занимает места;

- себестоимость такого приспособления, рассчитанная по единым нормам и расценкам СССР (с учетом поправочных коэффициентов), существенно ниже себестоимости кантователей двигателей весом до двух тонн, предлагаемых в Сети.

Подробности можно посмотреть на сайте ООО «Бериллит» www. дело9м. pф/page5.html

\footnotetext{
1 Филатов М.И., Подлевских А. П. Стенд для диагностики, ремонта и обкатки ДВС. Авторское свидетельство PФ RU2269106C2, Кл. G 01 M $15 / 00$ от 05.04 .2004 .

${ }^{2}$ Гуревич Д. Ф., Цырин А. А. Ремонтные мастерские совхозов и колхозов: Справочник. - Л.: Агропромиздат, Ленинградское отделение, 1988.
}

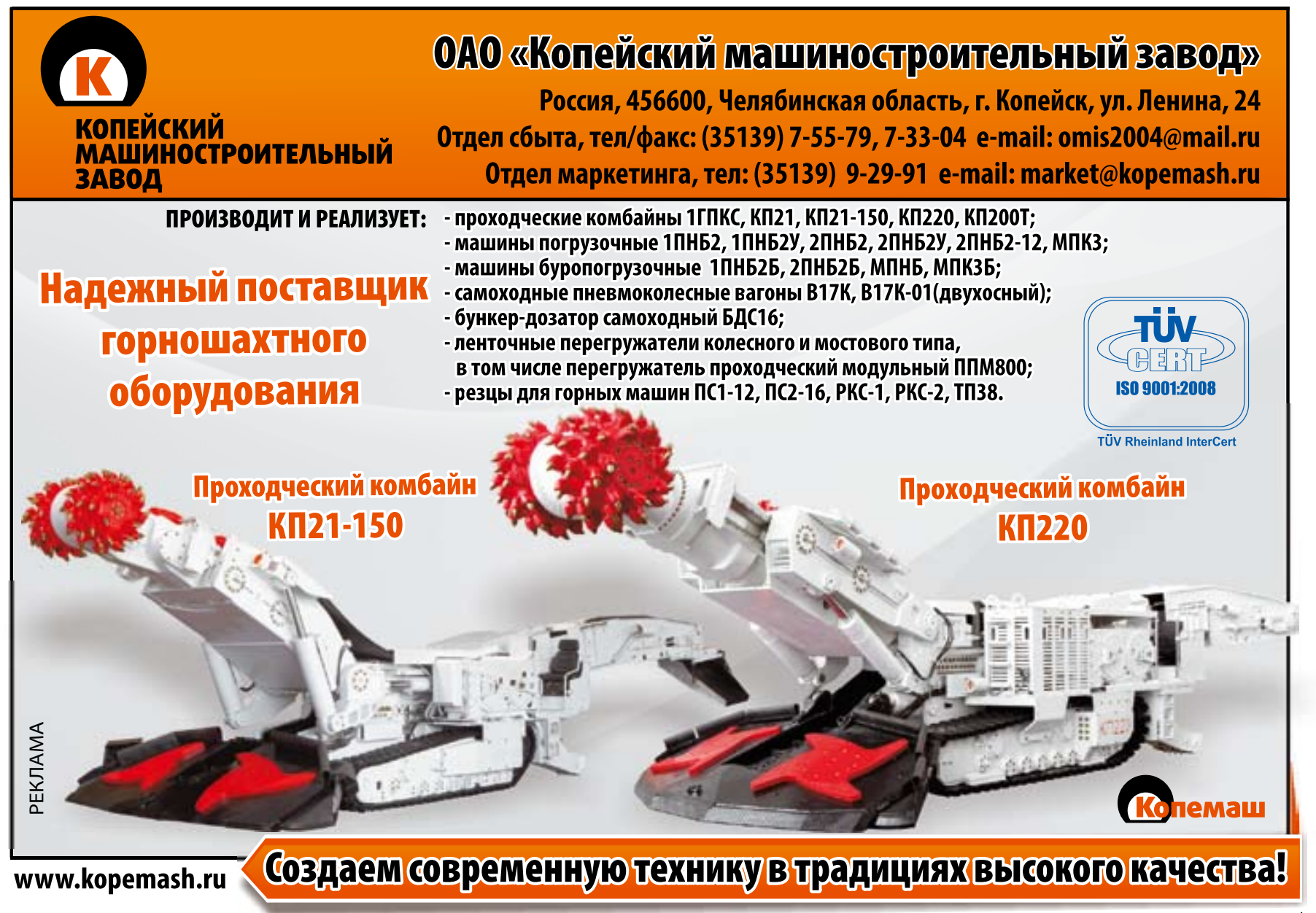




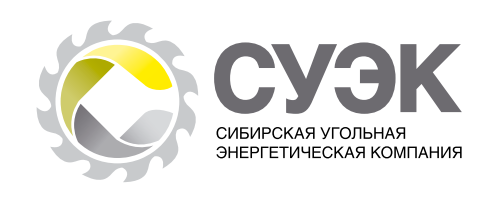

Наша справка

ОАО «Сибирская угольная энергетическая компания» (СУЭК) крупнейшее в России угольное объединение по объему добычи. Компания обеспечивает около $30 \%$ поставок угля на внутреннем рынке и примерно $25 \%$ российского экспорта энергетического угля. Филиалы и дочерние предприятия СУЭКрасположены в Забайкальском, Красноярском, Приморском и Хабаровском краях, Кемеровской области, в Бурятии и Хакасии.

Около трети от общего объема угледобычи СУЭК обеспечивает ленинск-кузнецкое подразделение компании - ОАО «СУЭК-Кузбасс». В состав компаниивходят девять шахт, три угольных разреза, три обогатительных фабрики и 16 вспомогательных предприятий. Добыча ОАО «СУЭК-Кузбасс» за 2013 г. составила 32,6 млн т, что на 1,6 млн т больше, чем в 2012 г.

\section{В компании «СУЭК-Кузбасс» открыто собственное производство сетки} для крепления горных выработок

В ООО «Сиб-Дамель» (г. Ленинск-Кузнецкий) - сервисном предприятии ОАО «СУЭК-Кузбасс» - введен в эксплуатацию цех по производству сетки для крепления горных выработок.

Всего за три месяца было создано современное производство по выпуску сетки для крепления горных выработок с автоматической многоточечной линией контактной сварки. Стоимость приобретенного оборудования составляет 15 млн руб.

Как рассказал директор ООО «Сиб-Дамель» Николай Жалнин, преимущества данного устройства в более высоком уровне автоматизации, позволяющем снизить человеческий фактор, повысить качество и сократить себестоимость готовой продукции.

Используется уникальная технология подачи продольных прутков, разработанная в научно-производственном объединении «Росстройтех» (г. Новосибирск). Она позволяет сваривать сетки без остановки процесса на зарядку прутков. Базой многоточечной линии является сварочный портал, оснащенный модулем подачи поперечных прутков.

Сегодня в среднем за смену изготавливается порядка 150 сеток. Планируется, что вскоре рядом с уже действующей линией появится аналогичная вторая. Цель - выйти на годовой объем один миллион квадратных метров сетки. Это позволит полностью обеспечить потребности шахт компании в таком виде крепления и продавать оборудование сторонним угольным предприятиям.

В перспективах развития ООО «Сиб-Дамель» предусматриваются также установка линии по производству штрипсов-пластин для крепления горных выработок и освоение изготовления усиленной шахтовой затяжки.

\section{Новая схема сборки ленточного конвейера увеличит срок службы техники в полтора раза}

Дивизион инфраструктурных проектов Corum при изготовлении ленточного конвейера для ключевого клиента - ДТЭК применил новую схему сборки приводного блока. Отметим, что применение в сборке блока коническо-цилиндрических редукторов позволит увеличить срок службы техники в полтора раза. Схема с использованием редукторов данного типа также позволила достичь минимальных габаритных размеров приводной установки, уменьшить затраты времени на монтаж оборудования.

С целью повышения надежности узлов и конвейера в целом, а также для обеспечения необходимых пусковых и тормозных режимов в сложных условиях эксплуатации специалисты компании Corum при изготовлении оборудования применили комплектующие нового поколения.

По словам директора Дивизиона инфраструктурных проектов Corum Group Владимира Мерзликина, повышение требований к технике стимулирует рост ин-

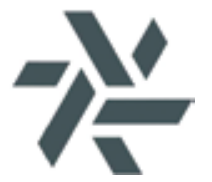

женерной мысли и инноваций у производителя. «Наша компания идет по пути непрерывных улучшений технических характеристик оборудования, и последняя разработка - еще один наглядный тому пример», - подчеркнул В. Мерзликин.

\section{Наша справка}

Компания Corum (ранее НПК «Горные машины») входит в состав крупнейшей в Украине финансово-промышленной группы «Систем Кэпитал Менеджмент» (СКМ) и является экспертом в горнодобывающем бизнесе. Деятельность компании сосредоточена на предоставлении высокотехнологичных комплексных решений, производстве и сервисе оборудованияв области добычи, переработки итранспортировки полезных ископаемых, а также строительстве шахт. В Corum входят шесть заводов в Украине, ремонтные площадки в Украине и России, торговые компании в Украине, России, Казахстане, Вьетнаме и Польше. Сайт компании: www. corum. com. 


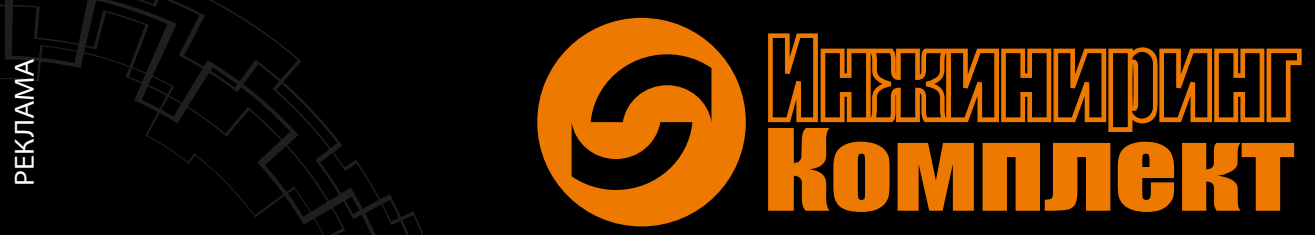

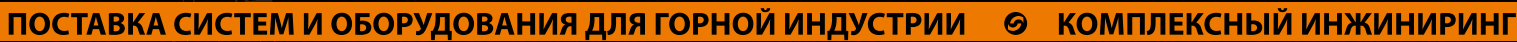

До 5 испытаний в год

Обособленных подразделений из регионов РФ и стран СНГ

Более 12000 наименований предлагаемого

оборудования из 17 стран мира

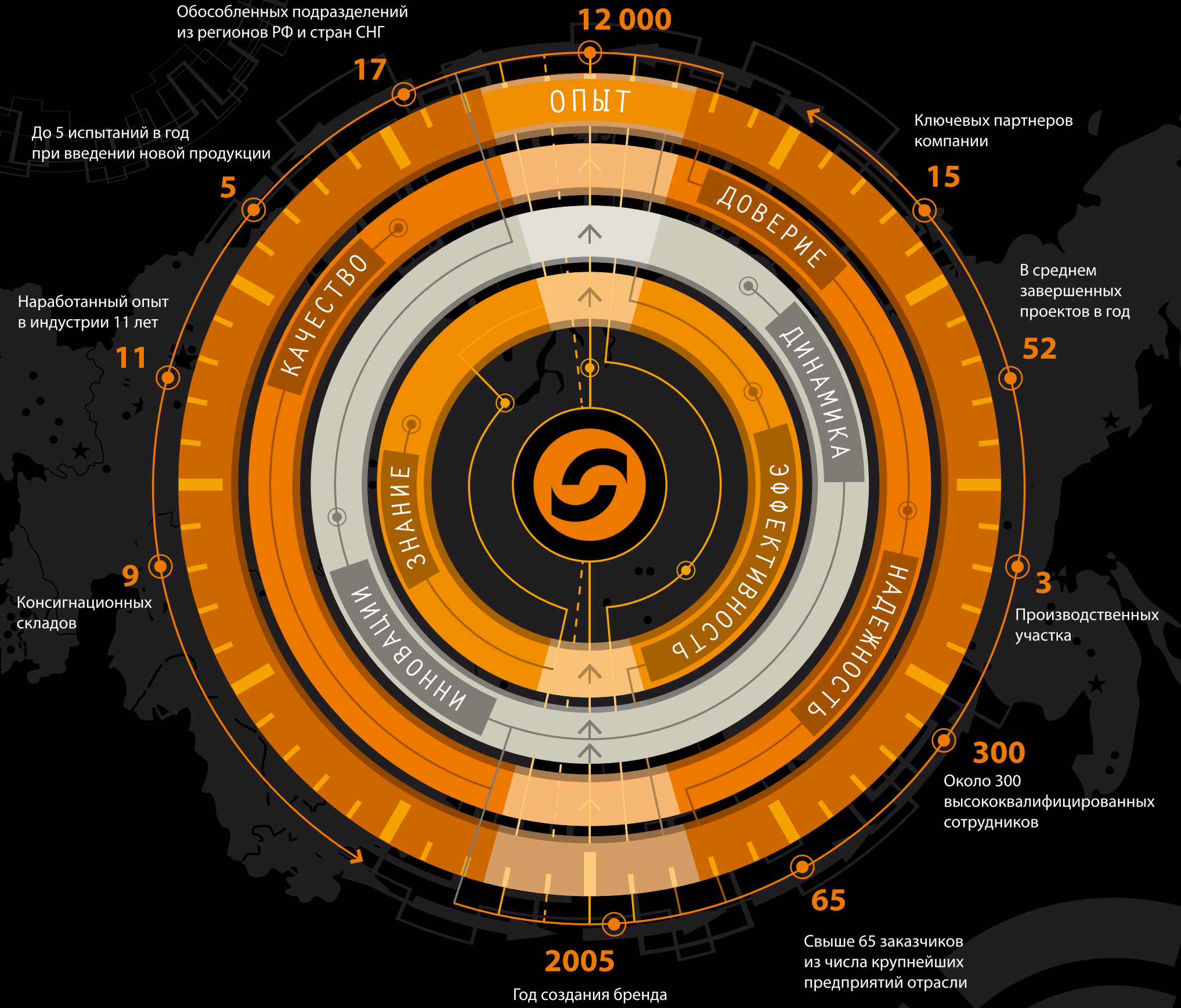

«Инжиниринг Комплект» - ведущий поставщик комплексных решений и услуг по инженерному проектированию, поставке и обслуживанию надежного оборудования для горнодобывающей, металлургической и энергетической промышленностей. 


\section{НОвого высокотехНологиЧного завода по проивводству смазочных и сопутствующих материалов FUCHS}

19 сентября 2013 г. в Калуге состоялось официальное открытие нового современного завода компании FUCHS nо производству смазочных и сопутствующих материалов.

На церемонии открытия завода присутствовали губернатор Калужской области Анатолий Артамонов, председатель правления FUCHS PETROLUB SE Стефан Фукс и руководство компании, представители Администрации Калужской области, представители федеральных ведомств Российской Федерации в Калужской области и деловые партнеры компании FUCHS.

Строительство завода было начато в 2011 г., и 6 течение двух лет был построен завод, оснащенный современным, высокопроизводительным инновационным технологическим оборудованием. Суммарные инвестиции в проект составили более 15 млн евро, производительность нового завода составляет до 40 тыс. т продукции в год.

Предприятие, отвечающее самым высоким стандартам в области качества выпускаемой продукции, безопасности труда и экологии, уже производит широкий спектр смазочных материалов промышленного (гидравлические масла, смазочно-охлаждающие средства для резки и шлифовки металлов, компрессорные масла и др.) и автотранспортного назначения (моторные масла, масла для коробок передач и трансмиссий, амортизаторные жидкости).

Филиалы компании открыты в Москве, Ярославле, Екатеринбурге, Санкт-Петербурге, всего на территории России трудятся более 70 человек, а в мире это более 50 дочерних предприятий с общей численностью более 4000 человек. Как в годы становления компании, так и сегодня деятельность группы FUCHS отличается инновационным подходом и высоким уровнем специализации.

Ориентация на разработку новых специализированных и созданных для конкретного заказчика смазочных материалов является приоритетом в корпоративной политике компании FUCHS, поэтому оборудованный по последнему слову техники завод FUCHS в Калуге имеет химическую лабораторию, оснащенную высокотехнологичным оборудованием.

Специалисты компании «FUCHS» постоянно работают в тесном сотрудничестве с ведущими предприятиями, производителями горнодобывающей техники. Постоянное увеличение нагрузки на очистное и проходческое оборудование, работа оборудования в условиях запыленности и повышенной влажности требуют применения смазочных материалов с повышенными требованиями.

Результатом стало появление смазочных материалов, разработанных специально для тяжелых условий эксплуатации, и прочзводство навновь открывшемся заводе в г. Калуга:

- Масла семейства POWERGEAR подходят для использования в мощной технике, включая очистные и проходческие комбайны, приводы скребковых конвейеров, дробилок, перегружателей. Продукты POWERGEAR также успеш-

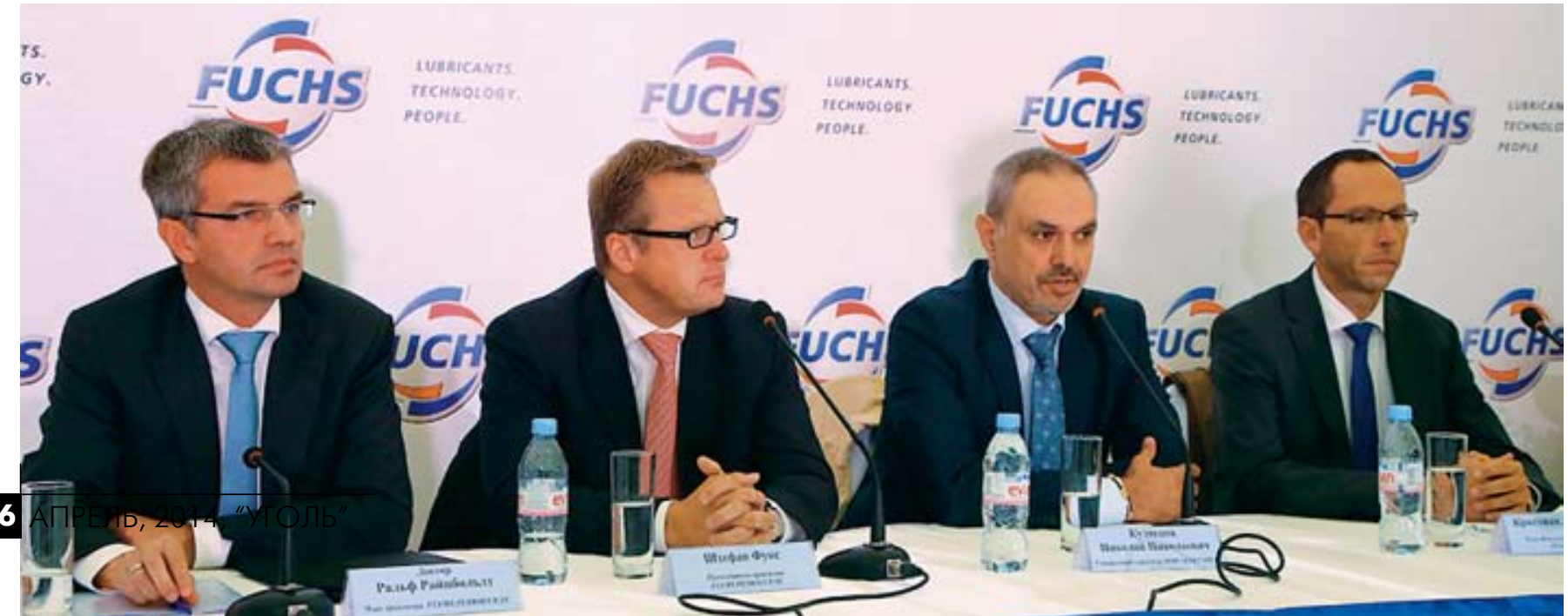


но применяются в тяжелонагруженных промышленных редукторах, позволяя сократить спектр применяемых смазочных материалов. В состав масел также введены присадки, эмульгирующие воду и загрязнение, что обеспечивает эффективную работу техники в условиях высокой влажности и запыленности.

- Масла RENOLIN MR рекомендуются для оборудования, эксплуатирующегося в условиях сильных колебаний температуры, что вызывает образование конденсата, и в условиях запыленности. Если оборудование не может быть доставлено заправленным рабочей жидкостью, даже пленка, оставшаяся после обкатки на RENOLIN MR, обеспечивает достаточную антикоррозионную защиту.

- Применяемая технология присадок придает маслу POWERDRAULIC рабочие характеристики, как правило, недостижимые для гидравлических масел на минеральной основе. В угольных шахтах эксплуатация оборудования в условиях сильной запыленности и влаги является нормой. Масло POWERDRAULIC сохраняет работоспособность в присутствии значительного количества загрязнений, а также способно эмульгировать воду.

Всю необходимую сопроводительную информацию по вышеперечисленным смазочным материалам можно получить по тел.: +7 (495) 961-27-41, или отправив запрос по e-mail: info-mos@fuchs-oil.ru
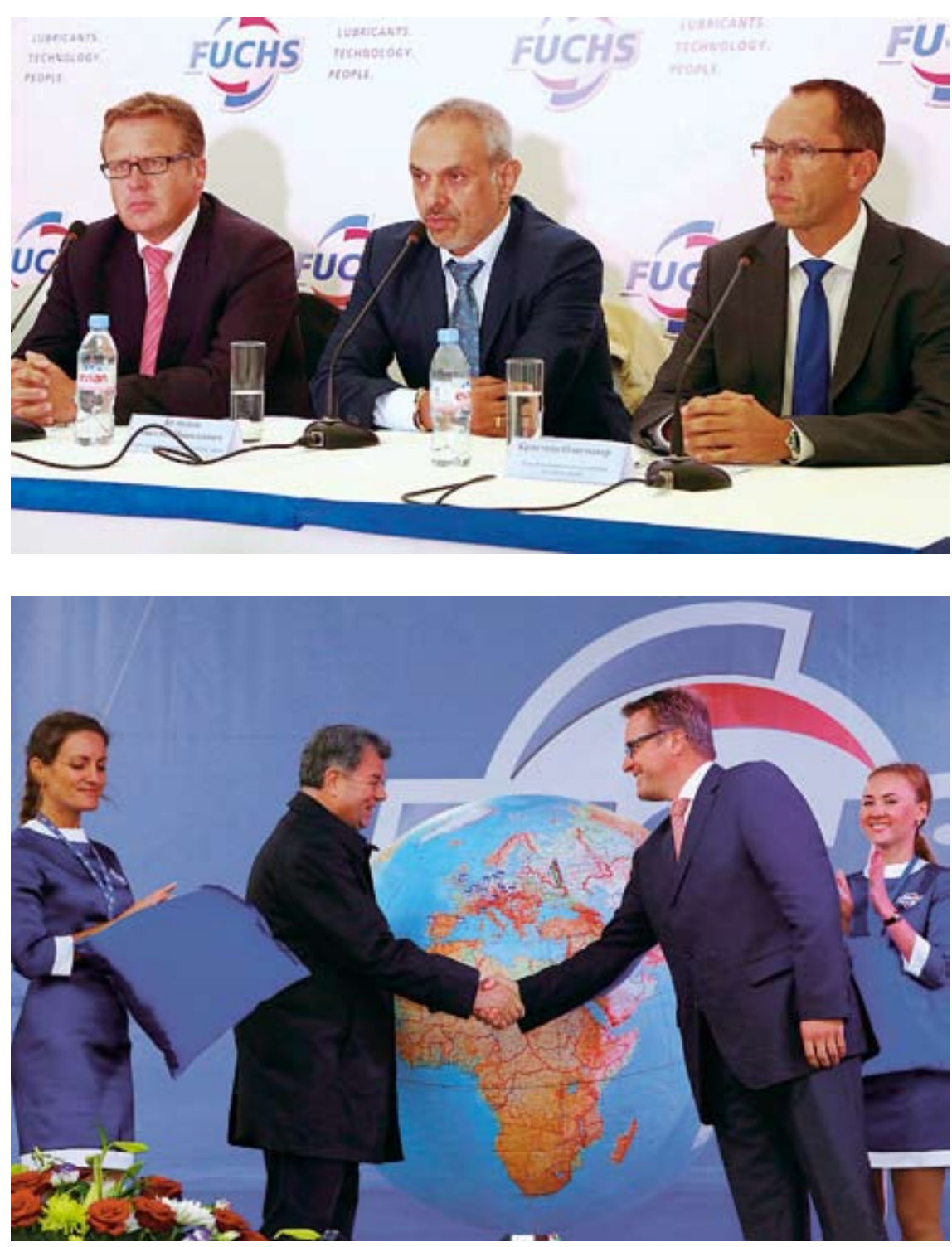

\section{ООО «ФУКС ОЙЛ»}

125252, Москва, ул. Авиаконструктора Микояна, 12 Тел: +7 (495) 961-27-41. Факс: +7 (495) 961-01-90
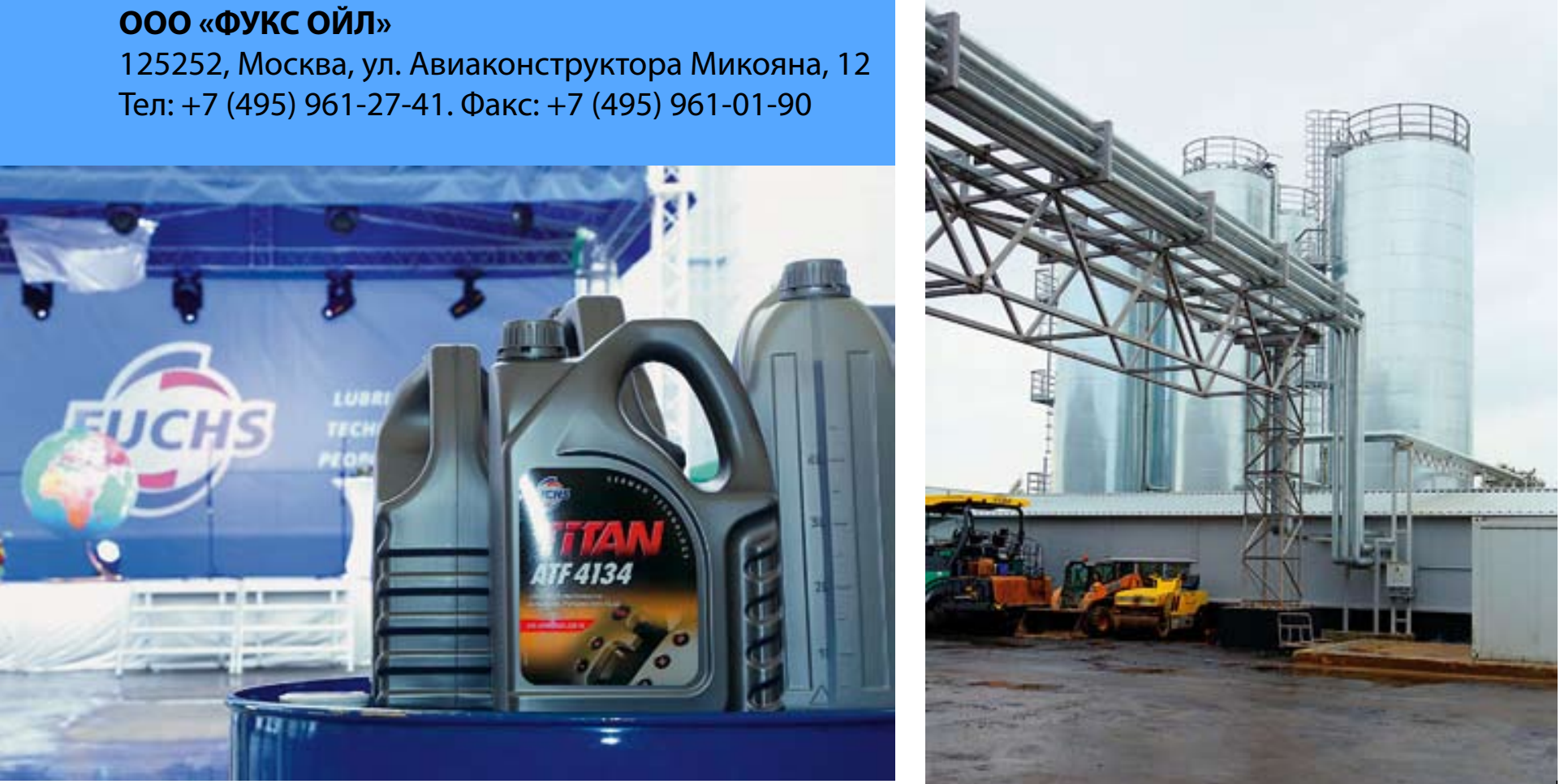


\section{Расширение области применения}

\section{метода направленного гидроразрыва (НГР)}

\section{ЛЕКОНЦЕВ Юрий Михайлович \\ Старший научный сотрудник ИГД СО РАН им Н. А. Чинакала, \\ канд. техн. наук}

\section{САЖИН Павел Васильевич}

Научный сотрудник ИГД СО РАН им Н. А. Чинакала, канд. техн. наук

\section{САЛИХОВ Альберт Фидаилович}

Директор шахты «Березовская»

ОАО «Угольная компания «Северный Кузбасс»

\section{ИСАМБЕТОВ Вячеслав Фаритович}

Главный инженер шахты «Березовская»

ОАО «Угольная компания «Северный Кузбасс»

В статье описана технология применения метода гидроразрыва для повышения эффективности склеивания массива горных пород, склонного к образованию заколов и куполов по груди забоя на шахте «Березовская», а также приведены некоторые результаты экспериментальных исследований.

Ключевые слова: гидроразрыв, смола, упрочнение массива, куполообразование.

Контактная информация:

e-mail:pavel301080@mail.ru;

al.salikhov@mail.ru;

isambetov@gmail.com

Гидрорасчленение, «слепой» или неконтролируемый гидроразрыв, направленный гидроразрыв (НГР) широко известные способы разупрочнения угольного массива и вмещающих пород [1-4]. При этом основные задачи гидровоздействия сводятся к снижению нагрузок на горные выработки, сокращению шага первичной посадки, повышению газоотдачи угольных пластов.

На шахте «Березовская» впервые направленный гидроразрыв был применен как вспомогательный технологический прием, повышающий эффективность и расширяющий область применения скрепляющих породные массивы неньютоновских жидкостей, в частности смол, с целью скрепления легкообрушающихся кровель и снижения куполообразования.

Шахта «Березовская» отрабатывает пологий угольный пласт XXVI длинными столбами по простиранию струговым комплексом DBT (в частности лавой №42). Длина лавы №42 составляет 296 м, мощность угольного пласта - 0,9-1,1 м.

Первые проблемы во время отработки пласта стали возникать после отхода лавы №42 на 60 м от монтажной камеры. Периодически стали происходить локальные куполообразования по груди забоя. По длине забоя количество куполообразований доходило до восьми с высотой 1,2-1,4 м и протяженностью 4-5 м. Эти вывалы формировались, преимущественно, в средней части лавы на расстоянии примерно 7-10 м друг от друга в шахматном порядке с периодичностью через 10-20 м отхода лавы.

На рис. 1, а показана схема формирования куполообразования, а на рис. 1, 6 развитие этого процесса после двух-трех передвижек секции. Как видно из этих рисунков, процессу куполообразования в каждом случае предшествовало появление заколов в кровле и угольном массиве по груди забоя.
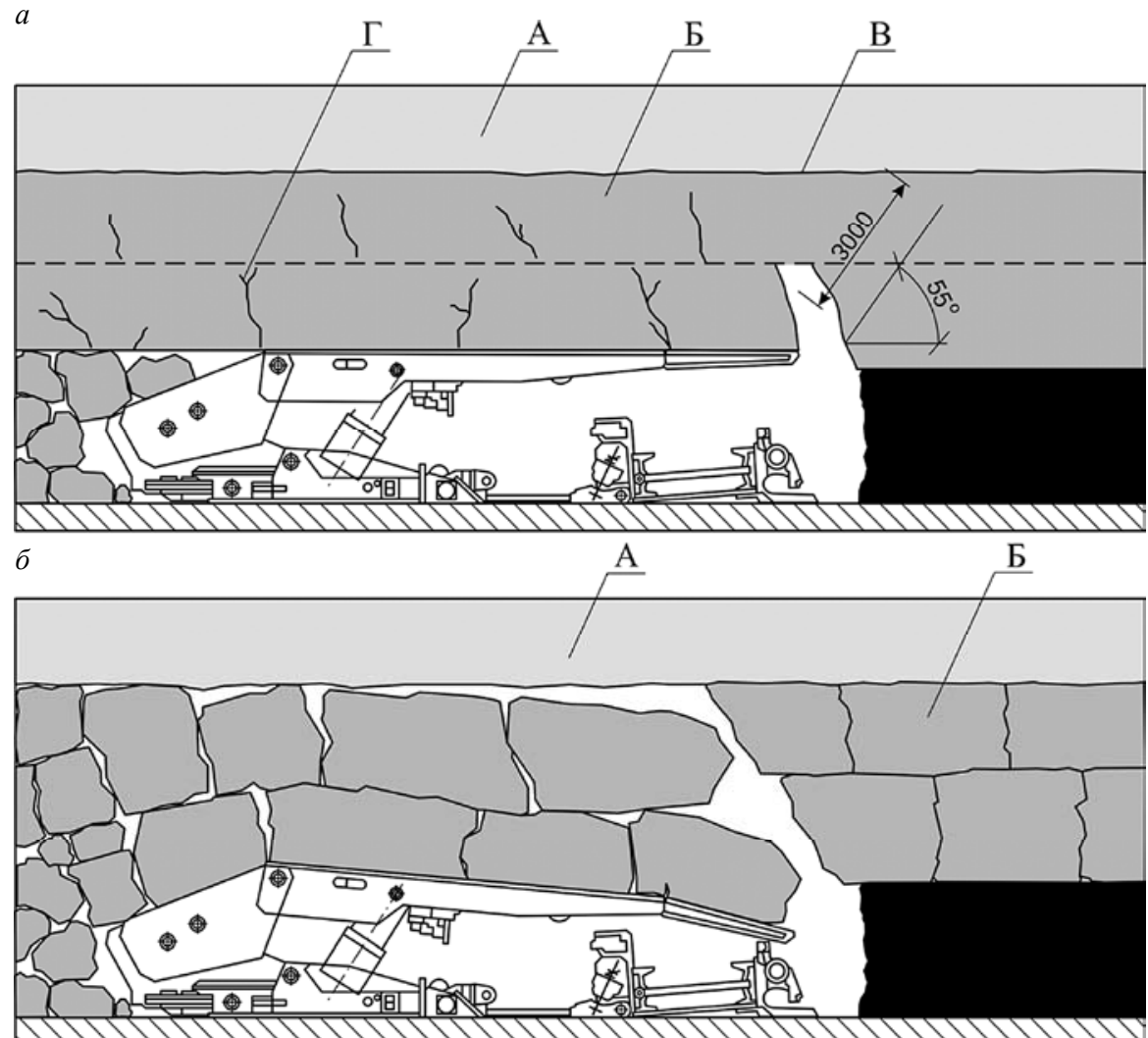

Puc. 1. Схема образования и развития куполов 


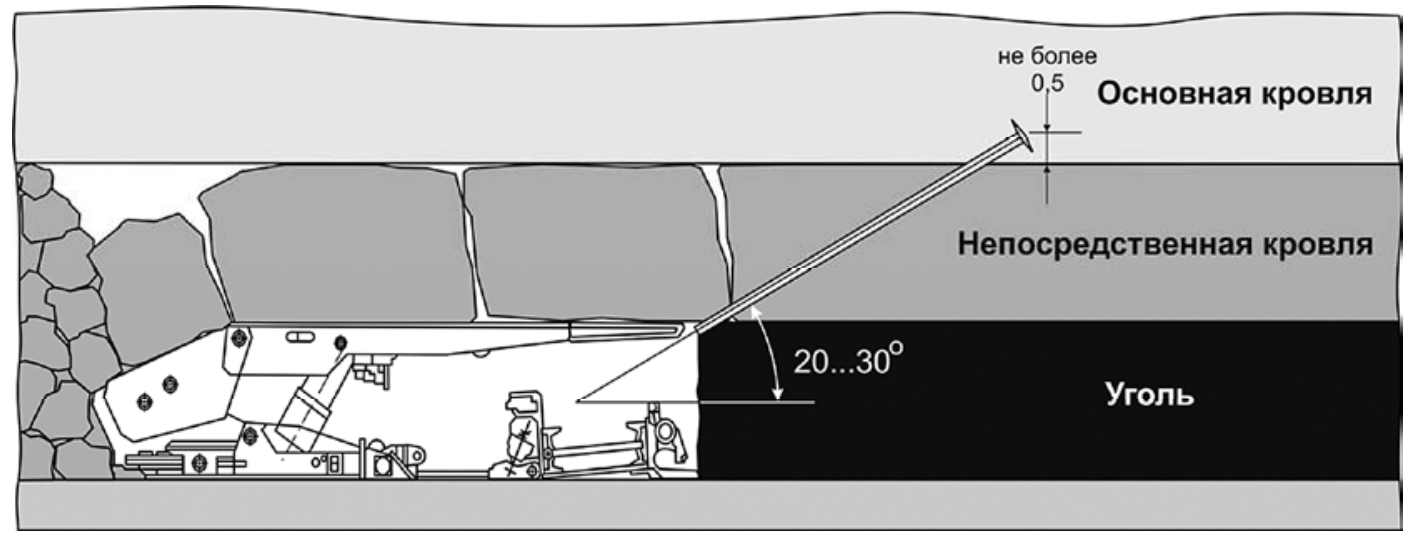

Puc. 2. Схема заложения шпуров для проведения гидроразрывов

Попытки превентивного оперативного закрепления смолой непосредственной кровли (а именно в ней происходит процесс куполообразования) заканчивались безрезультатно, так как смола не продавливалась в кровлю через пробуренные шпуры, выполненные в местах предполагаемых вывалов породы.

Анализ результатов работ по закреплению пород кровли смолой показал, что смола, обладая значительной вязкостью, не проникает в естественные трещины непосредственной кровли, так как последняя имеет крупноблочное строение, следовательно, вероятность пересечения пробуренного шпура с естественными трещинами весьма мала.

Кроме того, нагнетание смолы усложняется тем, что буримые под углом к горизонту шпуры невозможно остановить в плоскости контакта между основной и непосредственной кровлями (поз. «В» на рис. 1, a). Забойная часть шпура может не дойти до этой плоскости или перейти ее, углубляясь в основную кровлю. В обоих этих случаях давление нагнетания смолы должно превысить прочностные свойства вмещающих пород для проникновения в плоскость «В» (по экспериментальным исследованиям 25-30 МПа). Оборудование для нагнетания вязких составов в массив под высоким давлением в настоящее время не разработано.

Исходя из этого, встал вопрос об искусственном создании необходимых условий для возможного нагнетания скрепляющих растворов в плоскость «В»- контакта основной и непосредственной кровель, и далее по ней до естественных трещин (поз. «Г» на рис. 1, a) для склеивания и упрочнения блоков (по теоретическим предположениям, смола должна проникать в эти трещины независимо от пересечения их шпуром).

Сотрудниками ИГД СО РАН совместно с работниками шахты «Березовская» была предложена технология гидроразрыва, способная создавать искусственную протяженную трещиноватость в породных массивах. Схема заложения экспериментальных шпуров по предложенной технологии показана на рис. 2.

Шпуры бурились под углом а из расчета захода его забойной части, примерно, на 0,5 м в основную кровлю. При этом длина шпуров составляет 6-10 м. Последний параметр увязывался с техническими характеристиками гидрооборудования и буровой установки.

Заход шпура в основную кровлю гарантировал выход гидроразрыва в плоскость «В» и проникновение закрепляющей смолы в межблочные трещины «Г».

Гидроразрыв осуществлялся по отработанной в ИГД СО РАН технологии. Отличие заключалось во времени нагнетания жидкости после гидроразрыва (увеличилось до 10-15 мин) За счет этого обеспечивались промывка и расширение устьев искусственных и естественных трещин, что повышало доступ в них смолы. На рис. 3 показано

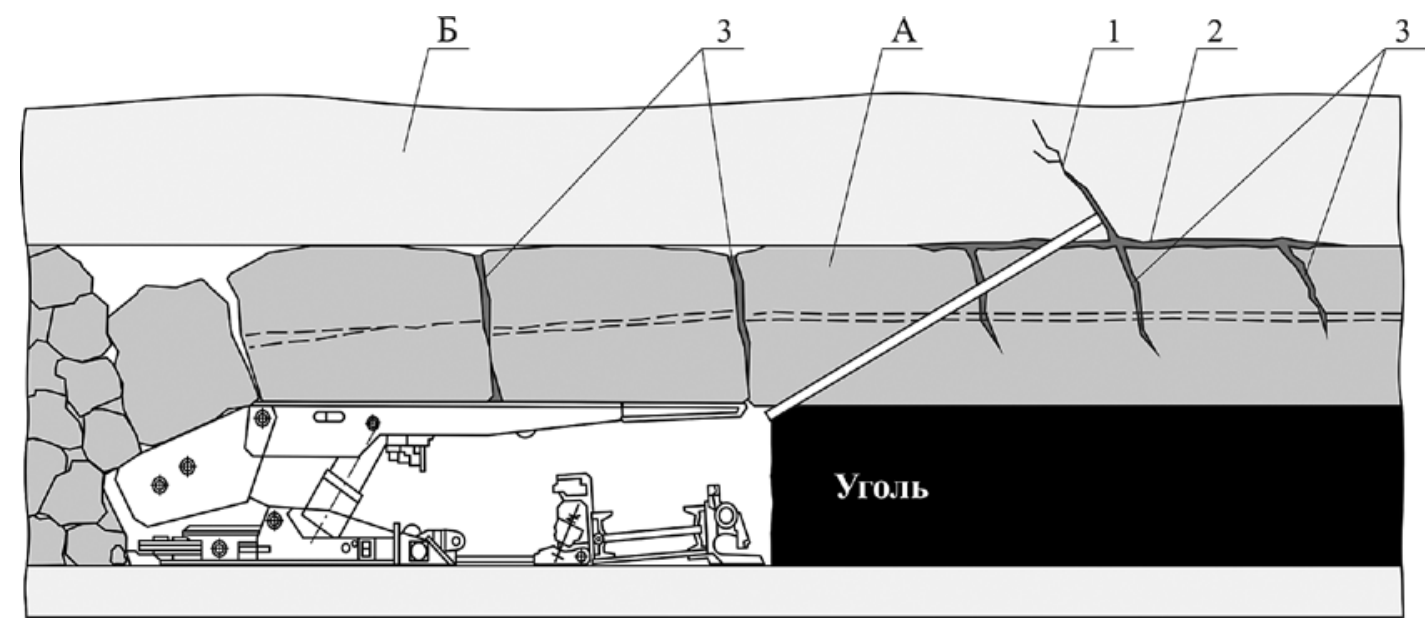

Puс. 3. Проникновение скрепляющей смолы в массив 


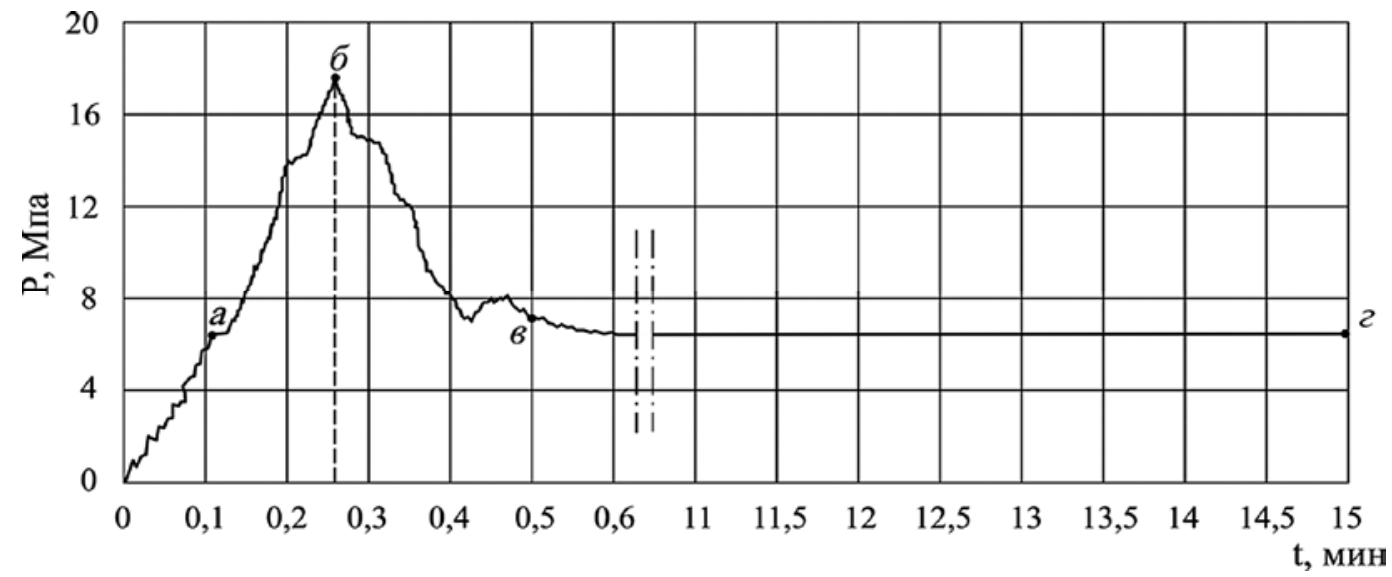

Puс. 4. Запись прочесса гидроразрыва горного массива

\section{Время нагнетания рабочей жидкости в шпур после проведения гидроразрыва и его влияние на объем нагнетаемых скрепляющих веществ}

\begin{tabular}{|c|c|c|c|}
\hline $\begin{array}{c}\text { Время нагнетания рабочей } \\
\text { жидкости в шпур } \\
\text { после гидроразрыва, мин }\end{array}$ & $\begin{array}{c}\text { Количество } \\
\text { смолы, см }\end{array}$ & $\begin{array}{c}\text { Время нагнетания } \\
\text { смолы, мин }\end{array}$ & Примечания \\
\hline 10 & 30000 & 12 & Смола вышла через трещины над забоем \\
\hline 15 & 35000 & 10 & Смола вышла через трещины над забоем \\
\hline 20 & 35000 & 10 & Смола вышла через трещины над забоем \\
\hline
\end{tabular}

проникновение смолы после проведения гидроразрыва во все искусственные 1 и естественные 2, 3 трещины, что подтвердилось отпечатками последней на обрушенных блоках в радиусе 10-12 м от шпура.

Проведенные шахтные эксперименты по предложенной технологии показали высокую эффективность предложенного метода. Все предполагаемые, по прогнозу, очаги куполообразования после проведения гидроразрывов с последующим нагнетанием связующих составов были пройдены со значительным снижением простоя крепи по причинам ликвидации последствий вывалов (в среднем на 6-8 ч).

На рис. 4 приведена характерная запись изменения давления рабочей жидкости при проведении гидроразрыва в одной из скважин.

При этом давление гидроразрыва в отдельных шпурах достигало $21 \mathrm{MПа,} \mathrm{а} \mathrm{среднее} \mathrm{значение} \mathrm{по} \mathrm{скважинам} \mathrm{-}$ 17 МПа.

Из записи видно, что основной процесс гидроразрыва длится, примерно, тридцать - сорок секунд после начала нагнетания рабочей жидкости (см. участок «о-в» рис. 4). Эта величина может варьироваться в зависимости от физикомеханических свойств массива. Дальнейшее нагнетание происходит при постоянном давлении (см. участок «в-г» рис. 4) и позволяет расширить устья существующих естественных 2, 3 и созданных искусственных 1 трещин (см. рис. 3) и, как следствие, повысить их проницаемость для скрепляющих растворов. Результаты экспериментов о времени нагнетания рабочей жидкости в шпур после проведения гидроразрыва и влияние этого показателя на объем нагнетаемых скрепляющих веществ представлены в таблице.

Результаты экспериментов показали высокую эффективность комплексной технологии для придания породному массиву необходимых прочностных свойств.

\section{Выводы}

1. Составы неньютоновских жидкостей, склеивающие массивы горных пород, имеют ограниченную область применения из-за низкой проницаемости (высокой вязкости).

2. Процесс трансформации давления неньютоновской жидкости от нагнетательной установки в массив значительно растянут во времени и характеризуется большими потерями давления по длине скважины, что не позволяет им проникать в естественные протяженные микротрещины.

3. Эффективность склеивания крупноблочных массивов, а также массивов с естественной микротрещиноватостью, склонных к формированию заколов и куполообразований по груди забоя, можно повысить путем предварительного гидровоздействия.

\section{Список литературы}

1. Леконцев Ю. М., Сажин П. В., Ушаков С. Ю. Применение метода поинтервального гидроразрыва для разупрочнения породного прослойка в угольном пласте // ФТПРПИ. №3. - 2012. - С. 135-144.

2. Сажин П. В., Леконцев Ю. М. Применение метода направленного гидроразрыва // ФТПРПИ. - 2008. - №3.

3. Клишин В. И., Леконцев Ю. М. Средства реализации безвзрывного разрушения горных пород растягивающими усилиями // Тр. Междун. конф. «Проблемы и перспективы развития горных наук», Т. ІІ. Машиноведение. Геотехнологии. - Новосибирск, 2006. С. $384-389$.

4. Клишин В. И., Леконцев Ю. М., Сажин П. В. Пути повышения эффективности метода направленного гидроразрыва // ФПФТГ. - Новосибирск, 2008. 


\section{Спецналадка ОАО «СУЭК-Кузбасс»}

ПРИГЛАШАЕТ К СОТРУДНИЧЕСТВУ

В системе сервисных предприятий ОАО «СУЭК-Кузбасс» Спецналадка является одним из наиболее универсальных. Мы способны предоставлять предприятиям компании и сторонним организациям до 500 видов услуг различного производственного спектра.

Ремонт и производство горношахтного оборудования:

- ремонт анкероустановщиков RAMBOR, CБР;

- ремонт и ревизия горношахтного оборудования (ГШО);

- изготовление несущих элементов монорельсовой дороги (секции, подвесы, комплектующие, стрелки и др.);

- изготовление контейнеров для перевозки грузов по подвесному пути дизельными локомотивами.

- изготовление рукавов высокого давления с резьбовым и быстроразъемным соединением.
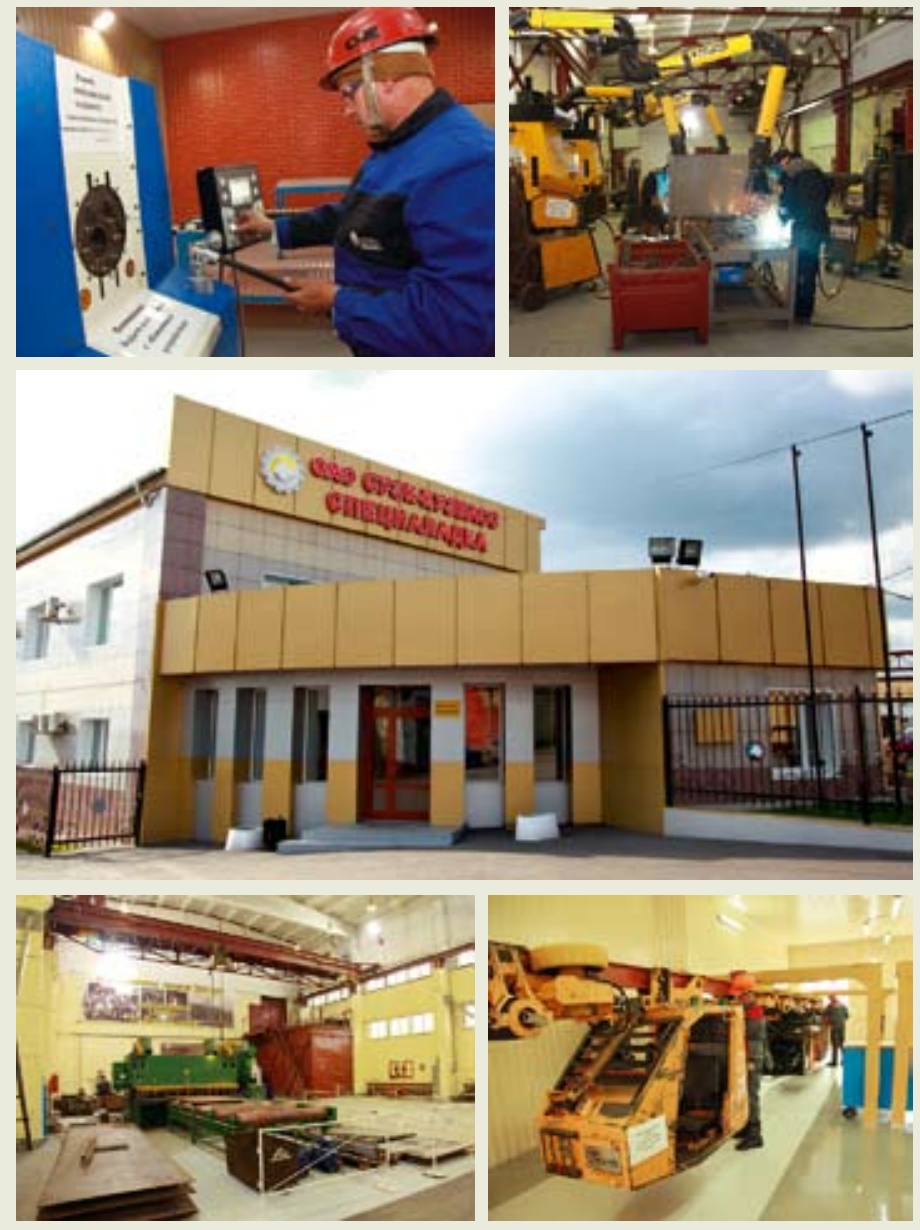

С 2014 г. номенклатура выпускаемой продукции значительно увеличивается благодаря приобретению профилегибочного станка и станка плазменной резки. Они позволяют изготавливать изделие разной конфигурации.

Ревизионно-наладочные работы

горношахтного оборудования:

- ревизия, наладка, испытание и вибродиагностика стационарных установок: подъемных машин, вентиляционных установок; дефектоскопия ГШО;

- ревизия, наладка, испытание аппаратуры «Метан», высоковольтного оборудования, ТСВП;

- ревизия, наладка проходческих комбайнов, гидросистемы механизированных комплексов, магистральных конвейеров, аппаратуры управления конвейеров АУК, аппаратуры телемеханики «Ветер»;

- измерения в электрических сетях до 10 кВ;

- анализ проб масел;

- проверка взрывобезопасности низковольтного оборудования;

- ремонт приборов безопасности, газоанализаторов М-2;

- сопровождение программного обеспечения автоматизированных систем управления на эксплуатируемых и вновь строящихся обогатительных фабриках.

Монтаж-демонтаж горношахтного оборудования:

- монтаж-демонтаж механизированных комплексов, ленточных конвейеров и монорельсового пути, а также электро- и гидромонтажные работы. Для сокращения сроков успешно используются пневматические анкеропосадочные станки (RAMBOR, CБP), подземные краны-тягачи «Petitto Mule» (США).

Теплосиловое хозяйство щахт включает:

- пылегазоулавливающие установки по очистке выбросов в атмосферу;

- систему аспирации, насосно-фильтровального и сварочного оборудования, приборов учета тепловой и электрической энергии.

На предприятии созданы участки:

- ремонта (включая капитальный) и обслуживания дизелевозов;

- транспортировки людей и грузов подвесными дизель-гидравлическими локомотивами в глубинах шахт.
МЫ БУДЕМ РАДЫ СОТРУДНИЧЕСТВУ С НОВЫМИ ПРЕДПРИЯТИЯМИ И КЛИЕНТАМИ. ГОТОВЫ В УДОБНОЕ ДЛЯ ВАС ВРЕМЯ ОБСУДИТЬ ВСЕ УСЛОВИЯ И ПРЕДЛОЖЕНИЯ.

\section{ОАО «СУЭК-Кузбасс» Спецналадка}

Кемеровская обл., г. Ленинск-Кузнецкий, ул. Фурманова, 25

Тел. /факс: +7(38456) 2-77-67

e-mail: specnaladka@suek.ru

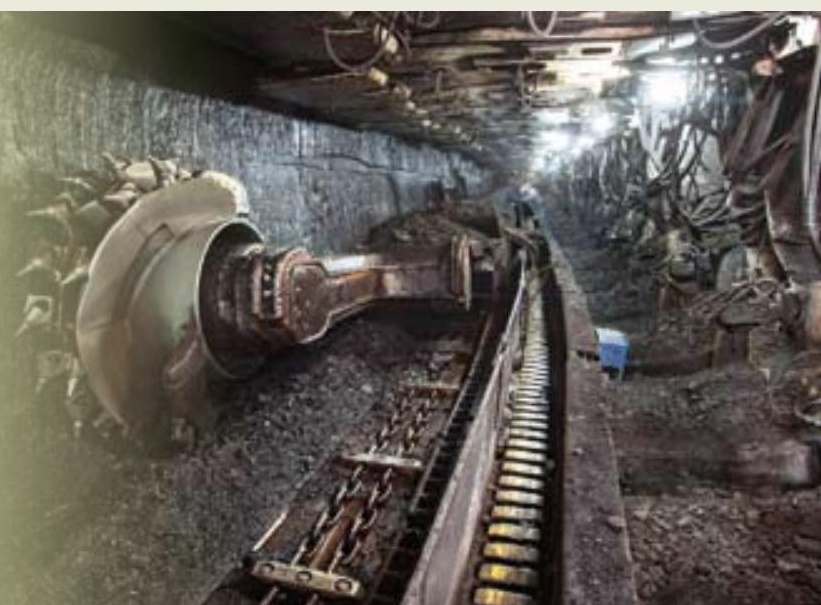


Крупнейший частный банк Латвии Rietumu - практически единственный банк в регионе Балтии, на протяжении многих лет настойчиво и целенаправленно развивающий направление торгового финансирования. Среди его клиентов - трейдеры, ведущие торговлю сырьем, продуктами аграрного сектора и промышленными товарами по всему миру.

О возможностях и опыте Rietumu в обслуживании международных торговых операций рассказывает руководитель Отдела торгового финансирования банка Наталья ПЕРХОВА.

\section{Банк Rietumu:}

\section{мы финансируем движение товара}

\section{от закупки до реализации}

Почему Rietumu уделяет столь серьезное внимание развитию торгового финансирования?

- Это направление мы создали у себя давно, но более активно начали развивать его в разгар экономического кризиса 2008 г., и действительно, в определенном смысле двигались против тенденций рынка. Многие банки в тот момент как раз сворачивали такие услуги, мы же определенно видели в этой сфере новые возможности и перспективы. По сути, мы следовали за нашими клиентами, за их бизнесом, стремились предугадать их потребности, К тому моменту у нас уже был неплохой опыт в данной сфере, и здесь он особенно важен, ведь торговое финансирование отличается от классического кредитования и имеет очень серьезную специфику. Необходимо понимание рынка и происходящих процессов, знания в смежных отраслях - логистика, страхование, международная торговля; не менее важны и доверительные партнерские отношения с клиентами.

Торговое финансирование - краткосрочное финансирование оборотного капитала компании-торговца - было и остается востребованным. В международной торговле капиталоемкими товарами, такими как нефть и нефтепродукты, уголь, иные виды сырья и сырьевых полуфабрика- тов, зерновые и т. п., объемы сделок велики, и большинство трейдеров при наличии у них такой возможности охотно используют привлеченные оборотные средства.

Могу сказать, что мы удовлетворены сотрудничеством с нашими клиентами и намерены развивать это направление и в дальнейшем. У торгового финансирования отличный потенциал - в этой сфере просто нужно уметь работать.

Кто ваши целевые клиенты, каким образом происходит их финансирование?

- Наш клиент - это торговая компания с годовым оборотом от 15 до 200 млндол. США. Это трейдер, ведущий международную торговлю, можно назвать его также посредником в подобных сделках. Как правило, он имеет дело с покупателем и продавцом, находящимися в разных странах, а может быть, и вообще в разных концах света. На практике торговая компания обычно не обладает какими-либо существенными активами, вроде недвижимости или основных средств производства. Ее основной «актив» - это понимание рынка, налаженные контакты с покупателями и продавцами, умение подготовить, заключить и выполнить сделку и т. п. В свою очередь банк, понимая бизнес клиента, качество его контрагентов и логистическую 
цепочку, выстраивает схему финансирования, позволяющую контролировать товар и выручку. Здесь возможны разные варианты и схемы организации сделки, которые зависят в том числе от потребностей нашего клиента.

Часто при экспортно-импортных сделках финансирование начинается с портового терминала, где груз уже складирован и подготовлен для экспорта. В этот момент банк предоставляет финансирование под залог товара, понимая, что далее он будет отгружен в адрес заранее согласованного с банком покупателя. Морской транзит при этом может быть достаточно кратким, а может занимать до 30-45 дней, и весь этот период клиент пользуется заемными средствами, предоставленными банком. Затем, по получении оплаты от покупателя, кредит погашается.

В принципе, мы можем финансировать движение товара непосредственно от его закупки до конечной реализации. Например, если поставщик готов поставить товар только при условии предоплаты, а покупатель при этом требует отсроченного платежа. Оценив кредитные риски покупателя и продавца, банк может софинансировать предоплату, финансировать товар во время транзита, а также продлить финансирование на срок отложенного платежа.

Что при этом нужно учитывать? Какие требования выдвигаются банком к клиентам?

- Любое сотрудничество, конечно же, начинается с общения с клиентом. Для банка важно прежде всего получить четкое понимание об опыте клиента в торговле тем или иным товаром или сырьем, масштабе торговых операций, специфике товара, оценить риски поставщиков и покупателей, понять схему движения груза. Анализируя движение товара и денег, банк идентифицирует риски и пытается их нивелировать имеющимся набором инструментов - страховка, хеджирование, использование аккредитивов и гарантий и т.п.

Поскольку на протяжении всего пути товар находится в залоге у банка, нужно считаться с тем, что во время кредитования торговой сделки между клиентом и банком происходит интенсивный обмен документами. Банк должен всегда располагать информацией о том, где и когда произошла отправка груза, кто является перевозчиком, на каком терминале товар хранится; перемещения груза должны подтверждаться соответствующими документами, накладными, коносаментами и т.д. К примеру, когда груз находится на портовом терминале, мы обычно заключаем трехсторонний договор, оговаривающий место хранения товара, выступающего в качестве залога, и обеспечение его сохранности.

Также привлекаем независимых экспертов, которые сертификатами могут подтвердить качественные и количественные характеристики груза, его специфические свойства. Например, для правильной оценки зерна важны такие параметры, как влажность, сорность, отсутствие ГМО, для угля - степень его энергоемкости (калорийности), для других грузов - иные характеристики, критично влияющие на качество и цену. Независимые эксперты помогают нам и в осуществлении мониторинга за залоговым товаром - благодаря этому мы в принципе можем финансировать торговые поставки через любой порт мира.

Товар на складе, а также в транзите страхуется в пользу банка. При разработке схемы финансирования мы ведем активный диалог с клиентом и страховщиками с целью по- добрать наиболее адекватное страховое покрытие, включающее в себя все риски в отношении данного товара.

В каких регионах преимущественно работают ваши клиенты?

- Наши клиенты занимаются экспортом грузов из России и других стран СНГ в Европу, Юго-Восточную Азию, Северную Африку и на Ближний Восток. Есть и обратные грузопотоки, скажем, импорт промышленных товаров и товаров народного потребления из Юго-Восточной Азии в СНГ.

Что касается торговых путей, то чаще всего мы финансируем грузы, которые транспортируются через порты Латвии, Литвы, Эстонии, через балтийские и черноморские порты России и некоторых других стран СНГ. Наши клиенты расширяют масштабы своей деятельности, выстраивают новые логистические цепочки, поэтому спектр постоянно расширяется. Пару лет назад, например, мы разработали схему финансирования через крупнейший европейский порт Роттердам.

Есть ли какой-то сопутствующий спектр банковских услуг, которые клиенты выбирают наряду сторговым финансированием?

- Торговые предприятия получают в Rietumu комплексный сервис, необходимый любой компании, занимающейся международным бизнесом. Это платежи, конвертация валют, хеджирование товарных и валютных рисков, документарные операции и т.д.

Поскольку мы стремимся выстраивать долгосрочные партнерские отношения, нередки случаи, когда владельцы и менеджеры компаний-клиентов сами становятся частными клиентами банка - размещают средства, оформляют ипотечные кредиты на покупку недвижимости в Латвии, получают при нашей поддержке европейский вид на жительство. У нас очень хорошие клиенты, и среди них достаточно много тех, кто работает с банком в течение 10-15 лет, и даже с самого основания Rietumu в 1992 г.

\section{Наша справка}

Rietumu - крупнейший частный банк Латвии, специализируется на обслуживании бизнеса и частных состояний. Помимо итаб-квартиры в Риге, представительства и партнеры банка действуют в Москве, Санкт-Петербурге, ряде других российских городов, а также в Киеве, Минске, Алматы, Ереване, Бухаресте, Париже, Шанхае.

По оченке делового журнала Business New Europe, Rietumu является лучшим банком Латвии. В конче 2013 г. Rietumu в третий раз стал лауреатом премиu SPEAR'S Russia Wealth Management Awards в номинации «Лучший банк в странах СНГ и Балтии, предоставляющий услуги частного банковского обслуживания и управления большими капиталами для российских клиентов» .
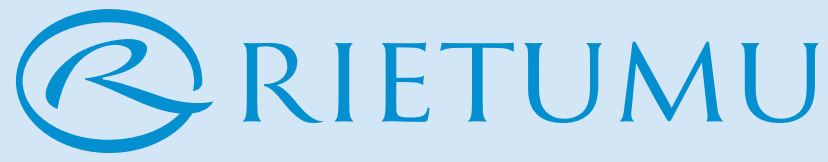

Более подробная информация: Тел. : +371 67025555.

E-mail: info@rietumu.Iv; credit@rietumu.Iv www. rietumu.ru 


\section{О функционале}

\section{исполнительного директора}

\section{угольного разреза}
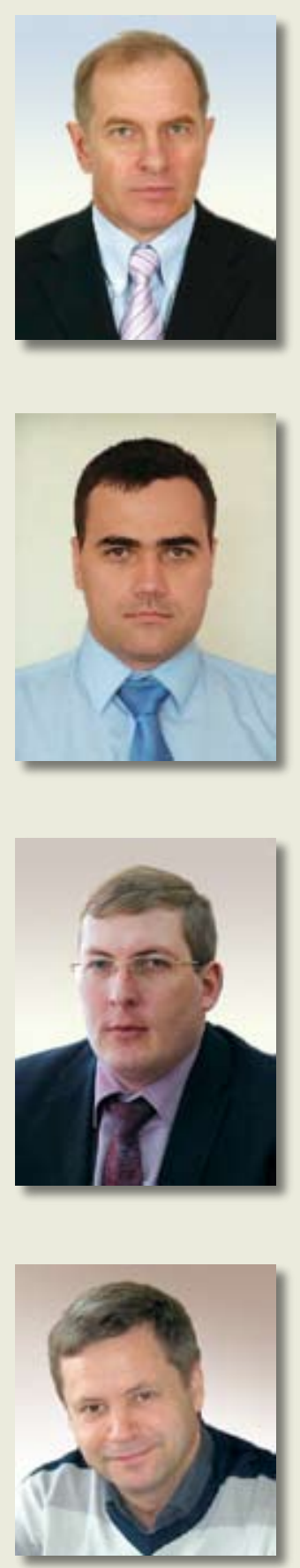

\section{БУЙНИЦКИЙ}

Александр Иванович

Первый заместитель исполнительного директора ЗАО «Разрез Березовский»

\section{КИлИн}

\section{Юрий Алексеевич}

Первый заместитель исполнительного директора ЗАО «Разрез Назаровский», канд. техн. наук

\section{попов}

Денис Владимирович Исполнительный директор ООО «Восточно-Бейский разрез»

\section{MAKAPOB}

Александр Михайлович Исполнительный директор ООО «НИИОГР», доктор техн. наук, npopeccop

\begin{abstract}
В статье сформулировано представление о функционале исполнительного директора угольного разреза, реализация которого позволяет повысить Уровень эффективности и безопасности производства.
\end{abstract}

Ключевые слова: функционал, директор, руководство, поток интересов, угольный разрез, рейтинг.

Контактная информачия: e-mail: makarovam_niiogr@mail.ru

Трудно не согласиться с одним из классиков менеджмента П. Друкером, который считает, что в деятельности руководителя текущая работа, как правило, поглощает все его время. Тем не менее она редко делается на должном уровне. Мало кто из руководителей полностью удовлетворен тем, как он решает задачи. Одни и те же проблемы возникают снова и снова, независимо от того, сколько раз их разрешали. Перспективы развития предприятия, требующие осмысления и проработки, отодвигаются на второй план. Но будущее не делается завтра, оно делается при решении задач сегодняшнего дня. Настоящее влияет на будущее, и, наоборот: то, что делается для будущего, прямо влияет на настоящее. Эти задачи пересекаются. Они требуют единой стратегии [1].

Для выработки такой стратегии от руководителя требуется, на наш взгляд, понимание предприятия как социально-экономической системы, которая предназначена и функционирует для удовлетворения интересов основных субъектов предприятия: государства, собственников (акционеров), менеджмента и рабочих. Исполнительный директор разреза как субъект управления отвечает перед акционерами, государственными и муниципальными органами управления за результаты деятельности предприятия, а перед рабочими - за обеспечение безопасных условий труда, оказывающих прямое влияние на достижение этих результатов. Исходя из этого, целевой функцией исполнительного директора угольного разреза является соединение труда и капитала, обеспечивающее требуемую динамику устойчивого развития предприятия с целью реализации социально-экономических интересов его субъектов.

Исполнительный директор имеет полномочия по предоставлению возможностей работникам угольного разреза для выполнения трудовых функций с заданными параметрами эффективности и безопасности, по определению гра- 
ниц ответственности и меры самостоятельности в принятии и реализации решений работниками. При этом он сохраняет за собой всю полноту ответственности. Исполнительный директор должен обладать навыками организации деятельности персонала по разработке программ развития, регламентов и стандартов, норм и нормативов, систем учета и контроля за деятельностью каждого работника.

В нашем понимании, исполнительный директор - это должностное лицо, руководитель, отвечающий за организацию оперативной деятельности предприятия, принимающий непосредственное участие в разработке и реализации стратегических, оперативных и тактических решений для достижения поставленной цели с приемлемым уровнем эффективности и безопасности.

Основным механизмом воздействия исполнительного директора является руководство. Под руководством нами понимается определение общих целей и задач, выбор алгоритма решения этих задач, организация взаимодействия персонала, осуществление контроля и ответственность за деятельность управляемой руководителем организации [2].

Основная формула руководства (по В.А. Галкину [3]):

$P=Ц+K+Y$, где: $P$ - руководство; $Ц-$ целеполагание; $K$ - конкордация; $Y$ - управление.

Целеполагание - процесс формирования общих целей, достижение которых удовлетворяет интересы ключевых субъектов угольного разреза, а также определение путей их достижения.

Конкордация - процесс формирования установок, интересов, умений и навыков личности, позволяющих ей осуществлять свою жизнедеятельность согласованно с деятельностью других членов общества [4].

Управление - целенаправленное волевое воздействие со стороны управляющего субъекта на работников и экономические объекты, осуществляемое для достижения общих целей и получения требуемых результатов.

Анализ и осмысление опыта деятельности, как собственного, так и других руководителей [5], позволили сформулировать принципы деятельности, основные задачи и методы работы исполнительного директора.

Основные принципы деятельности директора:

- директор всегда готов к любой ситуации;

- обеспечивая развитие предприятия, контролировать его текущую деятельность;

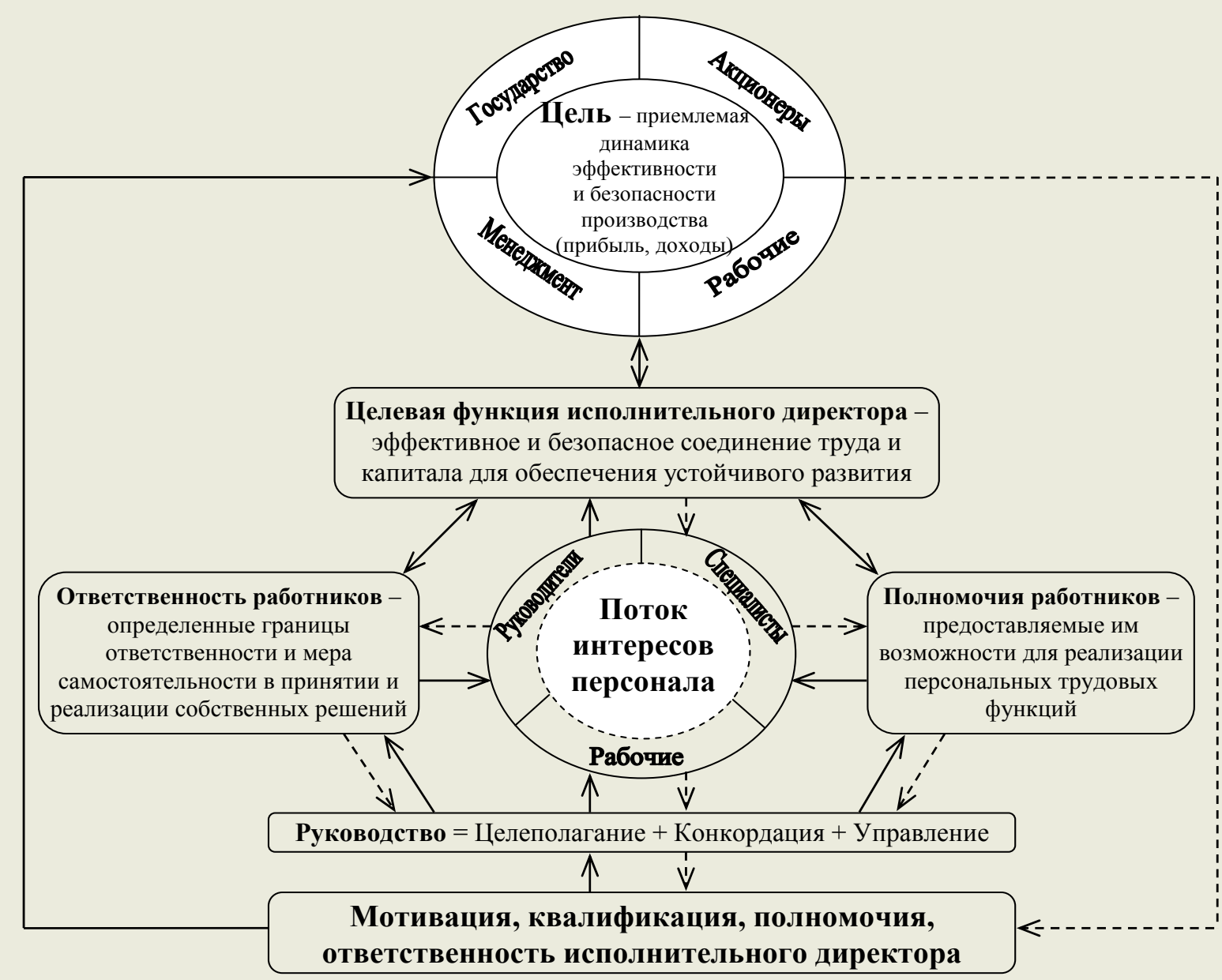

$\longrightarrow$ прямые связи

$---\rightarrow$ обратные связи

элементы функционала

Модель структуры функционала исполнительного директора 


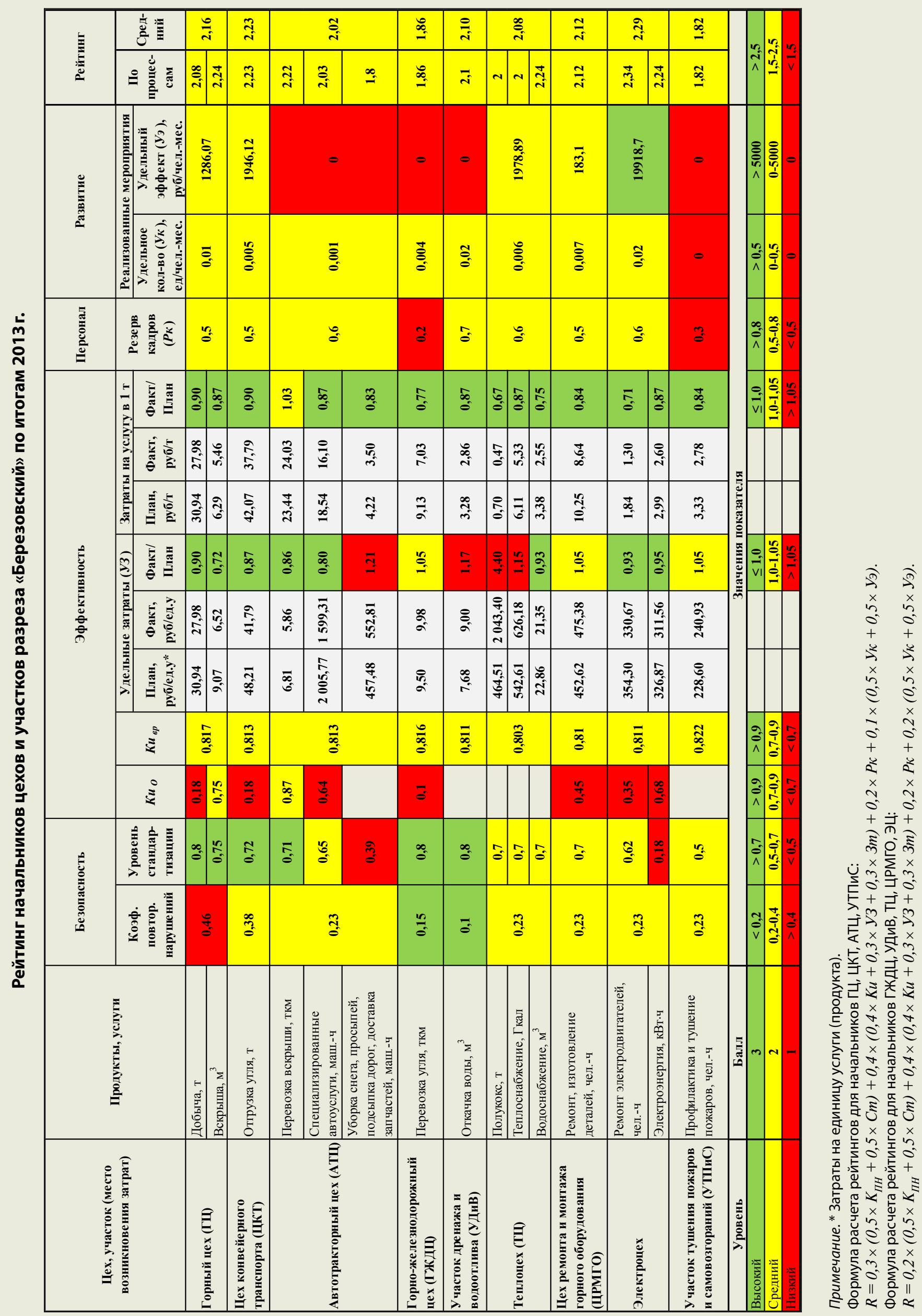


- нет нерешаемых задач. Возможности организации неисчерпаемы, нужно умело ими пользоваться;

- развивая каждого работника, развивать предприятие;

- не нужно все делать самому: необходимо распределить ответственность между работниками и наделить их необходимыми полномочиями, осуществляя при этом опережающий контроль [6];

- задача директора - выстроить требуемые отношения, наладить связи, создать резерв и уметь им эффективно пользоваться;

- размер поощрения соразмерен достижению, наказания - нарушению;

- достиг результата - делай следующий шаг.

Основная задача исполнительного директора - организовать систему взаимодействия и развития персонала, обеспечивающую приемлемую для ключевых субъектов предприятия динамику роста эффективности и безопасности производства, и контролировать ее функционирование и совершенствование.

Основной метод управления директора (по В.И. Кузнецову [7]) - регулирование потока интересов субъектов предприятия.

Для реализации перечисленных принципов, основных задачи и метода управления формируется функционал исполнительного директора - система функций и механизм их выполнения, обеспечивающие определенные параметры эффективности и безопасности деятельности и развития объекта управления. В формализованном виде структуру функционала исполнительного директора можно представить в виде модели (см. рисунок).

Механизмом достижения поставленных целей является руководство, направленное на управление потоком интересов персонала. Как показала практика, для формирования и управления потоком интересов руководителей, специалистов и рабочих следует организовать визуализированную систему учета и оценки результатов деятельности работников на каждом уровне управления, начиная от исполнительного директора и заканчивая рабочим. При этом в качестве ключевых оцениваемых направлений у руководителей всех уровней целесообразно использовать безопасность и эффективность производства, работу с персоналом и по развитию производства. Система учета и оценки результатов деятельности по этим направлениям позволит каждому руководителю определять и контролировать собственный рейтинг.

Рейтинг (R) руководителя можно рассчитывать как интегральный показатель по формуле:

$$
R=Б_{o y} \times k_{3 Б}+\vartheta_{o y} \times k_{3 \ni}+P \Pi \times k_{3 P \Pi}+P_{o y} \times k_{3 P \prime}
$$

где: $D_{o y}$ - интегральный показатель безопасности объекта управления, балл; Э эффективности объекта управления, балл; РП - интегральный показатель работы с персоналом, балл; $P_{o y}-$ интегральный показатель развития объекта управления, балл; $k_{3 b^{\prime}} k_{3 э}, k_{3 P I I}, k_{3 P}-$ коэффициенты значимости безопасности, эффективности, работы с персоналом и развития производства, соответственно. $k_{3 Б}+k_{3 \ni}+k_{3 Р \Pi}+$ $+k_{3 P}=1$.

Эти коэффициенты определяются в соответствии с приоритетами руководства компании, а также конкретного руководителя предприятия на данном этапе и назначаются экспертно. Значения каждого показателя соответствуют значениям балльной шкалы с выделенными уровнями: высокий - три балла, средний - два балла, низкий - один балл. Рейтинг рассчитывается как средневзвешенный балл, полученный в результате оценки деятельности по четырем направлениям.

Эта система проходит опробование на разрезах «Березовский», «Назаровский», «Восточно-Бейский» (см. табличу).

Таким образом, освоение функционала исполнительного директора, основанного на управлении потоком интересов руководителей, специалистов и рабочих угольного разреза, позволит сконцентрировать усилия персонала на достижении общих целей и развитии предприятия с приемлемой динамикой роста эффективности и безопасности производства.

\section{Список литературы}

1. Друкер П. Эффективное управление. - М.: 2003. 228 c.

2. Галкин В. А. Руководство - это что? Руководитель это кто? / В. А. Галкин, А. М. Макаров // Уголь: Специальный Выпуск, посвященный ОАО «СУЭК». - 2008. - С. 17-18.

3. Отчет НИИОГР о разработке функционалов руководителей ООО «Восточно-Бейский разрез» // Челябинск, 2014. - 25 c.

4. Артемьев В.Б. и др. Конкордация - критерий и средство повышения эффективности и безопасности производства / В. Б. Артемьев, А. Б. Килин, А. С. Костарев, В.П. Кавышкин, В. А. Галкин, А. М. Макаров // Уголь. 2014. — №3. — С. 68-72.

5. Onыm успешного руководства: Отдельная статья Горного информационно-аналитического бюллетеня / ЗАО «Распадская угольная компания», ООО «НИИОГР». М.: Изд-во «Горная книга», 2013. - 63 с. (Сер. «Б-ка горного инженера-руководителя». Вып. 22).

6. Артемьев B. Б. и др. Концепция опережающего контроля как средства существенного снижения травматизма / В. Б. Артемьев, А. Б. Килин, Г. Н. Шаповаленко, А. В. Ошаров, С.Н. Радионов, И.Л. Кравчук // Уголь. - 2013. № $5 .-$ С. 82-85.

7. Управление преобразованием производственного объединения по открытой угледобыче в эффективную компанию / Под ред. В. И. Кузнецова. - Челябинск: Рекпол, 1997. - 50 с. 


\section{Совершенствование системы}

\section{организационно-экономических отношений В 000 «Восточно-Бейский разрез»}

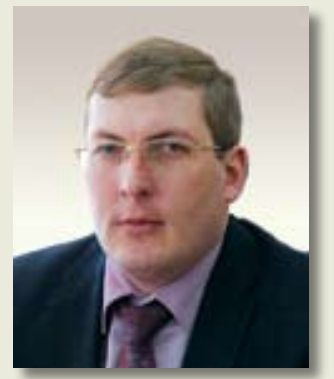

\section{попов}

Денис Владимирович

Исполнительный директор ООО «Восточно-Бейский

разрез»
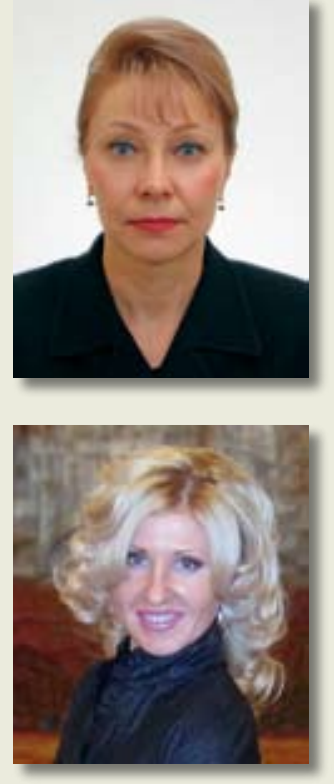

\section{АЛЕКСЕНКО}

Вероника Сергеевна

Главный экономист ООО «Восточно-Бейский разрез»

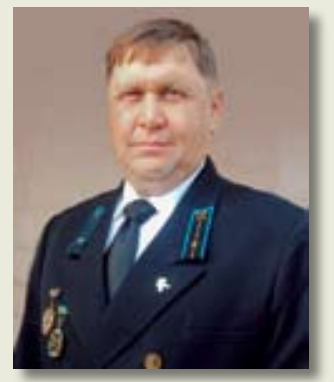

\section{МОРОЗОВ}

Александр Васильевич

Начальник участка добычи угля ООО «ВосточноБейский разрез»

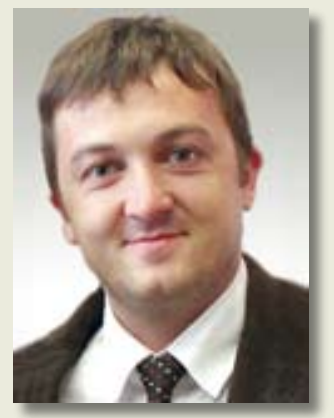

ЗАХАРОВ

Святослав Игоревич

Заведующий лабораторией «Организачия и оплата труда» ООО «НИИОГР», канд. экон. наук
В статье описаны основные направления совершенствования системы организационно-экономических отношений и опыт ее освоения в ООО «Восточно-Бейский разрез» для обеспечения непрерывного повышения эффективности производства.

Ключевые слова: организачионно-экономические отношения, эффективность, угольный разрез, организация производства.

Контактная информация: PopovDV@suek.ru

Современный этап обострения конкуренции на рынке угля обусловливает необходимость значимого повышения эффективности использования ресурсов производства для сохранения рыночных позиций предприятия. Сложившееся отношение персонала к ресурсам как к объекту чужой, «чьей-то» собственности приводит к тому, что решение этой задачи практически невозможно [1]. В этой связи совершенствование организационно-экономических отношений жизненно необходимо.

С 2007 г. в ООО «Восточно-Бейский разрез» формируется и осваивается система организационно-экономических отношений, в соответствии с которой каждое подразделение рассматривается как центр финансовой ответственности, а его руководитель, как распорядитель ресурсов, который планирует и контролирует эффективность их использования, организует реализацию мероприятий по улучшению производства в своей зоне ответственности. Характеризуя достигнутые результаты, следует отметить, что на предприятии стал правилом регулярный отчет руководителей производственных подразделений об использовании средств в соответствии с бюджетом затрат. Вместе с тем анализ удельных показателей эффективности [2] на примере участка добычи угля за январь-декабрь 2013 г. показал:

$\checkmark$ максимальная и минимальная эффективность использования различаются по оборудованию в 1,35 раза, по трудовым ресурсам - в 1,49 раза, по денежным средствам - в 1,61 раза;

$\checkmark$ средняя эффективность использования отличается от минимальной по оборудованию в 1,14 раза, по трудовым ресурсам - в 1,22 раза, по денежным средствам - в 1,31 раза (табл. 1).

Результаты анализа свидетельствуют о том, что руководитель подразделения является в значительной степени формальным распорядителем ресурсов, ориентированным на объемные показатели деятельности. Для того чтобы реально стать ответственным распорядителем ресурсов, необходимо проработать суть и содержание роли руководителя 
Показатели эффективности использования ресурсов участка добычи угля за период январь-декабрь 2013 г.

\begin{tabular}{|c|c|c|c|c|}
\hline \multirow{2}{*}{ Вид ресурса } & \multirow{2}{*}{ Формула расчета } & \multicolumn{3}{|c|}{ Фактические показатели, отн. ед.* } \\
\hline & & Минимум & Среднее & Максимум \\
\hline Оборудование & $\begin{array}{l}\text { Объем экскавации / вместимость } \\
\text { ковшей парка экскаваторов }\end{array}$ & 1,00 & 1,14 & 1,35 \\
\hline Труд & $\begin{array}{l}\text { Объем экскавации / трудозатра- } \\
\text { ты в наряде }\end{array}$ & 1,00 & 1,22 & 1,49 \\
\hline Денежные средства: & \multirow{7}{*}{$\begin{array}{l}\text { Затраты (по элементам себестои- } \\
\text { мости) / объем экскавации }\end{array}$} & 1,00 & 1,31 & 1,61 \\
\hline - на оплату труда & & 1,00 & 1,20 & 1,52 \\
\hline - на услуги по ремонту и эксплуатации оборудования & & 1,00 & 1,73 & 2,67 \\
\hline - на горюче-смазочные материалы & & 1,00 & 1,32 & 1,58 \\
\hline — на электроэнергию & & 1,00 & 1,39 & 1,98 \\
\hline - на услуги автоколонны технологического транспорта & & 1,00 & 1,28 & 1,90 \\
\hline - на услуги тракторно-бульдозерного участка & & 1,00 & 1,34 & 1,74 \\
\hline
\end{tabular}

в системе организационно-экономических отношений. Высшее руководство разреза осуществляло эту работу в ООО «НИИОГР» (г. Челябинск) в течение трех циклов (заездов). Первую группу возглавлял исполнительный директор разреза, вторую - главный инженер, третью - заместитель исполнительного директора по производству и автотранспорту.

В результате проделанной работы был выявлен значительный масштаб стоящих перед руководством задач и принято решение о необходимости совершенствования системы организационно-экономических отношений в ООО «Восточно-Бейский разрез». Для его реализации создана рабочая группа, в которую вошли начальники участков, служб, главные специалисты и руководители предприятия. Выбраны основные направления совершенствования организационно-экономических отношений, представленные на рисунке.

Рабочей группой были рассмотрены результаты ретроспективного анализа эффективности использования ресурсов в каждом подразделении, определены факторы и текущие возможности повышения эффективности, ресурсы, которые могут быть высвобождены из процесса производства и направлены на решение задач развития.

Для каждого производственного подразделения были определены целевые значения показателей эффективности. Использование целевых значений в качестве основных ориентиров деятельности позволило руководителям про- изводственных подразделений начать планировать эффективность использования ресурсов на следующий месяц. Для освоения этого подхода был разработан проект баланса производства (оказания) и потребления продукции (услуг) на месяц, в котором все участники взаимоотношений (10 руководителей подразделений) согласовали друг с другом объем оказываемых услуг и их стоимость (табл. 2).

Расчеты показали, что уже на этом, первоначальном этапе согласования объема и стоимости услуг возможная экономия ресурсов по предприятию составляет около 3,5\%.

Для налаживания системы ежесменного учета фактического количества оказанных услуг и их стоимости в ремонтно-механических мастерских, тракторно-бульдозерном участке, автоколонне №1, энергомеханической службе, энергоучастке были разработаны и начали применяться журналы учета отработанного времени и оказанных услуг.

Принято решение, что оперативный контроль за расходованием ресурсов на разрезе продолжает осуществлять финансово-экономическая служба во главе с заместителем исполнительного директора по финансам и экономике, а ход освоения новой системы взаимоотношений и промежуточные итоги работы подразделений ежедекадно будут рассматриваться на расширенном совещании рабочей группы под руководством исполнительного директора. Такая периодичность контроля позволит повысить оперативность принятия решений по достижению целевых показателей эффективности использования ресурсов.

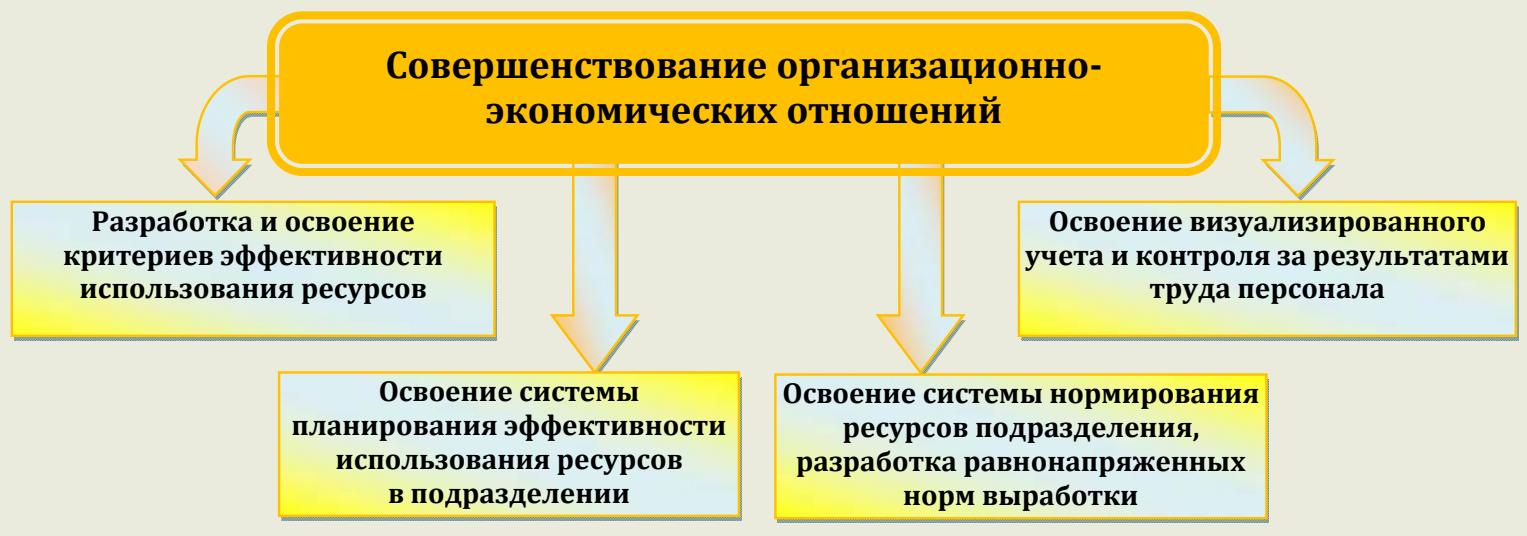

Направления совершенствования системы организационно-экономических отношений в ООО «Восточно-Бейский разрез» 
Форма баланса производства (оказания) и потребления продукции (услуг)

Таблича 2 в ООО «Восточно-Бейский разрез»

\begin{tabular}{|c|c|c|c|c|c|c|c|c|c|c|c|c|c|}
\hline \multicolumn{2}{|r|}{ ПОСТАВЩИК } & \multicolumn{12}{|c|}{ ПОТРЕБИТЕЛЬ } \\
\hline $\begin{array}{c}\text { Подразде- } \\
\text { ление }\end{array}$ & Продукция (услуга) & 斑 & $\begin{array}{l}\text { 듬 } \\
\text { 엋 }\end{array}$ & 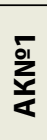 & 츰 & $\sum_{a}$ & $\begin{array}{l}\text { 은 } \\
\text { 눔 } \\
\text { 존 }\end{array}$ & $\begin{array}{l}\text { N } \\
\text { ol } \\
\text { 눈 }\end{array}$ & $\sum_{n}^{u}$ & $\sum_{0}^{U}$ & î & خે & 号 \\
\hline Уду & Тонна добытого угля & & & + & + & & + & + & & & & & + \\
\hline кусопП & Тонна отгруженной продукции & & & & + & & & & & & & & + \\
\hline AK№1 & Маш. -ч автосамосвала на линии & + & + & & & & & & & & & & \\
\hline ТБУ & Маш. -ч грейдера на линии & + & + & & & & & & & & & + & \\
\hline PMM & Чел. -ч & & & + & + & & + & + & & & & & \\
\hline Эу & Чел. -ч & + & + & + & & & & + & & & & & + \\
\hline AKN№2 & Маш. -ч вспомогательного транспорта & + & + & + & + & & & & & + & + & + & + \\
\hline ЭMC & Маш. -ч готовности экскаватора & + & & & & & & & & & & & \\
\hline
\end{tabular}

УДУ - участок добычи угля; КУСОПП - комплексный участок сортировки и отгрузки переработанной продукции; АК№1 - автоколон на №1 (технологическая); ТБУ - тракторно-бульдозерный участок; РММ - ремонтно-механические мастерские; ЭУ - энергоучасток; АК№2 - автоколонна №2 (вспомогательная); ЭМС - энергомеханическая служба; ОМТС - отдел материально-технического снабжения; БУХ - бухгалтерия; РСУ - ремонтно-строительный участок; ДИР - дирекция разреза (исполнительный директор).

«+»- стоимость поставляемой и приобретаемой продукции (услуг).

Таблица 3

Пример формы визуализированного учета производительного времени работы машинистов экскаваторов KOMATSU PC-1250 за период 1-4 марта 2014 г.

\begin{tabular}{|c|c|c|c|c|c|c|c|c|c|}
\hline \multirow{2}{*}{$\begin{array}{c}\text { ФИО машиниста } \\
\text { экскаватора КОМATSU } \\
\text { PС-1250 }\end{array}$} & \multirow{2}{*}{ Показатели } & \multicolumn{2}{|c|}{1 марта } & \multicolumn{2}{|c|}{2 марта } & \multicolumn{2}{|c|}{3 марта } & \multicolumn{2}{|c|}{4 марта } \\
\hline & & 1 смена & 2 смена & 1 смена & 2 смена & 1 смена & 2 смена & 1 смена & 2 смена \\
\hline \multirow{2}{*}{ C. C.B. } & Объем г/м, тыс. м³ & & 7016 & & & & & 6489 & \\
\hline & Произв. маш.-ч & & 9,7 & & & & & 9,0 & \\
\hline \multirow{2}{*}{ A. B. B. } & Объем г/м, тыс. м $^{3}$ & 7351 & & & 7127 & & & & \\
\hline & Произв. маш.-ч & 10,2 & & & 9,9 & & & & \\
\hline \multirow{2}{*}{ Ж. E. A. } & Объем г/м, тыс. м³ & & & & & 6910 & & & 7667 \\
\hline & Произв. маш.-ч & & & & & 9,6 & & & 10,6 \\
\hline \multirow{2}{*}{ П. Г.В. } & Объем r/m, тыс. м³ & & & 4162 & & & 7505 & & \\
\hline & Произв. маш.-ч & & & 5,8 & & & 10,4 & & \\
\hline \multirow{2}{*}{ Итого } & Объем г/м, тыс. м $^{3}$ & 7351 & 7016 & 4162 & 7127 & 6910 & 7505 & 6489 & 7667 \\
\hline & Произв. маш.-ч & 10,2 & 9,7 & 5,8 & 9,9 & 9,6 & 10,4 & 9,0 & 10,6 \\
\hline Цветовые обозначения: & более 9,3 ч; & $8,5-9,3$ & & менее & & & & & \\
\hline
\end{tabular}

Для уточнения размера резервов повышения эффективности деятельности подразделений на участках проведена оценка напряженности норм выработки на экскавацию и транспортирование горной массы. На основе результатов этой оценки нормы времени и выработки были пересчитаны с учетом необходимости обеспечения рациональных параметров ведения технологических процессов и равной напряженности труда исполнителей, тогда как ранее значения напряженности норм выработки различались до 1,5 раза. С использованием рассчитанных норм времени на участке добычи угля продолжено освоение системы ежесменного визуализированного учета производительного времени работы машинистов экскаваторов (табл. 3).

Освоение системы визуализированного учета результатов работы позволит сконцентрировать усилия персонала на достижении требуемых показателей эффективности подразделения и предприятия в целом [3].

Для повышения экономической ответственности и мотивации руководителей на следующем этапе развития организационно-экономических отношений в ООО «ВосточноБейский разрез» планируется ввести систему рейтингов начальников производственных подразделений.
Проделанная работа позволила приступить к формированию представлений линейных руководителей об организационных возможностях и способах повышения эффективности использования ресурсов в своей зоне ответственности. Оценка собственной деятельности в системе координат «время-деньги» способствовала осмыслению каждым руководителем позиции ответственного распорядителя ресурсов и выработке мер по улучшению своей системы деятельности.

\section{Список литературы}

1.Артемьев В.Б. и др. Конкордация - критерий и средство повышения эффективности и безопасности производства / В.Б. Артемьев, А.Б. Килин, А.С. Костарев, В.П. Кавышкин, В. А. Галкин, А. М. Макаров // Уголь. - 2014. №3. - С. 68-72.

2.В поискахновых возможностей развития предприятия/ Под общей ред. В.И. Усенко, А. М. Макарова. - ЛисаковскЧелябинск: 2002. - 164 с.

3. Рыбинский А. Б. и др. Об организации системы визуализированного учета результатов работы горнотранспортного участка ОАО «Разрез Тугнуйский» / А. Б. Рыбинский, А. В. Горохов, А.С. Довженок, С.И. Захаров, Ю. Ю. Ушаков // Уголь. - 2013. — №12. - С. 77-81. 


\section{УНИКАЛЬНАЯ ТЕХНОЛОГИЯ

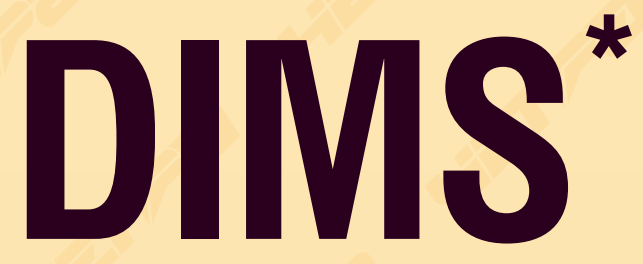

\section{для ЭКСкаваторов}

\section{Распределительная}

информационная

управляющая система DIMS позволяет:

Увеличить

скорость работы и производительность машины

\section{до $15 \%$}

Обеспечить экономию топлива до $10 \%$

Обеспечить оптимальное взаимодействие двигателя и гидравлической системы

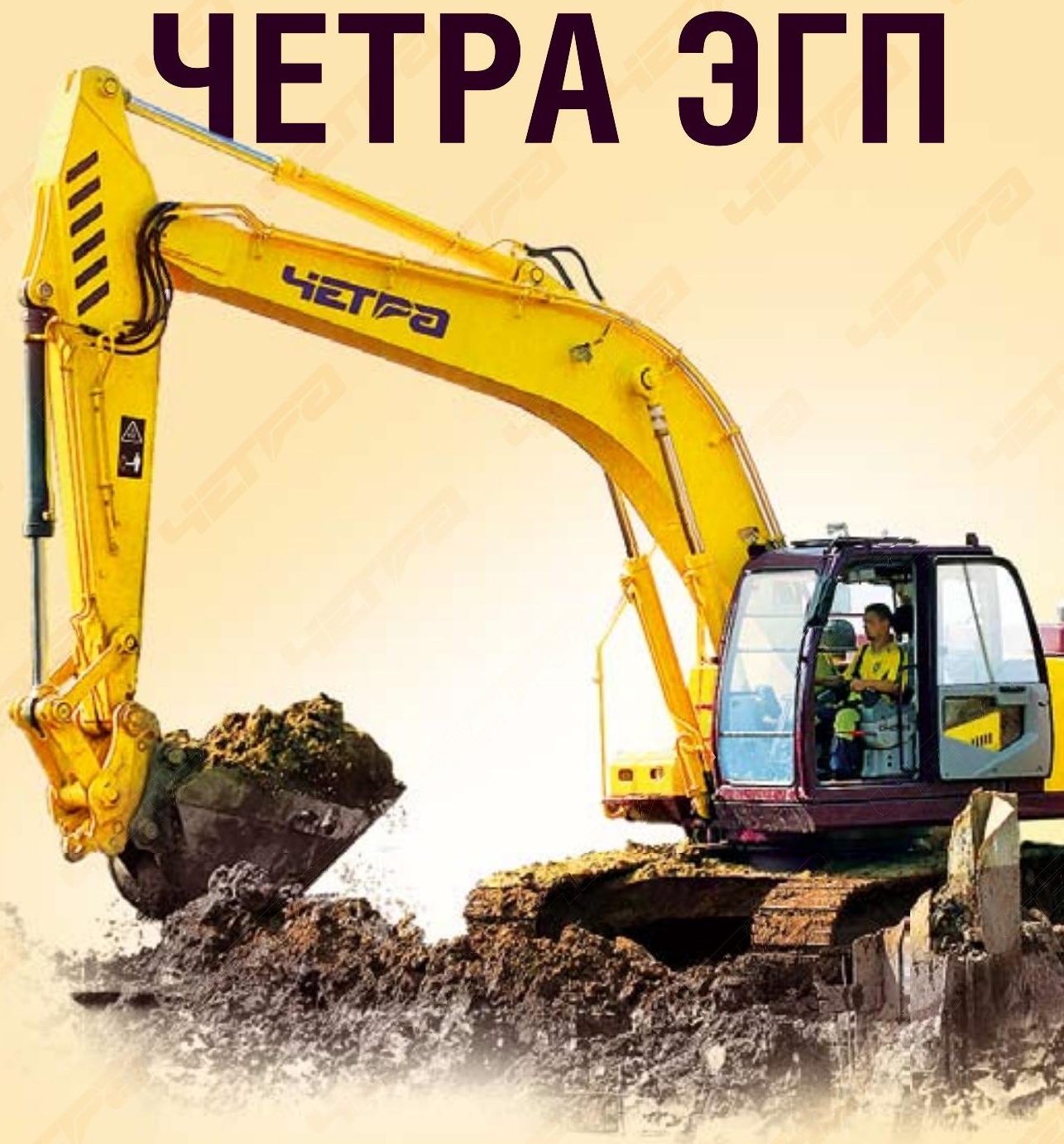

Обеспечить информирование оператора об основных параметрах работы экскаватора и возможных перегрузках

Передавать в режиме реального времени информацию о работе машины на завод-изготовитель (для более качественной технической поддержки)
Узнать больше 


\section{Некоторые аспекты взрыва относительно теории поглощения энергии*}

В статье представлены возможности в плане флегматизации взрыва на основе применения вакуума, локализации кислорода, эндотермической реакции в шахтах, опасных по газу и пыли, внезапных выбросов пород; искусственного получения метана в природных условиях на основе теории поглощения энергии.

Ключевые слова:уголь, взрыв, метан, поглощение взрыва, экзотермическая и эндотермическая реакции, безопасность.

Контактная информация:

e-mail:volinad@mail.ru

Происходящие в шахтных условиях взрывы метано-воздушной смеси (МBC) сопровождаются жертвами и разрушениями, распространением пожаров. Вопросы предупреждения и противодействия взрывам MBC весьма актуальны.

Наиболее экологически чистым производным природы является газ, который выражается простой формулой $\mathrm{CH}_{4}$ являющейся неистощимой формулой энергии.

Почему нельзя предположить, что газовые скважины, дебетирующие, как правило, до 30 \% содержимого, не могут восполняться закачкой водородосодержащего продукта. На практике это подтверждает рождение болотного газа с условиями брожения продуктов биораспада.

В реальных условиях реакция шахтного метана с кислородом воздуха, как известно, сопровождается выделением большого количества тепла. Реакция оксида кальция (CaO) с водой тоже сопровождается выделением большого количества тепла. О чем могут говорить эти факты? При образовании новых химических связей в продуктах реакции выделяется больше энергии, чем требуется на разрыв химических связей в реагентах. Избыток энергии выделяется в виде тепла, света и воздушных колебаний.

$\mathrm{CH}_{4}+2 \mathrm{O}_{2}=\mathrm{CO}_{2}+2 \mathrm{H}_{2} \mathrm{O}+$ энергия (свет, тепло, воздушные колебания);

$\mathrm{CaO}+\mathrm{H}_{2} \mathrm{O}=\mathrm{Ca}(\mathrm{OH})_{2}+$ энергия (тепло, воздушные колебания).

Реакции, в которых энергия выделяется, принято называть экзотермическими.

Другое дело - обратные реакции. Получить метан из $\mathrm{CO}_{2}$ и воды до сих пор не удается, а для получения негашеной извести $\mathrm{CaO}$ из гидроксида кальция $\mathrm{Ca}(\mathrm{OH}){ }_{2}$ требуется сильное нагревание. Такая реакция идет только при постоянном притоке энергии извне:

\footnotetext{
* В порядке обсуждения - Ред.
}

$\mathrm{Ca}(\mathrm{OH})_{2}+$ энергия (тепло) $=\mathrm{CaO}+\mathrm{H}_{2} \mathrm{O}$. Это говорит о том, что разрыв химических связей в Са $(\mathrm{OH})_{2}$ требует большей энергии, чем может выделиться при образовании новых химических связей в молекулах $\mathrm{CaO}$ и $\mathrm{H}_{2} \mathrm{O}$. Реакции, в которых энергия поглощается, называются эндотермическими.

На основе соединения, экзотермической и эндотермической реакций происходит гашение разрушительных действий взрыва, пожара, тления.

Основываясь на теории погашения энергии, которая соответствует и продолжает Теорию относительности, к которой раннее пришел А. Пуанкаре (горный инженер), А. Эйнштейну удалось показать, что такие разные физические параметры, как материя и энергия, являются проявлениями единой материи - энергии. Он упорно работал над созданием единой теории поля, но окончательно этого не удалось сделать до сих пор.

Как утверждает теория, зависимость энергии тела от скорости рассматривается как:

$$
E=\frac{m c^{2}}{\sqrt{1-v^{2} / c^{2}}} .
$$

В системе отсчета, связанной с телом, его скорость равна нулю, а энергия, которую называют энергией покоя, выражается формулой:

$$
E_{0}=m c^{2} \text {. }
$$

Это минимальная энергия, которую может иметь массивное тело. Значение формулы А. Эйнштейна также в том, что до нее энергия определялась с точностью до произвольной постоянной, а формула А. Эйнштейна находит абсолютное значение этой постоянной.

Если физическая система является замкнутой, то ее энергия сохраняется в этой системе на протяжении времени, в течение которого система будет являться замкнутой:

$$
E_{0}-m c^{2}=0 \text {. }
$$

Энергия как физическая величина целесообразна только в том случае, если рассматриваемая физическая система однородна во времени. Подтверждением процессов поглощения энергии является теория вакуума, высказанная В. Дятловым, теория торсионных полей Г. Шипова.

Таким образом, возникают предпосылки создания противовзрывного устройства, которое может поглотить взрыв метана и угольной пыли, а также противооружия, способного поглотить взрыв. Происхождение материи Вселенной объясняется результатом поглощения Большого взрыва. 


\section{Бригада Олега Кукушкина шахты «Имени А.Д. Рубана» ОАО «СУЭК-Кузбасс» добыла}

\section{миллион тонн угля с начала года}

20 марта 2014 г. бригада Олега Кукушкина участка №1 шахты «Имени А. Д. Рубана» ОАО «СУЭК-Кузбасс» добыла миллионную тонну угля с начала года.

Этот очистной коллектив стал первым «миллионером» в 2014 г. в Сибирской угольной энергетической компании.

Бригада Олега Кукушкина отрабатывает лаву №804 пласта «Полысаевский 2» с вынимаемой мощностью 4,9 м. Забой оснащен прошедшими модернизацию 130 секциями механизированной крепи DBT-2250/5500 (Германия). В комплект забоя входит также высокопроизводительный очистной комбайн ELECTRA-3000, лавный конвейер PF-4/1032, перегружатель ST PF-4/1132, дробилка ударная валковая SK-11/11. Все оборудование комплекса - производства Deutsche Bergbau Technik (DBT).

Поздравляя коллектив с очередной трудовой победой, генеральный директор ОАО «СУЭК-Кузбасс» Евгений Ютяев отметил, прежде всего, стабильную работу шахты на протяжении долгого времени, умение устойчиво сохранять высокие нагрузки на забои. Это является признаком настоящего шахтерского мастерства.

Напомним, что за два года бригада Олега Кукушкина пять раз обновляла рекорды шахты по месячной добыче. Лучший результат - 530 тыс. т. В целом, за 2013 г. слаженный коллектив очистников выдал на-гора 2,9 млн т угля.

\section{ОАО «Мурманский} морской торговый порт» признано лучшей стивидорной компанией

21 марта 2014 г. в г. Санкт-Петербурге прошла 27-я Конференция Ассоциации морских торговых портов России, на которой были подведены итоги Конкурса «Лучшая стивидорная компания Ассоциации морских торговых портов» за 2013 год. Победителем конкурса признано ОАО «Мурманский морской торговый порт» (ОАО «ММТП»).

Ежегодный конкурс «Лучшая стивидорная компания Ассоциации морских торговых портов» призван определять российские стивидорные компании, которые добиваются наилучших показателей эффективности своей работы и делать их опыт достоянием других стивидорных компаний портов России.

Ассоциация морских торговых портов объединяет более 50 отраслевых организаций и предприятий морского транспорта России. Основной задачей Ассоциации является координация усилий профессионального сообщества по созданию условий для эффективного развития предприятий морского транспорта и реализации транспортного потенциала России.

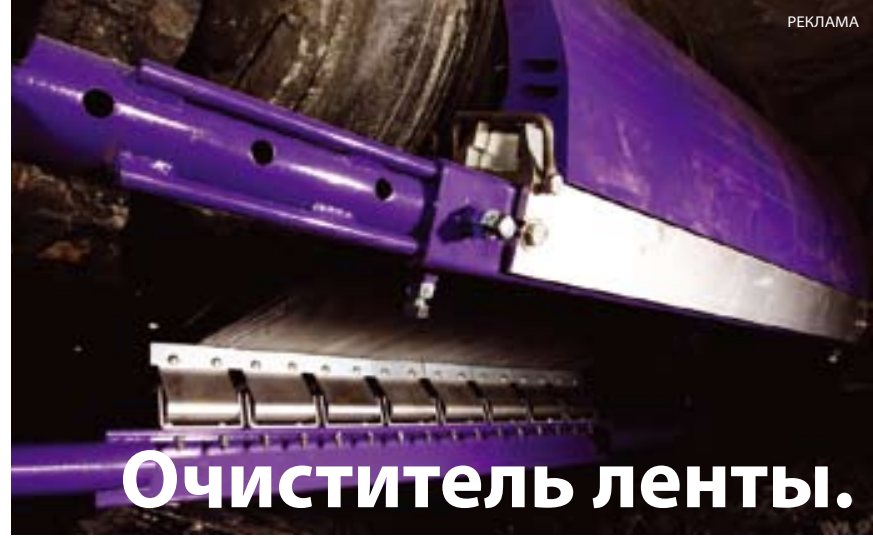

Система крепления $\mathrm{SR}^{\mathrm{m}}$

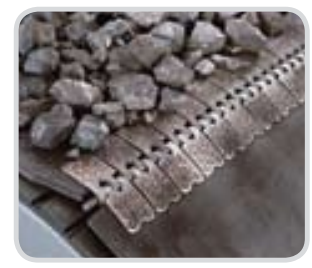

FLEXCO EUROPE GmbH Leidringer Straße 40 - 42 D-72348 Rosenfeld Тел.: +49-7428-9406-0 Факс: +49-7428-9406-260 E-Mail: europe@flexco.com
Система для очистки лент

Проверенная на практике, простая в установке система для первичной и вторичной очистки ленты, сочетающая отличные эксплуатационные качества с идеальной совместимостью с системой креплений.

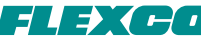

www.flexco.com 


\section{Двухступенчатая гидроэлеваторная установка для откачки и очистки глубоких зумпфов}

\author{
АНТОНОВ Эдуард Иванович \\ Заведующий отделом шахтного водоотлива \\ ПАО «Научно-исследовательский институт \\ горной механики им. М.М. Федорова», \\ доктор техн. наук
}

\section{ГРЯДУЩИЙ Кирилл Владимирович}

Научный сотрудник отдела шахтного водоотлива ПАО «Научно-исследовательский институт горной механики им. М.М. Федорова»

В статье представлены результаты разработки и экспериментально-производственных исследований характеристик и рабочих параметров высоконапорных зумпфовых гидроэлеваторных установок. Доказано, что двухступенчатые установки, снабженные предвключенной низконапорной ступенью, по целому ряду технико-экономических показателей (по эксплуатационному КПД, величине относительного напора, всасывающей способности) заметно превосходят традиционно применяемые одноступенчатые схемы, что создает реальные предпосылки для резкого повышения эффективности и безопасности работы стационарного зумпфового водоотлива при одновременном обеспечении безлюдной откачки и очистки от просыпи зумпфов практически любой глубины.

Ключевые слова: зумпфовый водоотлив, высоконапорная насосно-гидроэлеваторная установка, очистка и откачка зумпфов.

Контактная информация: e-mail:

naukoviy_centr_niigm@inbox.ru;

naukoviy_centr_niigm@inbox.ru

Анализ многолетнего опыта откачки водопритоков и очистки зумпфов скиповых стволов от просыпи свидетельствует о том, что условия выполнения данных вспомогательных операций остаются крайне тяжелыми. Обслуживающий персонал выполняет указанные работы в тяжелых, антисанитарных и небезопасных, условиях [1]. При этом, как показала практика эксплуатации глубоких зумпфов в последние годы (например, на шахтах им. А.Г. Стаханова ГП «Красноармейскуголь» и им. Л.И. Лутугина ГП «Торезантрацит»), имеют место опасные для жизни людей прорывы значительных объемов водоугольных гидросмесей из угольных ям в нижнюю часть зумпфов скиповых стволов. Все это обусловливает необходимость пересмотра существующей технологии очистки и откачки зумпфов, что в наибольшей степени касается зумпфов повышенной глубины - более 50-70 м.

В результате выполненных в НИИГМ им. М.М. Федорова исследований установлено, что указанные недостатки уст- раняются с использованием двухступенчатых схем гидроэлеваторных установок с использованием низконапорной предвключенной (бустерной) ступени [2-4].

Схема двухступенчатого гидроэлеватора, или водоструйного аппарата, представлена на рис. 1.

В процессе работы установки рабочий поток поступает в сопла аппаратов 4 и 5. Всасываемая при этом гидросмесь на входе в нижнюю, предвключенную, ступень аппарата 4 приобретает запас энергии, позволяющий транспортировать ее к верхней высоконапорной ступени 5 и далее - к месту сбора, например в специальный шламонакопитель. Транспортирование гидросмеси осуществляется по пульповоду 8, подключенному к выходу из ступени 5. Установка снабжена задвижками 13 и 14, первая из которых установлена на трубопроводе 3 рабочей воды - для возможности введения установки в работу, а вторая - на трубопроводе (пульпопровод) 8.

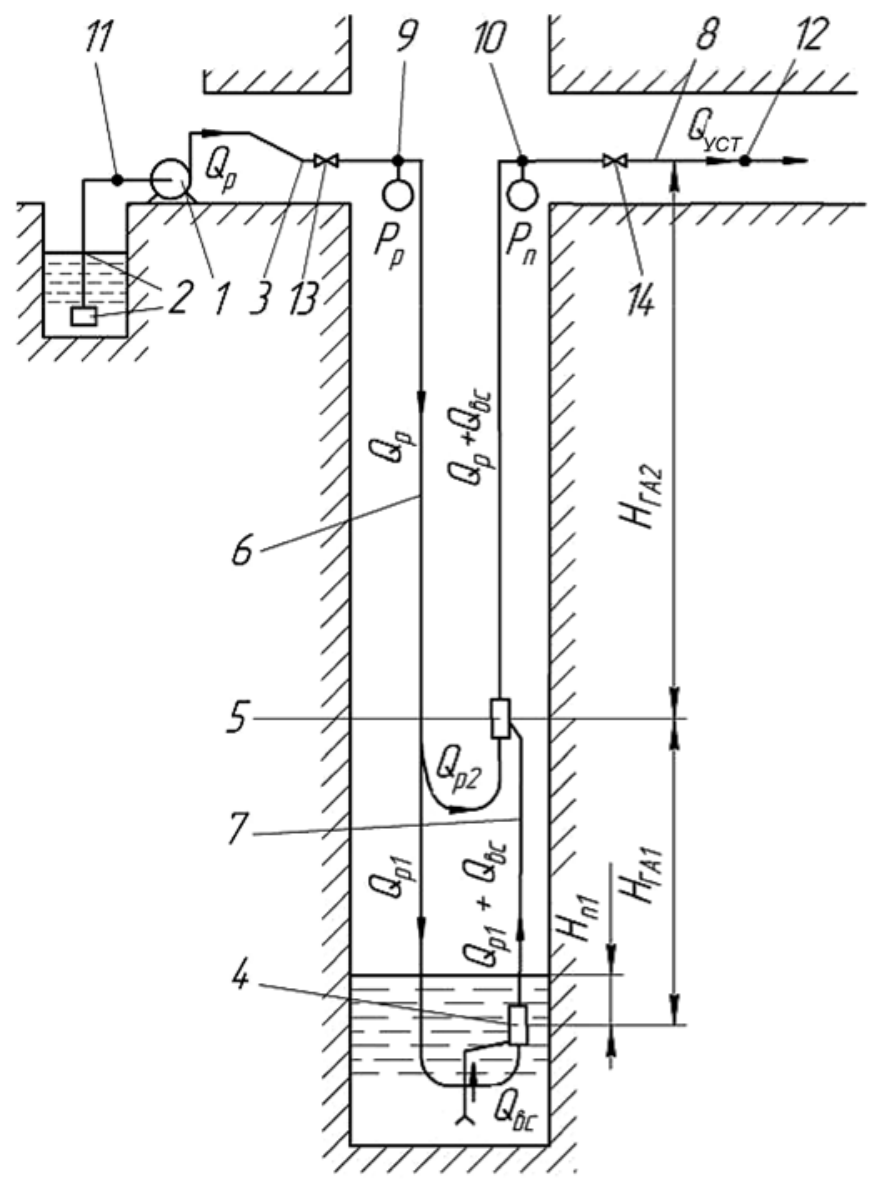

Puc. 1. Схема зумпфового двухступенчатого аппарата: 1 - рабочий насос; 2 - всасывающий трубопровод; 3- напорный трубопровод; 4 - нижняя ступень; 5 - верхняя ступень; 6 - рабочий трубопровод; 7 - соединительный трубопровод; 8- пульповод; 13, 14-задвижки 
Рассмотрим кратко основные результаты работы по созданию, теоретическому и экспериментальному исследованию параметров, эксплуатации двухступенчатых зумпфовых гидроэлеваторных установок, предназначенных для условий откачки и очистки зумпфа действующего скипового ствола «Пугачевка» гор. 1146 м шахты им. Ф.Э. Дзержинского ГП «Дзержинскуголь».

К основным исходным данным расчета аппаратов были отнесены следующие параметры:

- геометрическая высота водоподъема твердого $H_{\Gamma A}=H_{\Gamma A 1}+H_{\Gamma A 2}=110 \mathrm{~m}$;

- длина горизонтального участка пульповода 8 290 м;

- подача установки $-Q_{B C}=70 \mathrm{~m}^{3} / 4$;

- тип рабочего насоса - ЦНС 300-300.

Анализ возможных вариантов гидравлических и геометрических параметров установок был выполнен на основе использования разработанного в НИИГМ аналитического метода расчета режимов работы [2] зумпфовых насосногидроэлеваторных установок и расходно-кавитационной характеристики [3] аппаратов (обобщающей результаты известных исследований и методы расчета аппаратов для условий работы на зумпфовом водоотливе). Выбор размещения ступеней двухступенчатого аппарата в пределах зумпфа по высоте был осуществлен сучетом технологических особенностей последнего ( $\left.H_{\Gamma A 1}=38 \mathrm{~m} ; H_{\text {IA2 }}=72 \mathrm{~m}\right)$.

В процессе анализа полученных расчетных характеристик и параметров ряда возможных вариантов установок было установлено, что применение двухступенчатого аппарата обеспечивает возможность повышения эксплуатационного КПД - $\eta_{\text {уст, }}$ по сравнению с традиционно применяемой одноступенчатой его схемой, в 1,5-2,5 раза при одновременном снижении требуемого напора $H_{P}$ рабочей жидкости не менее чем 1,5 раза.

На основе результатов выполненных расчетов был разработан рабочий проект на зумпфовую установку, включающий два двухступенчатых аппарата - рабочий и резервный. Последние были изготовлены, смонтированы и введены в эксплуатацию в сентябре 2007 г. После ввода в эксплуатацию были выполнены инструментальные измерения параметров режимов работы насосно-гидроэлеваторных установок в целом. При этом измерение давления $P_{P}$ рабочего потока осуществлялось в точке 9 (см. рис. 1) - перед вертикальным участком рабочего трубопровода 6, а давление $P_{\Pi}$ - за вертикальным участком пульповода 8 - в точке 10 . Суммарный расход воды $Q_{\text {уст }}$ определялся за аппаратом в точке 12 - на горизонтальном участке пульповода 8. Подача рабочей воды $Q_{P}$ измерялась на горизонтальном участке всасывающего трубопровода рабочего насоса 1 - в точке 11. Для измерения расхода воды использовался разработанный в НИИГМ измеритель скорости потока «ИСКРА-2» (погрешность измерения не превышает $3 \%$ ), а определение давления осуществлялось с помощью образцовых манометров класса точности 0,4\%. Подача аппарата $-Q_{B C}=Q_{y_{C T}}-Q_{P}$. Величина КПД двухступенчатого аппарата рассчитывалась по формуле:

$$
\eta_{2 C T}=\frac{Q_{B C}}{Q_{P}} \cdot \frac{H_{\Gamma A}+\Delta H_{\Pi \Gamma}+\Delta H_{\Pi P}}{H_{P}},
$$

где: $\Delta H_{\Pi Г}, \Delta H_{\Pi Р}-$ потери напора, соответственно в горизонтальном и вертикальном участках пульповода 8 за верхней ступенью 5 аппарата; $H_{P}$ - напор рабочего потока - в точке 9, $H_{\Gamma A}=H_{\Gamma A 1}+H_{\Gamma A 2}$ - геометрическая высота нагнетания аппарата (см. рис. 1).

Как следует из вышеизложенного, все параметры, входящие в зависимость (1), были определены на основе экспериментальных данных.

На рис. 2 представлены: расчетные напорные характеристики, 1 и 2, нижней и верхней ступеней рабочего аппарата; характеристики их напорных трубопроводов, 3 и 4; приведенная напорная характеристика 5 второй (верхней) ступени аппарата, отражающая влияние статического подпора на ее всасе, создаваемого с помощью нижней ступени; экспериментально установленная напорная характеристика аппарата 6 и фактический режим его работы (точка 7) $-Q_{\text {уст }}=248,5 \mathrm{~m}^{3} / 4$.

На основе полученных результатов исследований установлено, что значения относительных отклонений расчетных величин основных параметров установки (подачи $Q_{B C}$ и $\eta_{y C T}$ ) от экспериментальных $Q_{B C}=69,3 \mathrm{~m}^{3} / 4 ; \eta_{y C T}=0,205$ не превышает $8 \%$. В целом сравнение результатов теоретических и экспериментальных (производственных) данных позволило подтвердить теоретически установленную возможность повышения эксплуатационного $\eta_{\text {уст }}$ двухступенчатого зумпфового аппарата не менее чем в два раза по сравнению с одноступенчатой его схемой при одновременном снижении требуемого напора $H_{P}$ не менее чем 1,5 раза.

В процессе многолетней эксплуатации разработанных установок средняя суточная их наработка составляла 20 ч. Нижние ступени поочередно включаемых рабочей и резервной установок значительную часть времени эксплуатации функционировали в условиях развитых завалов, высота которых достигала 2-2,5 м и более (по отношению к отметке установки срезов сопел нижних ступеней аппаратов). Максимальная высота всасывания нижних ступеней аппаратов в отдельные периоды достигала 6,5-7 м. По данным шахты, за первые два с половиной года эксплуатации насосно-гидроэлеваторной установкой была выдана масса твердого в объеме более 1800-2000 м³. Средняя объемная концентрация твердого в откачиваемой гидросмеси - 0,05-0,1, а в моменты их работы под завалами - 0,2-0,25.

Дальнейшим развитием работ в рассматриваемом плане явилось создание насосно-гидроэлеваторной установки для очистки и откачки зумпфа скипового ствола гор. 995 м шахты «Октябрьский рудник» ГП «ДУЭК». В данном случае максимальная высота нагнетания составила 85 м, что на 26 м меньше, чем в случае откачки зумпфа скипового ствола на шахте им. Ф.Э. Дзержинского. Одновременно длина (двух) горизонтальных ветвей пульповода оказалась в 1,28-1,6 раза большей. Кроме того, при проектировании определенную сложность вносил тот факт, что внутренний диаметр вертикального участка пульповода не мог быть принят более 150 мм - из-за значительного загромождения оборудованием поперечного сечения зумпфа. Вследствие этого экспериментально установленная величина $\eta_{y_{C T}} \approx 0,17$ оказалась заметно более низкой. Но даже в этом случае она превысила более чем в 1,5 раза экспериментальные значения КПД высоконапорных зумпфовых одноступенчатых аппаратов, не превосходящих уровня $\eta_{y C T}=0,11$. 


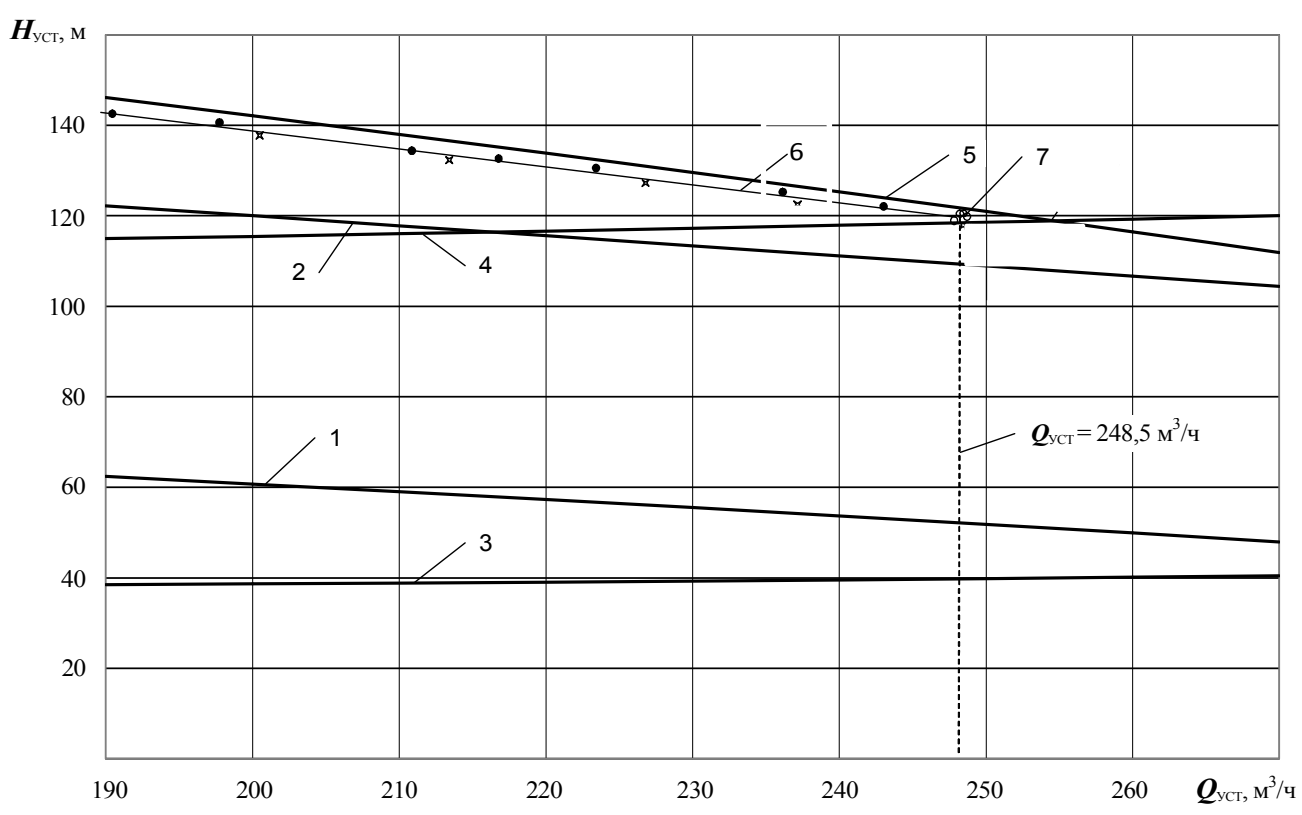

Рис. 2. Расчетный и фактический режимы работы высоконапорного двухступенчатого зумпфового annapama
Рассмотренные выше насосно-гидроэлеваторные установки к настоящему времени находятся в эксплуатации более пяти лет. Благодаря их использованию на обеих шахтах удалось решить важные практические задачи по обеспечению требуемых условий эксплуатации скиповых подъемов. Это, в свою очередь, дало возможность интенсификации работ по добыче угля на соответствующих горизонтах шахт. В соответствии с данными специалистов шахты «Октябрьский рудник» экономический эффект от внедрения установки составляет не менее 1 млн грн. вгод.

В итоге, обобщая все вышеизложенное, можно вполне обоснованно считать, что выполненный комплекс работ создает реальные предпосылки для резкого повышения эффективности и уровня безопасности стационарного зумпфового водоотлива при одновременном обеспечении безлюдной или близкой к ней откачки и очистки зумпфов практически любой глубины.

\section{Список литературы}

1. Безуглов И. Н., Безуглова Л. И., Горчаков А. Я. Гидроэлеваторы на угольных шахтах. - М: Недра, 1986. - 114 с.

2. Антонов Э. И., Грядущий К. В. Расчет режимов работы зумпфовой насосно-гидроэлеваторной установки с двухступенчатым водоструйным аппаратом // Проблеми експлуатації обладнання шахтних стаціонарних установок: Сб. науч. тр. НИИГМ им. М. М. Федорова. - Вып. 1062107. - Донецк, 2012-2013. - С. 159-166.

3. Антонов Э.И., Грядущий К.В. Влияние высоты всасывания зумпфовых водоструйных аппаратов на их рабочие параметры // Проблеми експлуатації обладнання шахтних стаціонарних установок: Сб. науч. тр. НИИГМ им. М.М. Федорова. - Вып. 102-103. - Донецк, 2008-2009. - С. 134-148.

4. Патент на корисну модель №38361. Україна, МПК F04D13100. Шахтна зумпфова двоступінчаста гідроелеваторна установка / Е.І. Антонов, Б.А. Грядущий, К.В. Грядущий; U200811638. Заявлено 29.09.2008. - Опубл. 12.01.2009. — Бюл. №1.

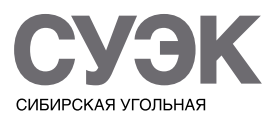
ЭНЕРГЕТИЧЕСКАЯ КОМПАНИЯ

\section{Бригада Владимира Мельника шахты «Котинская»} ОАО «СУЭК-Кузбасс» добыла миллион тонн угля с начала года

31 марта 2014 г. бригада Героя труда России Владимира Мельника участка №1 шахты «Котинская» ОАО «СУЭК-Кузбасс» добыла миллионную тонну угля с начала года.

Этот очистной коллектив стал вторым «миллионером» в 2014 г. в Сибирской угольной энергетической компании вслед за бригадой Олега Кукушкина шахты «Имени А.Д. Рубана».

Бригада Владимира Мельника отрабатывает лаву №52-09 с вынимаемой мощностью пласта 4,2 м. Забой оснащен 159 секциями механизированной крепи DBT-220/480. B комплекс входит также высокопроизводительный очистной комбайн SL-500, лавный конвейер PF-4/1032. Все оборудование комплекса производства Германии.

Коллектив с очередной трудовой победой поздравил генеральный директор ОАО «СУЭК-Кузбасс» Евгений Ютяев. Он поблагодарил горняков за умелое использование эффективных технологий, высокий уровень профессионализма.

Напомним, что бригада под руководством бригадира Владимира Мельника единственная в России, четыре раза добывавшая из одного очистного забоя четыре и более миллиона тонн угля. 


\section{Основные направления внедрения базальтовых} композитных материалов в горную промышленность

\begin{abstract}
В статье рассмотрены опыт и возможности применения базальтакомпозитных материалов в горном машиностроении, при производстве конвейерных лент, анкеров, защитных сеток, скребковых конвейеров, ставов ленточных конвейеров, гидроцилиндров и огнестойких защитных панелей.

Ключевые слова: композит, базальт, конвейерная лента, став конвейера, ролик, базальтакомпозитный шнур, скребковый конвейер, анкер, сетка, панель, профиль.

Контактная информация:

e-mail: transbelt@mail.ru
\end{abstract}

В соответствии с поручением Президента России от 20декабря 2012 №2433-р г. Правительство Российской Федерации разработало долгосрочную программу по разработке и внедрению в отечественную промышленность композитных материалов.

Композитные материалы на основе базальтового ровинга и базальтового пластика все больше находят применение в различных отраслях промышленности. За рубежом изделия из базальта широко применяются в автомобильной, строительной, судостроительной, авиационной, нефтяной и других промышленностях.

В горной промышленности внедрение композитных материалов на основе базальта весьма низкое из-за недостаточного финансирования НИОКР Минобрнауки России и должного внимания со стороны бизнеса.

ООО «Торговый дом «Трансбелт» совместно с ООО «Рекстром М» разработаны ряд конструкций и изделий с применением базальтовых композитных материалов применительно к горной промышленности.

Базальта-пластиковые профили для изготовления ставов ленточных конвейеров. Основное их преимущество - это низкий вес (в пять раз легче), полное отсутствие коррозии, высокая прочность при минусовых температурах эксплуатации $\left(-50{ }^{\circ} \mathrm{C}\right)$, возможность быстрого монтажа и демонтажа в любых условиях

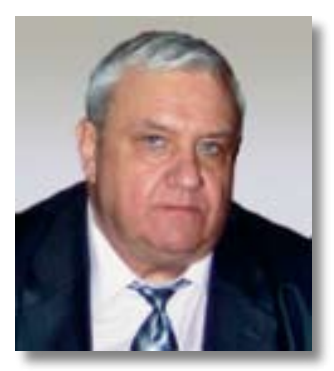

СОЛОВЬЕВ

Валентин Георгиевич Директор 000

«Торговый дом «Трансбелт», канд. техн. наук

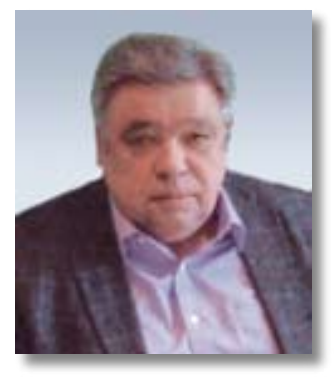

МАРЬИН

Владимир Васильевич Генеральный директор ООО «Рекстром М»

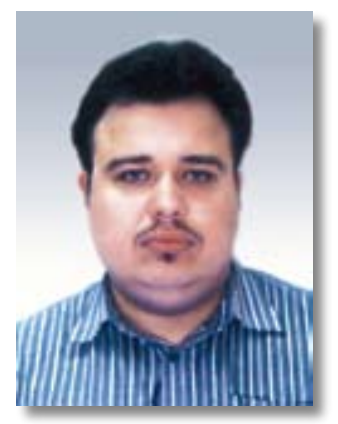

СОЛОВЬЕВ

Сергей Валентинович

Горный инженер, аспирант кафедры ГМО МГГУ (особенно в шахтных условиях и карьерах) без применения грузоподъемных механизмов. Данные конвейера позволят более широко применять поточный транспорт при добыче полезных ископаемых открытым способом в условиях Крайнего Севера и Дальнего Востока

Анкерные крепи, изготовленные из базальтового композитного материала, превосходят металлические анкерные крепи и крепи из стеклокомпозита по прочностным характеристикам до 50 т для кровли и до 20 т для бортов горных выработок. Они не подвержены коррозии и химическому воздействию. ООО «Рекстром М» разработал технологию крепления анкеров в любой породе. Это позволяет устанавливать защитную базальтовую сетку или ткань для крепления пород любой сыпучести.

Нами разработана базальтовая композитная нить (шнур) с усилием на разрыв 1000 Н/мм. и более. Данные шнуры позволят изготавливать безопасную защитную шахтную сетку с усилием на разрыв 60 т/м² и более. В комплексе с анкерными крепями, из базальта композитных материалов, выдерживающими усилие на разрыв до 50 т, данные сетки позволяют изготавливать защитные устройства для крепления горных выработок для горнопроходческих работ и шахт.

Данная базальтакомпозитная нить позволяет изготовить несущую ткань для конвейерных лент с усилием на разрыв 10000 Н/мм и более, что позволит полностью отказаться от многопрокладочных конвейерных лент и резинотросовых лент. Это снизит вес конвейерной ленты, энергозатраты на ее эксплуатацию, повысит ее пожаробезопасность и долговечность.

Данные ленты позволят конструировать конвейеры большей длины без промежуточных приводов.

В настоящее время прошли успешные промышленные испытания теплостойких конвейерных лент производства ОАО «Курскрезинотехника»на Челябинском металлургическом комбинате ОАО «Мечел». Данные ленты изготовлены с базальтовой тканью под верхней обклад- 


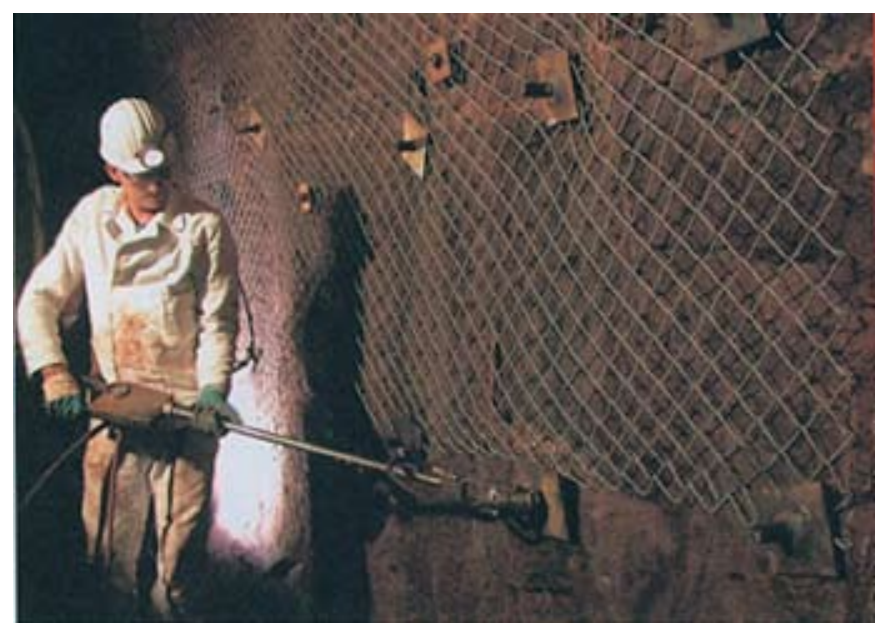

Puc. 1. Устройство для крепления горных выработок

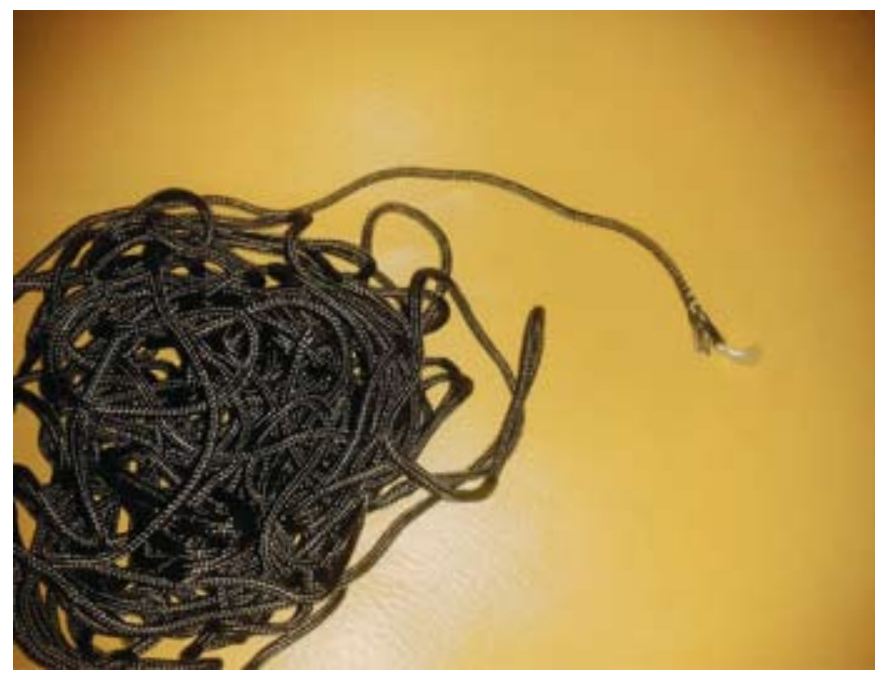

Puс. 3. Базальтакомпозитный шнур

кой для защиты несущих тканей от воздействия высоких температур.

Сетка из базальтового композита позволяет изготавливать футеровочные пластины повышенной прочности любой длины. Это очень важно при защите от износа больших поверхностей, например бункеров, вагонов, течек, поскольку позволяет избежать поперечных швов, являющихся основной причиной отрыва пластин от основы.

Применение базальтового композитного материала при изготовлении силовых гидроцилиндров обеспечит эко-

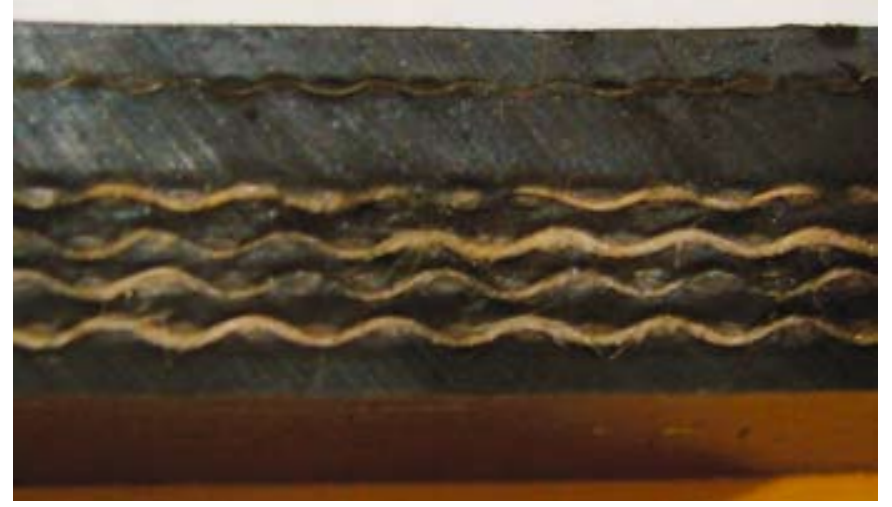

Puc. 5. Теплостойкая лента с базальтовой тканью

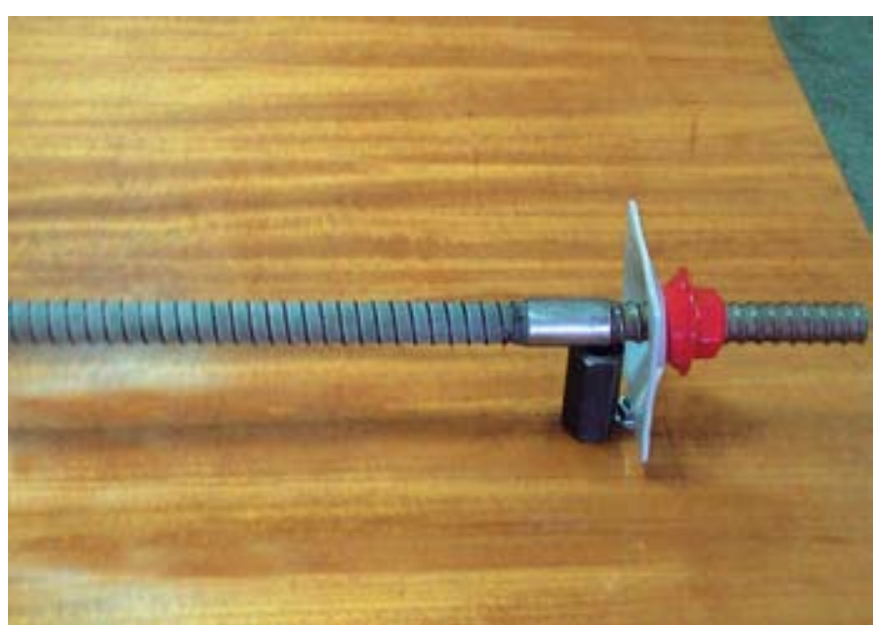

Puc. 2. Анкерная крепь из базальта

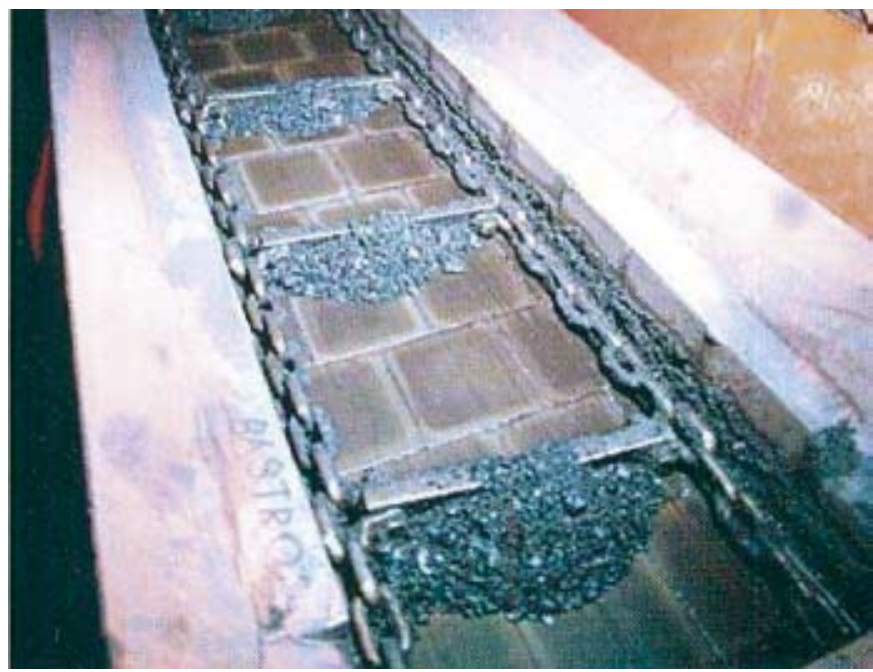

Pис. 4. Став скребкового конвейера

номию высоколегированных сталей, снизить затраты на их изготовление, уменьшит вес гидроцилиндров в 3 раза, обеспечит полную защиту от коррозии и гидроударов.

Применение базальтовых материалов при изготовлении демпфирующих балок для ленточных конвейеров позволяет увеличить коэффициент скольжения в 2 раза по сравнению с действующими полиэтиленовыми покрытиями и значительно увеличить срок их службы.

Ставы скребковых конвейерных перегружателей из базальтовой плитки дешевы и просты в изготовлении,

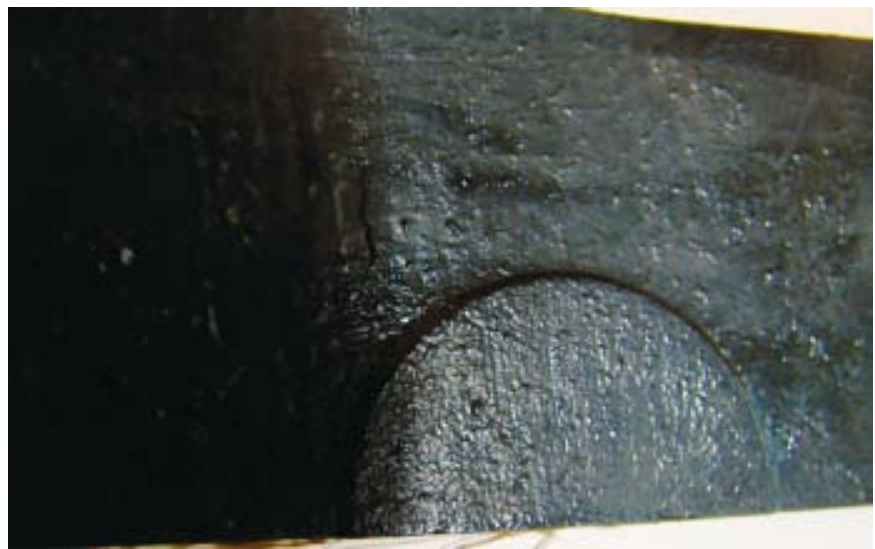

Рис. 6. Испытания на прожиг 


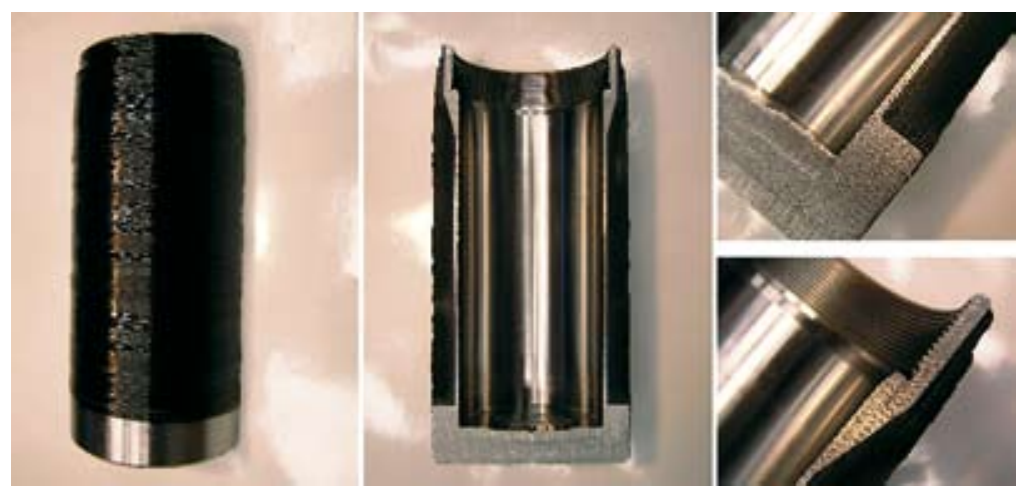

Puс. 7. Корпус гидроцилиндра с намоткой из базальта

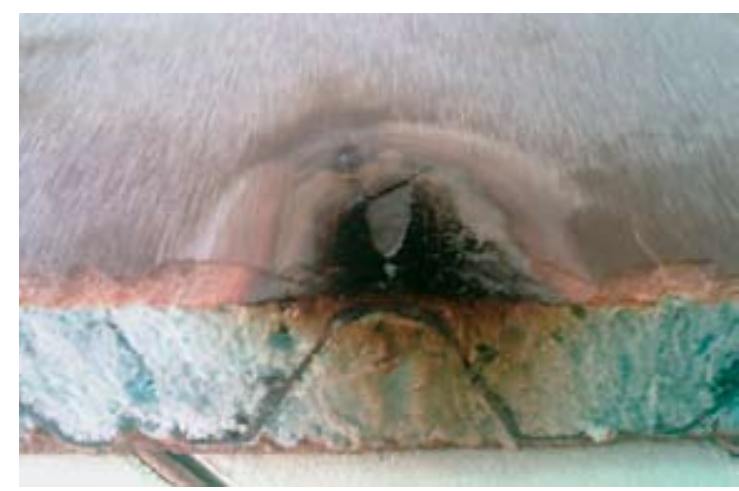

Puc. 8. Огнестойкая панель из базальтапластика

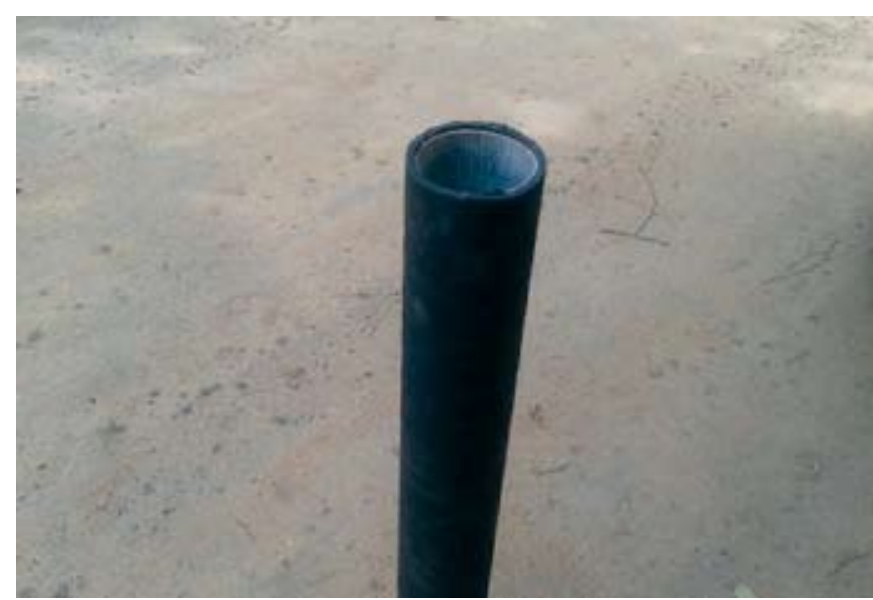

Рис. 9. Обечайка для ролика

обладают высокой износостойкостью несравнимой ни с одной из существующих марок сталей. Базальтовые ставы искробезопасны, что очень важно для угольных шахт.

Применение базальтовой плитки и базальтопластика особенно эффективно в обогатительном оборудовании - это производство, футеровки для спиральных классификаторов и мельниц, флотомашин, очистителей конвейерных лент.

В настоящее время прошли испытания конвейерные ролики с обрезиненной базальтакомпозитной обечайкой на подшипниках скольжения. Данные ролики не нагреваются и обеспечивают высокий коэффициент сцепления с конвейерной лентой, обладают высокой износостойкостью. Отсутствие смазочных материалов позволяет их использовать при любых минусовых температурах. Они не боятся запыленности и влаги.

ООО «Рекстром» разработал монтажные плиты из композитных материалов с применением базальта-пластика и базальтовой ткани, обладающие высокой пожаробезопасностью. Из данных плит можно изготавливать в шахтных условиях укрытия для шахтеров на случаи пожаров и выбросов метана.

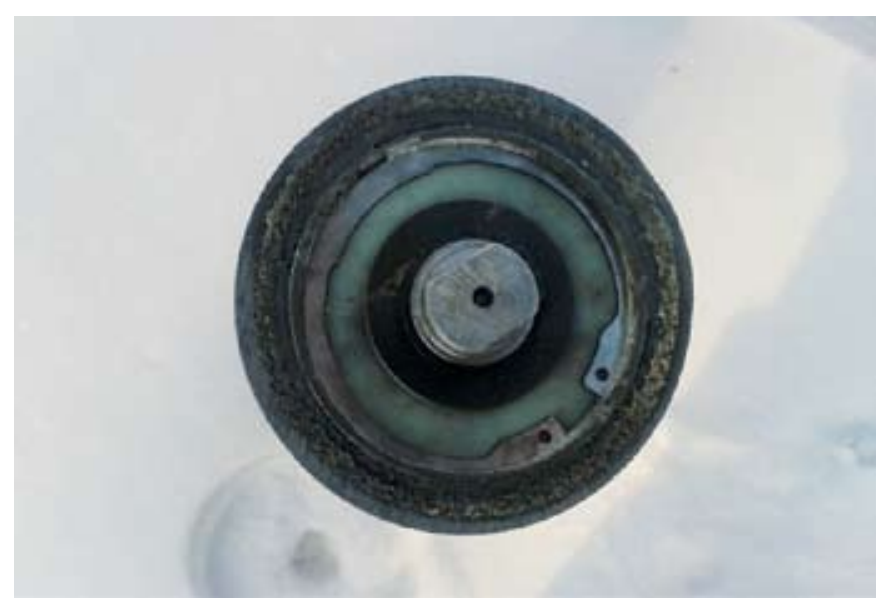

Рис. 10. Ролик из композита

Все разработки получили патент РФ и не имеют аналогов за рубежом.

Перспективы применения изделий из базальта и базальта-пластика в горной промышленности значительны. Однако ни одно из данных направлений не вошло в Долгосрочную программу развития угольной промышленности России до 2030 года.

Машиностроительные предприятия готовы внедрять данные технологии при условии, если им будут предоставлены акты промышленных испытаний. Это является основным сдерживающим фактором.

Поэтому в настоящее время остро стоит вопрос о проведении НИОКР по разработке технологий изготовления конкретных изделий из композитных материалов для конкретных условий эксплуатации, т.е. для шахтных условий, открытых способов добычи, проходки горных выработок, эксплуатации в условиях Крайнего Севера и Дальнего Востока.

Без поддержки Минобрнауки России, Минпромторга России и бизнеса внедрение композитных материалов в горнодобывающую промышленность весьма проблематично.

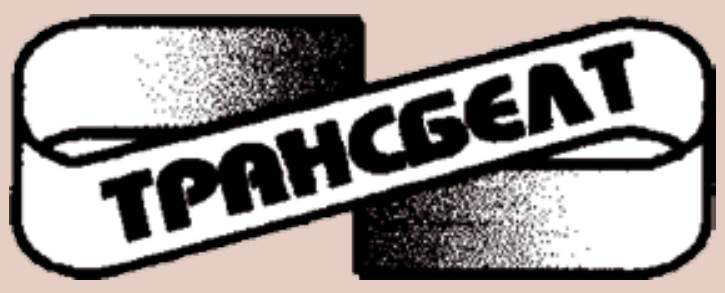

\section{ООО «Торговый дОМ «ТРАНСБЕЛТ»}

140014, Московская обл., Люберецкий район, г. Люберцы, 1-й Панковский проезд д. 3 тел. /факс: +7 (495) 557-72-74 www. transbelt.net; e-mail: transbelt@mail.ru 


\section{Экологические и практические аспекты использования шлака от сжигания угля} в производстве керамических материалов
на основе межсланцевой глины

Производство керамических материалов - одна из самых материалоемких отраслей народного хозяйства, поэтому рациональное использование топлива, сырья и других материальных ресурсов становится решающим фактором ее успешного развития в условиях проводимой экономической реформы. В связи с этим применение в керамических материалах отходов производства приобретает особую актуальность. Вовлечение промышленных отходов: шлака от сжигания угля и межсланцевой глины в производство керамических материалов без применения природных традиционных материалов кардинально меняет сырьевую базу России, снижает экологическую напряженность в регионах и позволяет получить высокомарочный кирпич. Использование отходов производства при получении кирпича способствует утилизации промышленных отходов, охране окружающей среды, расширению сырьевой базы для керамических материалов.

Ключевые слова: шлак от сжигания угля, межсланиевая глина, промышленные отходы, керамический кирпич, температура обжига, микроструктура.

Контактная информация: e-mail: 3375892@mail. ru

В золоотвалах ТЭС на территории России накопилось более 0,8 млрд т отходов, занимающих территорию более 20 тыс. га. При этом значительное количество золоотвалов располагается в черте городов. Используются же эти громадные отходы в очень небольшом количестве (в России в 1991 г. нашло применение лишь 7,7\% от ежегодного количества отходов тепловых электростанций) [1, 2].

В европейских странах и в США уровень утилизации золошлаковых отходов значительно выше. Так, использование золошлаковых отходов достигает: в США - $25 \%$, Великобритании - $53 \%$, Франции - $65 \%$, Германии - $75 \%[1,2]$.
С накоплением промышленных отходов нарушается экологическое равновесие. Земельным комиссиям приходится отводить участки для хранения отходов, которые могли бы быть использованы в градостроительстве или сельском хозяйстве [1-3]. Вместе с тем из отходов или из отходов в комбинации с природным сырьем могут быть изготовлены практически все основные строительные материалы [3. 4].

Производство строительных материалов - одна из самых материалоемких отраслей, в связи с этим применение отходов производства при изготовлении керамических материалов имеет особую актуальность [5].

\section{ЦЕЛЬ РАБОТЫ}

Целью работы являлось получение керамического кирпича из отходов топливно-энергетической промышленности без применения природных традиционных материалов.

В качестве отощителя (отощитель сокращает время сушки и усадочные напряжения в кирпиче) для производства керамического кирпича использовался шлак от сжигания угля Канско-Ачинского бассейна на Красноярской ТЭЦ-2.

Температура плавкости шлака от сжигания угля составляла: начало деформации $-1240^{\circ} \mathrm{C}$, размягчения $-1280^{\circ} \mathrm{C}$, жидкоплавкое состояние $-1300^{\circ} \mathrm{C}$. Химический состав представлен в табл. 1 .

Имея повышенные содержания оксидов железа, кальция и щелочей, шлак от сжигания угля будет способствовать спеканию керамического кирпича при относительно невысоких температурах обжига.

Рентгенофазовый состав исследуемых компонентов проводился на дифрактометре ДРОН-6 с использованием

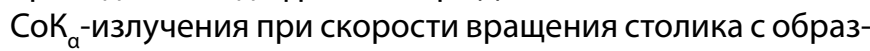
цом 1 град. /мин.

Таблица 1

Химический состав сырьевых материалов

\begin{tabular}{|c|c|c|c|c|c|c|c|}
\hline \multirow{2}{*}{ Сырьевой материал } & \multicolumn{7}{|c|}{ Содержание оксидов по массе, \% } \\
\hline & $\mathrm{SiO}_{2}$ & $\mathrm{Al}_{2} \mathrm{O}_{3}$ & $\mathrm{Fe}_{2} \mathrm{O}_{3}$ & $\mathrm{CaO}$ & MgO & $\mathbf{R}_{2} \mathbf{O}$ & П. п. п. \\
\hline Межсланцевая глина & $45-47$ & $13-14$ & $5-6$ & $11-13$ & $2-3$ & $3-4$ & $9-20$ \\
\hline Шлак от сжигания угля & 54,8 & 5,8 & 9,3 & 23,8 & 3,1 & 3,2 & - \\
\hline
\end{tabular}


a

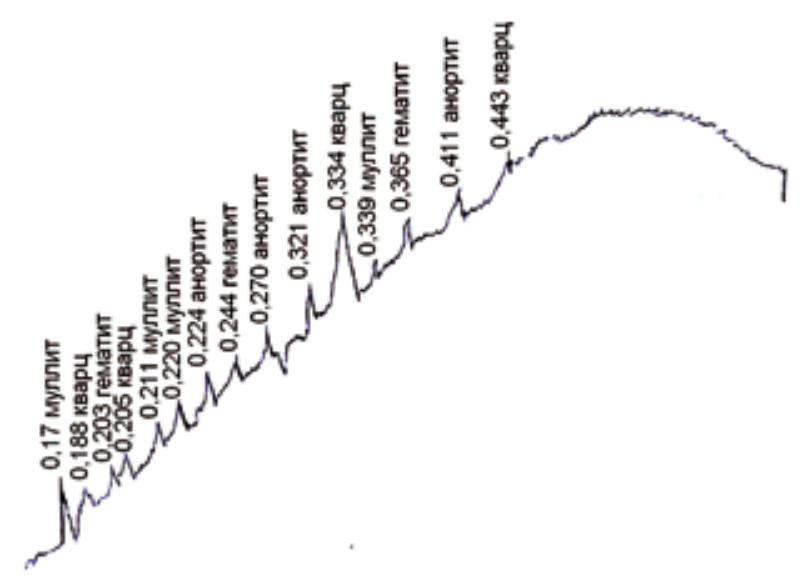

$\sigma$

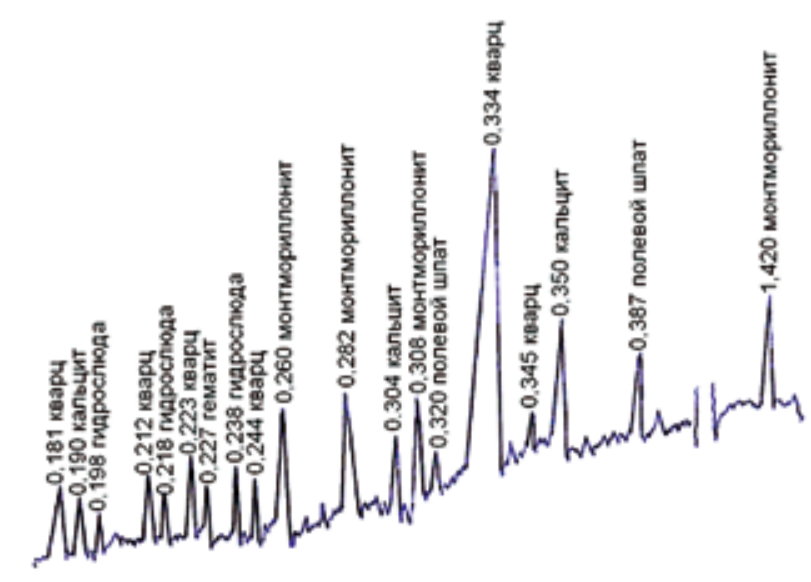

Puc. 1. Рентгенограммы исследуемых компонентов: $а$ - шлак от сжигания угля; б - межсланцевая глина

На рис. 1, а представлена рентгенограмма шлака от сжигания угля.

На дифрактограмме порошка шлака от сжигания угля отмечаются характерные интенсивные линии $(d / n=0,188 ; 0,205 ; 0,334$ и0,443нм) кварца, присутствиелинии $(d / n=0,17 ; 0,211 ; 0,220$ и 0,339 нм) обусловлено муллитом, линии $(d / n=0,203 ; 0,244$ и 0,365 нм) гематитом, линии $(d / n=0,224 ; 0,270 ; 0,321$ и 0,411 нм) анортитом.

Исследования минералогического состава шлака показали, что кристаллическая фаза в нем присутствует в незначительных количествах (не более 8-10\%). Аморфная фаза составляет порядка 60-80\%. $N_{c p}$. аморфной фазы равна 1,56-1,60, что, очевидно, связано с переходом части оксида железа в стекло и образование железистых стекол (рuc. 2, a).

Именно жидкая фаза является той средой, которая вначале накапливает щелочи, а затем, при достижении соответствующих условий (температуры, вязкости и др.), «передает» их зернам кварца [6-8], так как на рентгенограммах просматриваются только слабые пики кварца ( $d=0,443$ и 3,34 нм).

Микрогетерогенность силикатных расплавов обусловливает, в конечном счете, создание ионами в расплавах структурно упорядоченных групп, напоминающих строение кристаллической фазы, выделяющейся из расплава. Эти группы называют часто сиботаксическими [9]. Они, в сущности, и становятся при охлаждении центрами кристаллизации.

Наличие муллита $\left(3 \mathrm{Al}_{2} \mathrm{O}_{3} \cdot 2 \mathrm{SiO}_{2}\right)$ в исследуемом золошлаке будет способствовать и образованию муллита при обжиге керамического кирпича. Именно муллит придает основные физико-механические свойства керамическим материалам [4, 9].

В качестве глинистого компонента (пластичного материала) использовалась межсланцевая глина, которая является отходом при добыче горючих сланцев на сланцеперерабатывающих заводах и относится к высокопластичному глинистому сырью (число пластичности - 22-32) [6-8]. Химические составы исследуемых компонентов: оксидный и поэлементный представлены в табл. 1 и 2.

На дифрактограмме порошка межсланцевой глины отмечаются характерные интенсивные линии $(d / n=0,190$; 0,304 и 0,350 нм) кальцита, присутствие линии $(d / n=0,227$ нм) обусловлено гематитом, линии $(d / n=0,181 ; 0,212$; 0,$223 ; 0,244 ; 0,334$ и 0,335 нм) кварцем, линии $(d / n=0,198$; 0,218 и 0,238 нм) гидрослюдой, линии $(d / n=0,260 ; 0,282$;
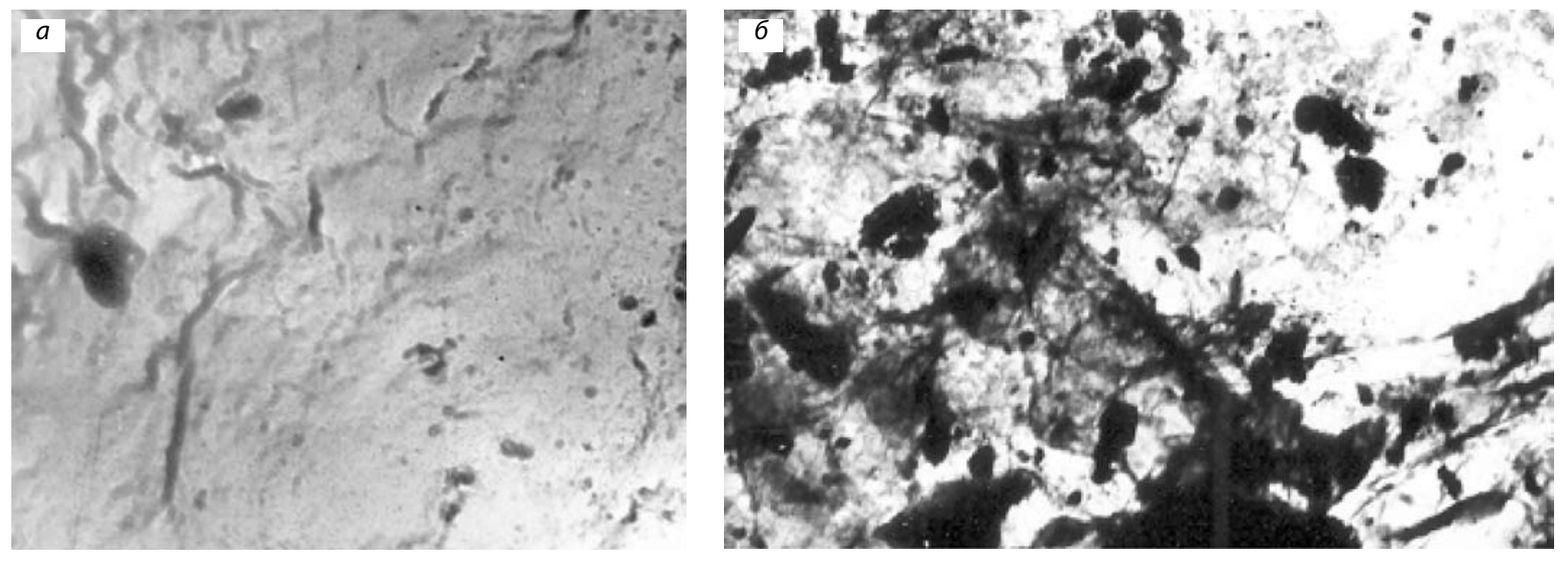

Pис. 2. Микроструктура исследуемых компонентов:

a- шлак от сжигания угля; б - межсланцевая глина. Увеличение х12000 
Составы керамических масс

\begin{tabular}{|l|c|c|c|}
\multicolumn{1}{c|}{ Сырьевые материалы } & \multicolumn{3}{c|}{ Содержание компонентов, мас. \% } \\
\cline { 2 - 4 } & $\mathbf{1}$ & $\mathbf{2}$ & $\mathbf{3}$ \\
\hline Межсланцевая глина & 70 & 60 & 50 \\
\hline Шлак от сжигания угля & 30 & 40 & 50 \\
\hline
\end{tabular}

Физико-механические показатели кирпича

Таблица 3

\begin{tabular}{|c|c|c|c|}
\hline \multirow{2}{*}{ Показатели } & \multicolumn{3}{|c|}{ Составы } \\
\hline & 1 & 2 & 3 \\
\hline Время сушки кирпича, ч & 64 & 58 & 52 \\
\hline Морозостойкость, циклы & 105 & 108 & 111 \\
\hline Механическая прочность на сжатие, МПа & 19,1 & 19,5 & 20,8 \\
\hline Механическая прочность на изгиб, МПа & 2,5 & 2,7 & 3,1 \\
\hline Усадка, \% & 8,4 & 8,9 & 9,2 \\
\hline
\end{tabular}

0,308 и 1,420 нм) монтмориллонитом, а линии $(d / n=0,320$ и 0,387 нм) полевым шпатом. Минералогический состав межсланцевых глин разнообразен, однако общим для них является наличие кремнезема, гидрослюды, монтмориллонита и кальцита (см. рис. 1, б).

Микроструктура межсланцевой глины представлена на puc. 2,6 .

\section{ТЕХНОЛОГИЯ ПРОИЗВОДСТВА КИРПИЧА}

Сырьевые материалы высушивались до влажности не более $5 \%$, затем измельчались до прохождения сквозь сито 0,63 мм. Высушенные сырьевые материалы тщательно перемешивали. Керамическую массу готовили пластическим способом при влажности 20-24\% (в зависимости от содержания глинистого компонента), из которой формовали кирпич. Кирпич-сырец высушивали до влажности не более $8 \%$ и затем обжигали при температуре $1050^{\circ} \mathrm{C}$. Изотермическая выдержка при конечной температуре составляла 60 мин.

В табл. 2 приведены составы керамических масс, а в табл. 3 - физико-механические показатели кирпича.

Как следует из табл. 2, керамические кирпичи получили из отходов топливно-энергетической промышленности без применения природного традиционного сырья. Полученный кирпич из предложенных составов имеет высокую морозостойкость и механическую прочность (см. табл. 3).

\section{выводы}

Использование отходов топливно-энергетической промышленности способствует:

- рациональному природопользованию за счет вовлечения отходов в производство керамических материалов;

- созданию энерго - и ресурсосберегающих технологий по производству строительных материалов;

- сохранению и рациональному использованию имеющихся природных сырьевых ресурсов;

- снижению экологической напряженности в регионе;
- утилизации промышленных отходов, охране окружающей среды и расширению сырьевой базы для получения строительных материалов;

- снижению себестоимости продукции.

\section{Список литературы}

1. Голицын М. В., Голицын А. М. Коксующиеся угли России и мира / Под ред. В.Ф. Череповского. - Справочник. - М.: Недра, 1996. - 239 с.

2. Всероссийское совещание по вопросам переработки и использования золошлаковых материалов тепловых электростанций / Материалы совещаний. - Новосибирск: PAО ЕЭС. - 2008. - 400 с.

3. Абдрахимов В.3. Вопросы экологии и утилизации техногенных отложений в производстве керамических композиционных материалов. - Самара: Самарская академия государственного и муниципального управления. - 2010. - 160 с.

4. Абдрахимов В.3., Абдрахимова Е. С., Абдрахимов Д. В., Абдрахимов А. В. Применение техногенного сырья в производстве кирпича и черепицы. - СПб.: Недра. - 2004. $126 \mathrm{c}$.

5. Абдрахимов В. 3., Рощупкина И. Ю., Абдрахимова Е.С., Колпаков А. В. Использование отходов горючих сланцев в производстве теплоизоляционных материалов без применения природного сырья //Экология и промышленность России. - 2012. - №3. - С. 28-31.

6. Абдрахимова Е.С., Абдрахимов В.3. Получение керамического кирпича из отходов производства //Экология производства. - 2012. - №10. - С. 36-40.

7. Абдрахимов В. 3., Абдрахимова Е. С. Фазообразование при обжиге керамического материала из бейделлитовой и межсланцевой глины //Материаловедение. - 2013. №1. - С. 51-58.

8. Абдрахимов В. 3., Рощупкина И. Ю., Абдрахимова Е.С. Процессы горения углерода при обжиге теплоизоляционного материала из отходов горючих сланцев //Кокс и химия. - 2012. — №11. - С. 35-41.

9. Куколев Г. В. Химия кремния и физическая химия силикатов. - М.: Высшая школа, 1966. - 464 с. 


\section{ХРОНИКА СОБЫТИЯ ФАКТЫ}

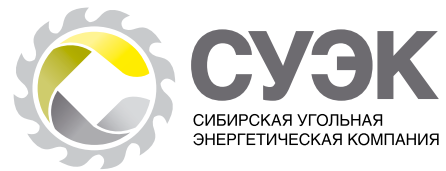

Наша справка

ОАО «Сибирская угольная энергетическая компания» (СУЭК) крупнейшее в России угольное объединение по объему добычи. Компания обеспечивает около $30 \%$ поставок угля на внутреннем рынке и примерно $25 \%$ российского экспорта угля. ФилиалыидочерниепредприятияСУЭК расположены в Забайкальском, Красноярском, Приморском и Хабаровском краях, Кемеровской области, в Бурятии и Хакасии.

\section{Ванинский балкерный терминал установил рекорд суточной погрузки на суда}

С 14 на 15 марта 2014 г. Ванинский балкерный терминал (ЗАО «Дальтрансуголь») достиг нового рекорда погрузки на флот, перевалив за сутки 110 тыс. т угля.

По словам исполнительного директора $3 \mathrm{AO}$ «Дальтрансуголь» Владимира Шаповаля, достижение такого результата стало возможным благодаря проведенной в 2013 г. модернизации оборудования в терминале, его качественной подготовки к эксплуатации в зимний период, повышению профессионального уровня докеров, организации соревнований среди бригад на лучший месячный результат по погрузке на флот, а также переходу бригад на работу с учетом коэффициента трудового участия и внедрению новой системы премирования докеров за скорость и качество погрузки угля на флот.

Сегодня Ванинский терминал — это порт круглогодичного действия, имеющий прямой выход на две независимые железнодорожные магистрали - Транссибирскую (Транссиб) и Байкало-Амурскую (БАМ), по которым он связан со всеми точками России.

Ввод в эксплуатацию Ванинского терминала состоялся в конце 2008г. ОАО «СУЭК» построила терминал с целью ликвидации дефицита портовых мощностей на Востоке страны и поставок угля на растущий рынок стран Азиатско-Тихоокеанского региона.

\section{Компания Corum изготовит вентиляторы нового поколения и построит шахтную вентиляторную установку «под ключ»}

Компания Corum заключила с Запорожским железорудным комбинатом первый контракт на изготовление осевых одноступенчатых вентиляторов главного проветривания нового поколения и строительство современной шахтной вентиляторной установки «под ключ».

В рамках проекта компания выполнит весь комплекс проектно-изыскательских и строительно-монтажных работ - от геодезических исследований грунта до при-

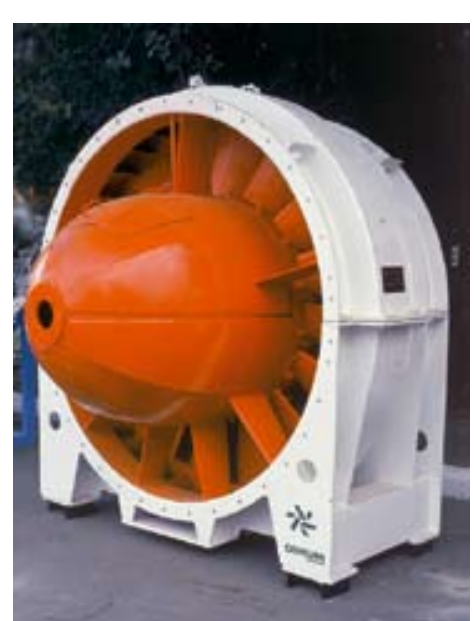

емочных испытаний и сдачи установки в эксплуатацию.

Также для клиента будут произведены высокооборотные вентиляторы, которые по своим конструктивным решениям и аэродинамическим параметрам не имеют аналогов в странах СНГ. Следует отметить, что в их комплектации будут применены энергосберегающие

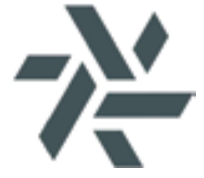

технологии - установлена современная система автоматизации с частотно-регулируемым приводом, что в комплексе позволит снизить энергозатраты на $25 \%$.

Наладка и сдача объекта в эксплуатацию клиенту планируется в декабре текущего года.

По словам директора Дивизиона инфраструктурных проектов Corum Group Владимира Мерзликина, подписание этого контракта - очередной шаг на пути движения компании к выполнению проектов под «ключ».

\section{Наша справка}

Компания Corum (ранее НПК «Горные машины») входит в состав крупнейшей в Украине финансово-промышленной группы «Систем Кэпитал Менеджмент» (СКМ) и является экспертом в горнодобывающем бизнесе. Деятельность компании сосредоточена на предоставлении высокотехнологичных комплексных решений, производстве и сервисе оборудованияв области добычи, переработки итранспортировки полезных ископаемых, а также строительстве шахт. В Corum входят шесть заводов в Украине, ремонтные площадки в Украине и России, торговые компании в Украине, России, Казахстане, Вьетнаме и Польше. Сайт компании: www. corum. com. 


\section{Порт Шахтерск отгрузил потребителям более 83 тыс. т угля}

Подошедшие с севера Сахалина тяжелые льды не позволяют выходить в море буксирам и судам портового флота морского угольного терминала Шахтерск. В настоящий момент докеры заняты береговыми работами по подготовке береговых сооружений, техники и флота кпредстоящей навигации.

Тем не менее шахтерские докеры с начала 2014 г. смогли отгрузить более 83 тыс. т. Погрузочные работы на рейде порта будут продолжены при улучшении ледовой обстановки.

С 2013 г. порт Шахтерск (ООО «Обогатительная фабрика») находится под контролем ООО «Восточная горнорудная компания». В группу также входит ООО «Сахалинуголь-2» (Солнцевский угольный разрез). В минувшем году впервые через порт Шахтерск было отгружено более 1,2 млн т угля. Прирост по сравнению с 2012 г. составил более $100 \%$. В 2013 г.докеры «Восточной горнорудной компании» впервые в истории Сахалинской области начал принимать к отгрузке балкеры дедвейтом 55 тыс. т. Это стало возможным благодаря серьезной модернизации берегового погрузочного комплекса и приобретению мощного портового флота дедвейтом от 1,7 до 3,5 тыс. т.

Наша справка.ООО «Сахалинуголь-2» (Солнцевский угольный разрез) и 000 «Обогатительная фабрика» (порт Шахтерск) с 2013 г. входят в состав ООО «Восточная горнорудная компания». Объем добычи угля ООО «Сахалинуголь-2» в 2013 г. превысил 1,8 млн $m$ (в 2012 г. - 1,2 млн т). Объем отгрузки угля ООО «Обогатительная фабрика» в 2013 г. составил 1,235 млн т (в 2012 г. - около 600 тыс. m).

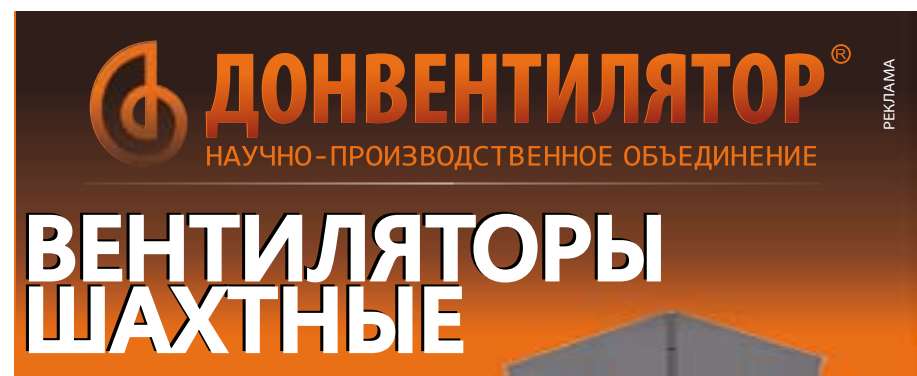

Вентиляторы осевые шахтные местного проветривания ВМЭВО с диапазоном подачи (производительности) $3,6-34 \mathrm{~m}^{3} / \mathrm{c}$

Вентиляторы осевые шахтные встречного вращения местного проветривания ВМЭВО-ВВ с диапазоном подачи (производительности) $2-37 \mathrm{~m}^{3} / \mathrm{c}$

Вентиляторы осевые шахтные главного проветривания ВО-Д размерного ряда ВО-12...40ДР и ВО-12...40ДН

Вентиляторы центробежные шахтные главного проветривания ВЦ и ВЦД размерного ряда от ВЦ- 11 до ВЦД- 47,5

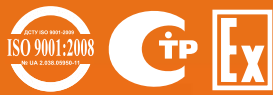

ООО «НПО «Донвентилятор»

Украина, 83030, г. Донецк, ул. Тамбовская 50 «Г»

Тел/факс: + 38 (062) $3875698 ; 3875699$;

$3875670 ; 3875672 ; 3875677$

e-mail:donvent@ukr.net

http://www.donvent.com

Пресс-служба ОАО ХК «СДС-Уголь» информирует На разрезе «Сибэнергоуголь» запустили новый участок

ООО «Сибэнергоуголь» завершил горнокапитальные работы на участке «Ананьинский-Западный» производственной мощностью 1,5 млн т угля в год и запустил его в эксплуатацию.

Балансовые запасы нового участка составляют 22,9 млн т угля. В строительство и развитие участка «Сибирский Деловой Союз» направил более 490 млн руб., в том числе более 100 млн руб. на проектно-изыскательские и геологоразведочные работы, более 390 млн руб. на строительство объектов инфраструктуры.

Разрез «Сибэнергоуголь» - единственное угледобывающее предприятие Холдинговой компании «СДС-Уголь», специализирующееся на добыче антрацитовых углей. $100 \%$ продукции поставляется иностранным потребителям. В настоящее время добыча углей редких марок «А» и «Т» ведется на основном участке «Бунгурский Южный».

Согласно плану перспективного развития «Ананьинский Западный» выйдет на производственную мощность в 1,5 млн т угля к 2018 г. Такой объем добычи позволит эксплуатировать участок в течение 22 лет.
В рамках реализации инвестиционной программы компании «СДС-Уголь» планируется расширение парка оборудования разреза «Сибэнергоуголь». Помимо развития участка «Ананьинский Западный» инвестиционная программа компании «СДС-Уголь» предусматривает реконструкцию и расширение инфраструктуры разреза «Сибэнергоуголь». На реконструкцию станции «Листвяги» и объектов инфраструктуры предприятия «Сибирский Деловой Союз» направит 277 млн руб.

В 2013 г. горняки «Сибэнергоуголь» добы-
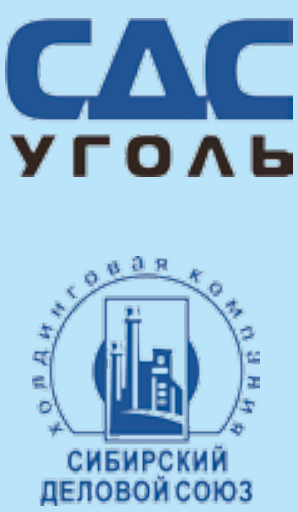
ли 1,35 млн т угля. Это на 120 тыс. т больше показателей прошлого года.

Наша справка

ОАО ХК «СДС-Уголь» входит в тройку лидеров отрасли в России. По итогам 2013 г. предприятия ОАО ХК «СДС-Уголь» добыли 24,5 млн $т$ угля. 86,2\% добываемого угля поставляется на экспорт. ОАО ХК «СДСУголь» является отраслевым холдингом ЗАО ХК «Сибирский Деловой Союз». В зону ответственности компании входят 25 предприятий, расположенных на территории Кемеровской области. 


\section{Новые подземные самосвалы от Sandvik Mining прошли испытания в Австралии}

Две новых модели подземных самосвалов от Sandvik Mining прошли испытания в Австралии и показали высокие результаты в области безопасности, производительности и экономичного

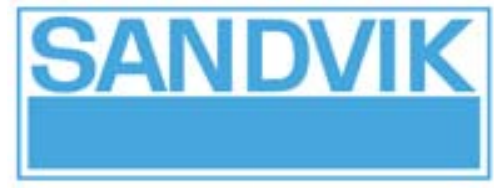

инструктора. Дисплей автоматизированной системы управления содержит всю необходимую информацию и позволяет оператору сосредоточиться на вождении. Кроме того, комфорт обеспечивают регулируемое сиденье и подрасхода топлива. Впервые представленные в 2012 г. на американской выставке MINExpo, самосвалы TH551 и ТН663 помогают работать в шахтах без простоев и обеспечивают максимальный комфорт для операторов оборудования.

Подземные самосвалы ТH551 и ТН663 грузоподъемностью соответственно 51 и 63 тразработаны для эксплуатации в выработках размером 5х5 и 6х6 м. Конструкция машин позволяет оптимально организовать работу оператора и обслуживающего персонала на руднике, обеспечивая высокую производительность.

Модель Sandvik TH663 разработана специально для совместной работы с подземным погрузчиком Sandvik LH621, модель ТН551 спроектирована для работы с погрузчиком LH517. Габариты новых самосвалов позволяют максимально эффективно работать с этими погрузчиками, обеспечивая возможность трехковшового погрузочного цикла, что увеличивает эффективность погрузочно-доставочных работ и повышает общий уровень производительности.

Особое внимание при создании самосвалов было уделено комфорту тех, кто работает с оборудованием. Усовершенствованная и увеличенная на $35 \%$ по сравнению с предыдущими моделями кабина оператора оснащена четырехточечным ремнем безопасности и сиденьем для

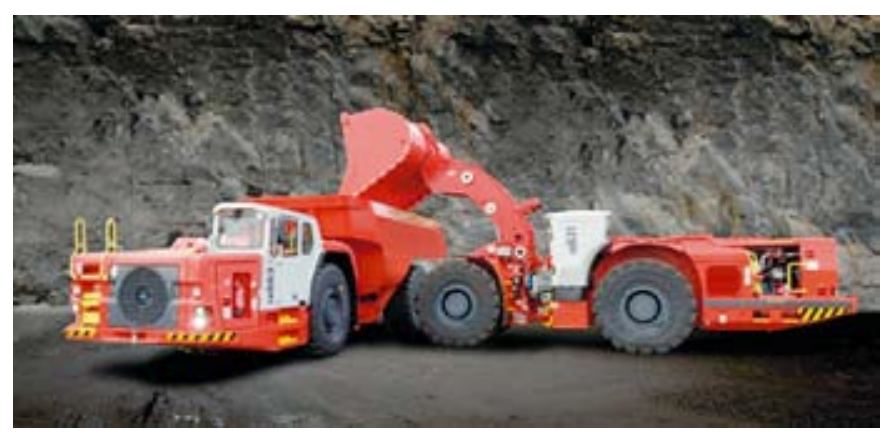

веска передней полурамы - новшество для самосвалов такого типа. А благодаря небольшому холодильнику, соединенному с системой климат-контроля, оператор может взять с собой еду и напитки.

Но важнее всего для разработчиков ТН551 и ТН663, конечно же, безопасность. Каждый из самосвалов оснащен более чем 60 системами безопасности для защиты оператора, обслуживающего персонала и самого самосвала, в том числе системами защиты кабины от переворота и падающих предметов. Ежедневное обслуживание оборудования можно проводить с уровня почвы. Кроме того, конструкция самосвалов позволяет в кратчайшие сроки заменять крупные узлы - например компоненты трансмиссий. Также была решена проблема, связанная с частыми проколами шин. Во-первых, благодаря системе контроля за состоянием шин теперь можно избежать сдутия, прокола или возгорания шины. А, во-вторых, ТН551 и ТН663 могут быть дополнительно оборудованы системой бортовых домкратов, обеспечивающей быструю и безопасную замену шин.

Sandvik Mining - одно из бизнес-подразделений группы Sandvik, занимающее третью часть всей группы компаний. Подразделение является одним из мировых лидеров в предоставлении инжиниринговых решений и производстве оборудования в области геологоразведки, горной промышленности и транспортировки сыпучих материалов. Оборудование и инструмент Sandvik применяются как для открытых, так и для подземных горных работ навсех этапах производственного прочесса в горнодобывающей промышленности.

Подразделение компании Sandvik Mining, работающее на территории СНГ, занимается поставкой и сервисом оборудования, а также продажей запасных частей для горнодобывающей отрасли.

\section{Администрация Кемеровской области информирует Кузбасс готов принять шахтеров Донбасса}

Губернатор Кемеровской области А. Г. Тулеев, находясь в Москве в Кремле на церемонии подписания Президентом России В.В. Путиным с представителями властей Крыма Договора о вхождении Республики Крым и города Севастополя в состав Российской Федерации, отметил, что «сегодня была восстановлена подлинная историческая справедливость. Это наш всеобщий праздник. Подвиг нашего президента, наших людей станет одной из светлых страниц в истории современной России».
Кроме того, А.Г. Тулеев сообщил, что Кузбасс готов принять своих коллег, в первую очередь из Донецкой области, из Крыма. «Унас 26 тыс. вакансий, в том числе не хватает шахтерских коллективов, горняцких. И мы говорим, ребята, давайте приезжайте к нам челыми бригадами. А мы уже обеспечим вас жильем, работой. Какая разница, где уголь добывать - в Донбассе или в Кузбассе? Тем более, что существует шахтерское братство Донбасс - Кузбасс». 


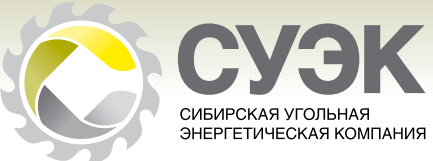

СуэК вручена награда победителя конкурса РСПП «Лидеры российского

бизнеса» в основной номинации «За высокую социальную ответственность бизнеса»

На ежегодной Неделе российского бизнеса, проводимой Российским союзом промышленников и предпринимателей (РСПП), 20 марта 2014 г. были вручены награды победителям Всероссийского конкурса «Лидеры российского бизнеса: динамика и ответственность - 2013».

Торжественная церемония прошла в рамках съезда РСПП под руководством Президента Союза Александра Шохина. В работе съезда принял участие Президент Российской Федерации Владимир Путин.

ОАО «СУЭК» было объявлено победителем Конкурса в основной номинации «За высокую социальную ответственность бизнеса». Награда была вручена генеральному директору ОАО «СУЭК» Владимиру Рашевскому.

Один из самых авторитетных и престижных в стране, ежегодный конкурс РСПП «Лидеры российского бизнеса» призван содействовать устойчивому развитию компаний, которое отвечает долгосрочным экономическим интересам бизнеса и ежегодно определяет динамично развивающиеся организации на основе рейтинговых оценок.

OAO «Мечел» (NYSE: MTL), ведущая российская горно-добывающая и металлургическая компания, информирует

\section{ОАО «Мечел» заключил}

\section{с Внешэкономбанком соглашения} по второй и третьей кредитным

\section{линиям на финансирование развития Эльгинского угольного комплекса}

14 марта 2014 г. ОАО «Мечел» (NYSE: MTL) сообщило о подписании проектной компанией ООО «Эльгауголь» (входит в группу «Мечел») и ГК «Банк развития и внешнеэкономической деятельности (Внешэкономбанк)» соглашений о выделении второй и третьей кредитных линий проектного финансирования на развитие первой очереди Эльгинского угольного комплекса в размере соответственно 2,085 млрд и 418,7 млндол. США.

Вторая кредитная линия в размере 2,085 млрддол. США будет направлена на финансирование строительства объектов Эльгинского угольного комплекса до достижения производственной мощности по добыче и обогащению угля в объеме 11,7 млн т рядового угля в год, а также на

\section{BEHTIIPOM | ono-Am,}

\section{Вентиляторы шахтные:}

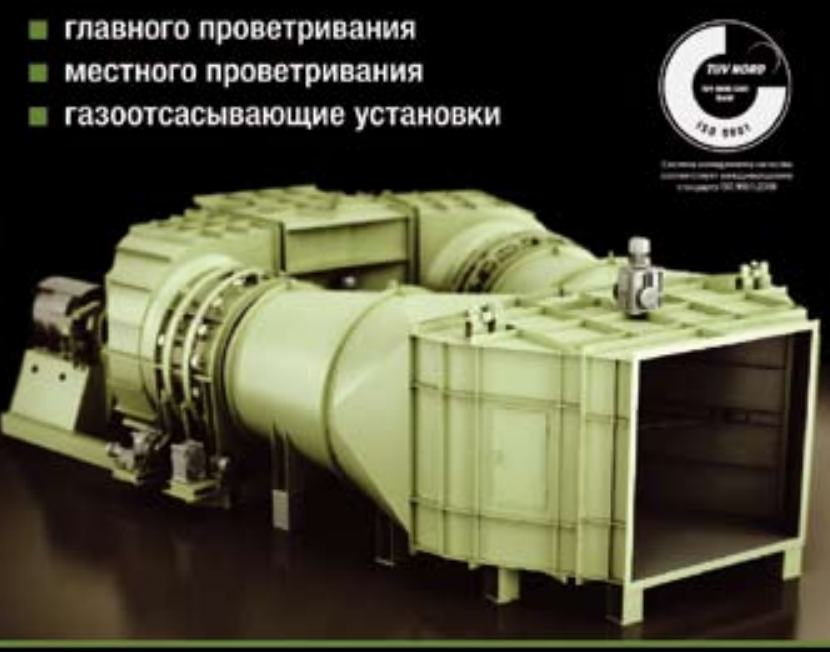

Свердловская область, г. Артемовский, уп. Садовая, 12

Ten: $\quad(34363) 58-112,58-105,58-100$

are $\quad(34363)$ 58-158

E-mak ventprom@ventprom.com

meb: www.ventprom.com

Представительство в г. Новокузнецке:

Ten: $\quad+7$ 913-136-37-75, +7 923-622-99-73

6-mak ilnar_ventpromgmail.ru завершение работ по увеличению пропускной способности железнодорожной ветки Улак-Эльга.

Третья кредитная линия в размере 418,7 млн дол. США будет предоставлена с целью финансирования затрат на уплату процентов и комиссий Внешэкономбанка по второй кредитной линии до момента ввода в эксплуатацию объектов первой очереди Эльгинского угольного комплекса, а также с целью погашения бридж-кредита на сумму 150 млндол. США (первая кредитная линия), предоставленного ООО «Эльгауголь» в октябре 2013 г.

В залог по данным кредитным линиям будет предоставлено 49\% долей в ООО «Эльгауголь», а также движимое и недвижимое имущество проектной компании. Внешэкономбанк также приобретет 0,01\% уставного капитала ООО «Эльгауголь» с последующей обратной продажей.

Сделка на предоставление ОАО «Мечел» проектного финансирования в объеме 2,5 млрддол. США была одобрена Наблюдательным советом Внешэкономбанка в сентябре 2013 г. Срок финансирования составляет 13,5 лет.

«Мы очень ченим сотрудничество с Внешэкономбанком, который оказывает поддержку нашей компании в достаточно непростой период для отрасли и мирового финансового рынка. Благодаря этому кредиту мы полностью решили вопрос финансирования Эльгинского проекта, который будет развиваться вне зависимости от колебаний конъюнктуры на сырьевыхрынках», - сказал старший вице-президент ОАО “Мечел» по финансам Станислав Площенко. 


\section{Академия горных наук 1993 2013}

Академия горных наук, имеющая статус межрегиональной неправительственной организации, учреждена в 1993 г. в качестве представительного органа научного горного сообщества в целях содействия ускорению перехода российского горнопромышленного комплекса на инновационный путь развития в условиях глобализации минерально-сырьевого рынка. Инициаторами создания и организаторами Академии стали министр угольной промышленности СССР (1965-1985 гг.), Герой Социалистического Труда Борис Федорович Братченко и академик РАН, лауреат Государственной премии Российской Федерации, премий Совета Министров СССР и Правительства Российской Федерации, премии Ленинского комсомола, заслуженный деятель науки и техники Юрий Николаевич Малышев.
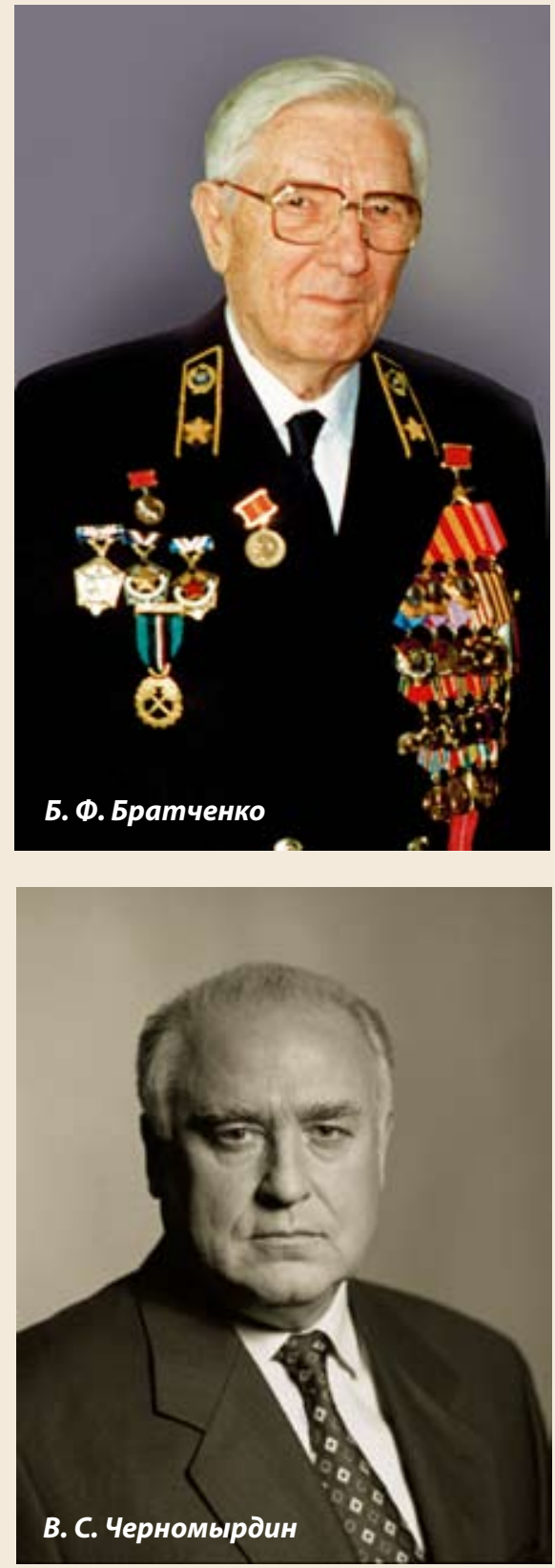

В 1993 г., когда председателем Правительства Российской Федерации был назначен Виктор Степанович Черномырдин, одним из первых его решений было создание государственного предприятия «Росуголь». Возглавил это предприятие Ю.Н. Малышев. В этот момент никто кроме него не мог собрать такой команды из опытных шахтерских генералов, политиков и молодых ученых, чтобы сделать прорыв для угольной промышленности и спасти все, что можно, в сложившейся ситуации. Даже сегодня не найти такой сильной команды ни в одной государственной структуре. Эта команда разработала и реализовала программу реструктуризации угольной промышленности страны. Что и спасло эту отрасль от разрушения.

В то время рушилось все, что было создано страной десятилетиями, - станкостроение, социальная сфера, экономические связи с республиками, погибала наука. Обладая стратегическим, государственным мышлением, бывший министр угольной промышленности СССР (1965-1985 гг.) Б. Ф. Братченко и Ю.Н. Малышев в долгих беседах пришли к выводу, что необходимо создать общественную организацию, которая бы объединила и поддержала научных и производственных специалистов. Так была создана в 1993 г. Межрегиональная неправительственная общественная организация Академия горных наук (АГН) с благословения и при поддержке Председателя Правительства Российской Федерации В.С. Черномырдина.

Академия горных наук объединила в себе ученых и производственников всех отраслей минерально-сырьевого комплекса, а именно представителей нефтяной, газовой и угольной промышленности, горнодобывающих отраслей черной, цветной металлургии и горно-химического сырья, урана, редкоземельных элементов и строительных материалов.

Вот уже 20 лет Президентом Академии является академик РАНЮ.Н. Малышев. Членами АГН стали вся креативная команда «Росугля», ученые институтов, академики РАН, некоторые руководители горнодобывающих и станкостроительных предприятий России. Были созданы отделения АГН по всей стране. В это же время государственное предприятие «Росуголь» оказало неоценимую финансовую поддержку очень многим научным институтам страны. Это, кстати, спасло многие НИИ от закрытия и потери кадров. И это надо помнить сегодня, чтобы оценить роль и деятельность АГН в сохранении науки для горных предприятий.

В истории становления, развития и укрепления авторитета АГН среди ученых, политиков, горнопромышленников России и зарубежных стран на одном из самых почетных мест стоят имена советского и российского государственного деятеля, экс-главы «Газпрома», лауреата Государственной премии СССР Рема Ивановича Вяхирева; советского и российского ученого, первого вице-прези- 
дента АГН, лауреата Государственно премии СССР, заслуженного изобретателя России Евгения Александровича Котенко; заслуженного деятеля науки РФ, профессора, доктора технических наук, главного ученого секретаря Академии горных наук Виктора Алексеевича Харченко.

После распада СССР угольное машиностроение на $60 \%$ оказалось на Украине, на $20 \%$ - в Казахстане. В это время члены АГН во главе с Ю.Н. Малышевым многое сделали для сохранения угольного машиностроения. Появились таможенные барьеры. России нужно было срочно создавать свою горную технику. Члены АГН обратились к заводам военно-промышленного комплекса (конверсия поставила уникальные оборонные предприятия на колени - продукцию девать некуда). На одном из таких уникальных заводов в Кемеровской области удалось организовать производство нового механизированного комплекса, а на заводе «Красные баррикады» (г. Волгоград), организовали производство другого комплекса. Оборонная промышленность в это время сохраняла замечательные кадры и технологии. При толковом подходе она могла бы вытащить всю экономику страны. Но не случилось. Вопрос лишь в востребованности этих разработок, в заказе государства.

В АГН учреждены премии имени выдающихся ученых: М.И. Агошкова, А.П. Крылова, С. А. Оруджева, И.Н. Плаксина, А. М. Терпигорева, А. К. Харченко, Н.В. Мельникова и премия «За выдающийся вклад в развитие горных наук и промышленности».

В составе АГН работают девять подразделений: Дальневосточное, Приволжское, Северо-Западное, Сибирское, Уральское, Московское, КМА, Тульское, Южное, а также научные центры (гг. Калининград, Якутск).
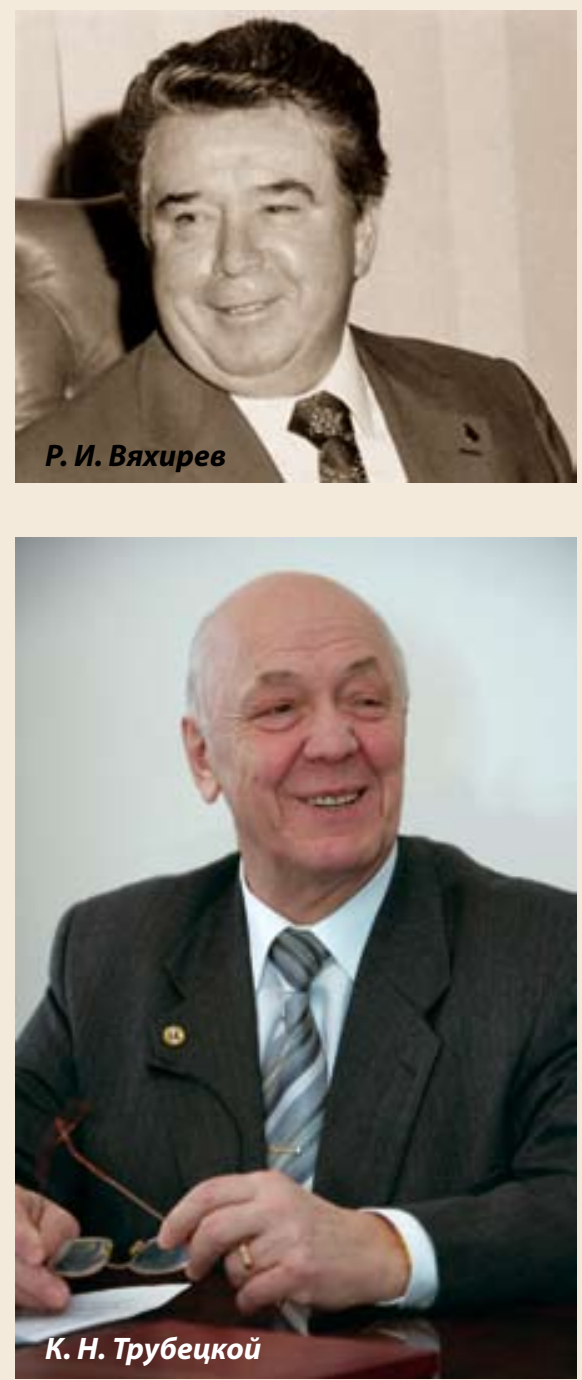
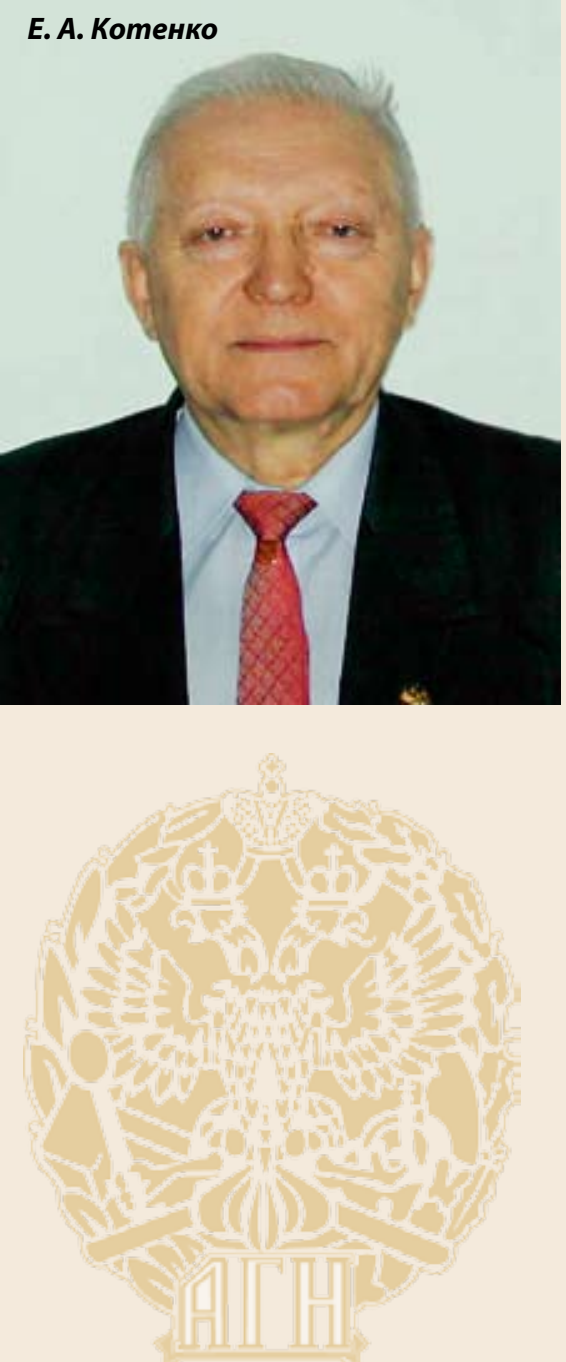
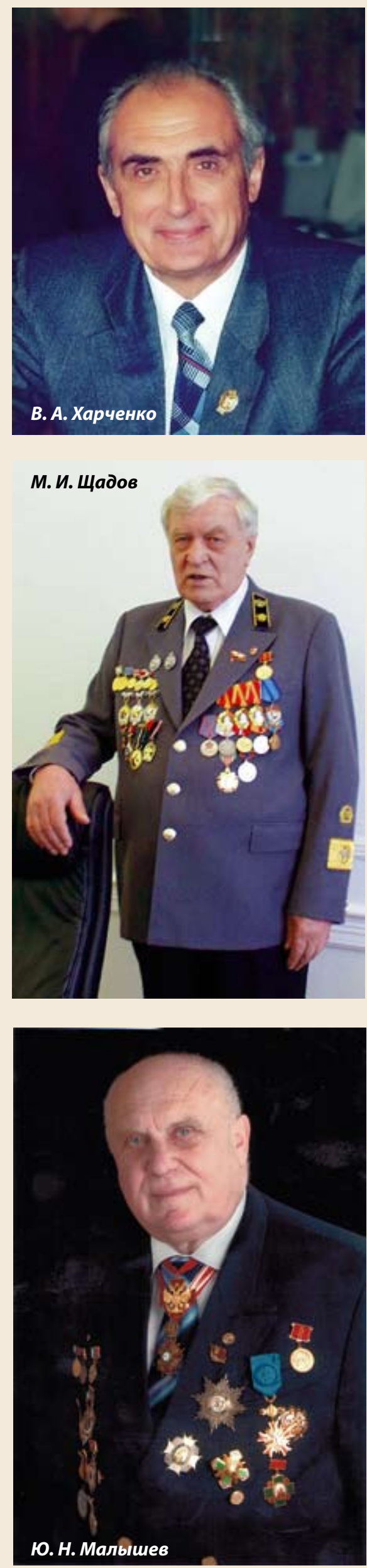
К настоящему времени в составе Академии горных наук 1041 действительных членов, 110 почетных и 139 иностранных членов, 238 академических советника. В их числе известные бизнесмены и ученые, специалисты и государственные служащие высокого ранга.

И, как сказал в своем докладе президент АГН Ю. Н. Мaлышев - «пора уступать дорогу молодым». Он отметил, что спустя 20 лет работы Академии можно сделать объективный вывод: работали не зря и многого достигли - сплотили в своем научном сообществе большинство ученых и специалистов, широко известных своими научными трудами и достижениями в области новой техники. Удалось преодолеть отраслевую разобщенность и объединить интеллектуальный потенциал ради прогресса практически во всех сферах горного дела. Тем самым создан надежный задел для дальнейшего совершенствования организации и результативности нашей работы. А для этого уже должны прийти молодые.

— «Пришли в мир другие люди, с другим менталитетом, с другими принципами. Сейчас мы активно занимаемся подготовкой второго молодежного форума лидеров горного дела. Мы уже видели их профессионализм и активность. Полагаю, что нужно сделать молодежную секцию или отделение как продолжение АГН. Пришло время обновления. Будем заниматься молодыми» — сказал Ю. Н. Малышев.
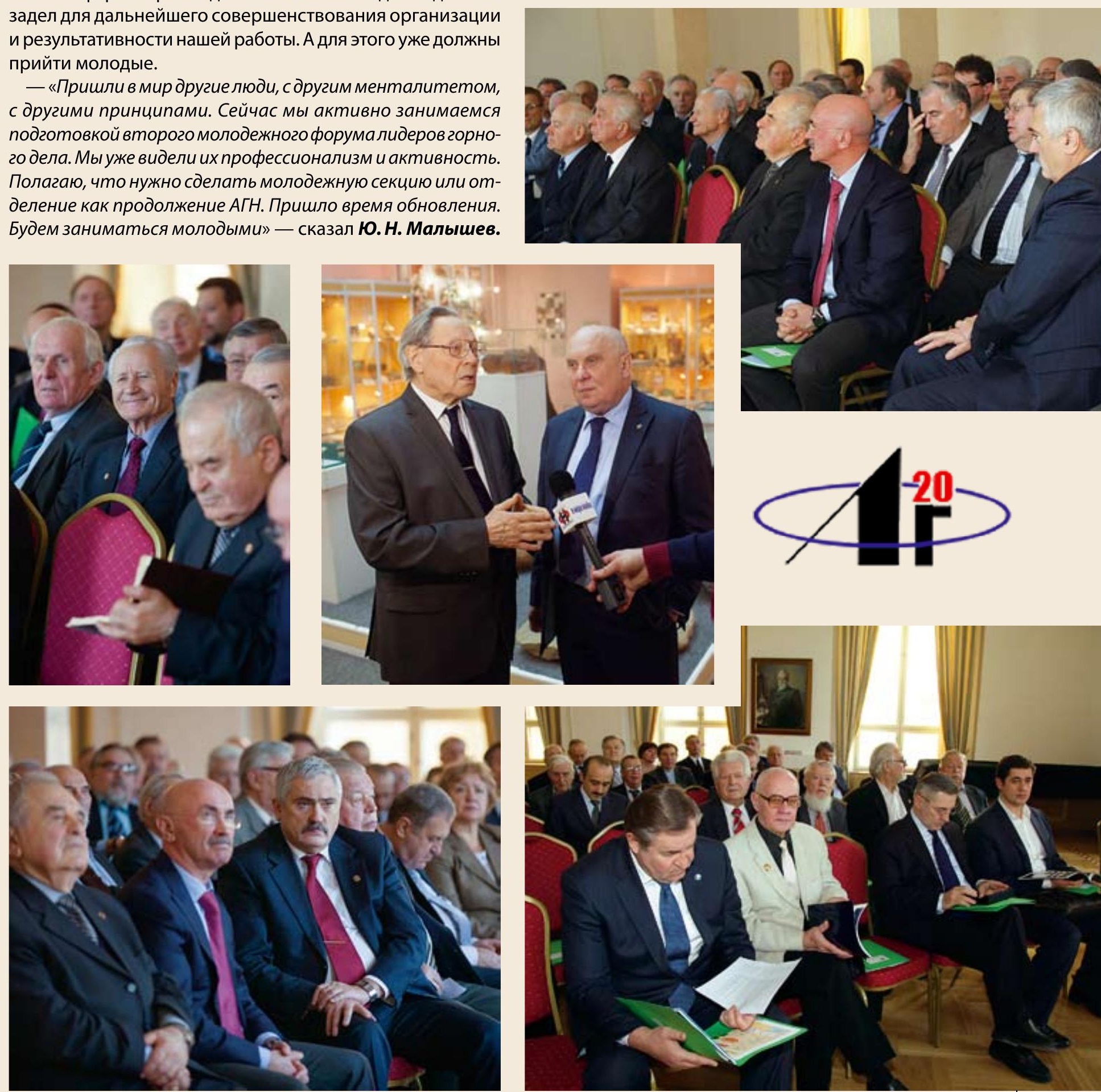
28 января 2014 г.

в актовом зале

Московского

государственного

горного университета

торжественно открылся

XXII Международный форум «Неделя горняка».
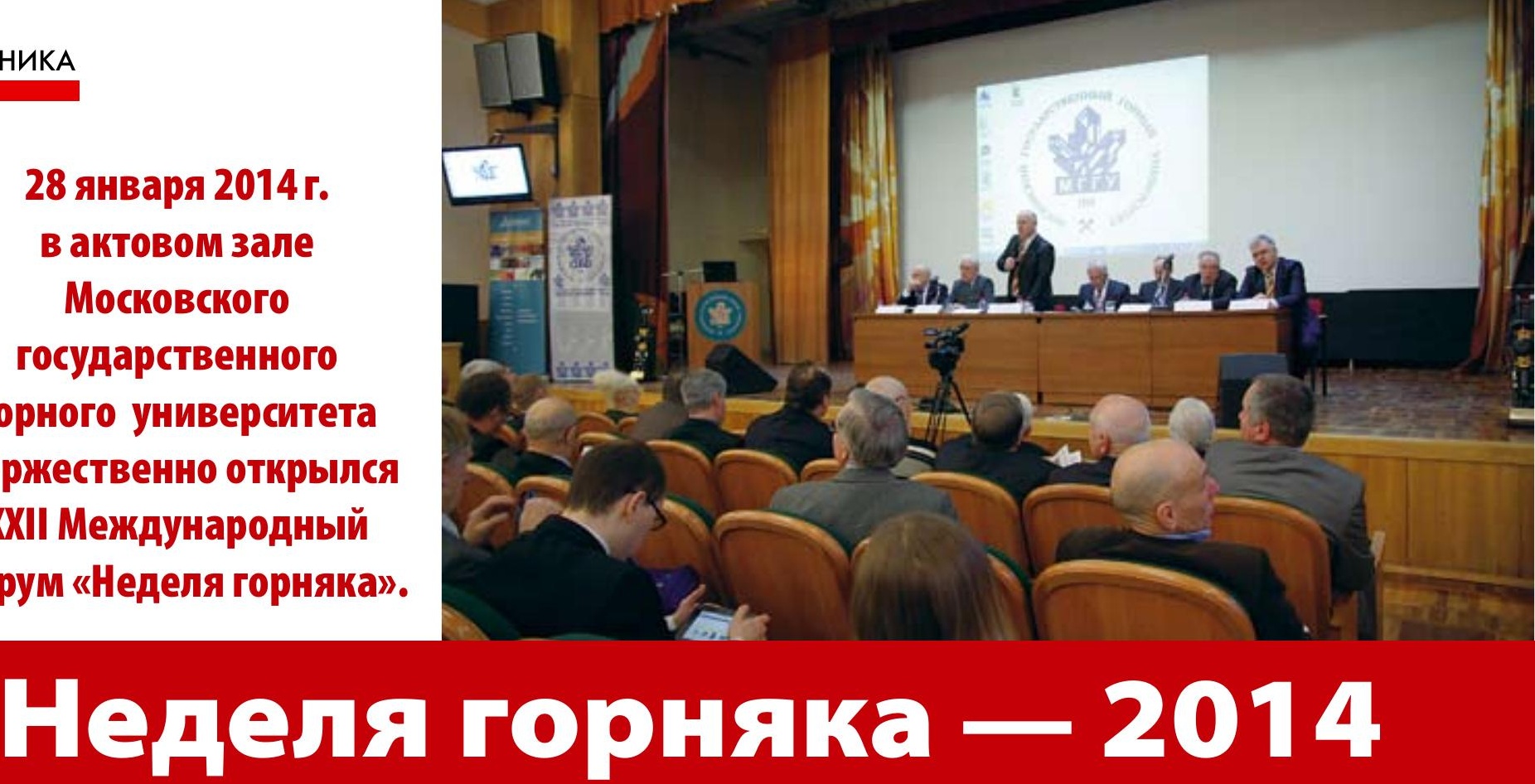

В Московском государственном горном университете в период с 27 по 31 января 2014 г. прошла XXII «Неделя горняка - 2014», в рамках которой были проведены: международный научный симпозиум; торжественное заседание Ученого совета университета; заседание Совета Учебно-методического объединения вузов Российской Федерации по образованию в области горного дела; заседание Научного совета РАН по проблемам горных наук и Совета Научно-учебного центра фундаментальных и прикладных исследований в области горного дела (НУЦ) ИПКОН РАН и МГГУ; заседание Научного совета РАН по проблемам народно-хозяйственного использования взрывов.

XXII Международный научный симпозиум «Неделя горняка 2014» включал работу 28 семинаров, охватывающих фундаментальные и прикладные проблемы горнопромышленной геологии, геофизики, маркшейдерского дела и геометрии недр, геомеханики, разрушения горных пород, рудничной аэрогазодинамики, горной теплофизики, экономики природопользования, геоэкологии, геоинформатики, геотехнологии (подземной, открытой, строительной), горных машин, электротехнических систем и комплексов, финансов горного производства.

В рамках работы данного международного Форума успешно прошли шесть круглых столов:

— «Специальные способы в городском подземном строительстве»;

— «Молодежный форум лидеров горного дела», «Использование отходов горной промышленности в производстве пеностекла и пеноматериалов»;

— «Повышение качественно-количественных показателей работы горно-перерабатывающих предприятий»;

— круглый стол, посвященный обсуждению «Инструкции по осуществлению мониторинга гео-, газодинамического состояния массива горных пород, прогноза горныхударов, внезапных выбросов угля (породы) и газа при отработке угольных месторождений»;

— круглый стол журнала «Глюкауф».

Среди гостей МГГУ присутствовали: ведущие специалисты в области горного дела, академики и члены-корреспонденты РАН, НАН Украины и НАН Республики Казахстан, представители министерств и ведомств, руководители горных вузов России и зарубежных стран, представители крупнейших российских и зарубежных горнодобывающих и горно-перерабатывающих компаний и многие другие специалисты, посвятившие себя развитию горного дела. 
Открываяпленарноезаседание, исполняющий обязанности ректора МГГУ профессор Вадим Леонидович Петров сообщил, что в форуме принимают участие представители 17 стран и республик, в том числе Германии, Румынии, Польши, Боснии и Герцеговины, Монголии, КНР, Вьетнама, Австралии, Египта, Мьянмы, Эстонии, Украины, Казахстана, Узбекистана, Таджикистана, Беларуси, Молдовы. Более

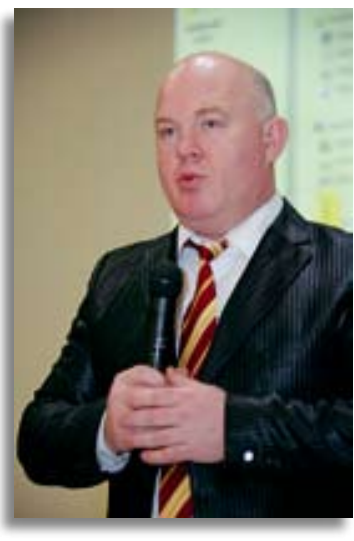
600 сторонних делегатов из 300 организаций и вузов, среди которых присутствовали ведущие ученые отрасли. В рамках работы 28 семинаров по основным направлениям развития горного дела и шести круглых столов было заявлено более 1150 докладов.

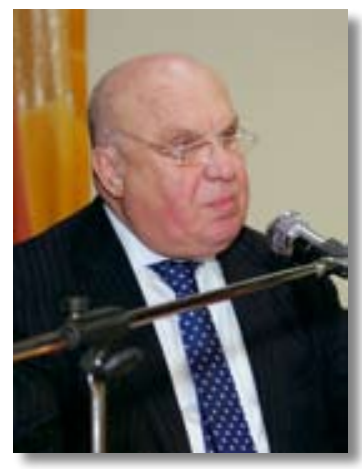

С приветственным словом выступили: академик РАН, президент «Академии горных наук», директор Государственного геологического музея им. В.И. Вернадского Ю.Н. Малышев, который констатировал сложность текущего периода развития горногопроизводства и горной науки. На примере угольной отрасли он продемонстрировал, что эффект от результатов проведенной в 1990-хгг. реструктуризации сегодня уже недостаточен, поэтому необходимо проводить «второй этап реструктуризации», в ходе которого нужно серьезно пересмотреть нормативные документы, привести в соответствие с требованиями времени не только подготовку горных инженеров, но и создать специальные колледжи для работников среднего звена горной промышленности. Академик РАН привел целый ряд дорогих и крупных проектов модернизации, осуществленных российскими угольными компаниями, однако этого недостаточно для успехов на мировом рынке.

В качестве примера разумной государственной политики академик РАН Ю.Н. Малышев привел Китай, горное машиностроение которого занимает сейчас «самые передовые позиции в мире», и российские горняки вынуждены закупать там необходимое оборудование.

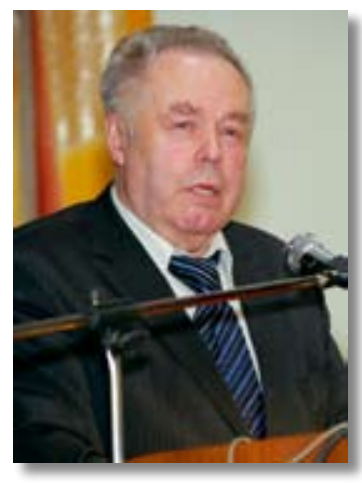

В своем выступлении председатель Союза старателей России Виктор Таракановский продолжил эту тему и отметил, что когда-то далеко отстававший от СССР по добыче золота, и тем более по производству горного оборудования, Китай в настоящее время вышел на первое место в мире по добыче и стал основным производителем оборудования для золотодобычи. В.И. Тарака- новский напомнил, что ранее крупные драги, например, производились на Иркутском заводе тяжелого машиностроения, территория которого теперь занята барахолкой. Он также остановился и на острой проблеме нехватки специалистов в отрасли. По его мнению, единственный выход в создавшейся ситуации - это законодательное закрепление обязанности выпускника отработать три года после окончания вуза по полученной специальности. Он пожелал, чтобы «Неделя горняка» продолжалась долгие годы, горная специальность в России не исчезала, а молодые горные специалисты остаются работать в горной отрасли.

\section{Исполнительный директор Горнорудного консультатив- ного совета (ГКС) Николай} Владимирович Матяш в своем приветствии выделил «Неделю горняка» как одно из самый значительных событий в жизни отрасли, когда наглядно демонстрируется потенциал российской и мировой горной науки, проводится глубокий анализ и вырабатываются новые практические рекомендации по совер-

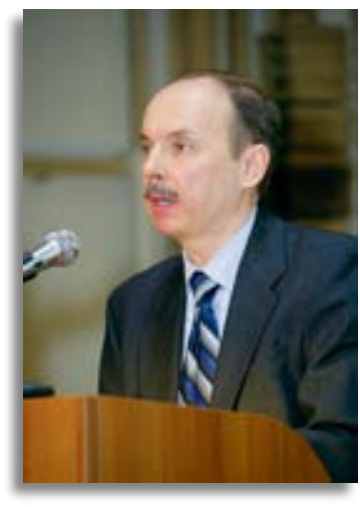
шенствованию производства, и высказался за дальнейшее развитие сотрудничества между МГГУ и ГКС. Форум имеет высокий авторитет и является открытой трибуной, где не только обсуждаются острые проблемы горнопромышленной отрасли, но и предлагаются действенные меры, направленные на их эффективное решение. От имени ГСК всем участникам Форума Николай Владимирович Матяш пожелал творческих успехов и плодотворного сотрудничества.

Первый вице-президент Российского геологического общества Евгений Гатович Фаррахов от имени президента РОСГЕО Виктора Петровича Орлова и всех российских геологов поздравил участников XXII Недели горняка с началом её работы и пожелал всем крепкого горного, геологического здоровья и новых творческих достижений.

С пленарными докладами выступили: член-корреспондент РАН Л.А. Пучков; академик РАН, директор ГоИ КНЦ РАН Н.Н. Мельников; доктор техн. наук, профессор, заведующий кафедрой МГГУ С.В. Сластунов; доктор техн. наук, профессор, заместитель директора ФГБУН ИПКОН РАНС.Д. Викторов; профессор технического университета «Фрайбергской горной академии» К. Дребенштедт.

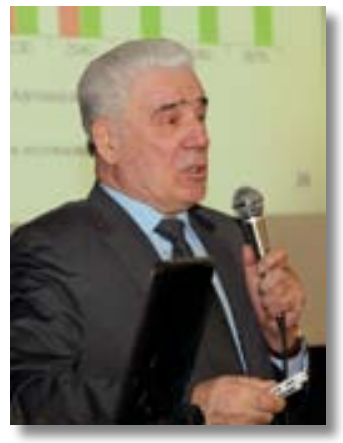

Член-корреспондент РАН Л.А.Пучков в своем докладе «Динамика минерально-энергетического потребления и развитие мировой экономики» представил результаты стратегического анализа глобального минеральноэнергетического потребления (МЭП), показывающего, что в мире общий рост потребления угля, 
нефти, газа и урана сопровождается стохастическими отклонениями от некоторого базового уровня, который фиксирует в каждый момент времени минимальное значение МЭП, и эти минимальные значения обладают фундаментальной устойчивостью и находятся на линии, отражающей прямо пропорциональную зависимость МЭП от численности населения планеты. Выполнен анализ установленных закономерностей демографического развития человечества Земли и взаимодействия этой глобальной системы с системой минерально-энергетического потребления в мире. Теоретический анализ полученных результатов с использованием методов теории катастроф позволил сформулировать методологию прогноза минерально-энергетического потребления, позволяющую более достоверно, чем это делают экономисты, прогнозировать развитие мировой экономики и обеспечить её устойчивое развитие.

\section{Академик Н.Н. Мельников в} докладе «Экологическая стратегия развития горнодобывающей отрасли» отметил, что осознание глобального характера экологических проблем, вызванных масштабами потребления ресурсов, негативного воздействия на природную среду, и определило стратегию развития отрасли, заключающуюся в повышении эффективности добычи и переработки мине-

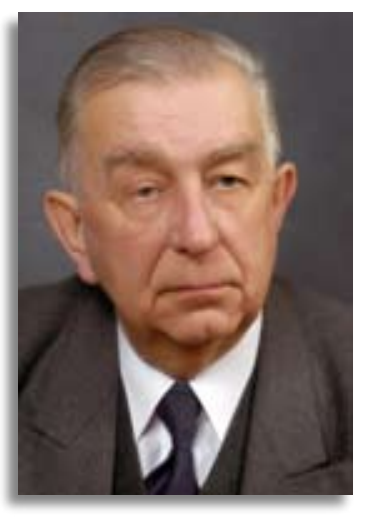
рального сырья при снижении техногенной нагрузки на природную среду. Для реализации экологической стратегии (в условиях карьера) необходимо достичь уменьшения объемов вскрыши при повышении эффективности и безопасности, уменьшения отходов производства за счет повышении комплексности и полноты извлечения полезных ископаемых, уменьшения складированных отходов за счет разработки техногенных месторождений, уменьшения объемов промышленных вод, сбрасываемых в водоемы, повышения извлечения самого полезного ископаемого за счет модернизации оборудования, и, наконец обеспечить восстановление природных экосистем. Для оценки состояния атмосферы в карьере создана система комплексного автоматизированного мониторинга и программно-аппаратный комплекс, которые позволяют контролировать ее работу в любом месте. Реализация этой экологической стратегии

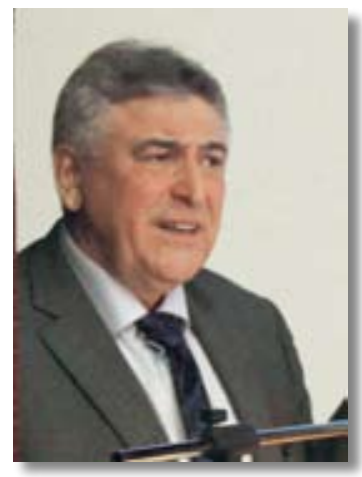
на предприятиях подтвердила обоснованность предлагаемых решений, что можно видеть на примере Кольского горнопромышленного комплекса.

Доклад профессора С. В. Сластунова был посвящен 85-летию со дня рождения горного инженера Николая Васильевича Ножкина (1928-1995 гг.), профессора кафедры «Аэрология и охрана труда» Московского горного института, доктора технических наук, выдающегося русского ученого-горняка, основателя научного направления по заблаговременной дегазации угольных месторождений. Особое внимание в докладе было уделено развитию идей Н. В. Ножкина на современном этапе развития горной науки, его ученикам и коллегам.

Профессор С.Д. Викторов в докладе «Проблемы разрушения горных пород при добыче твердыхполезных ископаемых» отметил, что фактически все при добыче полезных ископаемых так или иначе связано с разрушением, дроблением на различных масштабных уровнях, но самые масштабные - массовые взрывы на карьерах, когда взрывают иногда тысячи тонн ВВ. Существенный прогресс в развитии открытых горных работ на крупных предприятиях возможен при переходе на крупномасштабную взрывную подготовку горного массива, а управление параметрами разрушающего импульса возможно за счёт применения специальных конструкций и схем расположения зарядов на уступах и способов их взрывания. В докладе показаны новые возможности применения современных инструментальных методов исследования процессов горного производства. Впервые экспериментально установлено явление эмиссии микро - и наночастиц при нагружении горных пород и строительных материалов. Полученные закономерности послужат основой разработки принципиально новых инструментальных методов прогноза горных ударов, внезапных выбросов при ведении горных работ на больших глубинах и метанообильных шахтах. Результаты исследований могут быть использованы для развития представлений о процессах деформирования и разрушения горных пород и послужить основой для разработки новых экспериментальных методов исследования этих процессов.

Профессор технического университета «Фрайбергской горной академии", почетный доктор МГГУ К. Дребенштедm выступил с докладом на тему «Перспективы применения циклично-поточной технологии в мировой горной промышленности».

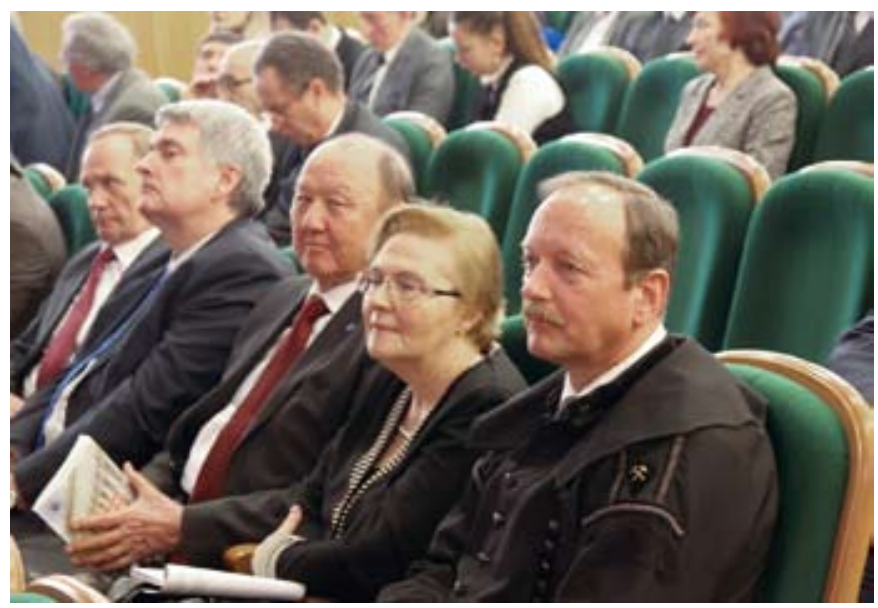




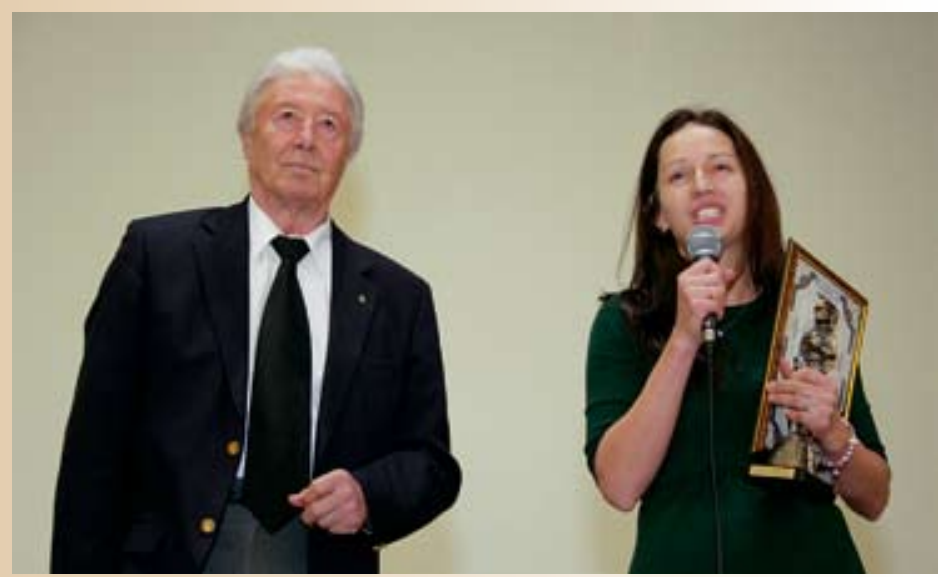

Компания Sandvik Mining стала обладателем премии «Золотой горняк - 2013»

Sandvik - это группа высокотехнологичных машиностроительных компаний, занимающая лидирующее положение в мире в производстве инструмента для металлообработки, разработке технологий изготовления новейших материалов, а также оборудования и инструмента для горных работ и строительства. Sandvik работает более чем в 130 странах.

Sandvik Mining - одно из бизнес-подразделений группы Sandvik, занимающее третью часть всей группы компаний. Подразделение является одним из мировых лидеров в предоставлении инжиниринговых решений и производстве оборудования в области геологоразведки, горной промышленности и транспортировки сыпучих материалов. Оборудование и инструмент Sandvik применяются как для открытых, так и для подземных горных работ на всех этапах производственного процесса в горнодобывающей промышленности.

Подразделение компании Sandvik Mining, работающее на территории СНГ, занимается поставкой и сервисом оборудования, а также продажей запасных частей для горнодобывающей отрасли.
На торжественном заседании Ученого совета университета профессору Казахского национального технического университета им. К. И. Сатпаева Ракишеву Баяну Ракишевичу был вручен диплом Почетного доктора МГгу.

В заседании Совета Учебно-методического объединения вузов Российской Федерации по образованию в области горного дела (УМО) участвовали 74 человека, представляющих 25 вузов Российской Федерации и 7 их филиалов, ведущих подготовку горных инженеров, Российскую академию естественных наук, Некоммерческое партнёрство «Горнопромышленники России», ООО «Макромайн РУС» (разработка программного обеспечения для геологоразведки и горной промышленности), 2 вуза стран СНГ (Казахстан, Узбекистан). На заседании были рассмотрены такие основные вопросы, как: Федеральные государственные образовательные

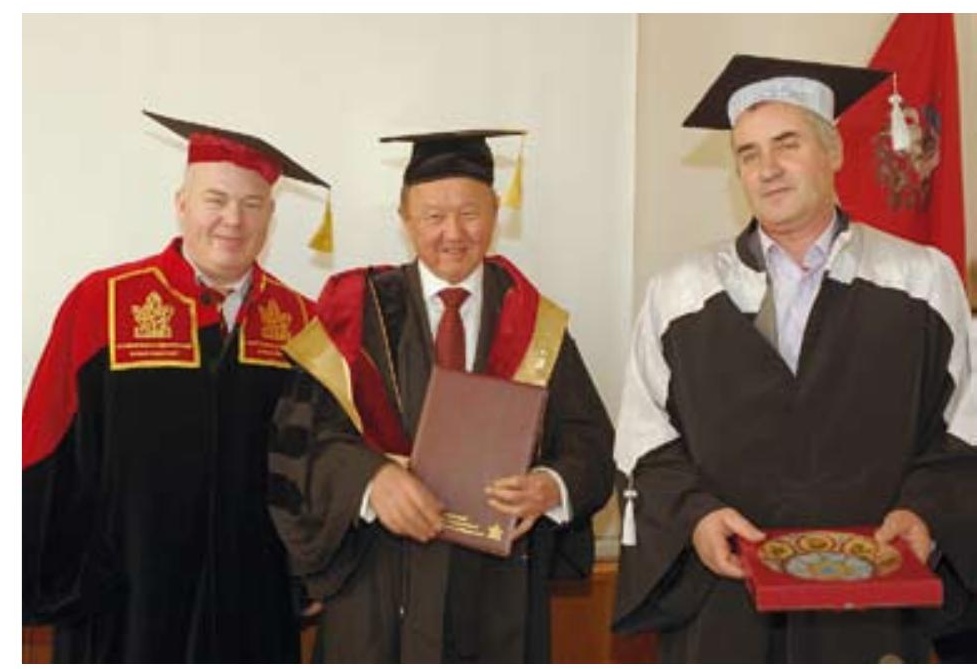

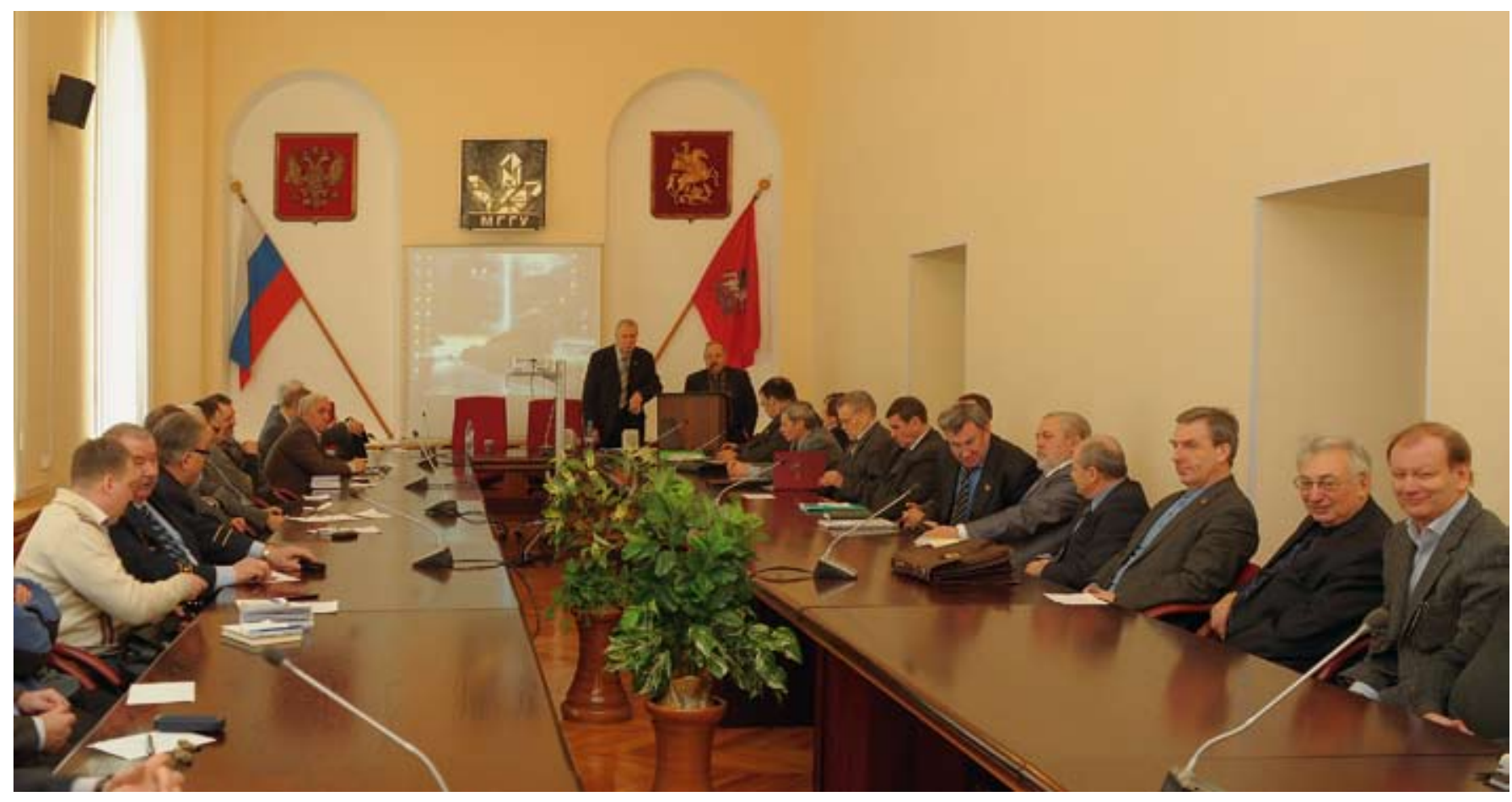




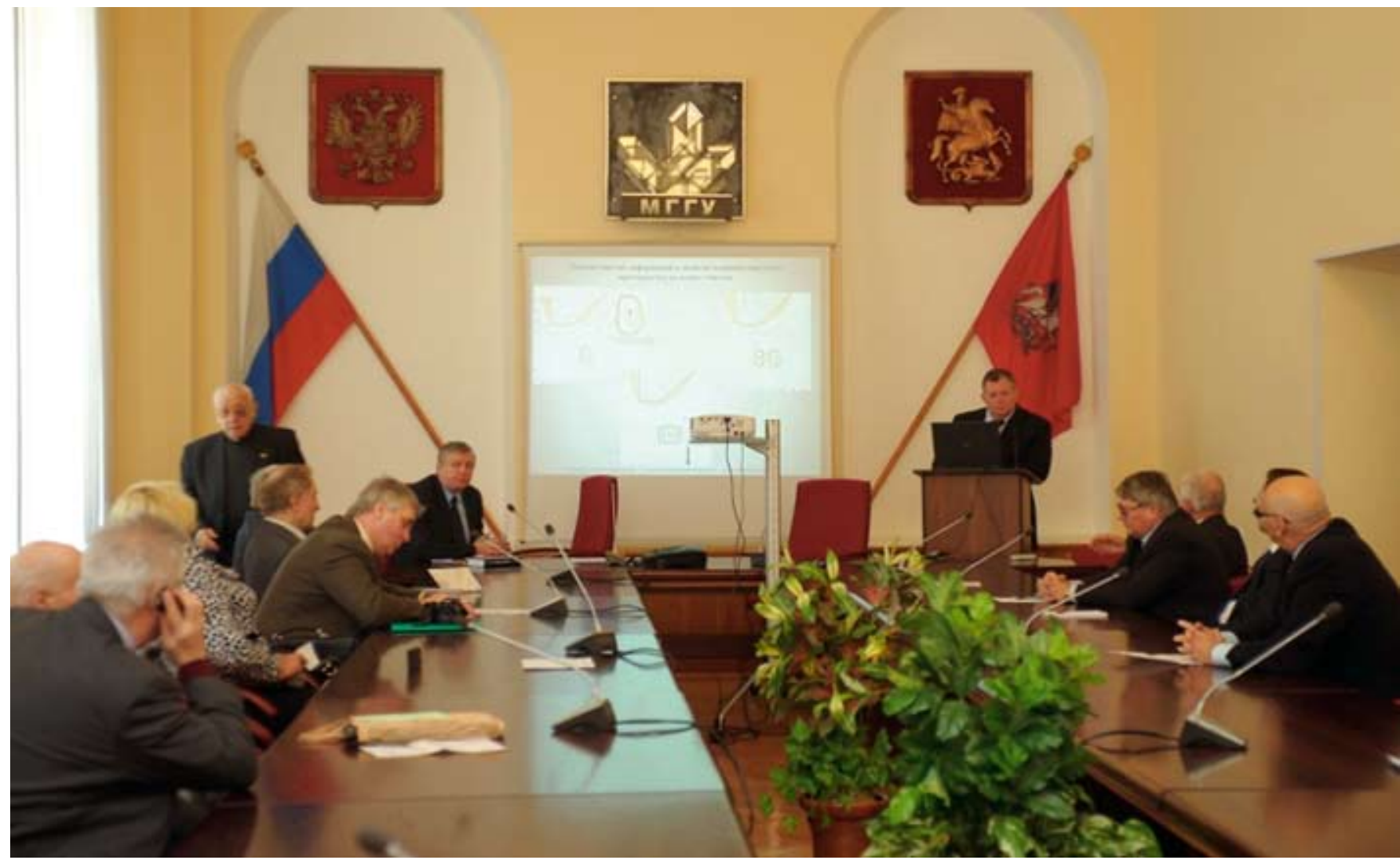

стандарты высшего образования по горным специальностям (новые редакции) в условиях введения в действие Федерального закона «Об образовании в Российской Федерации» (29.12.2012 от № 273-Ф3); экологизация учебных программ подготовки специалистов технического профиля; проект «Мобильная библиотека» для горных и технических вузов.

На заседании Научного совета РАН по проблеме «Народнохозяйственное использование взрыва» присутствовало 38 ведущих ученых и специалистов в области теории и практики взрывных работ из 20 организаций, предприятий и научно-исследовательских институтов. Председатель Совета, академик РАН В. В. Адушкин представил доклад по анализу сейсмического воздействия промышленных взрывов на территории Европейской части России.

С докладом «Изменения законодательства в области взрывного дела» выступил начальник отдела Ростехнадзора А.В. Макаров. На заседании была рассмотрена и обсуждена концепция сертификации промышленных взрывчатых веществ в Российской Федерации, предложенная генеральным директором $3 \mathrm{AO}$ «Взрывиспытание», доктором техн. наук, профессором А.С. Державецом.

С докладом «Состояние БВР на угольных шахтах России и перспективы развития» выступил директор по науке и перспективам развития Межведомственной комиссии по взрывному делу при АГН доктор техн. наук А.В. Джигрин. Генеральным директором ОАО «ЛОГИС», канд. техн. наук Н. П. Семейкиным и доктором техн. наук, профессором кафедры «Взрывное дело» МГГУ Б. В. Эквистом была представлена информация о новых современных методах и аппаратуре, разработанных в РФ и предназначенных для обнаружения взрывчатых веществ. По результатам обсуждения от имени Научного Совета РАН по проблеме «Народнохозяйственного использования взрыва» подготовлено письмо в Правительство РФ с предложениями по реализации концепции сертификации промышленных ВВ в Российской Федерации в рамках Таможенного союза.

На совместном заседании Научного совета РАН по проблемам горных наук и Совета Научно-учебного центра фундаментальных и прикладных исследований в области горного дела (НУЦ) ИПКОН РАН и МГГУ был сделан доклад докт. техн. наук, ведущего научного сотрудника ИПКОН РАН В.А. Еременко на тему «Комплекс геотехнологических решений при освоении месторождений твердых полезных ископаемых на больших глубинах в структурно нарушенных и удароопасных массивах горных пород».

\section{Обмен опытом между компаниями ТЭК и горнодобывающего сектора по вопросам привлечения и развития персонала}

Организованный НП «Молодежный форум лидеров горного дела» совместно с Благотворительным фондом «Надежная смена» круглый стол на тему «Обмен опытом между компаниями ТЭК и горнодобывающего сектора по вопросам привлечения и развития персонала» был посвящен изучению опыта работы крупнейших российских энергокомпаний с молодежью. В ходе мероприятия в качестве спикеров выступили представители ведущих российских энергокомпаний: Елена Аксенова (ОАО «РусГидро»), Дарья Леготкина (ООО «Лукойл-Пермь»), Николай Цветков (ООО «Газпром энергохолдинг»), Алла Шутенко (ОАО «Системный оператор») и Андрей Гофман (БФ «Надежная смена»). Выступающие подробно осветили механизмы, используемые 
электроэнергетическими и нефтегазовыми компаниями для привлечения и удержания молодых квалифицированных специалистов по цепочке школавуз-предприятие, а также мотивации молодых специалистов к выстраиванию длительных трудовых отношений и профессиональной карьеры в ТЭК. От горняков в дискуссии приняли участие представители ОАО «СУЭК», ЕВРАЗ, ООО «Руссдрагмет», ОАО ХК «СДСУголь», ОАО МХК «ЕвроХим», а также компаний MICROMINE и ITP, Московского института стали и сплавов и Ивановского государственного политехнического университета. В ходе дискуссии участниками мероприятия, в частности, было предложено обратиться с инициативой в Министерство образования и науки по увеличению продолжительности практик до 3-4 месяцев, а также внедрения системы дуального образования. Последнее является достаточно актуальным для ряда регионов, где студенты обучаются в непосредственной близости от мест будущей работы. Такая система обучения, по мнению участников, весьма успешно зарекомендовала себя за рубежом.

\section{Новые возможности}

\section{в обогащении шламов}

В рамках семинара по обогащению полезных ископаемых «Физические и химические методы переработки минерального сырья» на «Неделе горняка» был заявлен доклад «Оптимизация схем обогащения угольных шламов в спиральных сепараторах».

Представленный инженером-техно-
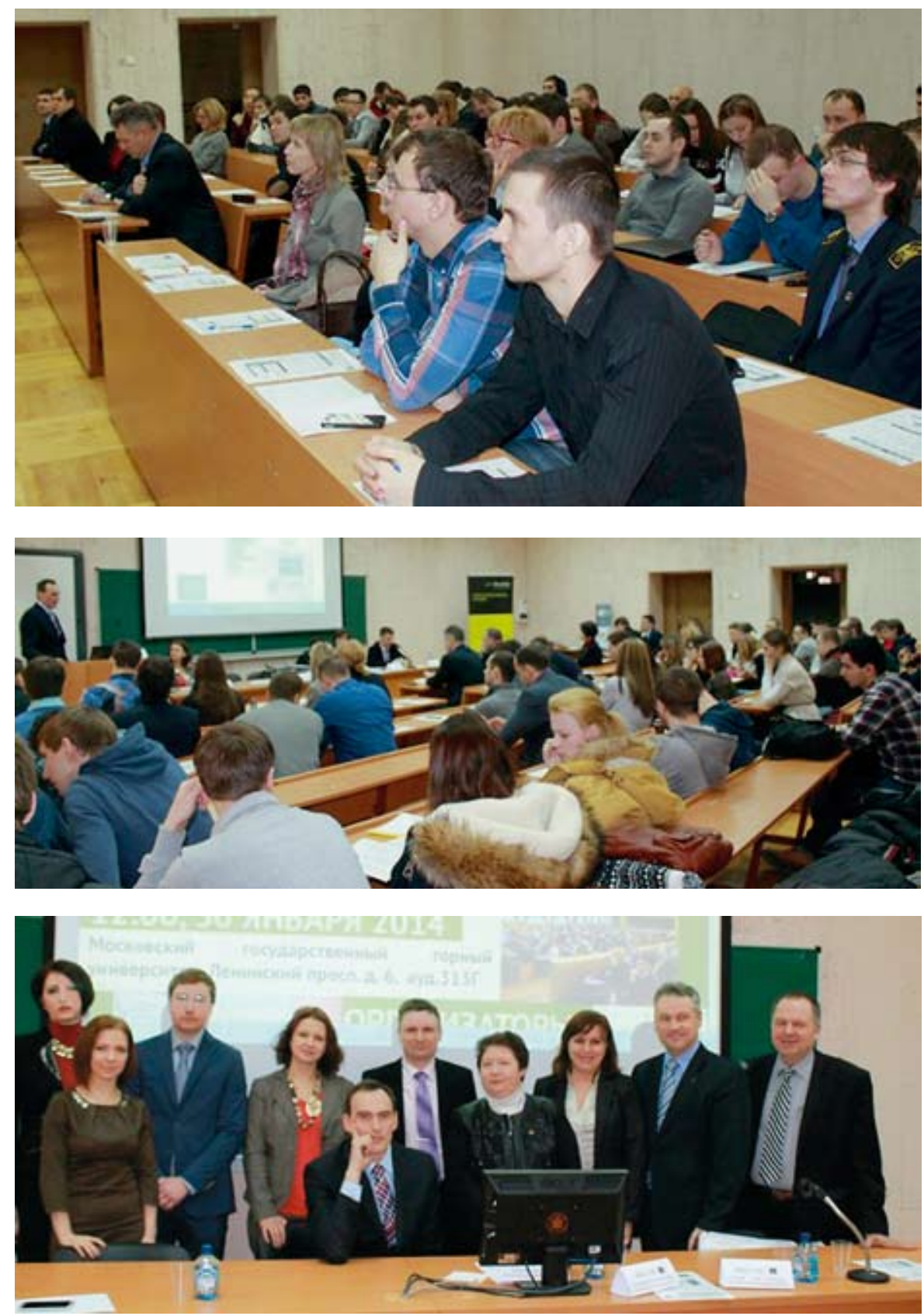
логом ООО «Коралайна Инжиниринг» (СЕТСО) Пикаловым М.Ф. доклад содержал подробное описание разработанных и закрепленных патентами на изобретения схем обогащения шламов в спиральных сепараторах, основным отличием которых от традиционных схем является применение одной стадии гидроклассификации исходного шлама по граничному зерну 0,04 мм.

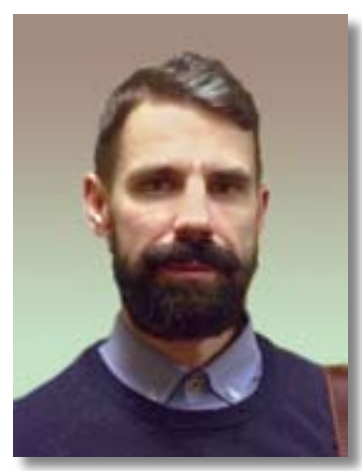

По расчетам авторов, новые схемы позволяют обогащать шлам широким классом, уменьшая тем самым потери угля с отходами, снижают переизмельчение шлама за счет исключения дополнительных перекачек угольной пульпы и в 1,5 раза уменьшают капитальные и эксплуатационные затраты по сравнению с традиционными схемами обогащения.

Перед проведением Форума были изданы: сборник трудов международного научного симпозиума «Неделя горняка -2014 » (пленарные доклады и «ключевые» доклады семинаров), сборник научных трудов семинара "Современные технологии в горном машиностроении", сборник трудов, посвященный памяти профессора Н.В. Ножкина, «Современные проблемы шахтного метана". В работе семинаров и круглых столов активное участие принимали магистры, аспиранты, студенты, молодые ученые и инженеры из различных вузов и организаций. 


\section{РЕШЕНИЯ ДЛЯ ПРОМЫШЛЕННОСТИ И ТРАНСПОРТА}
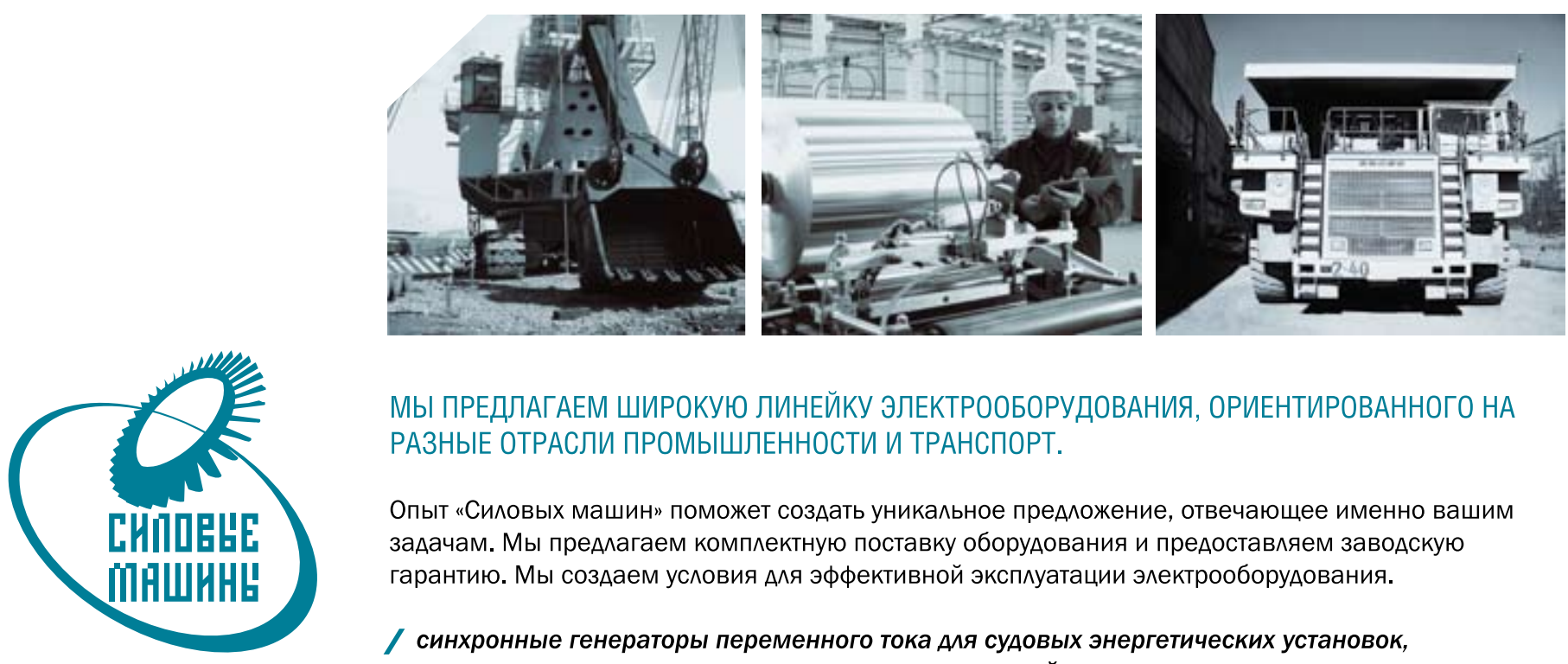

МЫ ПРЕДЛАГАЕМ ШИРОКУЮ ЛИНЕЙКУ ЭЛЕКТРООБОРУДОВАНИЯ, ОРИЕНТИРОВАННОГО НА РАЗНЫЕ ОТРАСЛИ ПРОМЫШЛЕННОСТИ И ТРАНСПОРТ.

Опыт “Силовых машин” поможет создать уникальное предложение, отвечающее именно вашим задачам. Мы преАлагаем комплектную поставку оборудования и предоставляем заводскую гарантию. Мы создаем условия Аля эффективной эксплуатации электрооборудования.

/ синхронные генераторы переменного тока Аля судовых энергетических установок, стационарных и передвижных дизель-электростанций, а также ветроэнергетических установок;

/ электродвигатели переменного и постоянного тока;

/ электропривод и комплектные устройства переменного и постоянного тока;

/ тяговое электрооборудование Аля городского и железнодорожного электротранспорта, а также Аля карьерных самосвалов БелАЗ. 


\section{Второй Всероссийский чемпионат}

\section{по решению кейсов в области горного дела успешно стартовал в НМСУ «Горный»}

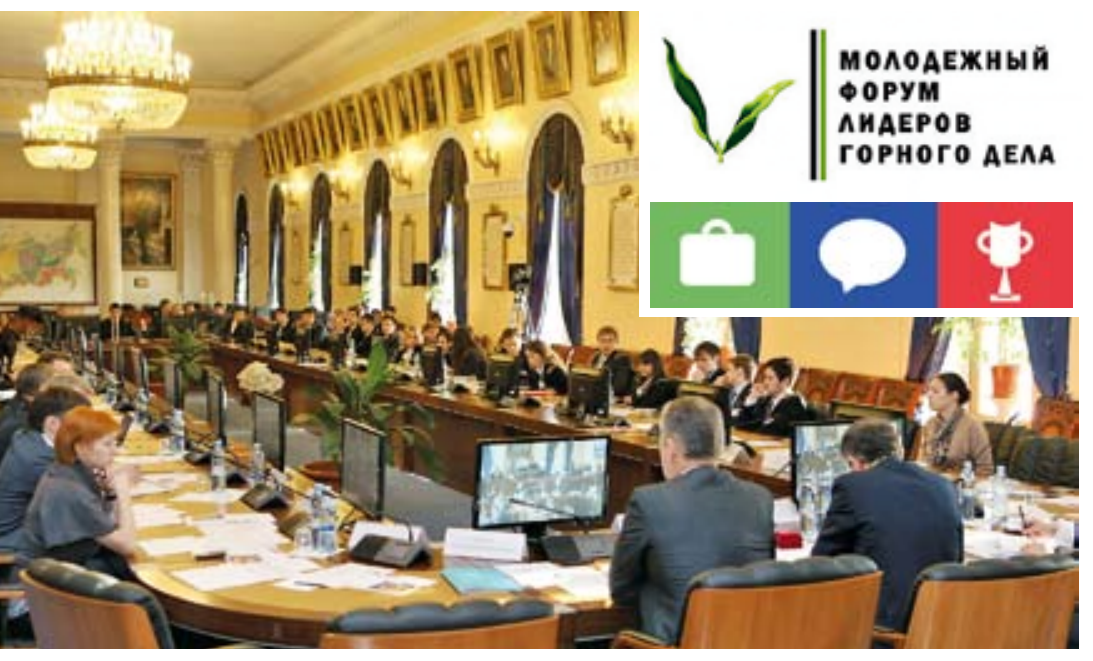

25 февраля в Санкт-Петербурге, в Национальном минерально-сырьевом университете «Горный» состоялось торжественное открытие и первый отборочный этап Второго Всероссийского чемпионата по решению кейсов в области горного дела. В мероприятии приняли участие студенты, руководство и профессорско-преподавательский состав НМСУ «Горный», а также руководители и представители компаний ОАО «СУЭК», ОАО «Апатит» (холдинг «ФосАгро»), OAO «Еврохим», IMC Montan и Комитета по молодежной политике и взаимодействию с общественными организациями Администрации Санкт-Петербурга.
В задачу участников Чемпионата по решению кейсов входит теоретическое устранение конкретной производственно-финансовой проблемы, стоящей перед реальным предприятием. Победителем становится та команда, которая, по мнению экспертов, предложит наиболее удачный вариант, основываясь на теоретических знанияхи профессиональном опыте участников, их умении делать технико-экономические расчеты и логически мыслить.

Этап в НМСУ «Горный» был посвящен памяти начальника сводного информационно-аналитического отдела Департамента угольной и торфяной промышленности Минэнерго России Владимира Александровича Воронкова. С самого момента основания Молодежного форума лидеров горного дела он оказывал ему всестороннее содействие и принимал активное участие в его мероприятиях в качестве эксперта.

Всего в проекте примут участие более 1000 лучиих студентов и аспирантов из 18 высших учебных заведений, которые представляют 17 городов России. Кроме того, в нынешнем году к проекту присоединились зарубежные партнеры - три высиих техническихучебныхзаведения Казахстана. Таким образом, чемпионат пройдет в 21 высшем учебном заведении в 20 городах России и Казахстана!

\begin{tabular}{|l|c|}
\hline \multicolumn{1}{|c|}{ График Чемпионата - 2014 } & 25.02 .2014 \\
\hline Национальный минерально-сырьевой университет «Горный» (г. Санкт-Петербург) & 27.02 .2014 \\
\hline Северо-Восточный государственный университет (г. Магадан) & 03.03 .2014 \\
\hline Дальневосточный федеральный университет (г. Владивосток) & 12.03 .2014 \\
\hline Северо-Восточный федеральный университет им. М.К. Аммосова (г. Якутск) & 14.03 .2014 \\
\hline Карагандинский государственный технический университет (г. Караганда) & 17.03 .2014 \\
\hline Казахский национальный технический университет им. К.И. Сатпаева (г. Алматы) & 19.03 .2014 \\
\hline Восточно-Казахстанский государственный технический университет им. Д. Серикбаева & 25.03 .2014 \\
\hline (г. Усть-Каменогорск) & 26.03 .2014 \\
\hline Иркутский государственный технический университет (г. Иркутск) & 28.03 .2014 \\
\hline Забайкальский государственный университет (г. Чита) & 31.03 .2014 \\
\hline Московский государственный горный университет (г. Москва) & 01.04 .2014 \\
\hline Сибирский государственный индустриальный университет (г. Новокузнецк) & 03.04 .2014 \\
\hline Кузбасский государственный технологический университет (г. Кемерово) & 08.04 .2014 \\
\hline Российский государственный геологоразведочный университет им. Серго Орджоникидзе \\
\hline (г. Москва)
\end{tabular}




\title{
Финал Чемпионата пройдет на площадке
}

Государственного геологического музея им.В.И. Вернадского, Москва, 30 мая 2014 г.

\begin{abstract}
Чемпионат — крупнейший молодежный образовательный проект горнодобывающего сектора России, проходящий в формате бизнес-кейсов и направленный на выявление и поддержку активных, талантливых и целеустремленных студентов и аспирантов горного дела ведущих вузов России, осуществляющих подготовку специалистов горного профиля.

Организатором мероприятия является НП «Молодежный форум лидеров горного дела» при поддержке фонда поддержки культурных и образовательных инициатив «Новый диалог», Региональной общественной организации «Институт проблем гражданского общества», Минэнерго России, Минприроды России и Росмолодежи. Генеральными партнерами чемпионата выступают ОАО «СУЭК», ЕВРАЗ, ОАО «ОУК «Южкузбассуголь». Партнерами отдельных этапов Чемпионата являются ОАО «ЮГК», ОАО «Апатит», ОАО МХК «Еврохим», ОАО «Высочайший», ООО «Руссдрагмет», MICROMINE, группа IMC Montan, OAO XK «СДС-Уголь» и ОАО «Полиметалл». При реализации проекта также используются средства государственной поддержки

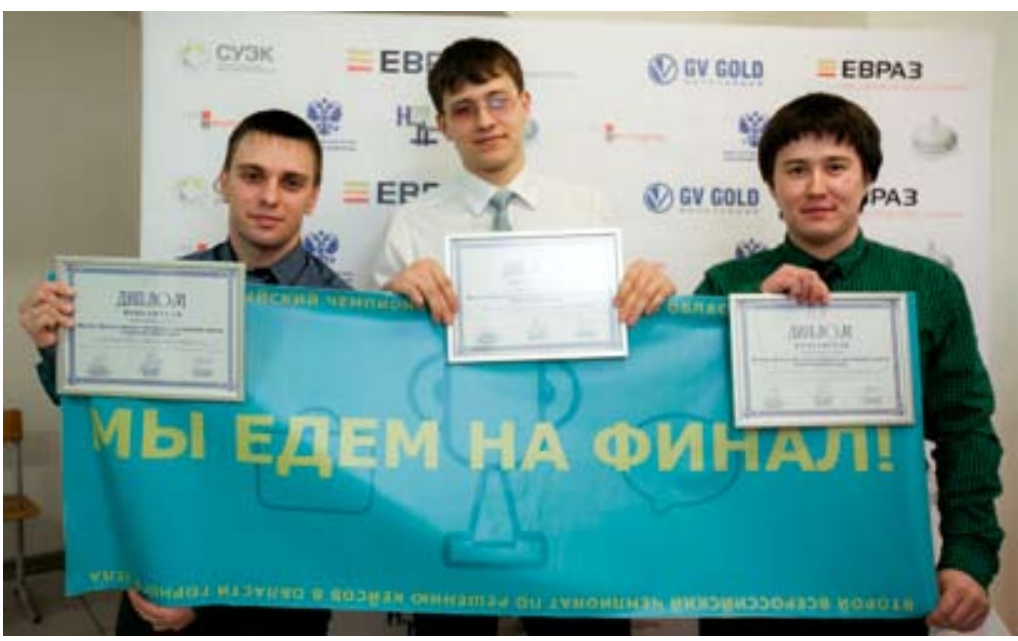

\footnotetext{
Подробнее узнать о чемпионате можно на сайте http://vseros. yminer. ru

Контакты организаторов: Власова Алена Юрьевна, тел.: +7 (985) 800-27-35;

e-mail: vlassovaalena@yminer.ru
}

\section{При поддержке СУЭК в Санкт-Петербурге стартовал Второй Всероссийский чемпионат по решению кейсов в области горного дела}

При поддержке СУЭК в Национальном минерально-сырьевом университете «Горный» (НМСУ «Горный», Санкт-Петербург) состоялось открытие и первый отборочный этап второго Всероссийского чемпионата по решению кейсов в области горного дела среди студентов и аспирантов.

Чемпионат - молодежный образовательный проект горнодобывающего сектора России, проходящий в формате бизнес-кейсов и направленный на выявление и поддержку активных, талантливых и целеустремленных студентов и аспирантов ведущих вузов России, осуществляющих подготовку специалистов горного профиля.

В ходе мероприятия 12 команд Горного университета презентовали решения кейса по модернизации оборудования и повышению эффективности технологического процесса на предприятиях угледобывающего холдинга. Цель - снижение себестоимости добычи угля и повышение производительности труда в условиях кризиса.

Победителем стала команда «Горная сборная», которая будет представлять Горный университет в финале кейс-соревнования в конце мая этого года в Москве.

Всего в проекте примут участие более 1000 лучших студентов и аспирантов из 21 высшего учебного заведения, которые представляют три города Казахстана и 17 городов России. В этом году к проекту присоединились зарубежные партнеры - три высших технических учебных заведения Казахстана. 


\section{Модульный тип конструкции — современный подход к проектированию обогатительных фабрик}

\begin{abstract}
Диктуемые реалиями рынка новые требования к работе перерабатывающих предприятий не всегда позволяют реализовать желания заказчиков с помощью классических подходов к проектированию. Поиски новых, более эффективных, методов проектирования обогатительных фабрик ведутся непрерывно. Модульный тип конструкции фабрики - один из современных способов решения задачи универсальности и низкой стоимости строительства углеобогатительных предприятий.

Ключевые слова: проектирование углеобогатительных фабрик, модульная строительная конструкция, этажерка.
\end{abstract}

Контактная информация:

e-mail:Grishin@cetco.ru

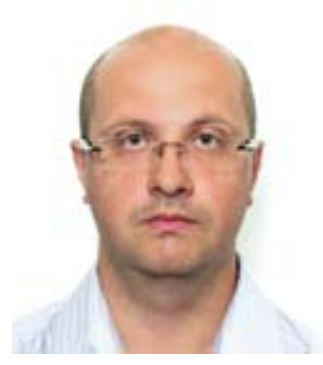

\section{гРИшИн}

Игорь Александрович

Руководитель группы

технологического

проектирования,

угольный департамент

«Коралайна Инжиниринг»

(CETCO)

фабрики, опорные конструкции которых под оборудование завязаны с несущими конструкциями главного корпуса в одну систему. Второй тип - это фабрики, в которых опорные элементы под оборудование отделены от конструкций здания, но при этом продолжают оставаться связанными между собой в единую сложную структуру.

В первом типе фабрик внутреннее пространство организовано так, что рабочие площадки опираются как на внутренние колонны, так и на колонны главного корпуса. При таком подходе часть оборудования скрывается вышерасположенными производственными отметками, которые примыкают к колоннам главного корпуса. В результате внутреннее пространство обогатительной фабрики делится на две зоны:среднюю и боковую.

Подавляющее большинство обогатительных фабрик, построенных еще во времена СССР, было спроектировано под сырье, поступающее из расположенных рядом шахт или разрезов. Сырьевая база таких фабрик долго оставалась неизменной, что позволяло использовать выбранную технологию обогащения без внесения изменений в технологический процесс на протяжении длительного времени.

Рыночные условия изменили эту практику. Для улучшения экономических показателей работы угольных предприятий их владельцы стремятся обогащать угли разных месторождений на одной фабрике. Кроме того, на рынке появилось заметное количество игроков, которые не имеют собственных источников сырья и покупают рядовой уголь у сторонних добывающих организаций. Результатом таких изменений стал рост спроса на фабрики, которые могут работать на разном сырье и при этом выпускать продукцию высокого качества.

Очень часто применение классических подходов к проектированию фабрик с различными схемами обогащения становится невозможным. В этом случае при проектировании необходимо использовать решения на базе модульного подхода. Сущность модульного подхода заключается в разделении общей схемы обогащения на отдельные участки - модули - которые не всегда прямо связаны друг с другом, что позволяет, в зависимости от необходимости, раздельно включать и выключать их из процесса. Данное решение позволяет менять в широких пределах схему и технологию обогащения. Также в этом случае гораздо проще проводить модернизацию фабрики изменяя старые, удаляя или добавляя новые модули. В России первой применять модульный подход к проектированию обогатительных фабрик стала компания «Коралайна Инжиниринг» - CETCO.

При классическом подходе к проектированию все обогатительные фабрики делятся на два типа. Первый тип - это
Средняя часть опирается на внутренние колонны и может иметь различную высоту. Это главная рабочая зона фабрики, где ставят основное, самое тяжелое оборудование. Обслуживание данной зоны осуществляется мостовым краном.

Боковая зона носит скорее вспомогательный характер. В ней может располагаться вспомогательное техническое оборудование и прочие элементы главного корпуса, не вовлеченные в основной технологический процесс, такие как технические помещения, системы вентиляции и отопления, помещения для обслуживающего персонала. Это вызвано тем, что для создания рабочей площадки в этой зоне необходимо связать с несущими конструкциями средние колонны и колонны главного корпуса. Таким образом, каждая последующая вышерасположенная отметка будет полностью перекрывать нижнюю. В результате, на эти площадки не будет доступа основного крана, а для нормальной эксплуатации расположенного на них оборудования потребуются дополнительные грузоподъемные механизмы, которые изза своих размеров не всегда имеют достаточную мощность, чтобы обслужить тяжелое оборудование.

Одним из главных недостатков данного подхода к проектированию обогатительных фабрик является перенос вибрационных и динамических нагрузок от оборудования на несущий каркас главного корпуса. Это происходит изза жесткой связи рабочих площадок с колоннами здания. Именно несущие балки площадок боковой зоны передают все нагрузки от средней рабочей части фабрики на колонны корпуса.

В настоящее время не существует методик точного расчета конструкций главного корпуса с учетом вибрационных и динамических воздействий от оборудования. Слишком сложной получается расчетная схема. Кроме того, большинство производителей не могут дать точных значений 
дополнительно возникающих вибрационных сил от работающего оборудования. Поэтому конструкторы, страхуясь от возможных рисков, либо «перезакладываются» в расчетах, увеличивая стоимость строительства фабрики, либо считают конструкции по строительным нормам и правилам, не учитывающим вибрационной составляющей. В итоге получается фабрика, корпус которой вибрирует. Трясется все - стены, кровля, рабочие площадки, лестницы. Амплитуда колебаний может достигать нескольких сантиметров. При этом прочностный расчет будет соответствовать нормам проектирования. Находиться внутри такой фабрики некомфортно и небезопасно.

Ко второму типу классического подхода к проектированию относятся фабрики, где опорные конструкции под оборудование отделены от колонн главного корпуса. Это решение исправляет основной недостаток первого типа - на каркас фабрики уже не влияют динамические и вибрационные нагрузки от оборудования. Примерами конструкции второго типа являются фабрики, построенные в России по проектам отечественных проектных институтов за последние 15 лет.

При проектировании углеобогатительных фабрик по такому принципу технологическое оборудование располагается на своих собственных опорных конструкциях, не имеющих связи с главным корпусом. В результате получаются две независимые системы, выполняющие разные функции. Первая система - это главный корпус здания, основная задача которого укрыть от атмосферного воздействия технологическое оборудование и обеспечить рабочую среду. Несущие конструкции здания рассчитываются только на внешние воздействия (ветер, снег и пр.), на нагрузки от инженерных систем и на нагрузки от грузоподъемного оборудования. Вторая система - технологическое оборудование со своими опорными конструкциями.

Достаточно часто указанный тип классического подхода к проектированию ошибочно называют «модульным». Его основным недостатком является единая внутренняя система опорных конструкций под оборудование. Именно на эту систему передаются все возможные нагрузки от практически всего технологического оборудования. В результате получается сложная и слабо поддающаяся модернизации конструкция с многочисленными связями и усилениями.

"Коралайна Инжиниринг» реализует в своих проектах новейший подход к проектированию обогатительных предприятий. Он лишен недостатков первого типа и дополняет положительные моменты второго типа классического подхода к проектированию фабрик.

Сущность подхода заключается в том, что мы дополнительно выделяем в технологической схеме отдельные независимые участки (модули), которые выполняют разные функции и по-разному воздействуют на опорные конструкции. Например, этапы классификации и дешламации на грохотах выполняются на отделенных от остального оборудования опорных конструкциях. Это позволяет выполнить данные рабочие площадки более массивными, с большим запасом прочности, сдополнительными связями и жесткими узлами. Такое решение необходимо для того, чтобы погасить большие вибрационные и динамические нагрузки от тяжелого оборудования внутри этой системы.

Остальное оборудование, не дающее значительных нагрузок, размещается на более легких конструкциях других

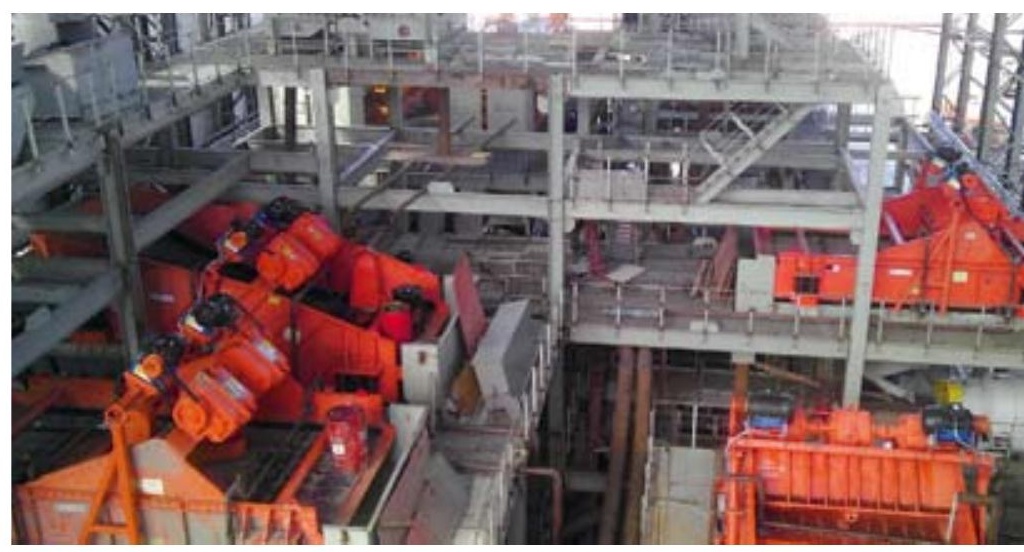

Этажерки модульного типа главного корпуса углеобогатительной фабрики «Эльгинская» (на этапе строительства)

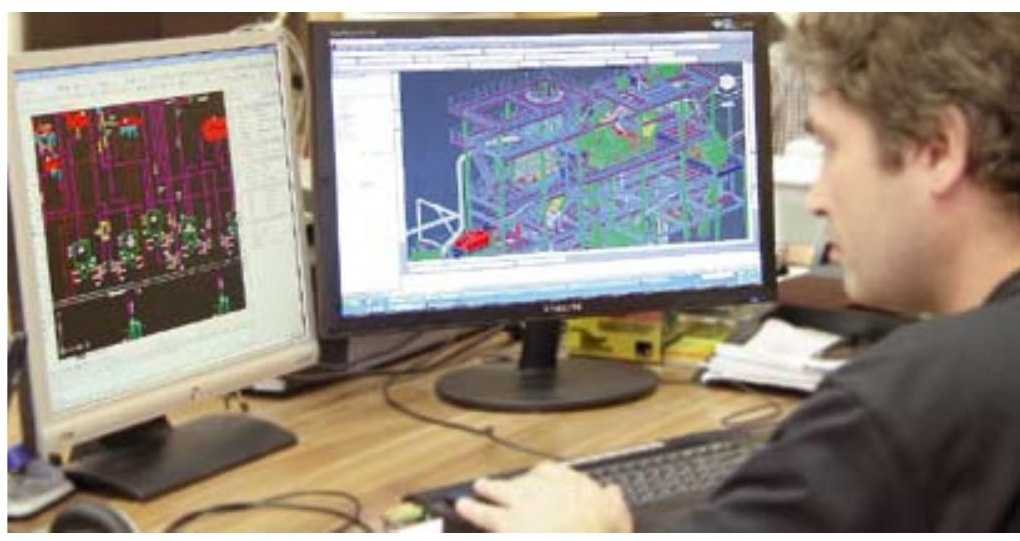

Интерфейс программы «Веntley» для проектирования этажерок главных корпусов фабрик в формате 3D

модулей, позволяя экономить металл и тем самым уменьшая капитальные затраты на строительство фабрики.

Кроме того, отдельные модули проще и дешевле модернизировать при реконструкции фабрик, ведь все работы по усилению конструкций или по изменению площадок можно проделать в пределах одного модуля, не вмешиваясь в устройство всей фабрики. Таким образом, мы получаем дополнительные возможности в деле настройки технологии фабрики под конкретные требования.

Внедрение новых технических и технологических решений, имеющих успешный опыт применения за рубежом, позволили «Коралайна Инжиниринг» занять на российском рынке ведущее место в области проектирования современных углеобогатительных фабрик. За более чем двадцатилетний период работы компании нашими специалистами был успешно реализован модульный подход при проектировании главных корпусов таких ведущих перерабатывающих предприятий отрасли в Кузбассе, как ОФ «Красногорская», ОФ «Спутник», ОФ «Северная», ОФ «Распадская», ОФ «Бачатская-Коксовая», ОФ «Краснобродская-Коксовая», ОФ «Карагайлинская», в Якутии ОФ «Эльгинская», на Украине ОФ «Свято-Варваринская», ОФ «Комсомолец Донбасса», ЦОФ «Павлоградская», ЦОФ «Октябрьская» и др.

«Коралайна Инжиниринг» всегда готова оказать угольным предприятиям услуги по проектированию обогатительных фабрик и поставке современного технологического оборудования, поделиться опытом работы с проектными организациями, чтобы способствовать развитию углеобогащения в России и странах СНГ. 


\section{Технологические бункеры нового поколения для обогатительных фабрик}

\author{
КУЗНЕЦОВ Валерий Георгиевич \\ Президент ООО «Ас-Тик КП» \\ КУЗНЕЦОВ ИГорь ПетрОвИч \\ Коммерческий директор 000 «Ас-Тик КП»
}

Представлен положительный опыт выпуска в сжатые сроки в заводских условиях двадцати новых технологических бункеров, оборудованных порядка 18 т полимерных противоналипающих футеровочных пластин - Астики, путем кооперации ряда промышленных предприятий. Рекомендуется к широкому использованию обогатительными фабриками России, государств СНГ и стран Балтии.

Ключевые слова: обогатительные фабрики, технологический бункер, уголь, налипание, полимерная противоналипающая футеровочная пластина-Астики, кооперачия промышленных предприятий.

Контактная информация: e-mail: astik_kp@mail.ru; тел. /факс: +7 (495) 718-48-12

Обогащение полезных ископаемых связано с переработкой больших объемов горной массы с применением обогатительного технологического оборудования. Важное значение при этом имеют фактические характеристики взаимодействия частиц горной массы (крепость, плотность, влажность, липкость и прочее) с рабочими поверхностями технологического оборудования. Даже небольшие колебания в изменении горнотехнических и горно-геологических условий эксплуатации технологического оборудования увеличивают выход мелких фракций и засоренность добываемых полезных ископаемых, в том числе и углей, породой. Следует отметить, что порода, представленная глиной и суглинками, при определенных значениях влажности, проявляет отрицательные липкие свойства, в результате чего резко снижается эксплуатационная производительность оборудования.

Аналогичное явление происходит и с некоторыми видами пыли, образующейся в процессе измельчения углей и пород, что приводит к заштыбовке транспортных трактов и бункеров, существенно снижает производительность обогатительных фабрик.

При хранении углей и других полезных ископаемых в дозировочно-аккумулирующих бункерах, силосах и др. происходят их залипание и зависание, что значительно сокращает пропускную способность бункеров, особенно при наличии в рядовых углях глинистых включений в виде минералов монтмориллинита, коалинита, иллита и т.д. Так, по данным института обогащения твердого топлива (ИОТТ), вместимость бункеров рядового угля снижается в среднем по обогатительным фабрикам на 20-25\% из-за неудовлетворительной их разгрузки в результате существенного налипания на рабочие поверхности [1].

Таким образом, борьба с налипанием рядовых углей, угольного концентрата и других сырьевых материалов на рабочие поверхности технологического оборудования обогатительных фабрик является актуальной задачей.

Анализ существующих способов и средств борьбы с налипанием увлажненных горных масс и сырьевых материалов на рабочие поверхности экскаваторного, транспортирующего и технологического оборудования, применяемых в зарубежной и отечественной практике, а также результаты промышленных испытаний, полученных ООО «Ас-Тик КП», институтом ИОТТ в содружестве с предприятиями основных отраслей горнодобывающей промышленности, свидетельствуют о том, что наиболее эффективными и надежными средствами в эксплуатации являются твердые полимерные гидрофобные материалы, обладающие высокой износостойкостью и ударной прочностью.

Примерами таких материалов являются: импортные, сверхвысокомолекулярные типа «Supralen», «Solidur», «Tivar» и др.; отечественные, типа высокомолекулярный «Компонор РЕ3-03» и ППФП-Астики [2, 3, 4, 5, 6, 7, 8]. Однако в связи с распадом СССР работы по наработке и внедрению в производство высокомолекулярного «Компонора РЕЗ-03» были полностью прекращены, а полимерные противоналипающие футеровочные пластины - Астики (ППФП-Астики) в настоящее время выпускаются ООО «Ас-Тик КП» из полиолефинового полимерного сырья различной износостойкости и долговечности по ТУ 2246-001-22711279-2008.

Установка и крепление ППФП-Астики на рабочих поверхностях технологического оборудования осуществлялись до последнего времени в эксплуатации только в момент проведения плановых ремонтов оборудования без изменения ранее запроектированных металлических поверхностей. В этих случаях нельзя было в полной мере использовать наилучшим образом эксплуатационные характеристики самого полимерного материала, а именно сочетание гидрофобности, антифрикционности и износостойкости. Этого можно достичь только при проектировании и выпуске в заводских условиях нового технологического оборудования, базирующихся в современных экономических условиях как на кооперации ряда промышленных предприятий, так и с учетом имеющихся на современном этапе развития последних достижений в области науки и техники.

Так, в течение трех месяцев, с конца 2012 г. по февраль 2013 г., в заводских условиях предприятий по выпуску металлоконструкций осуществлено производство технологических бункеров, оборудованных ППФП-Астики, для строящейся новой технологической линии обогатительной фабрики окомкования ОАО «Михайловский ГОК» (г. Железногорск, Курской обл.). Следует отметить, что работы по 


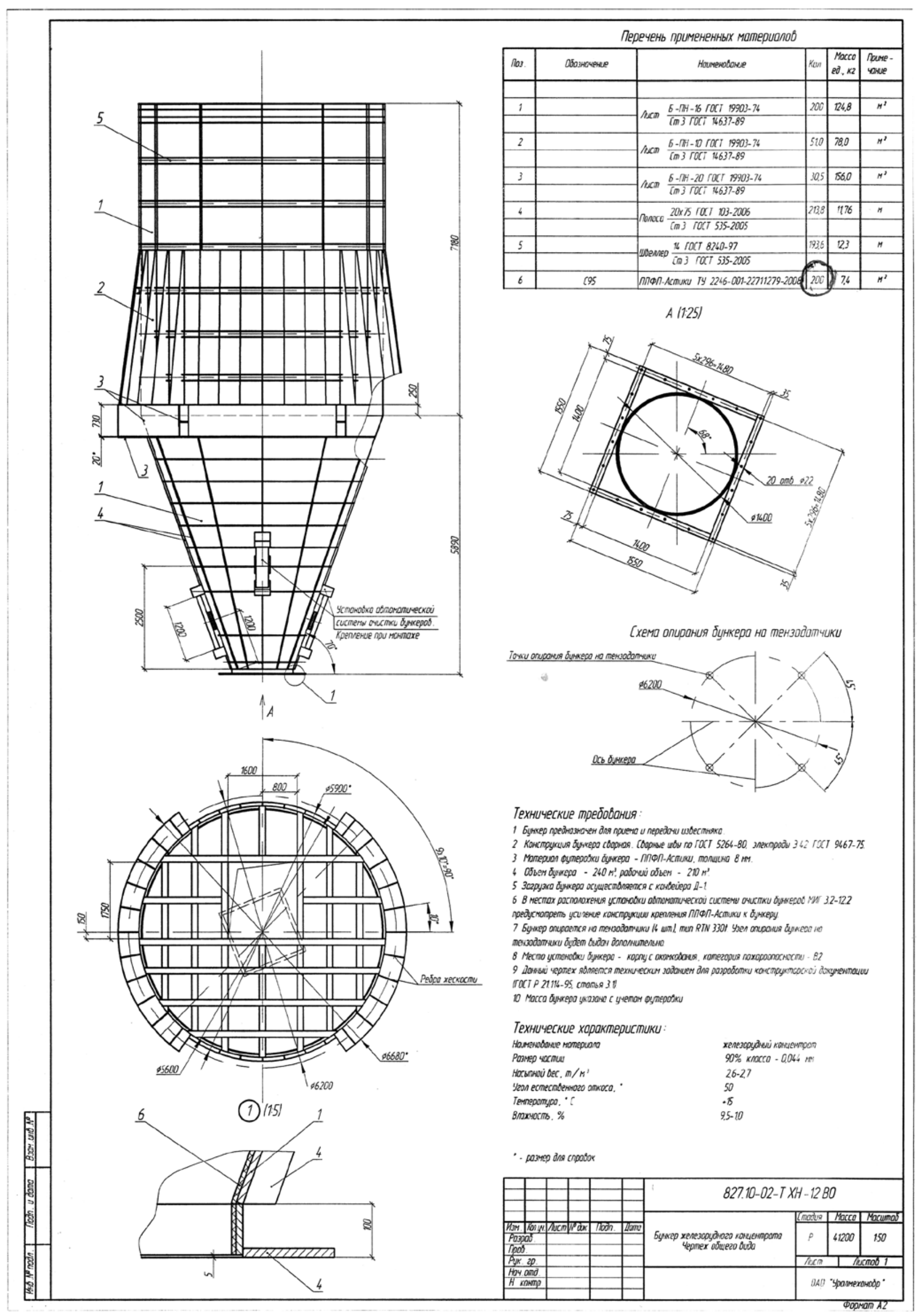

Конструктивная схема бункера с футеровкой ППФП-Астики 
выпуску нового поколения технологических бункеров выполнялись путем кооперации ряда промышленных предприятий. Координацией всех работ занималось Управление кооперации ОАО «Уралмашзавод (г. Екатеринбург).

Проектные работы по бункерам для железорудного концентрата, известняка, бентонита и шихты были выполнены OAO «Уралмеханобр» (г. Екатеринбург). Изготовление и поставку необходимых размеров и количеств ППФП-Астики с учетом минимизации отходов при раскрое осуществляло ООО «Ас-Тик КП». Выпуск технологических бункеров с футеровкой их рабочих поверхностей пластинами ППФП-Астики произвели ООО «Проммонтаж» (г. Курск) и ОАО «Таганрогстальконструкция» (г. Таганрог). Всего в сжатые сроки было изготовлено 20 новых технологических бункеров, оборудованныхпорядка 18т ППФП-Астики. Типовая конструктивная схема одного из бункеров представлена на рисунке.

Таким образом, положительный опыт заводского выпуска технологических бункеров, оборудованных ППФП-Астики, на основе кооперации ряда промышленных предприятий, может быть полезен как родственным предприятиям железорудной промышленности, так и аналогичным обогатительным фабрикам других отраслей горнодобывающей и перерабатывающей промышленности России, государств СНГ и стран Балтии.

Особенно это важно в связи с принятой в России на ближайшие годы программой проведения широкой модернизации технологического оборудования в целях повышения эффективности его использования.

\section{Список литературы}

1. Троицкий В. В., Мезрин В.В. Борьба с налипанием горной массы на рабочие поверхности транспортного и обогатительного оборудования. Обзорная информация
ЦНИИЭИуголь. Обогащение и транспортирование угля. Вып. 1. - М.: 1987. - С. 29.

2. Кузнецов В.Г., Ильченко С. В. Облицовочные листы из СВМПЭ против налипания увлажненного материала на горнодобывающем и транспортном оборудовании. Зарубежный опыт // Промышленность строительных материалов Москвы. - 1992. - №2. - С. 31-33.

3. Кузнецов В. Г., Кузнецов И. П., Алексеенко И. П. Снижение прилипания и примерзания влажных углей Черемховского и Кузнецкого месторождений на металлические стенки бункеров // Уголь. - 2004. - №5. - С. 48-50.

4. Кузнецов В. Г., Кочетов Е. В., Коврига В. В. и др. Материал «Компонор РЕ3-03» - эффективное средство борьбы с налипанием горных пород // Горный журнал. - 1989. №11. - С. 37-38

5. Кузнецов В.Г., Кузнецов И. П., Копылов С. В., Ситников С.Н. и дp. Правильный подбор полимерных противоналипающих футеровочных пластин - залог эффективной эксплуатации технологического оборудования // Горный журнал. - 2008. — №4. - С. 80-81.

6. Кузнецов В. Г., Новикова Т.Н., Кузнецов И. П. Повышение эффективности использования технологического оборудования при транспортировании и перегрузке увлажненного железорудного концентрата и офлюсованных сырых окатышей // Строительные материалы. - 2010. — №1. - С. 22-23.

7. Кузнецов В. Г., Новикова Т. Н., Кочетов Е. В., Кузнецов И. П. Повышение эффективности использования горнотранспортного оборудования тяжелого машиностроения при работе на увлажненных липких породах // Тяжелое машиностроение. - 2012. - №4. - С 36-38.

8. Кузнецов В. Г. , Кузнецов И. П. Повышение качества выпускаемой готовой продукции // Стандарты и качество. -2012 . — №8. - С. 92-93.

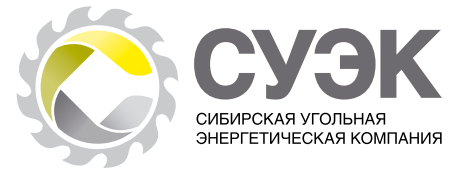

СИБИРСКАЯ УГОЛЬНАЯ
ЭНЕРГЕТИЧЕСКАЯ КОМПАНИЯ

\section{Разрез «Апсатский» добыл первый миллион тонн угля}

На разрезе «Апсатский», (Забайкальский край), входящем в ОАО «СУЭК», 26 марта 2014 г., добыта миллионная тонна угля с начала эксплуатации Апсатского месторождения.

Апсатское каменноугольное месторождение расположено в Каларском районе Забайкальского края и удалено на 36 км к северу от Байкало-Амурской магистрали и от районного центра с. Чара.

Разрез «Апсатский» пущен в эксплуатацию в июне 2012 г.

На разрезе работает самая современная техника, отвечающая лучшим мировым стандартам: экскаваторы Liebherr R954, Komatsu PC-1250, Doosan 4804, Hitachi EX1900-6, самосвалы Terex TA-400, Terex TR-100, Scania-420.

В июне 2013 г., по решению Правительства Забайкальского края, освоению Апсатского каменноугольного месторождения был присвоен статус инвестиционного проекта краевого значения. Проект предусматривает строительство угольного разреза, обогатительной фабрики и других инфраструктурных объектов.

Наша справка.

ОАО «Сибирская угольная энергетическая компания» (СУЭК) - крупнейшее в России угольное объединение по объемудобычи. Компания обеспечивает около $30 \%$ поставокугля на внутреннем рынке и примерно 25\% российского экспорта угля. Филиалы и дочерние предприятия СУЭК расположены в Забайкальском, Красноярском, Приморском и Хабаровском краях, Кемеровской области, в Бурятии и Хакасии. 


\section{Разработка нового связующего}

\section{для производства бездымных брикетов из антрацитовых штыбов}

В статье приводятся результаты исследования брикетов из антрацитовых штыбов с малотоксичным полимерным связующим, состоящим из модифицированных лигносульфонатов и раствора таллового пека в органическом растворителе. Брикеты получены методом холодного прессования с последующей термоокислительной обработкой. По физико-механическим показателям брикеты относятся к высококалорийному, среднеминерализованному, бездымному угольному топливу. Разработанное связующее позволит снизить содержание токсичных веществ в отходящих газах при сжигании брикетов у потребителей до концентраций, не превышающих предельно допустимых значений.

Ключевые слова: антрацитовые штыбы, связующее, брикеты, прессование, прочность на сжатие, водопоглощение.

Контактная информация:

e-mail:2086ramblerru1@rambler.ru

В настоящее время производители энергетического угля не получают ощутимой прибыли, как на внутреннем рынке, так и от его экспорта. Роста потребления на внутреннем рынке можно ожидать только в долгосрочной перспективе при переходе крупных потребителей газа на уголь. Экспорт угля также становится нерентабельным из-за географической удаленности большинства добывающих предприятий от потенциальных зарубежных потребителей. Таким образом, назрела острая необходимость в развитии переработки угля, которая может обеспечить качественное изменение его потребительских свойств и тем самым позволит выйти за пределы рынка энергетического угля. $\mathbf{H a -}$ иболее перспективным направлением в переработке угля является брикетирование, которым занимаются все развитые угледобывающие страны мира.

Объем разведанных запасов угля в России, по приблизительным данным, составляет 193,3 млрд т, из них 6,8 млрд т антрацитов [1]. Добыча антрацита в действующих шахтах осуществляется в основном угольными комбайнами, в результате чего значительную часть нарезаемого рядового угля составляют относительно дешевые штыбы и угольная мелочь.

Поэтому одним из главных направлений перехода на резервное энергетическое топливо вместо природного газа и нефти являются брикеты, полученные из антрацитового штыба с содержанием серы не более $1 \%$. Одной из причин, сдерживающих развитие углебрикетного производства в нашей стране, является отсутствие дешевого и нетоксичного связующего.

Основным связующим веществом для брикетирования антрацитов до недавнего времени являлись нефтепродукты [2]. Брикеты с нефтебитумным связующим отличаются невысоким качеством: недостаточно термоустойчивы, при горении образуют большое количество мелочи, что увеличивает провал и недожог топлива. Кроме того, брикеты слипаются при транспортировке и дробятся при разгрузке.

Имеются сведения о применении в качестве связующего побочных продуктов сульфитного производства. Для брикетирования применяются и неорганические вещества: гашеная известь, растворимое жидкое стекло, цементы, каустический магнезит и доломит, гипсовые связующие, а также различные комбинации этих веществ [3].

Цель данной работы - разработка малотоксичного гидрофобного комплексного связующего материала, превосходящего нефтебитумы по технологическим, санитарно-гигиеническим и экономическим требованиям, для создания экологически безопасной технологии производства бездымных брикетов из антрацитовых штыбов.

В качестве основы для разработки комплексного связующего материала использовали природный полимерный материал - технические лигносульфонаты (ТЛС), образующиеся на целлюлозно-бумажных комбинатах (ЦБК) при производстве сульфитной целлюлозы [4]. Из нескольких миллионов тонн ТЛС, получаемых при переработке древесины на целлюлозу, только несколько сот тысяч тонн используются как товарный продукт. Из-за ограниченного потребления ТЛС сжигаются и сливаются в водоемы, нанося тем самым значительный вред окружающей среде. В связи с этим использование нового связующего материала на основе малотоксичных ТЛС в брикетной технологии позволит параллельно решить одну из важнейших задач предприятий целлюлозно-бумажной промышленности максимальную их утилизацию.

Основным недостатком товарных лигносульфонатов, получаемых на ЦБК в виде жидких концентратов, является их недостаточная эластичность и низкая прочность образуемой ими пленки. В последние годы предпринимались попытки улучшения (стабилизации) свойств ТЛС путем их 
Состав и свойства модификатора КООС

\begin{tabular}{|c|c|c|c|c|c|c|c|}
\hline \multicolumn{4}{|c|}{ Содержание ингредиентов, мас. \% } & \multicolumn{3}{|c|}{ Показатели свойств } \\
\hline KO 1 & КО 2 & КО 3 & КО 4 & KO 5 & Вязкость, С, по B3-1.5,4 & $8-12$ \\
\hline $38-46$ & $22-30$ & $7-11$ & $4-8$ & $3-45$ & $30-60$ & \\
\hline
\end{tabular}

модифицирования. Однако предложенные модификаторы среди индивидуальных химических веществ незначительно повышают связующие свойства ТЛС, приводят к их удорожанию.

Поиск новыхмодификаторов проводился среди кубовых остатков органического синтеза (КООС) различных химических производств. При этом круг исследуемых объектов ограничивался тем, что KOOC должны содержать двухи более функциональные вещества, способные давать поперечные химические связи между макромолекулами лигносульфонатов с образованием сетчатого полимера в условиях тепловой обработки угольных брикетов. Такие вещества, в частности, содержатся в кубовых остатках производств 1,4-бутандиола (КО 1), поливинилпирролидона (КО 2), метилпирролидона (КО 3), моноэтаноламина (КО 4), $\gamma$-бутиролактона (КО 5), которые были использованы при изготовлении нового модификатора, представляющего собой сложную смесь КООС [5] (см. таблицу).

Для приготовления модификатора указанная в таблице смесь кубовых растворялась в воде в объемном соотношении KOOC: $\mathrm{H}_{2} \mathrm{O}=6 / 1$. Модифицирование ТЛС проводили путем их смешивания с модификатором КООС в течение 2-3 мин до достижения жидкого состояния. Установлено, что модификатор резко снижает вязкость ТЛС и повышает кроющие свойства связующего.

Модифицированные лигносульфонаты, содержащие $90 \%$ ТЛС и $10 \%$ КООС, (МЛС), по параметрам острой токсичности относятся к четвертому классу малоопасных веществ, не обладают кожно-резорбтивным действием, не оказывают местнораздражающего и аллергического действия.

С целью гидрофобизации МЛС использовали второй компонент комплексного связующего - раствор таллового пека в скипидаре. Талловый пек (ТП) - многотоннажный побочный продукт сульфат-целлюлозного производства. В настоящее время ТП не находит достаточно квалифицированного применения, и значительная его часть сжигается в смеси с мазутом непосредственно на сульфат-целлюлозных предприятиях. Расширение его использования является актуальной задачей для лесохимических предприятий.

Талловый пек, получаемый при переработке сырого таллового масла, содержит четыре основные группы соединений:жирные и смоляные кислоты, окисленные и неомыляемые вещества, а также эфиры жирных кислот [6].

Для технологии холодного брикетирования антрацитового штыба связующее должно быть одновременно и вязким, и достаточно жидкотекучим. Этому требованию отвечает разработанное комплексное связующее. Совмещение связующего МЛС с раствором таллового пека в скипидаре желательно проводить в момент приготовления шихты.

В исследованиях были использованы рядовые штыбы марки А сорта АШ класса 0-6 мм шахты «Обуховская» Ростовской области с содержанием серы менее $1 \%$. В соответствии с требованиями традиционной технологии брикетирования исходные штыбы были подвергнуты сушке до влажности 2-3\%. Подготовку усредненной угольной пробы осуществляли следующим образом: сначала готовили три фракции 0-0,63 мм; 0,63-2,5 мм и 2,5-6 мм, затем их тщательно смешивали в процентном соотношении 30:60:10.

Такой фракционный состав шихты был принят исходя из опыта работы зарубежных брикетных фабрик. Большое содержание крупных зерен (более 6 мм) отрицательно сказывается на прочности брикетов, так как при прессовании такие частицы легко растрескиваются. Чрезмерная запыленность угля частицами менее 1 мм приводит к резкому возрастанию расхода связующих.

Перемешивание угольной шихты со связующим осуществлялось в лабораторном лопастном смесителе. Время перемешивания - 5-6 мин. Содержание связующего от массы угля составляло 8-12\%. Количество шихты для прессования (143 г) определялось необходимостью изготовления стандартных брикетов цилиндрической формы размером (диаметром) 50×50 мм.

Прессование подготовленной шихты осуществляли на универсальной испытательной машине ГРМ-1 при удельном давлении от 15 до 75 МПа.

Отформованные брикеты подвергались термообработке в сушильном лабораторном электрошкафу СНОЛ3,5.3,5.3,5/3-М-2 при 190, 220 и $250{ }^{\circ} \mathrm{C}$. Температура измерялась ртутным термометром с точностью $\pm 10^{\circ} \mathrm{C}$. Время тепловой обработки брикетов: 60, 90 и 120 мин.

После термообработки готовые брикеты охлаждали при комнатной температуре без принудительной вентиляции воздуха. Через 24 ч готовые брикеты подвергали испытаниям. Качество термообработанных брикетов оценивали в соответствии с действующими в России стандартами и техническими условиями на брикетное топливо.

В целях оптимизации температурного режима изучены свойства брикетов на основе комплексного связующего, состоящего из $60 \%$ МЛС и $40 \%$ раствора таллового пека

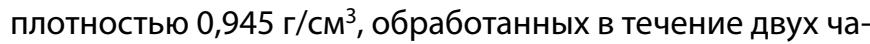
сов при температурах: 190, 220 и $250^{\circ} \mathrm{C}$ (рис. 1). Указанной плотности отвечает $50 \%$ таллового пека в скипидаре.

Как видно из рис. 1, наибольшую прочность комплексное связующее сообщает угольным брикетам при $220^{\circ} \mathrm{C}$. Эта температура для отверждения брикетов является оптимальной: у брикетов достигнута наибольшая прочность 10,7 МПа. Брикеты после двухчасового пребывания в воде теряют прочность всего на $13 \%$. Это свидетельствует о высокой степени водостойкости разработанного комплексного связующего. Водопоглощение брикетов составляет всего 1,3-2,5\%.

Отмечены интересные зависимости водопоглощения брикетов от температуры отверждения и времени их стояния в воде. Так, способность поглощать воду у брикетов с двухчасовым стоянием в воде выше у тех образцов, кото- 

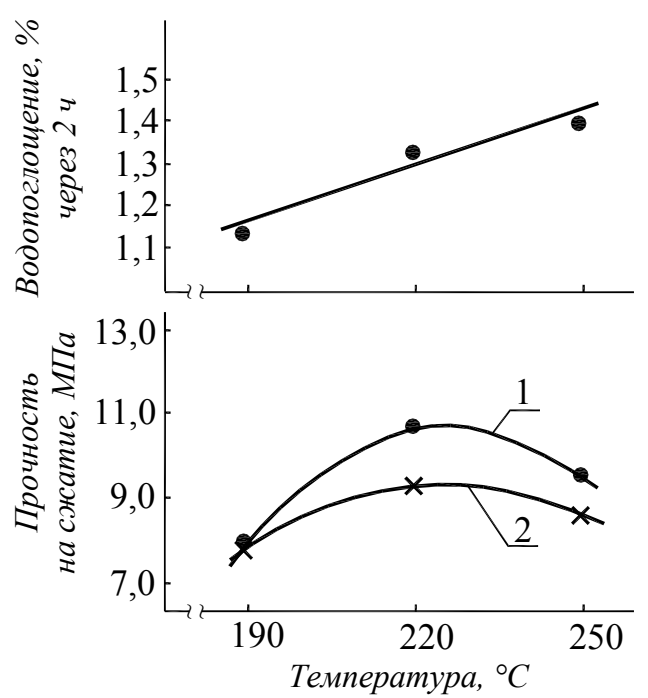

Pис. 1. Зависимость прочности и водопоглощения брикетов от температуры их отверждения: 1 - отвечает прочности брикетов после их стояния на воздухе в течение 24 4; 2 - отвечает прочности брикетов после их двухчасового пребывания под водой

рые отверждались при более высокой температуре. Объясняется это тем, что в поверхностном слое таких брикетов содержится меньше гидрофобного материала, и поэтому водопоглощение их больше. Обратная зависимость наблюдается для образцов с суточным пребыванием в воде. В этом случае водопоглощение определяется объемным фактором брикета, а не его поверхностью.

Была проведена еще одна серия экспериментов по исследованию влияния на свойства брикетов удельного давления прессования угольной шихты (рис. 2). Для технологии холодного прессования важно, чтобы отформованные брикеты имели в сыром состоянии прочность достаточную, чтобы выдержать различные технологические манипуляции.

Как видно из рис. 2, с увеличением удельного давления прессования шихты возрастает прочность сырых брикетов. Наибольшую прочность (0,2 МПа) имеет брикет, отформованный при достаточно высоком удельном давлении 60 МПа. Однако это удельное давление прессования нельзя считать оптимальным. Это хорошо видно из кривых прочности образцов, отвержденных в течение двух часов при температуре $220^{\circ} \mathrm{C}$. Кривая прочности брикетов с $8 \%$ комплексного связующего имеет максимум, отвечающий удельному давлению прессования 30 МПа. Это удельное давление прессования может служить ориентиром для отработки оптимальных режимов прессования в производственных условиях. Видимо, оно может колебаться в ту или иную сторону, но быть не менее 20 МПа и не более 45 МПа. Падение прочности отвержденных образцов-брикетов с $12 \%$ комплексного связующего свидетельствует о том, что это количество связующего в шихте является избыточным.

Из анализа газов при термообработке и сжигании брикетов установлено, что концентрация выделяющихся токсичных веществ находится на уровне значительно более низком, чем их ПДК в рабочей зоне.
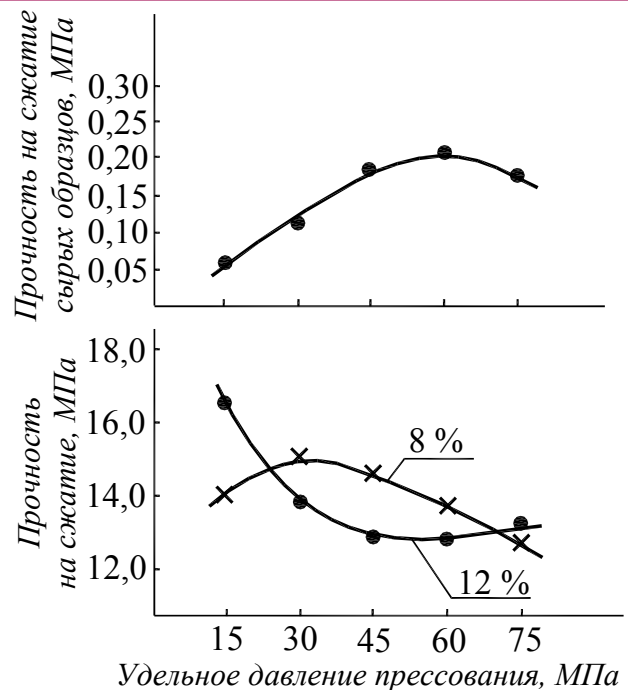

Pис. 2. Зависимость прочности сырых и отвержденных брикетов в течение 2 ч при температуре $220^{\circ} \mathrm{C}$ от удельного давления прессования для 8 и $12 \%$ комплексного связующего в составе угольной шихты

\section{Выводы}

1. На основе модифицированных ТЛС и ТП разработано принципиально новое малотоксичное гидрофобное связующее для производства бездымных брикетов из антрацитовых штыбов.

2. Изготовленные брикеты по показателям механической прочности и атмосферо-водоустойчивости значительно превышают требования потребительских стандартов на бытовое брикетное топливо, предъявляемые на отечественном и зарубежном рынках.

3. Использование в составе разработанного комплексного связующего гидрофильных модифицированных ТЛС дает возможность применять для производства брикетов рядовые влажные антрацитовые штыбы. Эта принципиальная новизна кардинально изменит технологию брикетирования путем исключения из технологической схемы дорогостоящего, экологически вредного корпуса сушки и резко уменьшит капиталовложения при проектировании и строительстве углебрикетной фабрики.

\section{Список литературы}

1. Таразанов И. Г. Итоги работы угольной промышленности России за январь-июнь 2013 года // Уголь. - 2013. №9. - C. 47-61.

2. Крохин В.Н. Брикетирование углей - М.: Недра, 1984. - $216 \mathrm{c}$.

3. Елишевич А. Т. Брикетирование полезных ископаемых. - М.: Недра, 1989. - 300 с.

4. Сапотницкий С. А. Использование сульфитных щелоков. - М.: Лесная промышленность, 1981. — 224 с.

5. Евстифеев Е. Н. Модифицированные лигносульфонаты и смолы для литейных стержней и форм: Монография/ ДГТУ, 2011. - 393 с.

6. Головин А. И., Трофимов А. Н., Узлов Г. А. и др. Лесохимические продукты сульфатцеллюлозного производства М.: Лесная промышленность, 1988. - 288 с. 


\section{Моделирование напряженно-деформированного состояния массива пород вблизи очистных блоков с учетом временного фактора}

\author{
ИСАБЕК Туяк Копеевич \\ Заведующий кафедрой \\ «Разработка месторождений \\ полезных ископаемых» КарГТУ, \\ доктор техн. наук, профессор
}

\section{АЛИЕВ Самат Бекетаевич \\ Заместитель директора \\ Департамента развития \\ предпринимательской деятельности \\ Евразийской экономической комиссии, \\ доктор техн. наук, профессор}

\section{КАМАРОВ Рымгали Кумашевич}

Дочент кафедры «Разработка месторождений полезных ископаемых» КарГТУ, канд. техн. наук

\section{ИМАШЕВ Аскар Жанболатович \\ Старший преподаватель кафедры \\ «Разработка месторождений \\ полезных ископаемых» КарГТу, \\ магистр горного дела}

\section{БАХТЫБАЕВА Асель Серикбаевна \\ Старший преподаватель кафедры \\ «Маркшейдерское дело и геодезия» КарГту, \\ магистр горного дела}

В статье приведены результаты исследований устойчивости горных пород вокруг очистных выработок в условиях рудника «Ушкатын-3» АО «Жайремский ГОК». Определены условные зоны неупругих деформаций (УЗНД) вокруг очистных пространств с учетом временного фактора. Исследовано влияние коэффициента бокового распора на формирование УЗНД.

Ключевые слова: массив, напряжение, моделирование, боковой распор, временной фактор, долговечность, геомеханика.

Контактная информация:

e-mail:tyiak@mail.ru; imashev_85@mail.ru

Математическое моделирование по определению УЗНД вокруг очистных блоков проводилось на примере условий рудника «Ушкатын-3». Данное месторождение представлено крутопадающими рудными телами, угол залегания составляет 80-85, а их мощность колеблется в диапазоне от 2 до 6 м. В настоящее время отработка железомарганцевых рудных тел осуществляется комбинированным (открытоподземным) способом.

Целью данного исследования является определение влияния коэффициента бокового распора на изменение размеров УзНД вблизи очистных блоков.

Для моделирования напряженно-деформированного состояния массива пород вблизи очистных выработок с учетом временного фактора используется методика, разработанная доктором техн. наук Б. Н. Цай [1] на кафедре ШПС КарГТУ, основанная на кинетической теории прочности твердых тел.

Сущность методики заключается в следующем. Изначально определяются максимальные касательные напряжения вблизи очистных выработок. Затем на поле напряжений накладываются прочностные свойства массива. С помощью уравнений кинетической теории прочности переходят к долговечности пород [2].

Для моделирования были приняты следующие исходные данные:

— глубина ведения работ 160 м;

- ширина очистной выработки 3-6 м;

- высота очистной выработки 48 м;

- угол наклона сечения выработки $85^{\circ}$;

- прочность вмещающих пород на одноосное сжатие $64 \mathrm{MПа,} \mathrm{48МПа,} 24$ МПа.

Расчетная схема приведена на рис. 1

С целью определения характера деформационных процессов, протекающих вблизи очистных выработок горизонта +192 м при прочности вмещающих пород 68 МПа, было выполнено моделирование с помощью компьютерной программы «СИГМА 2», разработанной на кафедре

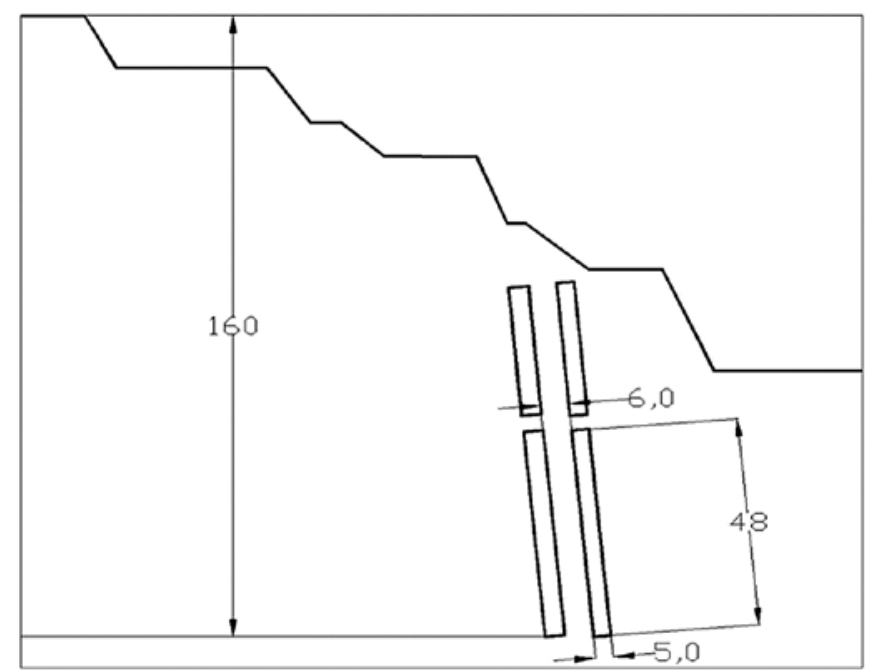

Puc. 1. Расчетная схема 
РМПИ. В основу компьютерной программы были положены результаты исследований доктора техн. наук Б. Н. Цай [3].

Как было отмечено выше, изначально определяются максимальные касательные напряжения вблизи очистной выработки. На рис. 2 приведены изолинии максимальных касательных напряжений.

Значения максимальных касательных напряжений, указанные в шкале, приведены в МПа.

Как видно из рис. 2 максимальные значения напряжений отмечены в кровле и в почве очистной выработки. В боках очистной выработки напряжения минимальные. Концентрация максимальных касательных напряжений в кровле и в почве выработки отрицательно сказывается на устойчивости межэтажных целиков. В свою очередь устойчивость межэтажных целиков зависит от прочности пород. На рис. 3 приведена картина распределения зон неупругих деформаций вблизи очистной выработки при крепости пород 68 МПа.

Как видно из рис. 3, массив вблизи очистной выработки относительно устойчив. Вуглах очистной выработки наблюдаются незначительные зоны неупругих деформаций глубиной не более 1 м. Наличие подобных зон объясняется высокой концентрацией напряжений в углах прямоугольного сечения. Для того чтобы снизить концентрации напряжений в углах очистной выработки, последние необходимо закруглить.

Отсутствие неупругих деформаций в боках очистной выработки не исключает проявления упругих деформаций. На рис. 3 цветными линиями приведены изолинии долговечности, соответствующие различным моментам времени с момента образования обнажения. Долговечность пород приведена в секундах. Сущность понятия долговечности заключается в способности горных пород сохранять длительное время целостность под действием заданных напряжений, то есть долговечность пород показывает, за какой промежуток времени произойдет разрушение пород при заданных значениях напряжений [4].

На рис. 4 приведена шкала соответствия цветов заданному промежутку времени.

Из рис. 4 следует:

- 1000 секунд равны 17 минутам - происходит образование условных зон неупругих деформаций в момент проведения выработки;

- 100 тыс. секунд равны 28 ч, т. е. через сутки с момента образования обнажения;

- 10 млн секунд - почти 4 мес.;

- 1 млрд секунд - почти 32 года.

Для изучения характера деформаций вблизи очистных выработок снизим прочность пород до 48 МПа, что соответствует прочности алевролитов.

На рис. 5 приведена картина распределения изолиний долговечности вблизи очистной выработки при прочности пород на одноосное сжатие, равное 48 МПа.
Как видно из рис. 5, характер распределения изолиний долговечности пород подобен характеру распределения изолиний долговечности при прочности пород 64 МПа. Зоны неупругих деформаций также формируются в кровле и в почве выработки. Максимальная глубина распространения изолиний долговечности не превышают 2 м. Результаты моделирования напряженно-деформированного состояния массива вблизи очистной выработки при различных сочетаниях вертикальных и горизонтальных главных напряжений показали, что при крепости пород свыше 48 МПа нельзя отследить влияния коэффициента бокового распора на характер распределения изолиний зон неупругих деформаций.

С целью определения влияния коэффициента бокового распора на устойчивость очистных выработок примем прочность пород равной 20 МПа, что соответствует прочности сильнотрещиноватых или обводненных пород. 


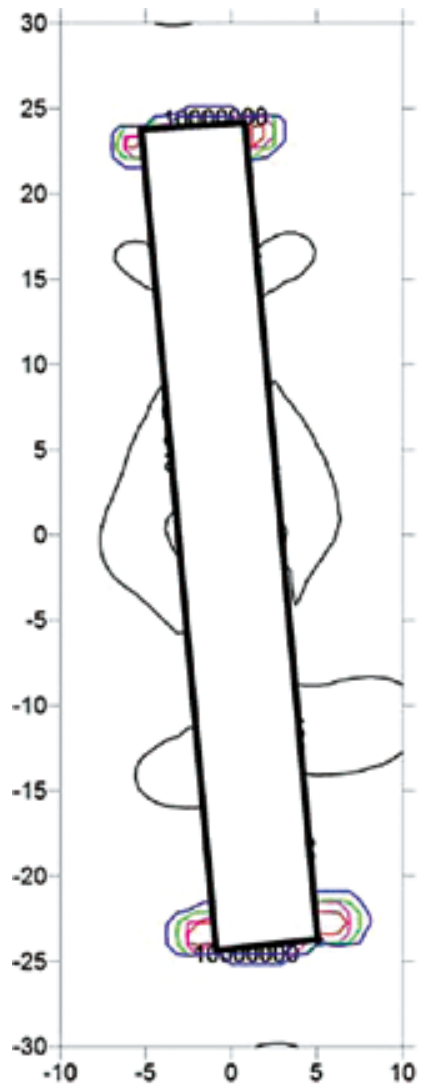

Рис. 5. Изолинии долговечности вблизи очистной выработки при прочности пород, равном $48 \mathrm{MПа}$ a

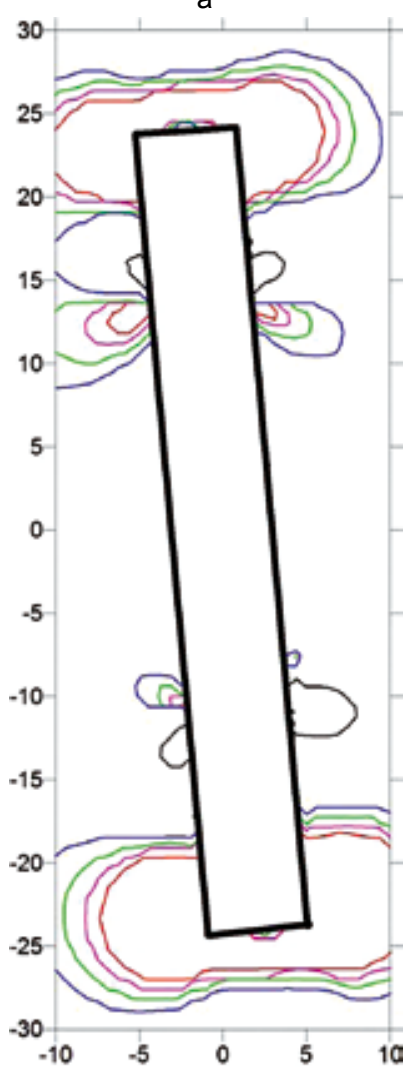

6

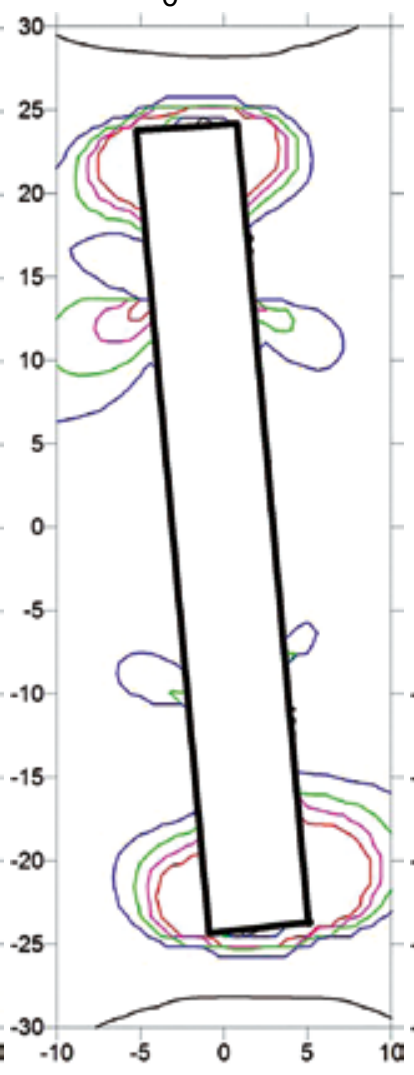

B

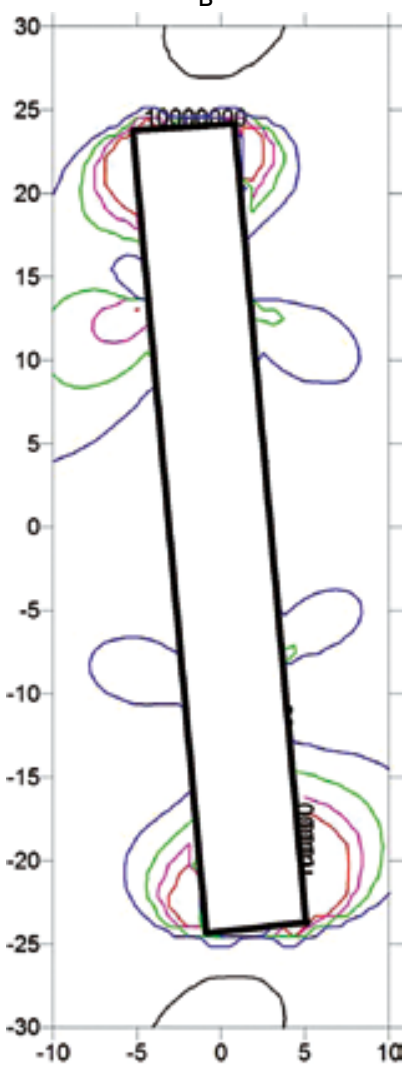

Pис. 6. Распределение изолиний зон неупругих деформаций при различных значениях коэффричиента бокового распора: $a$ - гидростатическое давление $\lambda=1 ; \sigma-\lambda=0,5$; $B-\lambda=0,33$

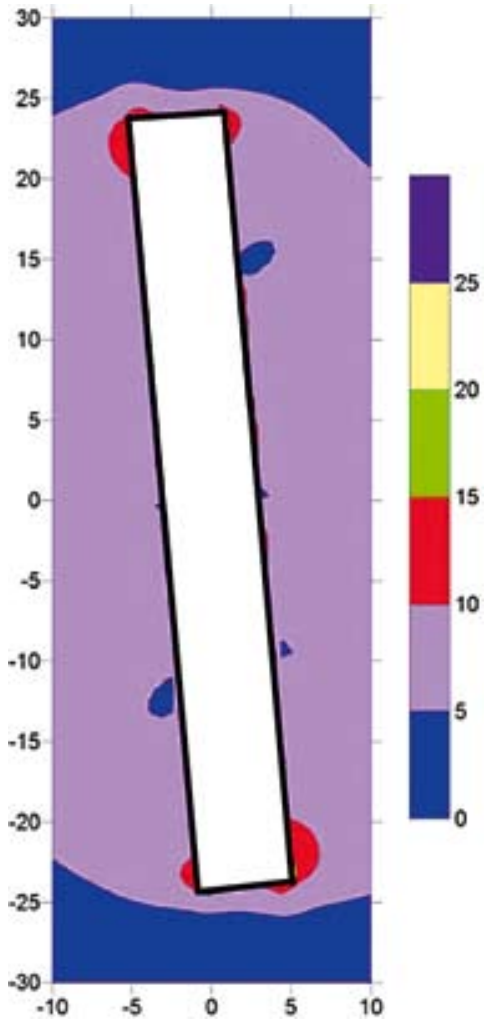

Рис. 7. Изолинии напряжений при коэффициенте бокового pacnopa $\lambda=0,33$
Как видно из рис. 6, основная доля деформаций наблюдается также в кровле и в почве выработки.

Но за счет малой прочности пород размеры УЗНД значительно выше рассмотренных ранее. Снижение коэффициента бокового распора приводит к перераспределению напряжений, в результате изолинии УЗНД вытягиваются в сторону боков выработки. Для наглядности перераспределения напряжений в результате изменения коэффициента бокового распора, приведем изолинии напряжений при $\lambda=0,33$ для рассмотренного примера (рис. 7).

Сравнение рис. 2 и 7 показало, что в последнем случае в боках выработки возникают напряжения от 5 до 10 МПа:

- условные зоны неупругих деформаций первоначально формируются в кровле и в почве очистной выработки;

- при прочности пород свыше 48 МПа коэффициент бокового распора не влияет на размеры УзНд;

- при менее прочных породах изменение коэффициента бокового распора приводит к росту деформаций в боках выработки.

\section{Список литературы}

1. Цай Б.Н. Термоактивационная природа прочности горных пород. - Караганда: КарГТУ, 2007. - 204 с.

2. Цай Б.Н., Колоколов С.Б. Некоторые аспекты развития зоны неупругих деформаций во времени // Известия вузов. Горный журнал. — 1990. — №4. -

\section{С. 31-34.}

3. Цай Б. Н. Малахов А. А., Бахтыбаев Н.Б. Обоснование параметров крепления выработок с учетом срока их службы // Горный журнал Казахстана. - 2007. №2. - C. 19-21.

4. Методика определения нагрузок на крепь и смещений пород вблизи капитальных и подготовительных выработок с учетом временного фактора. - Караганда: ТОО «Карагандагипрошахт», 2008. 


\section{Результаты дистанционного зондирования растительных экосистем и рельефа горнопромышленных ландшафтов разреза «Назаровский»}

\begin{abstract}
В статье представлены результаты космического зондирования структурыназемных растительныхэкосистем на породных отвалах угольного разреза «Назаровский». Установлено негативное влияние водной эрозии на формирование горнопромышленных ландшафтов на территории отработанной части Назаровского угольного месторождения.

Ключевые слова: добыча угля открытым способом, породные отвалы, космическое зондирование, наземные экосистемы, рекультивация земель, водная эрозия. Контактная информация: e-mail:zenkoviv@mail.ru
\end{abstract}

В бывшем СССР добыча угля вначале 1990-хгг. составляла 700 млн т в год. На долю открытого способа приходилось более половины этого объема. В последние годы РФ занимает одно из первых мест в мире по добыче угля. Открытый способ его добычи традиционно развивается опережающими темпами. В районах с масштабной добычей угля открытым способом к настоящему времени накопилось огромное количество экологических проблем, и в основном это проблемы устойчивого формирования экосистем на углепородных отвалах. В эпоху научно-технической революции с освоением космического пространства бурное развитие получили методы космического зондирования состояния природных ресурсов. Это упрощает контроль за состоянием горнопромышленных ландшафтов, рекультивированных угольными разрезами. Но, для того, чтобы делать выводы и заключения по результатам обработки космоснимков, необходимо представлять технологические последствия производства горных работ в увязке с геологическим строением отрабатываемого месторождения.

Методика наших исследований прошла апробацию на отработанном поле разреза «Назаровский» и на действующем разрезе. Разработку вскрышныхпород и добычу угля (зачистка почвы пласта) производят карьерными экскаваторами
ЭКГ-8и, ЭКГ-10, цепным и роторным экскаватором фирмы «Такраф». На добычных работах при отработке угольного пласта (основной объем) используют роторные экскаваторы ЭР-1250. Во всех случаях применяют карьерный транспорт: железнодорожный или конвейерный.

Характерной особенностью разработки угольных месторождений КАТЭКа является применение бестранспортных систем разработки нижних вскрышных уступов с применением в настоящее время цепного ERs (K) -800 и роторного экскаватора SRs (K) -4000 («Такраф»), а в предыдущие годы использовали шагающий экскаватор ЭШ-100/100 УзТМ. Подобные системы разработки широко используют на разрезах в Западной и Восточной Сибири, в Читинской области, в Хабаровском и Приморском краях.

Мощность вскрышных пород на разрезе «Назаровский» изменяется в пределах от 20 до 70 м. Породы вскрыши представлены суглинками (иногда илистыми), глинами, песчано-галечниковыми отложениями, глинистыми песчаниками, алевролитами, сажистыми углями. В почве пласта «Мощный» залегают преимущественно алевролиты, реже - аргиллиты и песчаники.

Исследования динамики восстановления наземных растительных экосистем проводились на действующих участках «Ачинский» и «Чулымский» разреза «Назаровский» (рис. 1).

На месте отработанного угольного пласта размещены внутренние отвалы вскрышных пород. Контуры горного отвода, в которых на начальном этапе начинались горные работы на каждом из участков, спланированы для нанесения почвенного слоя. Так были выделены два участка рекультивации - №1 и №2. В ходе развития горных работ рельеф горнопромышленных ландшафтов не планировался и к настоящему времени представляет мелкоскладчатую поверхность, сформированную при работе горнотранспортного оборудования. Анализ динамики формирования растительных экосистем на протяжении 10 


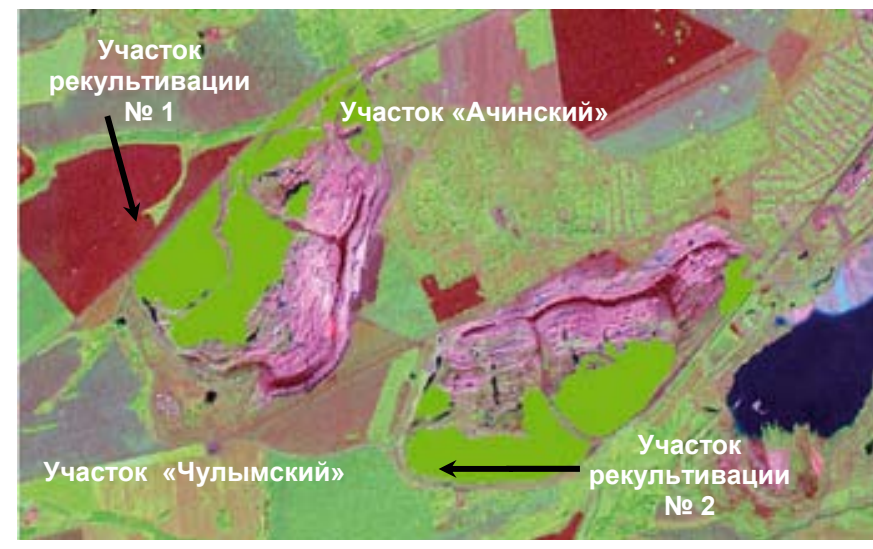

Puс. 1. Границы растительной экосистемы на внутренних отвалах разреза «Назаровский» по состоянию на 20012.

лет показывает - заселение растительностью происходит с запозданием на 3-4 года с момента отсыпки породных отвалов (рис. 2).

Причем мелкоскладчатая поверхность достаточно равномерно заселяется травянистой и кустарниковой растительностью без нанесения на ее поверхность почвенного слоя, поскольку в тело породных отвалов укладываются глины, песчаники, остатки почвенных слоев, т.е. потенциально плодородные горные породы.

В целом динамика формирования наземных экосистем положительная, что подтверждается результатами расчетов, представленных в таблице.

На разрезе «Назаровский» породные отвалы отсыпают с 1950 г. В настоящее время западная часть месторождения отрабатывается двумя участками, которые в перспективе должны сомкнуться в один карьер. В восточной части месторождения на отработанной его части сформирован горнопромышленный ландшафт. На месте отработанного угольного пласта размещены внутренние отвалы вскрышных пород (рис. 3).

На отработанной части месторождения сформирован горнопромышленный ландшафт, состоящий из следующих элементов рельефа. Нерабочий борт карьера (вскрышные и добычные уступы в конечном положении) засыпан инертной подушкой из вскрышных пород с углом откоса до $30^{\circ}$. Откос последней отвальной заходки внутреннего отвала сочленяется в плане с откосом насыпи над угольным пластом. В результате образуется локальное понижение рельефа, в котором скапливаются талые и дождевые воды. Последние при их концентрации представляют собой водные потоки, размывающие откосы техногенного рельефа.

На территории старовозрастных породных отвалов широко распространены как начальные эрозионные формы в

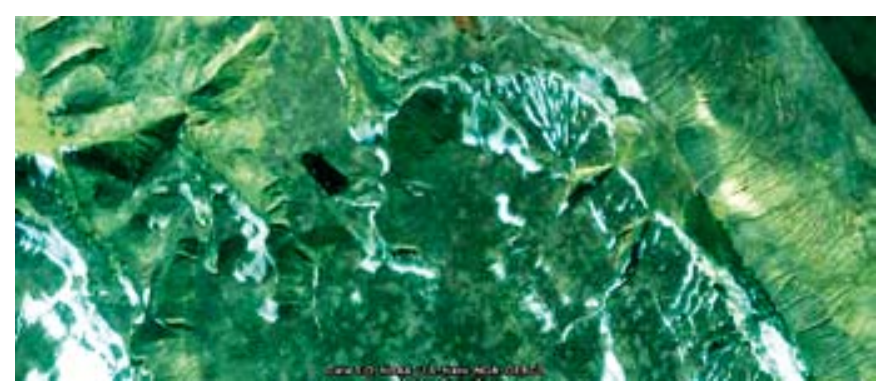

Puс. 3. Фрагмент горнопромышленного ландшафта, формирующегося при участии водной эрозии, на отработанном поле Назаровского угольного месторождения

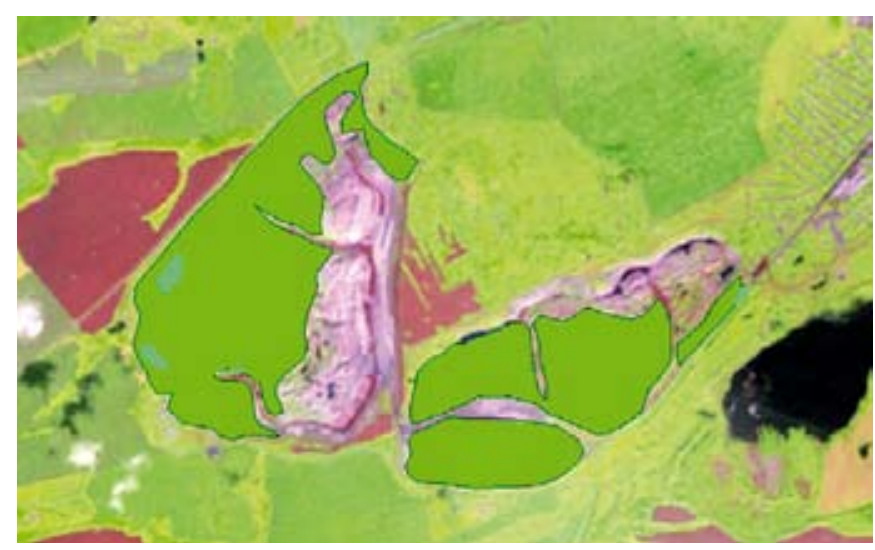

Pис. 2. Границы растительной экосистемы на внутренних отвалах разреза «Назаровский» по состоянию на 20102.

\section{Площадь растительного покрова на разрезе «Назаровский»}

\begin{tabular}{|c|c|c|}
\hline Год & $\begin{array}{c}\text { Травянистая } \\
\text { растительность, га }\end{array}$ & $\begin{array}{c}\text { Кустарниковая } \\
\text { растительность, га }\end{array}$ \\
\hline 2001 & 580,2 & - \\
\hline 2010 & 1177,8 & 23,4 \\
\hline
\end{tabular}

виде промоин (рытвин), приуроченные к откосам незадернованных склонов отвалов, так и активно формирующиеся овраги. В плане овраги имеют линейную форму на откосах и извилистую форму - на поверхности отвалов. Генеральный продольный профиль их соответствует направлению и форме склона, на котором они развиты. Водная эрозия формирует поверхность инертной породной насыпи над угольным пластом в виде многочисленных водопропускных канав переменным сечением. Комбинация канав имеет в плане вид сетки. Поскольку воздействие эрозии постоянное во времени, то и растительность в этом секторе полностью отсутствует.

В этой части горизонтальные поверхности участков внутренних отвалов спланированы на разных высотных отметках, поэтому образовываются каскадные водотоки, которые переливаются с более высоких горизонтальных участков на менее низкие. Всего на территории горнопромышленного ландшафта, созданного в период добычи угля с 1970 по 1995 гг., в ходе проявления водной эрозии образованы: 21 овраг, формирующий вторичный рельеф, и более 100 водопропускных мелких канав, принимающих участие в трансформации рельефа.

Таким образом, в развитии наземных экосистем на породных отвалах угольных разрезов КАТЭКа наблюдается некоторое запаздывание по времени, но в целом картина экологически приемлемая. Вместе с тем отмечается то, что идеально спланированные поверхности участков внутренних отвалов на разных высотных отметках способствуют формированию каскадных водотоков талых и дождевых осадков. Это приводит к выносу из тела отвала и переотложению горных пород, что в конечном итоге способствует интенсивному разрушению целостности рельефа рекультивированных горнопромышленных ландшафтов. По нашему мнению, необходим пересмотр ГОСТов на рекультивацию земель, проектирование горных работ по которым не способствует охране окружающей среды, а, наоборот, косвенно и прямо приводит к ухудшению экологической обстановки в районах с добычей угля открытым способом. 


\title{
Печорскому угольному бассейну - 90 лет
}

\author{
ИЕВЛЕВ Алексей Анатольевич \\ Руководитель Геологического музея им. А. А. Чернова \\ Института геологии Коми научного чентра \\ Уральского отделения РАН, \\ канд. геол. -минер. наук
}

Минуло 90 лет с тех пор, как в отчете о работах Печорского геологического отряда Севэкспедиции летом 1924 г. профессор А.А. Чернов впервые сформулировал судьбоносный для Европейского Севера России и Республики Коми вывод: «Таким образом, в настоящее время начинают выступать на СевероВостоке европейской части СССР неясные контуры большого каменноугольного бассейна, который естественно назвать Печорским» [1]. По тогдашним представлениям А.А. Чернова, бассейн имел форму клина, острие которого обращено к югу (бассейн р. Косью), а широкая часть к северу, и эту северную границу еще предстояло установить дальнейшими изысканиями. Вывод А. А. Чернова был далеко не тривиальным, и он сам признавался: «Когдая яриступал ксистематическомуисследованию Печорского края, то не ожидал, что наши пермские отложения будут богаты мощными пластами угля, потому что нигде на Урале нет угля в пермской системе. Открытие столь мощных углей было для меня неожиданным» [2].

Руководящиехозяйственные органы Страны Советов очень серьезно отнеслись к научному предвидению А. А. Чернова. В 1925 г. Архангельская губернская и Северо-Восточная областная плановые комиссии опубликовали следующую информацию: «Бюро съездов по изучению производительных сил при Госплане СССР сообщило Северо-Восточной областной плановой комиссии, что разведка, произведенная проф. А.А. Черновым, дала положительные результаты. По его мнению, в настоящее время начинают выступать на северо-востоке Европейской части СССР неясные контуры каменноугольного бассейна» [3]. Уже в июне 1925 г. Северо-Восточная областная плановая комиссия провела в Архангельске первую Конференцию по изучению производительных сил и народного хозяйства СевероВосточной области, на которой первым вопросом повестки значилось «Залежи каменного угля на Севере и возможность их эксплуатации» [4].

Важность находок А. А. Черновым угля на Севере становится понятной, если учесть, что в 1924 г. импорт каменного угля на Европейский Северо-Восток России составил 19,6 тыс. т (в 1912 г. - 49 тыс. т) [5]. Согласно данным главного геолого-разведочного Управления Высшего Совета Народного Хозяйства (BCHX), в начале 1930-хгг. общая потребность В каменном угле Европейского Севера

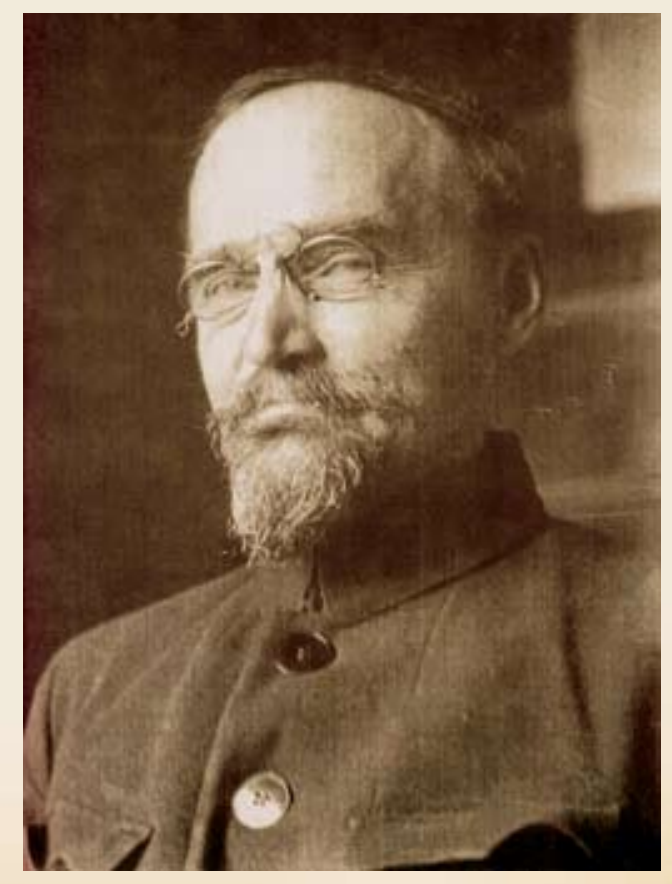

Первооткрыватель

Печорского угольного бассейна -

профессор Александр Александрович Чернов. Фото Г. А. Чернова, 1929 г.
России составляла 43-45 млн пудов, из них 1 млн пудов поставлялся из Донбасса, а остальное количество закупалось в Англии и на Шпицбергене [6].

Однако следует сказать, что в научных кругах предвидение А. А. Чернова встретило известное и вполне объяснимое недоверие. Сам ученый вспоминал: «...вы думаете, легко было доказать, что эти печорские угли имеют большое значение? Нет. Я помню, на первом заседании смеялись, что на Урале пермские угли. Нет таких. Там есть соль, гипс и т. д. По моему настоянию было созвано специальное совещание угольщиков, причем один очень почтенный специалист прямо заявил: «Вот чем нас заставляют заниматься, какими-то пермскими углями, которые не имеют никакой перспективы» [7]. Академик Д. В. Наливкин свидетельствовал, что научная дискуссия по этой проблеме была продолжительной по времени: «Я помню, как в начале 1930-х годов на заседании Ученого совета Геологического комитета (ныне ВСЕГЕИ) шел ожесточенный спор о значении Печорского бассейна. А. А. Чернов горячо доказывал его громадное значение. Его противник (уже не помню его фамилию) возражал, считая, что пласты угля здесь непостоянны, уголь плохого качества и запасы его незначительны. Время доказало справедливость выводов А. А. Чернова» [8].

Несмотря на полемику в научных кругах относительно Печорского угольного бассейна, в четвертом томе первого издания «Малой советской энциклопедии», подготовленного к печати в сентябре 1929 г., в статье, посвященной Автономной области Коми (Зырян), была помещена карта области, на которой район р. Косью был отмечен как центр крупных запасов ископаемого угля, что явилось очевидным признанием результатов поисковых работ А. А. Чернова [9].

Сразу же после обнаружения Г.А. Черновым в 1930 г. высококачественных коксующихся углей на р. Воркуте и проведения их лабораторного испытания был организован ряд совещаний у заместителя председателя ВСНХ В.И. Межлаука по проблеме промышленного освоения углей Печорского бассейна. По свидетельству А.А. Чернова, ход совещаний был следующим: «Сейчаспечорский уголь ставитсядляразработки вударном порядке, хотя мы - научные и практические деятели - предлагали бы несколько это дело отсрочить, потому что оно может завести нас в неприятное положение. У нас нет полей, подготовленных для эксплуатации, а постановка такая - добывать сейчас... На заседаниях у тов. Межлаука в ВСНХ была дана другая установка. Правительствоговорит: «За средствами дело не станет, нужно исходить из технических возможностей» [10]. 20 апреля 1931 г. ВCHX принял постановление «О развитии 
топливной базы в Северном крае», в котором предусматривалось заложить одну шахту в районе р. Воркуты и две-три в районе р. Адзьвы, чтобы в 1931 г. добыть в этих районах 7 тыс. т угля. Кроме того, в районе р. Нечи предполагалось заложить пробные угольные разрезы и добыть в 1931 г. здесь 2 тыс. т угля. Разведочные и добычные работы были возложены на Ухтинскую экспедицию ОГПУ. В 1931 г. Ухтинской экспедицией ОГПУ было добыто 9884 т угля, что составило $108,9 \%$ к плановому заданию [1].

27 марта 1932 г.было принято постановление Совета Труда и Обороны (СТО) № 286 «О развитии каменноугольной промышленности в районе бассейна р. Печоры», признававшее наличие значительных запасов каменного угля в Печорском бассейне и определявшее практические мероприятия по их промышленному освоению. 16 ноября 1932 г. постановлением СТО № 1423/423сс был создан Ухто-Печорский трест, которому было поручено вести разведку и эксплуатацию имеющих промышленное значение ископаемых Печорского бассейна и все связанные с этим работы.

26-28 января 1933 г. на заседании сектора природных ископаемых Госплана СССР с участием А. А. Чернова и других специалистов были заслушаны доклады геологов Н.Н. Тихоновича и Н. А. Кулика о результатах геологоразведочных работ треста в Печорском крае в 1929-1932 гг. В резолюции по докладам было констатировано: «Имеются значительные достижения в деле выявления полезных ископаемых ресурсов Печорского края, в результате коих край приобретает значительное народнохозяйственное значение» [11]. По мнению Госплана, в регионе к тому времени обозначились три пункта, развитие которых в ближайшие годы даст не менее 500 тыс. т угля и 100 тыс. т нефти. Ими были: Воркута и Пай-Хой (коксующиеся угли и полиметаллические руды), Ухта (нефть и асфальтиты) и Щугор (каменные угли).

Президиумом АН СССР в феврале 1935 г. была принята рабочая гипотеза народно-хозяйственного освоения Печорского края, в которой обосновывалась возможность добычи угля в Печорском бассейне в следующих объемах: 900 тыс. т — в 1937 г., 2 млн т - в 1942 г. [12].

Утрата Донбасса и Подмосковного угольного бассейна в годы Великой Отечественной войны привела к потере $60 \%$ имевшихся в СССР мощностей по добыче угля. Очевидно, что основное бремя компенсации выпавшей угледобычи Донбасса и Подмосковного угольного бассейна пришлось не на Печорский угольный бассейн. Однако дело не в абсолютных цифрах, а в том, что в воюющей стране образовался огромный дефицит угля. Следует добавить, что и угольные шахты Шпицбергена, снабжавшие Северный флот топливом, с началом войны были разрушены, а персонал был эвакуирован в Архангельск. Таким образом, Печорский угольный бассейн становился ответственным за снабжение углем Северного морского флота, Северной железной дороги, Печорского речного пароходства, блокадного Ленинграда [13], котельных европейского Севера СССР и других актуальных направлений использования угля.

К сожалению, этот вопрос в настоящее время в исторической литературе в достаточной мере не освещен. По данным ОАО «Воркутауголь», из 7,8 млн т угля, добытого на Воркутском месторождении в годы войны, около 6,3 млн т было отправлено за пределы Коми АССР, а в числе потребителей угля были девять областей и две автономные республики РСФСР, девять железных дорог, 35 городов, 52 предприятия, в том числе заводы:два военных, три танкостроительных, четыре авиационных, один автомобилестроительный, четыре резинотехнических, пять химических, один станкостроительный, один трубопрокатный, один сталелитейный и др. [14].

Таким образом, открытие А. А. Черновым Печорского угольного бассейна стало важной поворотной вехой в истории Коми АССР (ныне - Республика Коми), превратившей в кратчайшие сроки отсталую окраину России в поставщика топливно-энергетического сырья для нужд промышленности огромной страны.

И сегодня, несмотря на известные потрясения перестроечных лет, угледобывающие предприятия Воркуты и Инты работают в стабильном режиме. ОАО «Воркутауголь» является одной из крупнейших угледобывающих компаний России. Важными инвестиционными проектами в угольной отрасли Республики Коми являются подготовка к освоению и последующее строительство новых угольных шахт на Усинском месторождении [15].

\section{Список литературы}

1.Угольная сокровищница Севера.Сыктывкар, 1984. -312с.

2. Чернов А. А. Геологическая съемка Печорского края и проблема его недр // Материалы второй конференции по изучению производительных сил Северного края. Т. 1. Архангельск: Недра, 1933. - С. 16-36.

3. Архангельская губерния //Сб. ст. Вып. №1: Материалы по вопросу о колонизации и внутреннем расселении СевероВосточной области - Архангельск: Обл. и Арх. губ. плановые комис. - 1925. - 139 с.

4. К первой конференции по изучению производительных сил и народного хозяйства Северо-Восточной области и ко второму Областному краеведческому съезду - Архангельск: Центр. тип. Обл. план. комис. - 1925. - 24 с.

5. СССР по районам. Северо-Восточная область / Сост. М.И. Ивановский. М. -Л.: Гос. изд., 1926. - 99 с.

6. Волков М. С. Ископаемые угли бассейна р. Печоры / Труды Главного геолого-разведочного управления ВСНХ СССР. Вып. 18. - М. -Л.: 1931. - 30 с.

7. Материалы совещания по итогам геологических и геологоразведочных работ, проведенных различными организациями на территории Коми АССР за период 1948-1953 гг. / Отв. ред. А. А. Чернов. — Сыктывкар: 1955. - 404 с.

8. Наливкин Д. В. Наши первые женщины-геологи. - Л.: Наука, 1979. - 216 с.

9. Малая советская энциклопедия. 1-е изд. - Т. 4 / Гл. ред. Н.Л. Мещеряков. М.: 1931. - 957 с.

10. Материалы второй конференции по изучению производительных сил Северного края / Под ред. М.Я. Рознера - Архангельск: Недра 1933. - Т. 1. - 128 с.

11. Результаты геолого-разведочных работ в Ухто-Печорском районе и на о. Вайгач (1929-1932 г.) - Чибью: 1934. - 96 с.

12. Иевлев А.А., Асхабов А. М. Предыстория образования Института геологии Коми научного центра УрО РАН — Сыктывкар: 2013. - 92 c.

13. Уголь и торф Урала / Под ред. И. В. Дементьева. - Екатеринбург:Уральский государственный горный университет, 2007. - 705 c.

14. Воркутауголь / Под ред. В.И. Давыдова - Сыктывкар: 2001. - 168 c.

15. Самоделкин А. Н. Печорский угольный бассейн - потенциал роста // Освоение минеральных ресурсов Европейского Севера России / Сборник докладов V Северного инвестиционного форума - Сыктывкар: 2013. - С. 17-19. 


\section{Зарубежная панорама}

\section{ОТ РЕДАКЦИИ}

\section{Вниманию читателей предлагается \\ публикация из материалов «Зарубежные новости» - выn. № 260 - 267.}

\section{ОТ ЗАО «РОСИНФОРМУГОЛЬ»}

\section{Зарубежные новости}

\section{http: //www.rosugol.ru}

Более полная и оперативная информация по различным вопросам состояния и перспектив развития мировой угольной промышленности, а также по международному сотрудничеству в отрасли представлена в выпусках "Зарубежные новости", подготовленных $3 А О$ «Росинформуголь» и выходящих ежемесячно на отраслевом портале «Российский уголь» (www.rosugol.ru).

Информационные обзоры новостей в мировой угольной отрасли выходят периодически, не реже одного раза в месяц. Подписка производится через электронную систему заказа услуг.

По желанию пользователя возможно получение выпусков по электронной почте. По интересующим вас вопросам обращаться по тел.: +7(495) 723-75-25, e-mail: market@rosugol.ru -

отдел маркетинга и реализации услуг.

\section{ПЕРСПЕКТИВА ДОБЫЧИ МЕТАНА B KАЗАХСТАНЕ}

Перспективу добычи метана из угольных пластов обсудили в Астане. В ходе круглого стола на тему перспектив развития разведки и добычи метана из угольных пластов Карагандинского угольного бассейна заместитель акима Карагандинской области Ануар Ахметжанов отметил: «При реализации оптимистического сценария потребуется выявить потребителя, а технические возможности позволяют добывать до 4 миллиардов кубических метров в год, то есть всю Караганду, Карагандинскую область и Астану мы могли бы обеспечить собственным газом». По его словам, предположительно, себестоимость газа составит порядка 120 дол. США за 1 тыс. куб. м.

\section{ГЛОБАЛЬНОЕ ПОТЕПЛЕНИЕ УГРОЖАЕТ РЫНКУ УГЛЯ}

В июне 2013 г. президент США Барак Обама заявил, что правительство больше не будет финансировать зарубежные проекты по добыче и производству угля через U.S. Export-Import Bank. Затем Всемирный банк и Европейский инвестиционный банк отказались от таких проектов. Всего за последние 5 лет банки вложили в сектор более 10 млрддол. США. Эксперты отмечают, что шансов на рост частных инвестиций в секторе очень мало.

На фоне ужесточения экологических норм в США, увеличения субсидирования проектов по возобновляемым природным ресурсам и снижения цены на природный газ большое значение приобрел спрос на уголь в развивающихся странах. Тем не менее вряд ли сокращение поддержки банков будет иметь прямое влияние на Китай, но может сдержать развитие угольных проектов в Южной Африке и Вьетнаме и нанесет прямой ущерб таким компаниям, как Peabody Energy и Alpha Natural Resources.

Кроме этого, сейчас усиливается негативное отношению к углю в обществе, чего не было зафиксировано ранее. При сжигании угля выделяется очень большой объем углекислого газа, и ученые связывают глобальное потепление именно с выбросами этого газа. С другой стороны, сторонники этого источника топлива настаивают, что это один из немногих приемлемых способов для бедных стран, который позволяет обеспечивать население электроэнергией и теплом.

Фактически резкое сокращение угольных проектов может оставить миллионы людей без электричества. В Управлении энергетической информации США ожидают, что потребление угля в мире увеличится на треть до 200 квадриллионов британских тепловых единиц в год к 2040 г., так как вырастет потребление в развивающихся странах.

«Добычагаза, особенностигазаметано-угольныхпластов - этовысокозатратный бизнес, который требует больших вложений. В этой связи потребуется соответствующая господдержка: таможенные и налоговые преференции», - отметил заместитель акима. Он перечислил основные необходимые меры господдержки для успешного освоения угольного метана в Карагандинском угольном бассейне.

«Метан угольных пластов законодательно определить как самостоятельное полезное ископаемое иутвердитьдлянего специальный налоговый режим; предусмотреть меры законодательной и финансовой поддержки инициативы компаний, направленной на добычу и утилизацию метана угольных месторождений; проведение разведки с подсчетом запаса метана на перспективных участках за счет бюджетных средств, заблаговременную разработку уполномоченными органами совместно с недропользователями четких требований, обеспечивающих снижение экологического ущерба», - сказал он.

Кроме того, по словам Ахметжанова, необходимо предусмотреть законодательные ограничения по ведению горных работ по высокогазоносным выбросоопасным пластам без проведения заблаговременной дегазации непосредственно угольного пласта через скважины с поверхности; упростить процедуры по оформлению права недропользования, а также организовать обучение и стажировки местных кадров за рубежом по программам извлечения угольного метана. 


\section{УЗБЕКИСТАН НА РАЗВИТИЕ УГОЛЬНОЙ \\ ПРОМЫШЛЕННОСТИ НАПРАВИТ \\ СВЫШЕ 555 МЛН ДОЛ. США}

В Узбекистане активно идут процессы модернизации и технологического переоснащения различных отраслей промышленности. Не осталась в стороне и угольная промышленность, от которой во многом зависит энергетическая безопасность государства, ведь основным потребителем ее продукции выступает отечественный электроэнергетический сектор.

В июне 2013 г. была утверждена Программа модернизации, технического и технологического перевооружения предприятий угольной промышленности и ее сбалансированного развития на период 2013-2018 гг. общей стоимостью свыше 555 млн дол. США. Ее финансирование планируется осуществлять за счет средств Фонда технического перевооружения и модернизации угольной отрасли, «Узбекугля», а также кредитов коммерческих банков.

Особое внимание в рамках программы уделено модернизации угледобывающих мощностей и развитию транспортной инфраструктуры. В частности, крупнейшим проектом станет технологическое обновление производства ОАО «Шаргунькумир». На эти цели планируется направить свыше 334 млндол. США. Уже в будущем году предусматривается начать работы по строительству нового разреза «Апартак». В перспективе это позволит значительно увеличить объемы производства угля. При этом отметим, что по итогам шести месяцев 2013 г. угольщики добыли свыше 2,67 млн т угля и превысили прогнозные показатели на 1,8\%.

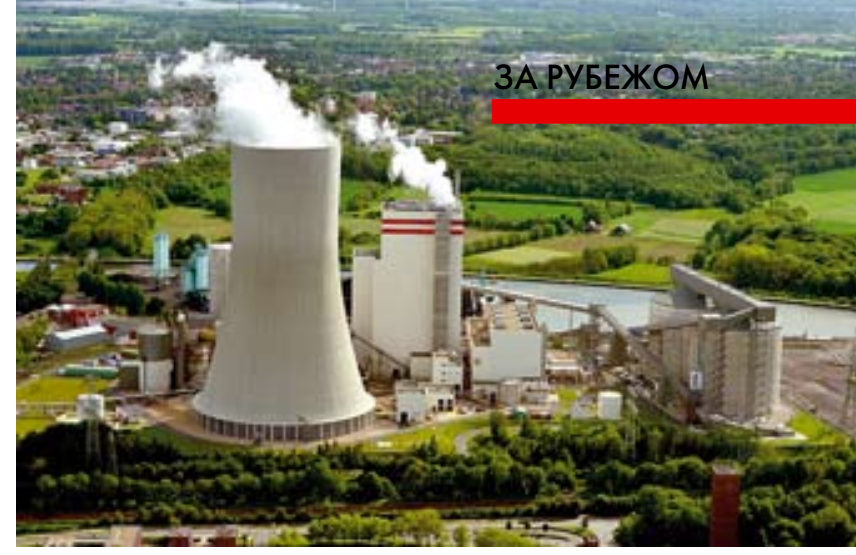

\section{САМАЯ ЭФФЕКТИВНАЯ УГОЛЬНАЯ ЭЛЕКТРОСТАНЦИЯ НАХОДИТСЯ В ГЕРМАНИИ}

Электростанция Lbnen принадлежит компаниям Trianel Kohlkraftwerk Lbnen GmbH и Co. KG, имеет КПД 45,95\%. На ТЭС установлен одинединственный энергоблок электрической мощностью 750 МВт. Строительство электростанции велось с августа 2008 г. в рамках соглашения между компаниями-собственниками и корпорацией Siemens. Стоимость новой ТЭС составляет около 1,4 млрд евро.

На ТЭС Lьnen установлено современное оборудование компании Siemens: паровая турбина SST5-6000, электрический генератор SGen5$3000 \mathrm{~W}$, а также набор приборов измерения и АСУТП SPPA-Т3000. Электростанция предназначена для несения базовых нагрузок.

\section{В КИТАЕ ПРОИЗОШЕЛ КРУПНЫЙ КОРРУПЦИОННЫЙ СКАНДАЛ}

Угольная шахта в китайском городе Чжунше уходит вглубь земли почти на 1 км. Эта шахта и еще две в провинции Шаньси в Северном Китае оказались в центре необычного для Китая скандала: государственный конгломерат China Resources, купивший их, обвиняют в коррупции и бесхозяйственности, пишет The New York Times.

Проблемы China Resources начались в 2010 г. — компания согласилась заплатить 1,6 млрддол. США за три угольные шахты и связанные с ними активы. Продавцом шахт стал бизнесмен Чжан Зинмин. Он пользуется репутацией удачливого спекулянта, а не серьезного бизнесмена. Он получил $20 \%$ в новом совместном предприятии.

China Resources должна была получить доступ к добыче угля в Шаньси, которая является центром угольной промышленности уже больше века. Шахты расположены в непосредственной близости от потенциальных покупателей. Однако с момента покупки государственный гигант так и не начал добывать уголь. Теперь руководство конгломерата обвиняют в коррупции. Документы о сделке и судебном деле, которое ведется в Гонконге, попали в прессу. Они пролили свет на обычно скрытую деятельность крупных китайских государственных корпораций.

Возможно, китайская экономика и ресурсы страны просто стали заложниками корпораций и их руководства, которое имеет значительное политическое влияние и может получить доступ к дешевым кредитам.
«Несмотря на трудности, обусловленные особыми условиями лицензирования для угольныхэлектростанций германии, мы сумели построить ТЭС по самым высоким техническим стандартам на сегодняшний день» - рассказал генеральный директор Energy Solutions, подразделения Siemens Energy Райнер Хэеншилд.

Владельцы электростанции ожидают, что TЭC Lbnen в 2014 г. сможет проработать 7000 часов с полной нагрузкой. По оценкам экспертов, по сравнению со старыми угольными ТЭС новая ТЭC Lьnen благодаря современным очистным технологиям позволит снизить выбросы $\mathrm{CO}_{2}$ на 1 млн т вгод.

\section{ИМПОРТ УГЛЯ В ТУРЦИЮ ВЫРОС НА $6 \%$}

Турция в январе-октябре 2013 г. по сравнению с аналогичным периодом 2012 г. увеличила импорт коксующегося угля на 6,08\%. Об этом свидетельствуют данные статистики. Поставки продукции в страну достигли в указанный период 4,13 млн т.

Напомним, что Турция в сентябре 2013 г. по сравнению с сентябрем 2012 г. увеличила импорт коксующегося угля более чем в два раза, до 491,886 тыс. т. По сравнению с предыдущим месяцем поставки продукции выросли практически в три раза. В целом по итогам января-сентября 2013 г. по сравнению с аналогичным периодом минувшего года импорт коксующегося угля в Турцию поднялся на 15,46\%, до 3,9 млн т. Ранее сообщалось, что Турция в июле 2013 г. по сравнению с июлем 2012 г. увеличила импорт коксующегося угля на $34 \%$, до 2,76 млн т. Годом ранее поставки оценивались в 2,08 млн т. Тем не менее по сравнению с предыдущим месяцем импорт уменьшился на $28 \%$. 


\section{SHERRITT УХОДИТ ИЗ УГОЛЬНОГО БИЗНЕСА}

Канадская энергокомпания, работающая в горнодобывающей промышленности, Sherritt International Corp, приняла решение продать часть своих активов, в том числе весь угольный бизнес, стоимость которого оценивается в 946 млн канадских дол. (891 млндол. США). После продажи угольных активов Sherritt планирует сосредоточиться на добыче никеля и нефти.

Группа во главе с Altius Minerals Corp согласилась приобрести угольный бизнес Sherritt, а также часть активов горной промышленности за 481 млн канадскихдол., которые будут уплачены наличными деньгами. Об этом сообщили представители Sherritt International Corp в Торонто. Кроме того, компания Westmoreland Coal Co приобретет некоторые угольные шахты Sherritt за 312 млн канадскихдол. Также рассматривается вариант заключения договоров долгосрочной аренды шахт, оцененных в 153 млн канадских дол. На фоне новостей о продаже активов акции Sherritt International Corp выросли в цене на 14,79\%.

\section{МИРОВЫЕ ТРЕНДЫ УГЛЯ}

Уже очевидно, что энергетические ресурсы нашей планеты исчерпаемы. Полагают, что запасов нефти хватит примерно на 40 лет, а природного газа - на 65 лет. И только запасы каменного угля позволят получать энергию примерно 400 лет. В то же время мировое потребление энергии неуклонно возрастает. По Сценарию новых стратегий (World Energy Outlook2012) от International Energy Agency (IEA), мировой спрос на энергоресурсы увеличится более чем на треть за период до 2035 г., причем $60 \%$ этого роста придется на Китай, Индию и Ближний Восток.

Одновременно мировой рынок энергоносителей подвержен влиянию многочисленных взаимосвязанных факторов. Это и торможение мировой экономики, и усиление напряженности в «дуге нестабильности», и ценовое давление американского сланцевого газа, и даже климатические катаклизмы. Все эти разновекторные факторы оказывают существенное влияние на конъюнктуру мирового рынка энергоносителей.

Причем взаимовлияние между рынками и ценами на различные виды топлива усиливается. Согласно оценке IEA, если взять за базу минимальную цену американского газа в 2012 г., то она составляет $20 \%$ от уровня импортных цен в Европе и 12,5\% - в Японии. В результате поддавлением дешевого газа на рынке США американский уголь, в свою очередь, будет оказывать давление на рынок газа Европы. В структуре мирового экспорта энергоносителей уголь уверенно занимает четвертое место с долей 3,9\% (2012) в стоимостном измерении после сырой нефти (50,6\%), нефтепродуктов (29,8\%) и природного газа $(12,7 \%)$ (International Trade Centre - ITC).

Динамика его мирового экспорта в 2008-2012 гг. характеризовалась повышательным трендом, что свидетельствует о его непреходящей востребованности мировой промышленностью. За это время стоимость экспорта угля увеличилась с 94,8 до 128,8 млрд USD, или на $35,8 \%$, а доля данного товара в мировом экспорте колебалась в диапазоне от 3,4до 4,7\% (USD).

Основными игроками мирового рынка угля являются Индонезия, Австралия, Россия, США и ЮАР. На долю этих

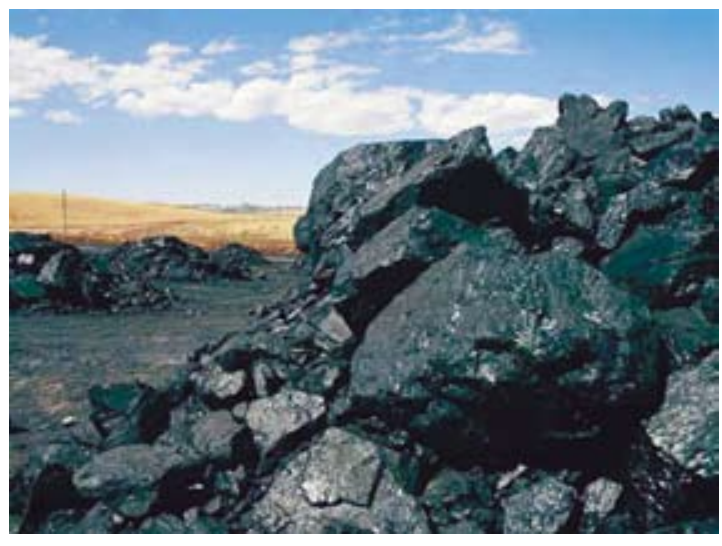

\section{КИРГИЗИЯ ПЛАНИРУЕТ \\ ЭКСПОРТИРОВАТЬ СВОЙ УГОЛЬ В УЗБЕКИСТАН И КИТАЙ}

Правительство КР ведет переговоры с Узбекистаном по поставке угля из Кыргызстана. Об этом сообщил журналистам генеральный директор государственного предприятия «Кыргыз комур» Нарынбек Сатыбалдиев. Как рассказал глава данного угольного предприятия, в ноябре 2013 г. во время визита премьерминистра КР Жанторо Сатыбалдиева в Узбекистан, кыргызской стороной было предложено начать поставлять уголь из Кыргызстана. По словам г-на Сатыбалдиева, отпускная цена на твердое топливо предложена по цене 40 дол. за 1 т.

«В этом направлении сейчас ведутся переговоры. Также ведутся переговоры с Китаем по этомужевопросу, нопока только на начальной стадии», - отметил он.

Сегодня в целом по республике отпускные цены на уголь на топливных пунктах для населения варьируются в пределах от 23 до 180 дол. США. Нарынбек Сатыбалдиев подчеркнул необходимость как можно в краткий срок начать самостоятельно обеспечивать кыргызстанцев отечественным углем, по его мнению, это позволит населению страны использовать качественное и дешевое твердое топливо.

пяти стран в 2012 г. пришлось 79,5 \% мирового экспорта угля в тоннаже. О высокой концентрации угольного бизнеса свидетельствует то, что на долю первых десяти стран-экспортеров из 95 приходится 94,6\% экспортных поставок данного товара.

Впечатляет картина мирового импорта угля. Среди покупателей данного товара в 2012 г. - 163 страны. Крупнейшие из них - Китай, Япония, Республика Корея и Индия, суммарная доля которых составляет $57,8 \%$ в тоннаже. Следует отметить, что на 20 крупнейших покупателей приходится 91,5\% мировых закупок угля. Украина в данном рейтинге находится на 16-м месте с долей 1,3\%.

На 15-м месте - крупнейшая страна Латинской Америки Бразилия (1,5\%), а на 17-м - один из азиатских тигров - Гонконг (1,1\%). Индикатором темпов развития экономики страны является потребление энергоносителей, в частности угля. К примеру, за период с 2008 по 2012 г. импорт угля Китаем увеличился в 5,8 раза в тоннаже, Малайзией - в 2,5 раза, Индией - в 2,1 раза и Таиландом - в 2 раза. 


\section{Оцени новый уровень производительности}

Горный экскаватор: R 9350

- Высокие усилия отрыва и резания

- Объем ковша от 15-20 м

- Короткие рабочие циклы благодаря системе электронного контроля

- Доступен в арктическом, высокогорном и электрическом исполнениях
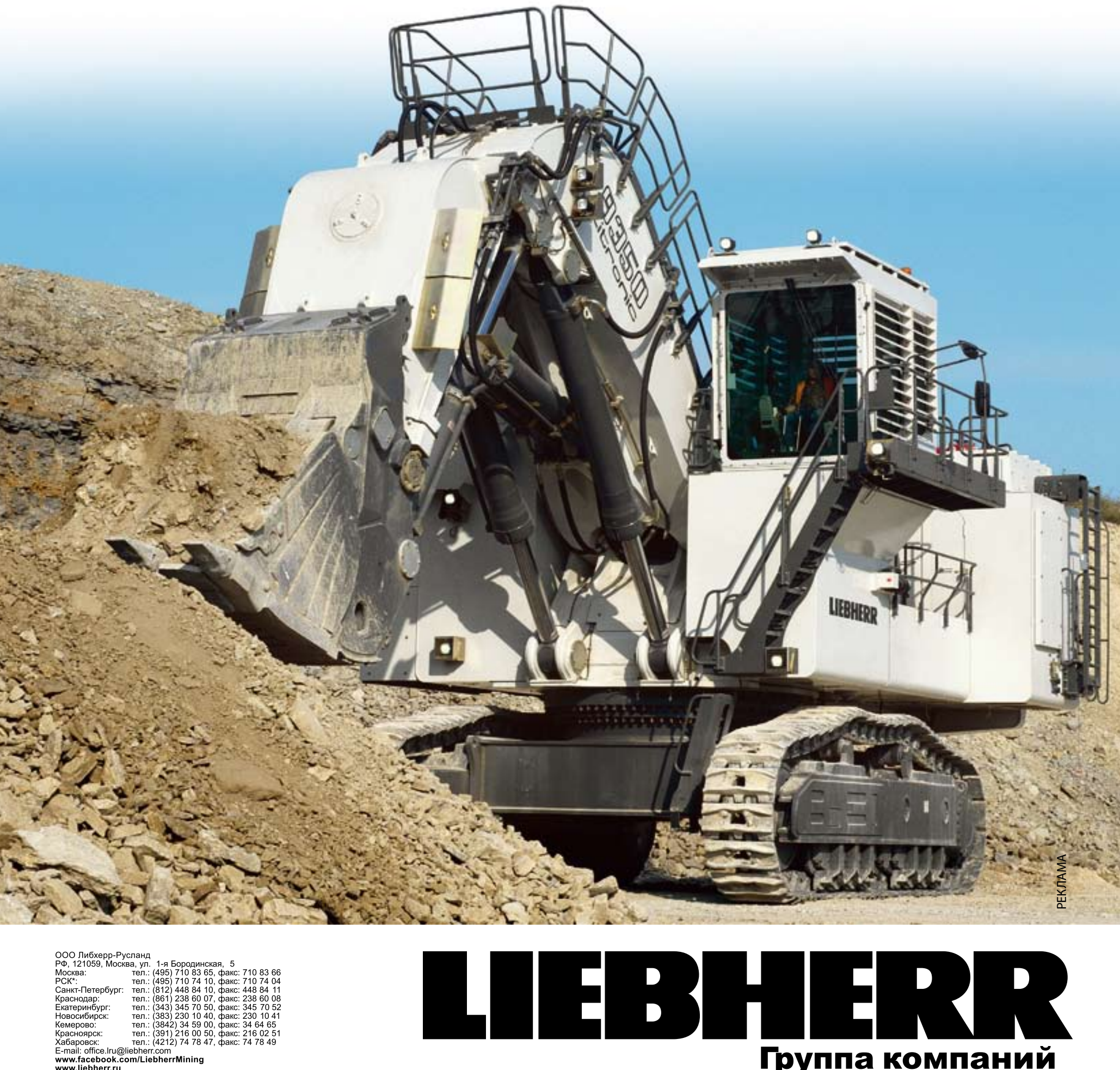
Надёжное и безопасное

транспортное средство в шахте
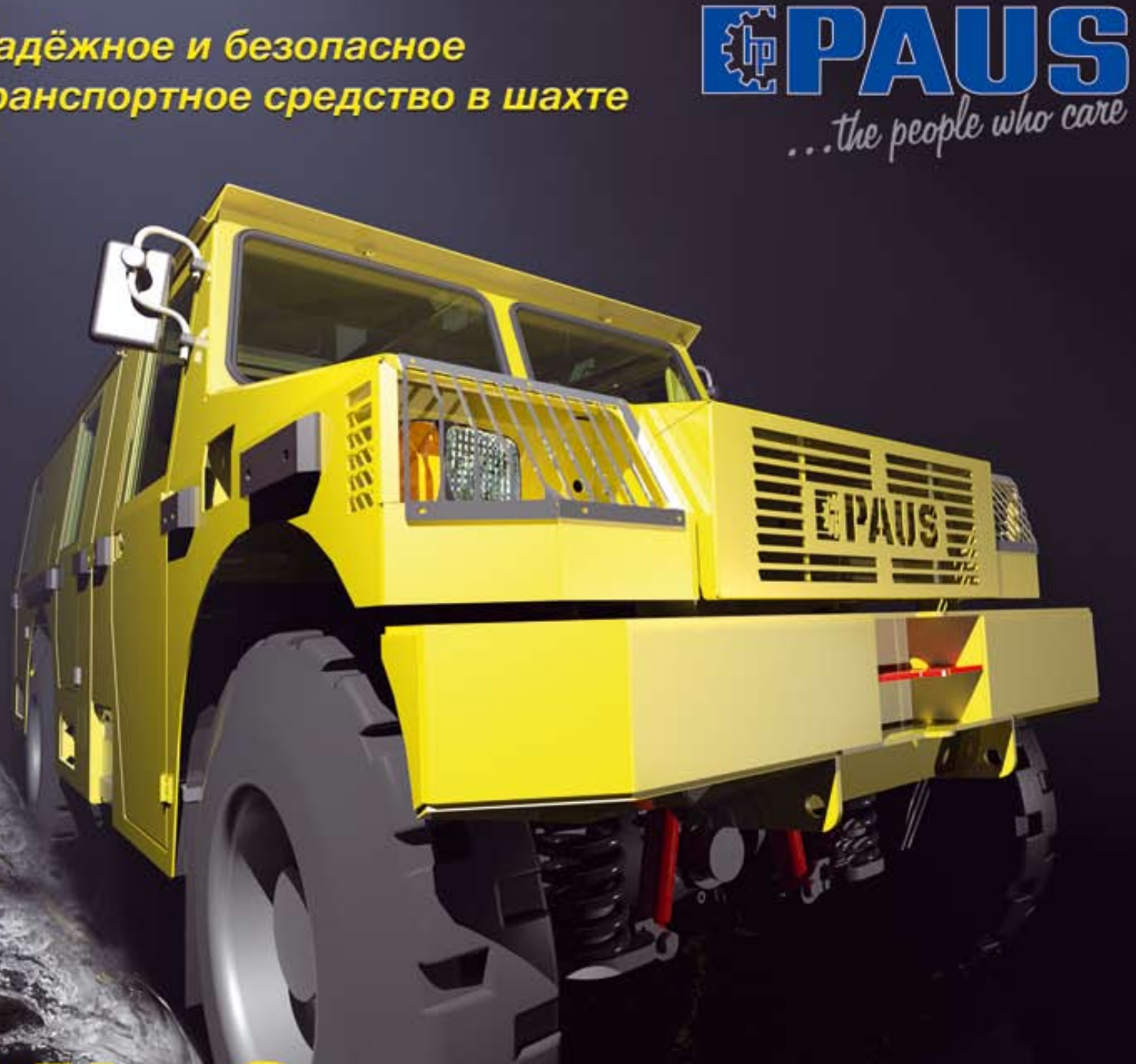

Non
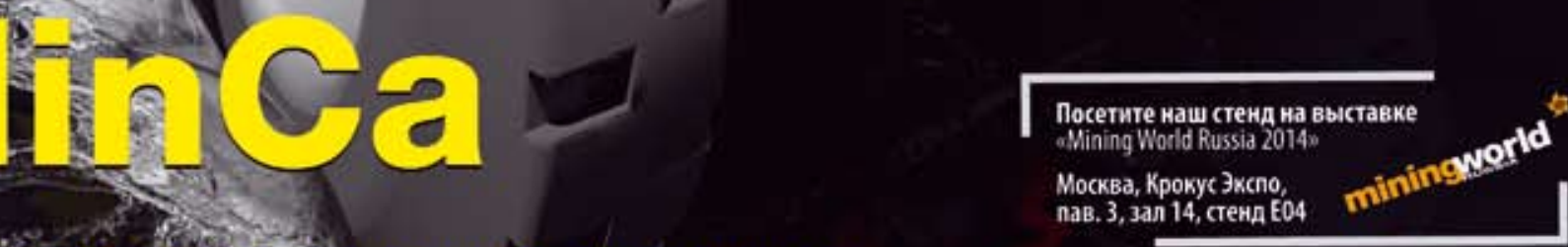

Разработал аядля максимально сложныхусловий в шахте

$>$ Грузопбоъемность -4 тонны

Посетите наш стенд на выставке yronь России и Майнин 2014

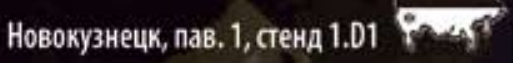

$>$ чрезвычайно манёвренная

> В стандартном и взрывозащищенном исполнении

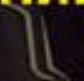

000 «ПАУС

115054 , г. Москва'

ул. Дубининская, А. 57, стр. 1А, оф. 105

Тел.: +7 (495) 783-21-19

E-mail: info@paus.ru

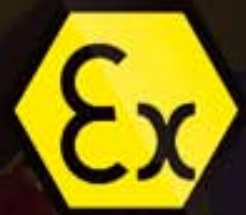

